
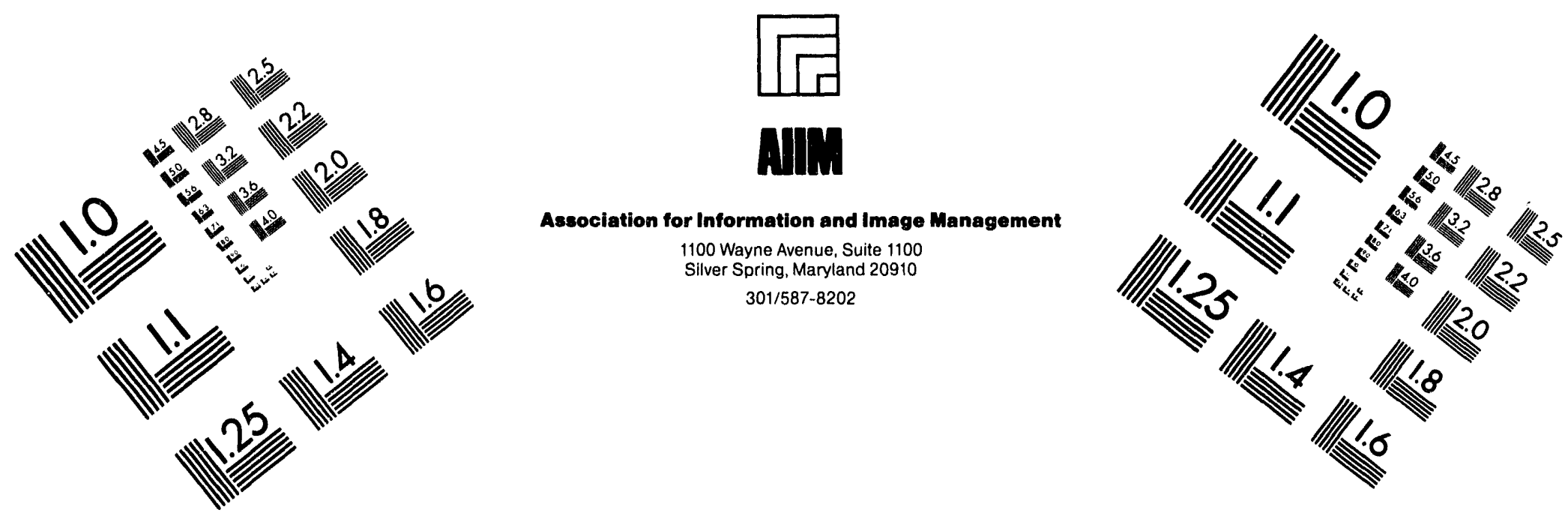

\title{
Centimeter
}

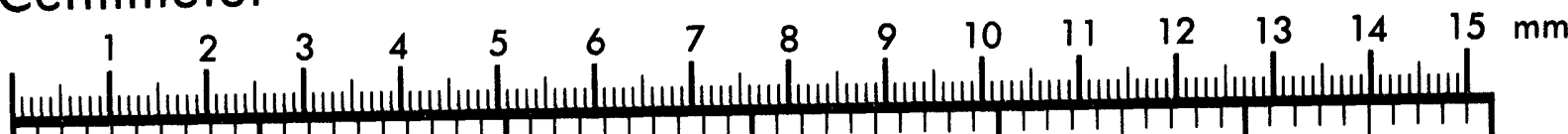

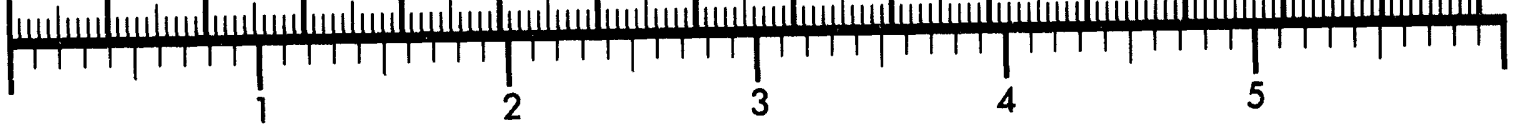
Inches
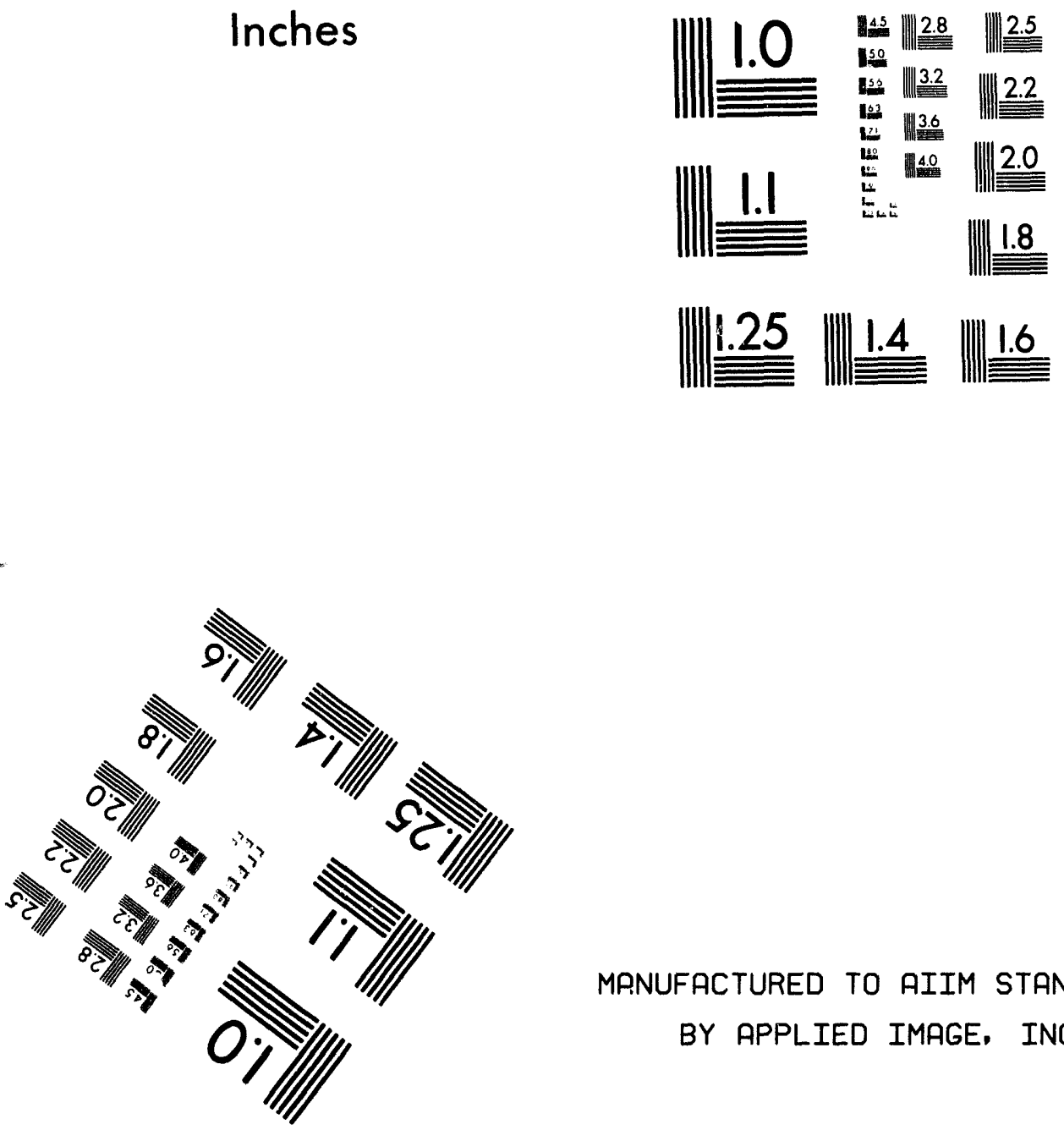

MPNUFACTURED TO AIIM STANDARDS

BY APPLIED IMAGE, INC.

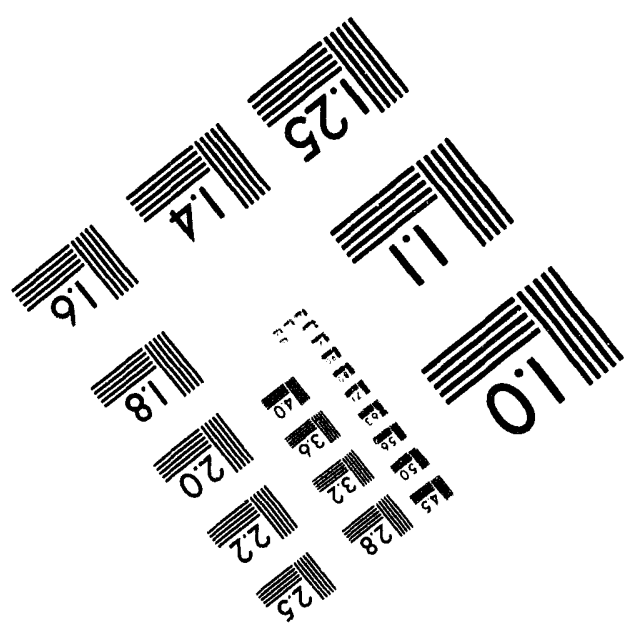



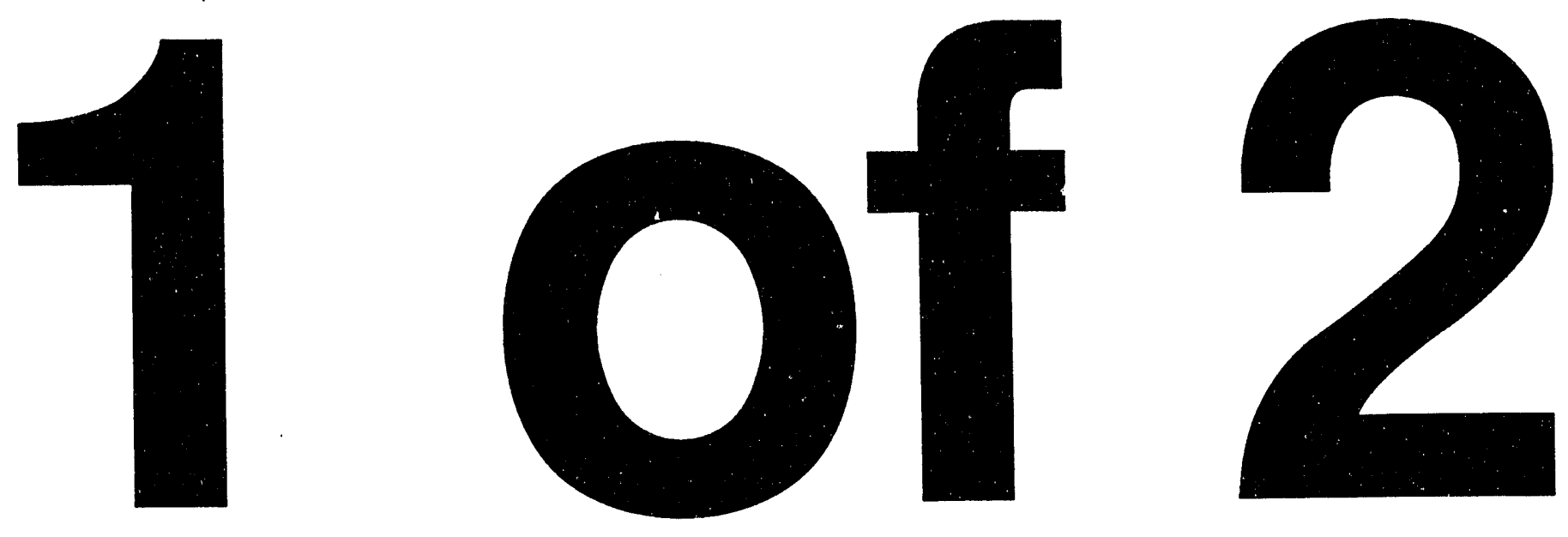
INTENSIVE ARCHAEOLOGICAL SURVEY OF THE PROPOSED SAVANNAH RIVER ECOLOGY LABORATORY CONFERENCE CENTER AND EDUCATIONAL FACILITY, SA VANNAH RIVER SITE, AIKEN COUNTY, SOUTH CAROLINA

Keith Stephenson

David Colin Crass

Kenneth E. Sassaman

SAVANNAH RIVER ARCHAEOLOGICAL RESEARCH PROGRAM SOUTH CAROLINA INSTITUTE OF ARCHAEOLOGY AND ANTHROPOLOGY UNIVERSITY OF SOUTH CAROLINA

Technical Report Series Number 17

February 1993
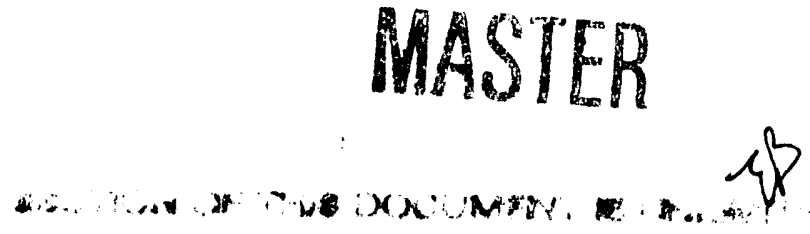


\title{
INTENSIVE ARCHAEOLOGICAL SURVEY OF THE PROPOSED \\ SA VANNAH RIVER ECOLOGY LABORATORY \\ CONFERENCE CENTER AND EDUCATIONAL FACILITY, SAVANNAH RIVER SITE, AIKEN COUNTY, SOUTH CAROLINA
}

\author{
Keith Stephenson \\ David Colin Crass \\ Kenneth E. Sassaman
}

This study was conducted through funding provided by the United States Department of Energy under contract number DE-FCO9-88SR15199.

This study was prepared as an account of work sponsored by the United States Government. Neither the United States nor the United States Department of Energy, nor their employees, nor any of their contractors, subcontractors, or their employees, make any warranty for the accuracy, completeness, or usefulness of any information, apparatus, product or process disclosed, or represent that its use would not infringe privately-owned rights.

SAVANNAH RIVER ARCHAEOLOGICAL RESEARCH PROGRAM SOUTH CAROLINA INSTTTUTE OF ARCHAEOLOGY AND ANTHROPOLOGY UNIVERSITY OF SOUTH CAROLINA

Technical Report Series Number 17 February 1993 


\section{MANAGEMENT SUMMARY}

Archaeological investigations of the 70-acre parcel allocated for the Savannah River Ecology Laboratory (SREL) Conference Center and Educational Facility on the Savannah River Site entailed intensive subsurface testing to delineate the boundaries of two previously recorded sites, 38AK289 and 38AK287, located within the project area. Both of the sites have the potential to yield significant data on the prehistoric and historic period occupations of the Aiken Plateau and are thus considered eligible for nomination to the National Register of Historic Places (NRHP). The Savannah River Archaeological Research Program (SRARP) recommends that adverse effects to sites 38AK289 and $38 \mathrm{AK} 287$ from proposed construction be mitigated through avoidance. In consultation with SREL personnel, construction within the site boundaries of 38AK289 has already been redesigned to avoid impacts to significant components of the site. In short, the relocated building footprint will altogether avoid components situated within the upper 70 cm of site deposits. Ephemeral Early Archaic (ca. 9500-8000 B.P.) deposits within 38 AK289 are located in the building footprint at a depth range of $70-100 \mathrm{~cm}$ below surface. Because these ccnsist of low-density artifact assemblages that are duplicated by similar assemblages in portions of the project area that will be undisturbed, the proposed construction will have no adverse effect on 38AK289. Site 38AK287 is located in the proposed utility right-of-way and can be completely avoided by either spanning the site with an aerial transmission line or by diverting the right-of-way slightly if a subsurface line is desired.

A third site, 38AK466, was discovered through survey in the project area and tested to evaluate its archaeological significance. Because it consists of limited and disturbed surficial deposits of unknown prehistoric and twentieth-century affiliation, $38 A K 466$ is not considered eligible for nomination to the NRHP. The SRARP recommends a determination of no effect to 38AK466 from construction of the SREL Conference Center and Educational Facility.

Archaeological investigations within the original (and subsequently altered) project area involved previously recorded sites 38AK288, 38AK274, 38AK282, and 38AK283. These four sites lie outside the revised project area and will not be affected by proposed construction activities. Nevertheless, the report includes full documentation of the investigations conducted at these sites. 


\section{ACKNOWLEDGEMENTS}

Bob Nestor and Jerry Garvin of the Savannah River Ecology Lab consulted with SRARP personnel on several occasions to ensure coordination and cooperation between the archaeologists and project planners. Their efforts in this capacity are gratefully acknowledged. Katherine Richardson of Heritage Preservation Associates conducted much of the archival research reported herein. Additional input on matters of history and historical archaeology was provided by SRARP Co-Program Manger Richard Brooks, who also arranged for the archival research and provided administrative support for the project. SRARP Co-Program Manager Mark Brooks lent his geoarchaeological and editorial expertise to the project. A field crew consisting of Tina Monaco, Tammy Forehand, and Chris Gillam did an admirable job dealing with the many changes in strategy they had to endure. We thank Charlie Davis of SREL for lending an occasional hand in the field. Most of the fine computer graphics in this report were produced by Chris Gillam. Finally, we thank Andrew Grainger of DOE-Environmental Division for his assistance in negotiating with SREL and for his overall administrative support for this project. 


\section{TABLE OF CONTENTS}

Management Summary .......................................................................................................ii

Acknowledgement ……................................................................................................... iv

List of Figures ...................................................................................................................... vi

List of Tables ..................................................................................................................... viii

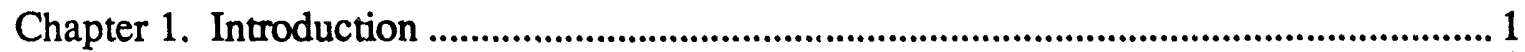

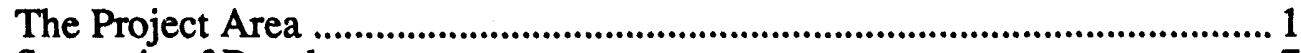

Synopsis of Results .........................................................................................

Chapter 2. Environmental, Archaeological, and Historic Contexts ...................................9

Environment and Prehistoric Settlement Patterns.......................................... 9

Historic Period Settlement ....................................................................... 19

The Archival Record of Historic Period Occupation in the Study Area....... 20

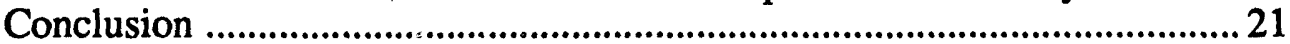

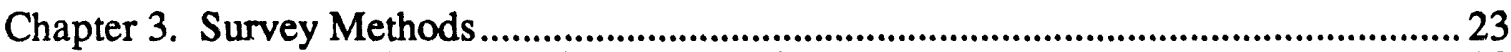

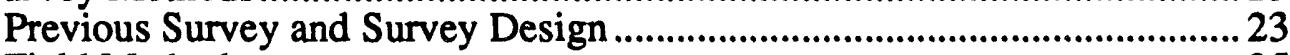

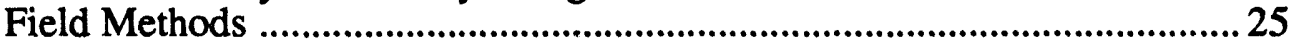

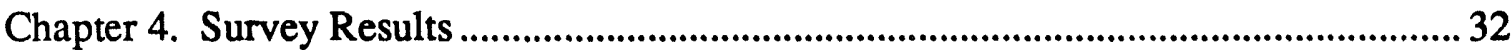

Sites Within the Area of Direct Impact.........................................................32

38AK289: Results of Field Investigations .................................................. 32

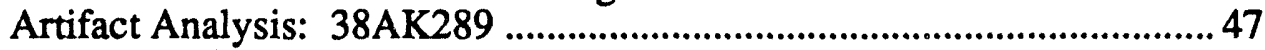

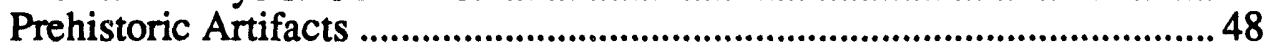

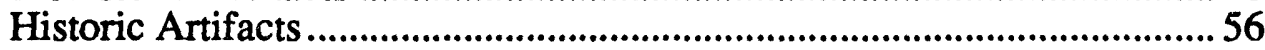

38AK287: Results of Field Investigations ...............................................57

Artifact Analysis: 38AK287 ....................................................................60

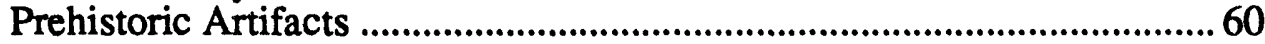

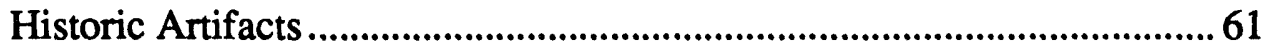

38AK466: Results of Field Investigations ...............................................62

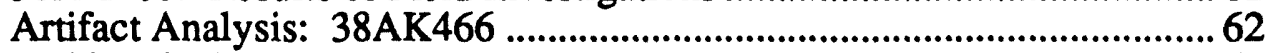

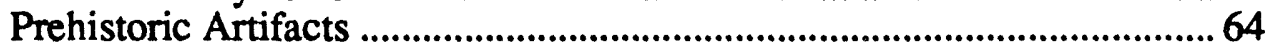

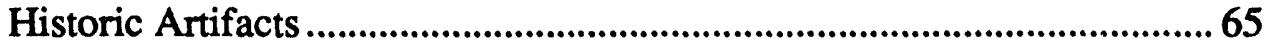

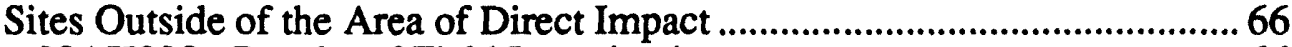

38AK288: Results of Field Investigations ..................................................6 66

Artifact Analysis: 38AK288 ………..........................................................6 66

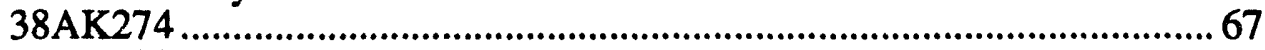

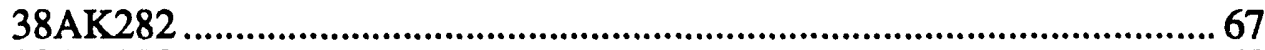

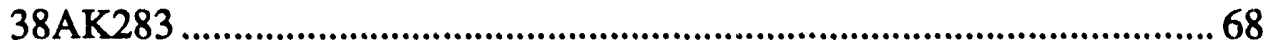

Summary and Conclusions...........................................................................6 68

Prehistoric Period Occupation Sequence and Site Use ................................6 68

Historic Period Occupation Sequence............................................................. 69

Chapter 5. Conclusions and Recommendations......................................................... 71

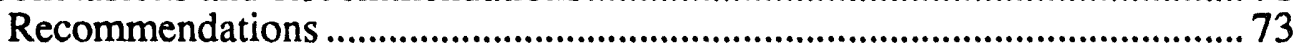

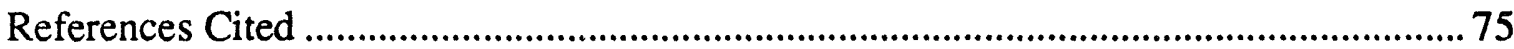


Appendix A. Provenience Data ................................................................................. 80

Appendix B. Artifact Inventory, 38AK289 ................................................................. 92

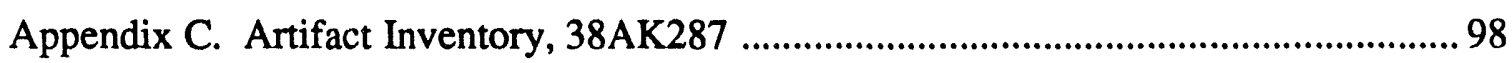

Appendix D. Prehistoric Ceramic Sherd Data .................................................................. 99

Appendix E. Hafted Biface Data.................................................................................... 101

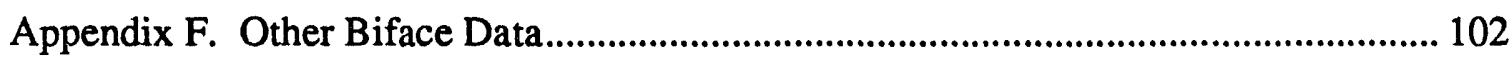

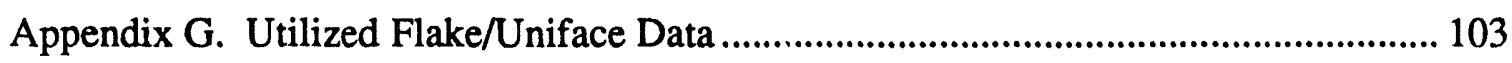

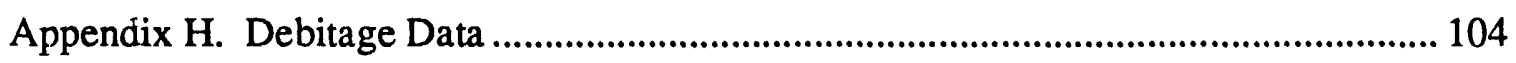

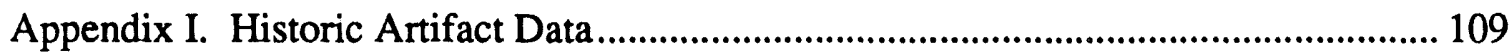




\section{LIST OF FIGURES}

Figure 1. Location of project area within Savannah River Site, South Carolina ............... 2

Figure 2. Topographic map of project area and relevant landmarks. ................................ 3

Figure 3. Current land-use in vicinity of project area. .................................................5

Figure 4. View of mature pine plantation in Stand 4. ................................................6

Figure 5. View of immature pine plantation in Stand 6............................................6

Figure 6. View of mixed pine-hardwood community in Stand 7.....................................7

Figure 7. Location of sites in and around project area on the New Ellenton (1965; photorevised 1971) and Windsor (1965) USGS 7.5 topographic quads. ...........................................................................8

Figure 8. Physiography of the Savannah River Site area.............................................. 10

Figure 9. Model of early to mid-Holocene prehistoric settlement in the Savannah River Site area.

Figure 10. Model of Late Archaic prehistoric settlement in the Savannah River Site area.

Figure 11. Model of Early Woodland prehistoric settlement in the Savannah River Site area.

Figure 12. Geographic relation of project area to the Savannah and South Fork Edisto rivers and associated tributaries.

Figure 13. Survey strata (PIU quadrants) of the project area and vicinity. 24

Figure 14. Archaeological Sensitivity Zones of the project area and vicinity. 24

Figure 15. Map of 38AK289 showing location of shovel test transects and test units.... 27

Figure 16. Location of shovel test Transect 18 in access road right-of-way of project area.

Figure 17. Locations of shovel test Transects 13, 14, and 22, and Provenience 11 along the origin location of utility easement.

Figure 18. Locations of shovel test Transects $26,27,28$, and 30 along the original and revised locations of utility easement.

Figure 19. West profile photograph, Provenience 14, 38AK289................................. 34

Figure 20. West profile drawing, Provenience 14, 38AK289 ................................... 35

Figure 21. Sketch map of "Club House" remains and Phelp's Pond, 38AK289. ............. 36

Figure 22. Architectural remains of "'Club House," 38AK289. .................................... 37 
Figure 23. Phelp's Pond and earthen dam, 38AK289.................................................... 37

Figure 24. Earthen dam and concrete flume, 38AK289. ................................................. 38

Figure 25. Primary spillway on located eastern end of Phelp's Pond dam, 38AK289.... 38

Figure 26. Location of shovel tests of Transect 25 in relocated footprint of Conference Center.

Figure 27. Northeast portion of 38AK289, showing locations of shovel tests, test units, and architectural remains of "Club House." 42

Figure 28. Cross-section of Feature 1, South Profile, Provenience 14, 38AK289. 44

Figure 29. Southeast portion of 38AK289, showing locations of shovel tests and test units in vicinity of historic period rock pile.

Figure 30. Western margin of 38AK289, showing locations of shovel tests excavated to delineate early historic occupation. 46

Figure 31. Shovel tests excavated in the north-central portion of 38AK289................... 47

Figure 32. Prehistoric ceramic sherds from sites in the project area. …............................ 50

Figure 33. Diagnostic hafted bifaces and unifaces from sites in the project area.............52

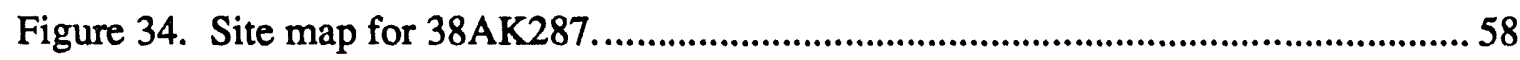

Figure 35. North profile drawing (top) and planview (bottom) of

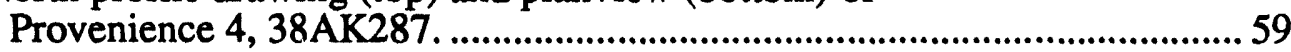

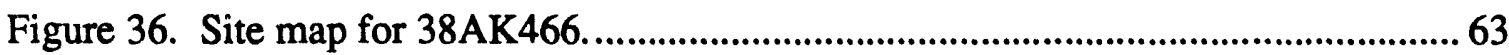

Figure 37. 1951 aerial photograph showing structure location at 38AK466....................64

Figure 38. Euro-American occupation sequence of the project area. ................................. 70 


\section{LIST OF TABLES}

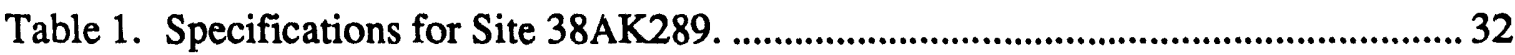

Table 2. Prehistoric Artifact Inventory by Provenience Type, 38AK289. ........................ 49

Table 3. Prehistoric Pottery Frequency by Type and Provenience Type, 38AK289. ...... 49

Table 4. Prehistoric Biface Frequency by Type and Provenience Type, 38AK289........ 51

Table 5. Uniface and Utilized Flake Frequency by Type and Provenience Type,

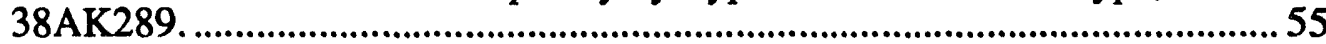

Table 6. Frequencies of Historic Artifacts by Analytical Class, 38AK289.......................56

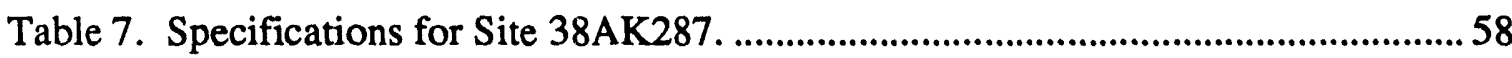

Table 8. Prehistoric Artifact Inventory by Provenience Type, 38AK287. ........................ 60

Table 9. Frequencies of Historic Artifacts by Analytical Class, 38AK287...................... 61

Table 10. Specifications for Site 38AK466. ......................................................................... 64

Table 11. Prehistoric Artifact Inventory by Provenience, 38AK466................................. 65

Table 12. Frequencies of Historic Artifacts by Analytical Class, 38AK466...................65

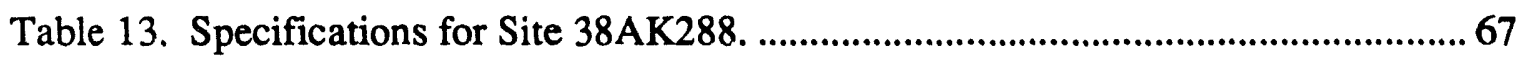

Table 14. Artifacts Recovered from 38AK288 by Shovel Test. ......................................... 67

Table 15. Artifactual Sources of Chronometric Data. ..........................................................69

Table 16. Evaluation and Recommendations for Sites Within the Proposed SREL Conference Center and Educational Facility. ..................................................... 71 


\section{CHAPTER 1 INTRODUCTION}

Documented in this report are the methods and results of an intensive archaeological survey for the proposed University of Georgia Savannah River Ecology Laboratory (SREL) Conference Center and Educational Facility on the United States Department of Energy's Savannah River Site (SRS), Aiken County, South Carolina (Figure 1). Archaeological investigations conducted by the Savannah River Archaeological Research Program (SRARP) on the 70-acre project area and associated rights-of-way consisted of subsurface testing at two previously recorded sites (38AK287 and $38 \mathrm{AK} 289$ ), and the discovery of one previously unrecorded site (38AK466). The results show that sites 38AK287 and 38AK289 contain archaeological remains that may yield significant information about human occupations in the Aiken Plateau and are therefore considered eligible for nomination to the National Register of Historic Places (NRHP). Adverse impacts to these sites can be mitigated through avoidance. In consultation with the SRARP, SREL personnel have already altered construction plans to avoid significant shallow deposits within 38AK289. Continued cooperation with the SREL is requested to avoid impacts to 38AK287. Significant archaeological deposits were not located at 38AK466, thus the site is not considered eligible for nomination to the NRHP and will not be adversely effected by proposed construction.

Four other sites (38AK288, 38AK274, 38AK282, 38AK283) in the original, and subsequently modified, project area received some archaeological attention early in the project. Although these resources will not be affected by proposed construction, this report includes full documentation of the field investigations conducted at the sites.

\section{The Project Area}

The proposed footprint for the SREL Conference Center and Educational Facility (hereafter referred to as Conference Center) and associated utility right-of-way was changed slightly over the course of archaeological investigations for the project. The original proposal to construct and operate a Conference Center on the SRS was issued in an SR-88 Site Use Application (SU-91-89-C) in August 1991. The Site Use Application process is an effective system of land-use coordination among the various agencies on the SRS. Accompanying the application was a brief description of the project area location, size, and present land usage. In addition, an Environmental Assessment (US DOE 1992) contained detailed information regarding the environmental consequences associated with the construction and operation of a conference center on the SRS. The following information regarding the Conference Center project is summarized from these two documents.

The project area encompasses an approximately 70 -acre (28.3 ha) tract of land on the northern periphery of the SRS, near the western margin of Upper Three Runs Creek at its confluence with Boggy Gut Branch (Figure 2). The project boundary includes two right-of-way easements, one for the purpose of an access road and the other for a utility corridor. In proximity to the project area is an historic period pond that is connected to Upper Three Runs Creek by a small, unnamed stream. Locally known as Phelps Pond, it is two acres in size and contained by an earthen dam.

The western extent of the project area fronts Phelps Road (SRS 781-3) approximately $1400 \mathrm{~m}$ south of the SRS boundary and $700 \mathrm{~m}$ north of State Highway 278. The proposed access road is within a $122 \mathrm{~m}$ wide easement that begins at Phelps Road and follows dirt road SRS 219 in an easterly direction for about 350 meters. At this point the project boundary begins to diverge until it reaches the Upper Three Runs Creek 


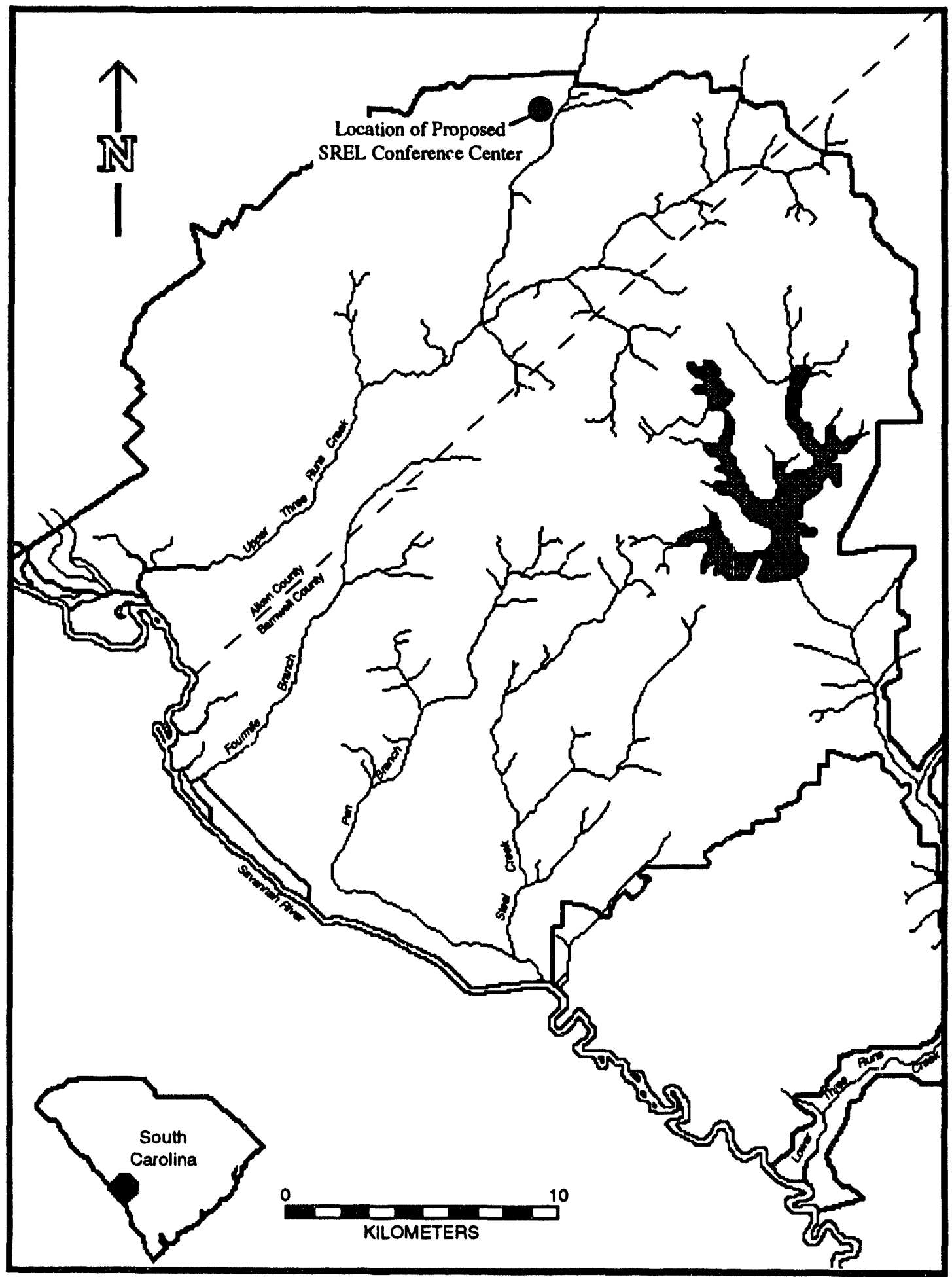

Figure 1. Location of project area within the Savannah River Site, South Carolina 


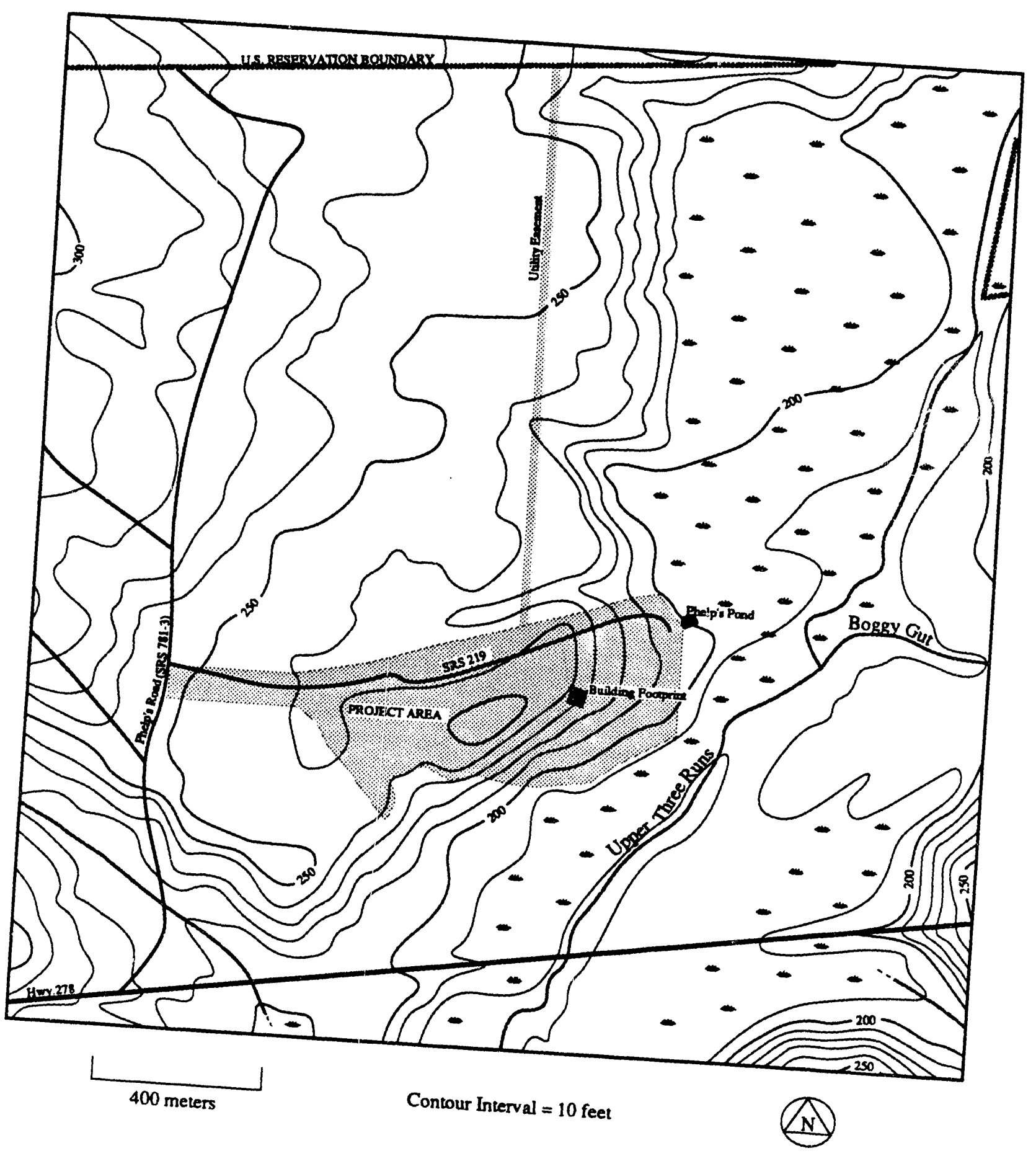

Figure 2. Topographic map of project area and relevant landmarks. 
Archaeological Survey of the Proposed SREL Conference Center

floodplain, which it fronts along a $900 \mathrm{~m}$ wide boundary. A seven meter wide utility easement originates along the north boundary of project area about $400 \mathrm{~m}$ to west of the terrace and continues north some $1,450 \mathrm{~m}$ to the SRS property line.

As part of the sandhills formations of the Aiken Plateau, the project area is situated on an upland ridge formed by the dissection of intermittent streams that drain in an easterly direction into Upper Three Runs Creek. Surface elevations within the project area range from 190-250 ft above mean sea level. Soils in this area are predominantly of the Blanton-Lakeland association, with minor areas in the Troup and Vaucluse series. These soils are well drained to excessively well drained and are associated with slopes of 0-10 percent (Rogers 1990).

Current land-use within the project boundary involves Savannah River Forest Station (SRFS) management of several pine plantations. Located in Timber Compartment 23, the project area primarily includes portions of Timber Stands 4, 6, and 7 (Figure 3). Stand 4 is a 37-year-old slash pine (Pinus caribaea) plantation (Figure 4). Stand 6 contains 8-year-old loblolly pines (Pinus taeda) (Figure 5), and Stand 7 is a 28year-old longleaf pine (Pinus palustris), mixed hardwood tract abutting the floodplain (Figure 6). The major portion of the project area is divided almost equally between Stands 6 and 7. The utility easement crosses Stands 11 and 13, which are in slash and longleaf pine, respectively. The actual Conference Center will be located in Stand 7. After construction is completed, SRFS will remove the project area from commercial timber harvesting, however other forest management activities such as timber stand maintenance would continue as necessary.

In accordance with an existing SR-88 Site Use Application (SU-88-03-F), the SRFS would complete a planned timber thinning operation in Stand 4 along with timber clearing at the Conference Center site prior to construction. Timber thinning involves the removal of young, low quality trees, thereby stimulating the growth of those with high quality. This land-use activity results in minimal impact to archaeological deposits, and therefore no adverse effects to cultural resources are anticipated during this operation.

The majority of the proposed 70-acre project area will remain preserved in its present natural state. In line with the educational facility concept, development and maintenance of nature trails, gardens, and research demonstration areas for upland environmental interpretation are planned. Only a relatively small portion of the project area will be impacted from construction activities (5-10 acres). This would involve improving access to the Conference Center, and land clearing for building construction and a parking lot. Access to the Conference Center would follow the existing road (SRS 219), which would not be paved, but along with the parking lot, graded and covered with crushed rock. The proposed building is a one-story wooden-frame structure of about $4000 \mathrm{ft}^{2}\left(371.6 \mathrm{~m}^{2}\right)$ with a footprint of approximately $95 \times 40 \mathrm{ft}(29 \times 12 \mathrm{~m})$.

The original design for the Conference Center located the building some $100 \mathrm{~m}$ from the Upper Three Runs Creek floodplain. It was apparent early in the fieldwork for the project that construction in this location posed a significant threat to shallow deposits of site 38AK289. In consultation with the SRARP, SREL personnel agreed to relocate the building footprint to the west some $100 \mathrm{~m}$ upslope. This removed the building from areas of 38AK289 that contain significant, shallow archaeological deposits.

The change in building location precipitated changes in the location of the utility easement. The original easement followed the terrace edge of Upper Three Runs Creek. 




Figure 3. Current land-use in vicinity of project area. 


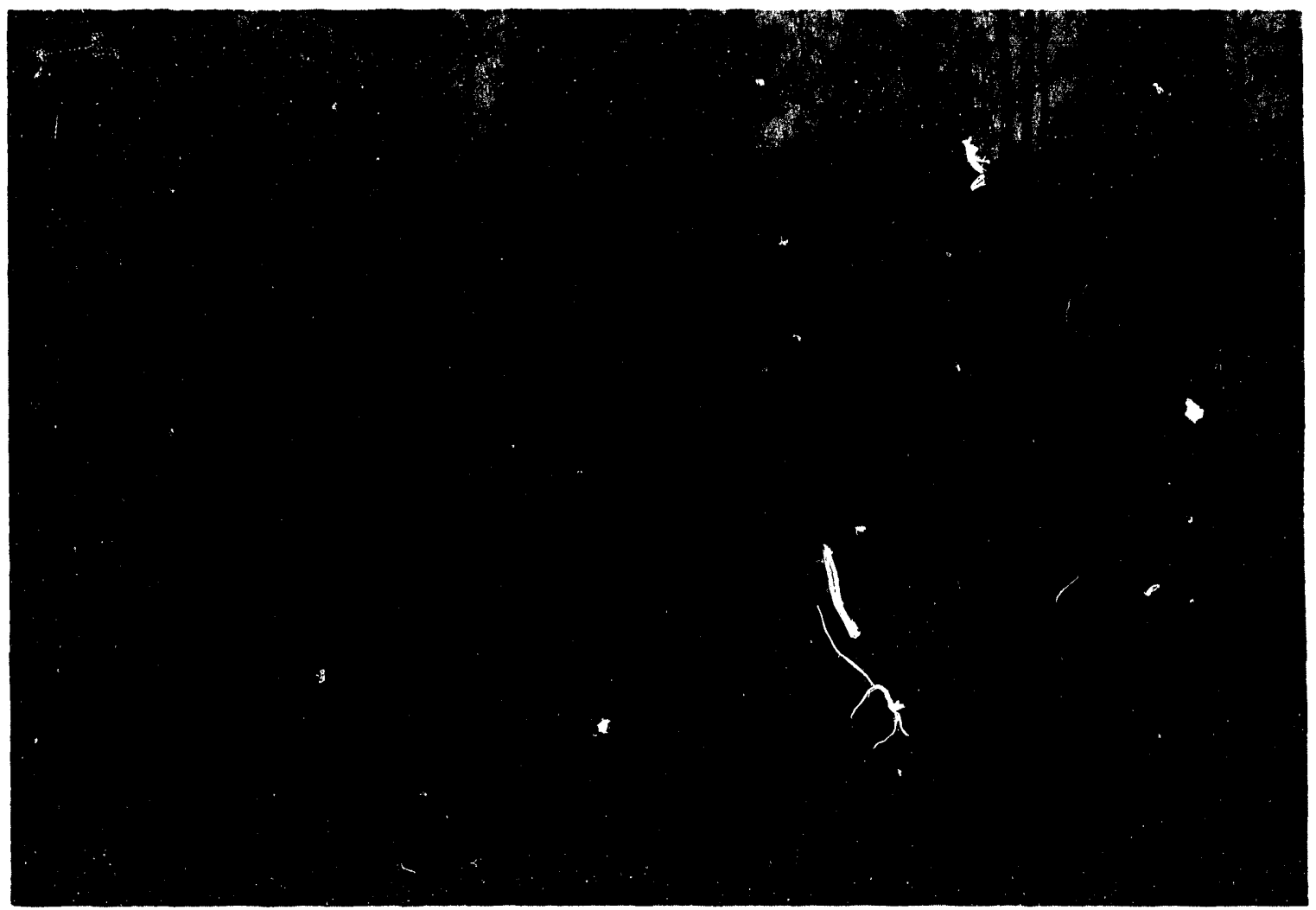

Figure 4. View of mature pine plantation in Stand 4.

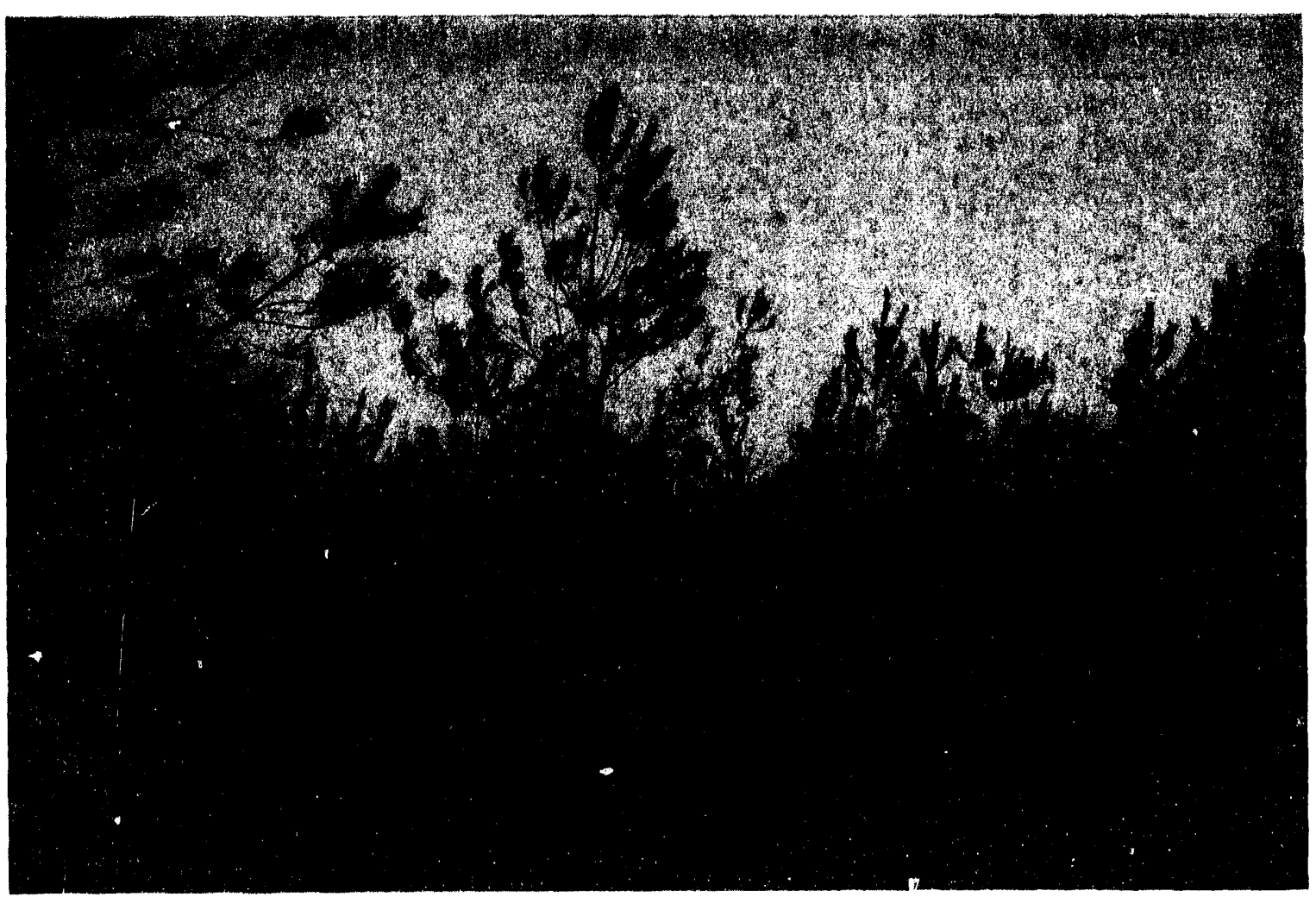

Figure 5. View of immature pine plantation in Stand 6. 


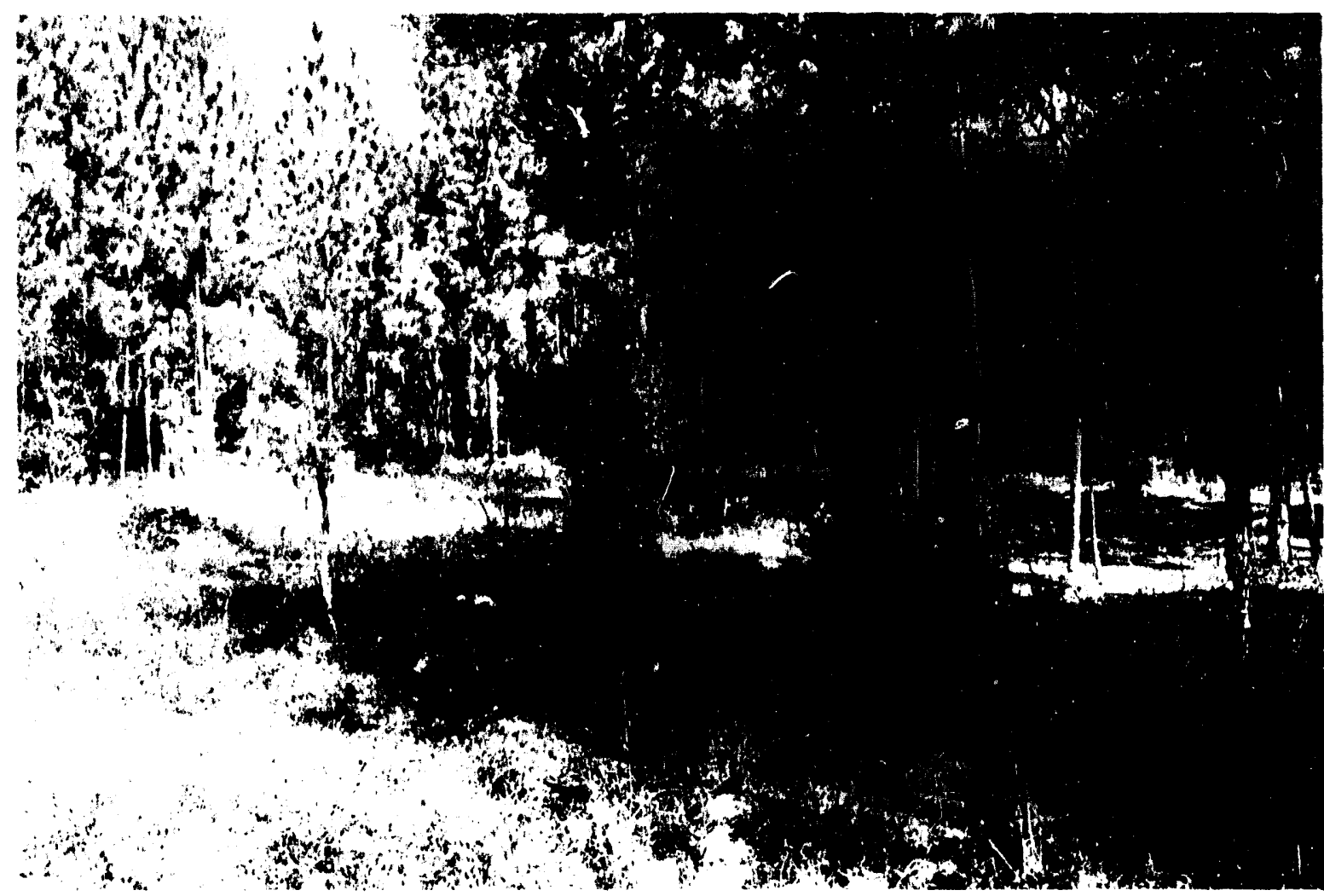

Figure 6. View of mixed pine-hardwood community in Stand 7.

Archaeological investigations along this right-of-way involved five sites, 38AK287, $38 \mathrm{AK} 288,38 \mathrm{AK} 274,38 \mathrm{AK} 282$, and 38AK283. The revised utility right-of way (Figure 2) avoids all but one of these sites (38AK287), but implicates another site, 38AK466.

The location and boundaries of archaeological sites discussed in this report are depicted on the USGS New Ellenton, S.E. topographic quad in Figure 7, as are the boundaries of the project area. The contexts for evaluating the significance of these archaeological resources are discussed in Chapter 2. Methods of survey are provided in Chapter 3, and the results of investigations are fully reported in Chapter 4 . Conclusions and recommendations are provided in Chapter 5.

\section{Synopsis of Results}

Intensive archaeological survey at the proposed location of the Conference Center commenced on August 19, 1992 and continued intermittently through January 15, 1993 for a total of 43 work days. The survey team consisted of two to four archaeologists working individually and in pairs. Field work included 400 shovel tests and the excavation of five $1 \times 1 \mathrm{~m}$, eight $1 \times 2 \mathrm{~m}$, and one $2 \times 2 \mathrm{~m}$ test units. Two previous archaeological sites (38AK287 and 38AK289) were revisited and tested and one new archaeological site (38AK466) was located within the project area. Four previously recorded sites (38AK274, 38AK282, 38AK283, and 38AK288) and two artifact occurrences were investigated during survey of the original utility easement before it was relocated. One previously recorded historic site (38AK284) in the vicinity of the original utility easement could not be relocated due to inadequate documentation in the site file. 


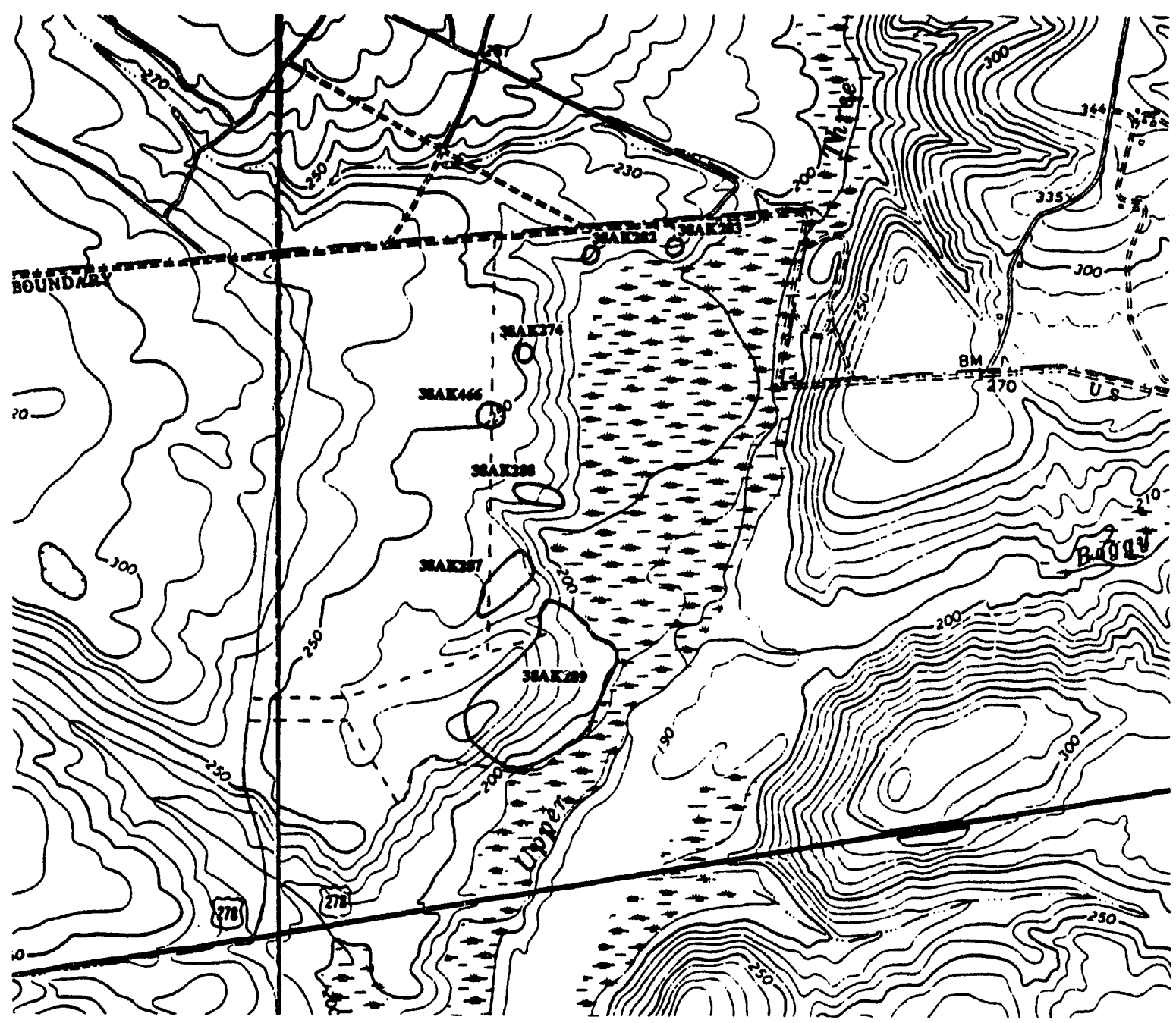

CONTOUR INTERVAL 10 FEET

Figure 7. Location of sites in and around project area on the New Ellenton (1965; photorevised 1971) and Windsor (1965) USGS 7.5 topographic quads.

Sites 38AK287 and 38AK289 contain stratified archaeological deposits that span 10,000 years of human prehistory and history. Research questions dealing with regionalscale economic and social development throughout this time can be addressed through analyses of these resources. In particular, the sites contain Early Archaic and Late Archaic deposits that can inform on the social and economic relationships of groups occupying the Coastal Plain-draining river valleys adjacent to the Savannah River. In addition, some of the earliest historic-era occupations of the interriverine Upper Coastal Plain are represented at 38AK289. Because of the spotty documentary record, archaeological data for this period are critical to an expanded understanding of backcountry history in South Carolina. 


\section{CHAPTER 2 \\ ENVIRONMENTAL, ARCHAEOLOGICAL, AND HISTORIC CONTEXTS}

Comprehensive reviews of the environment and culture-history of the Upper Coastal Plain are provided in the recent syntheses of archaeological investigations on the Savannah River Site (SRS) (Brooks and Crass 1991; Sassaman et al. 1990). This chapter is not intended to duplicate these works, but rather to provide a project-specific context for the design and implementation of the survey strategy and as a foundation for evaluating the results of survey.

\section{Environment and Prehistoric Settlement Patterns}

Situated in the Upper Coastal Plain of South Carolina, the SRS encompasses the watersheds of several streams that flow southwesterly into the Savannah River. The project area lies on the western margin of Upper ?nree Runs Creek, the largest tributary within the SRS.

Ranging in elevation from 24-122 m (80 to 400 feet) above mean sea level (amsl), the physiography of the SRS is comprised of two major components: the Aiken Plateau and the alluvial terraces of the Savannah River (Figure 8). The Aiken Plateau is a dissected sandy plain situated between the Savannah and Congaree Rivers in the Upper Coastal Plain of South Carolina. Its sandy sedimenis dominant the SRS landscape and range in elevation from 76-122 $\mathrm{m}(250$ to $400 \mathrm{ft})$ amsl. The alluvial terraces of the Savannah River occur below the $76 \mathrm{~m}$ elevation level. The project area is situated well within in the Aiken Plateu, some $18 \mathrm{~km}$ from its contact with the Savannah River terraces.

Specific topography of the SRS is the combined result of structural elements, ancient marine processes, and more recent fluvial dissection. The major channels of tributaries follow fault lines and marine features, but their numerous feeder streams in unconsolidated sediments lend a great deal of topographic relief to the upland sandhills. Such formations in the Aiken Plateau are particularly sharp along the margins of Upper Three Runs and Lower Three Runs creeks, the area's two largest tributaries. Exposures of quartz cobbles, orthoquartzite, and low-grade "chert" are found in the steep cut banks of these streams. These resources were exploited prehistorically by groups that occupied nearby ridge nose sites during the Early and Middle Woodland periods (Sassaman 1991, 1992a).

Interfluvial ridges of the Aiken Plateau are characterized by relatively xeric vegetation dominated by pine (Shelford 1963:86-87). More mesic communities with abundant oak are found on terminal ridgenoses and slopes adjacent to active tributary stems (Barry 1980:97-116; Hanson et al. 1981:31). Major tributary streams in the Aiken Plateau, such as Upper Three Runs, have formed broad floodplains which support hydric flora in areas which are regularly flooded, as well as diverse mesic communities along floodplain margins and terraces. Thus, the topographic gradients of the Aiken Plateau created by tributary dissection support vegetative gradients comprised of xeric, mesic and hydric communities (Hanson et al. 1981:28-36; Langley and Marter 1973; Whipple 1978; Whipple et al. 1981). This topographic gradient is especially marked along the upper reaches of Upper Three Runs Creek, which includes the project area.

Like many other locations in the Aiken Plateau, the prehistoric food resource potential of the project area depended on its degree of fluvial dissection. Beginning with spring-fed tributary stems that dissect the sandhills, and moving downslope, resource potential improves with the gradient increase in moisture and soil productivity. Within 


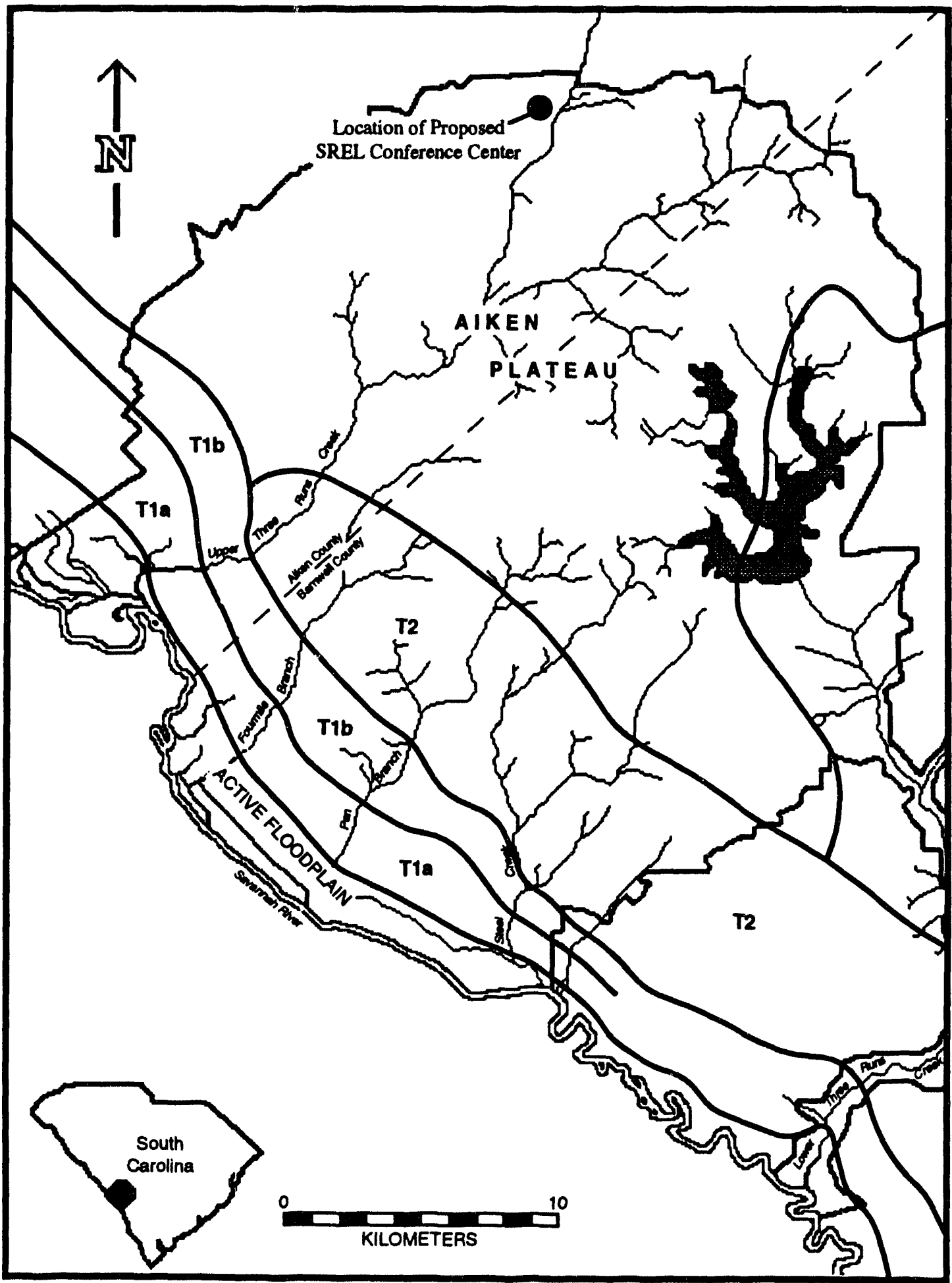

Figure 8. Physiography of the Savannah River Site area. 
this zone of dissection, oak mast is especially dense and productive. This resource, particularly the red oak group, was undoubtedly important to deer and humans alike. Noting this, Hanson proposed that the sandhills was targeted by humans for exploitation during the late fall and early winter-seasons during which deer and acorn were most available (Hanson et al. 1981:42). Because water was the primary limiting factor over much of this zone, however, Hanson predicted that residential sites were positioned on the mesic terraces of tributaries, locations from which upland resource procurement trips were launched.

Archaeological investigations through the late 1980s on the SRS have tended to confirm Hanson's settlement model, as have numerous others surveys elsewinere in the Georgia and South Carolina sandhills province (e.g., Braley 1992; Braley and Price 1991, King and Braley 1992). Not until 1987, when the SRARP had the opportunity to excavate upland ridgenose sites along Upper Three Runs Creek, did it become apparent that resources typically regarded as "lithic and ceramic scatters" contained evidence for seasonal or multi-seasonal habitation by small groups (Sassaman 1987, 1989, 1991, 1992a). Enabling this revelation were large-scale hand-excavated blocks from which piece-plotted artifact data were generated to infer patterns of site use. Garnered from these data were evidence for structures, cooking hearths, refuse disposal areas and lithic workshops. In addition, analyses of lithic assemblages showed that by 3000 B.P., inhabitants of upland sites began to exploit local sources of low-grade raw material and to recycle the scavenged refuse of their transient predecessors (Sassaman and Brooks 1990).

Combined with the results of survey throughout the SRS, excavation results from sites in the Aiken Plateau provide sufficient data to generalize about changing patterns of upland site use. From this work we have found nothing to alter Hanson's model as it pertains to the Early and Middle Archaic Periods (Figure 9). Sites along the terraces of the Savannah River were preferred habitation loci, whereas upland sites in the Aiken Plateau appear to have been visited by hunters or other specialized task groups for only short periods of time.

By 4000 B.P., use of the Aiken Plateau included at least seasonal habitation at bluff margins overlooking tributaries and at the confluences of major stream stems (Figure 10). It is likely that riverine sites like Stallings Island and Lake Spring were occupied in the spring and summer by large groups. Furthermore, these groups apparently dispersed into the uplands for the fall and winter, provisioning their stays with large chert bifacial cores, soapstone cooking stones, and eventually pottery. Direct evidence for Late Archaic structures in the Aiken Plateau has not been found. However, recent excavations by Jerald Ledbetter (1991) at the headwaters of Brier Creek in Georgia have uncovered an isolated fourth millennium pithouse with an internal hearth. Presumably the cold weather structure for a small household, the pithouse may reflect the sorts of dispersed occupations expected for tributaries of the Savannah River. In the absence of organic preservation, the archaeological signature for pithouses would look much different than the evidence found for warm weather structures. Thus, it is possible that pithouses have been routinely overlooked in the Aiken Plateau. Parenthetically, recent excavations at 38AK 157 in the Aiken Plateau have led to a recognition of artifact patterning arguably resulting from the use of Late Archaic and Early Woodland habitation structures (Sassaman 1992a).

Year-round occupation of the Aiken Plateau commenced sometime after 3000 B.P. Sites of this period are numerous and are distributed widely along bluff margins and at springheads (Figure 11). Proportionately fewer sites are located along the terraces of the Savannah River; those that have been investigated have not produced evidence for 


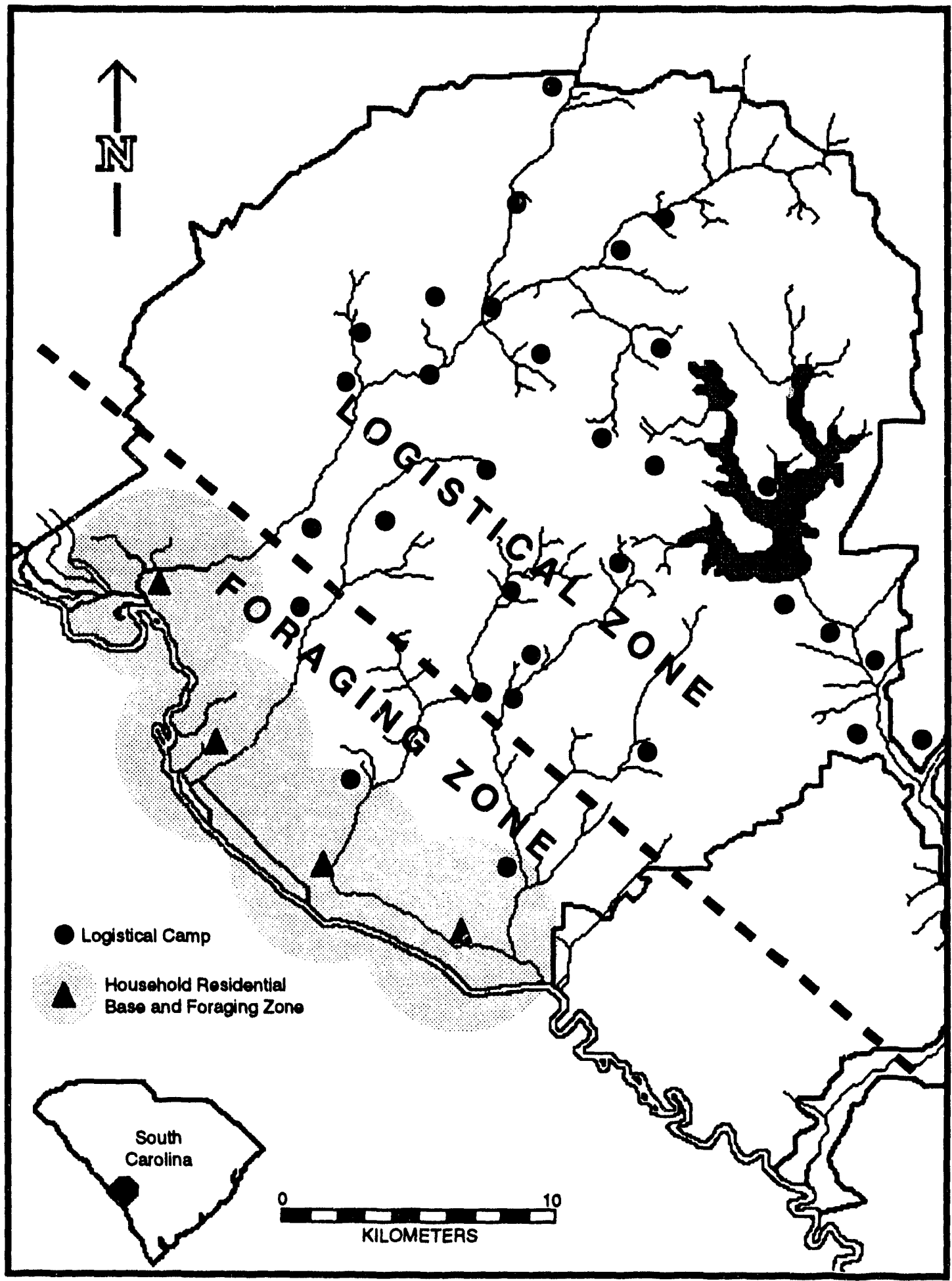

Figure 9. Model of early to mid-Holocene prehistoric settlement in the Savannah River Site area. 


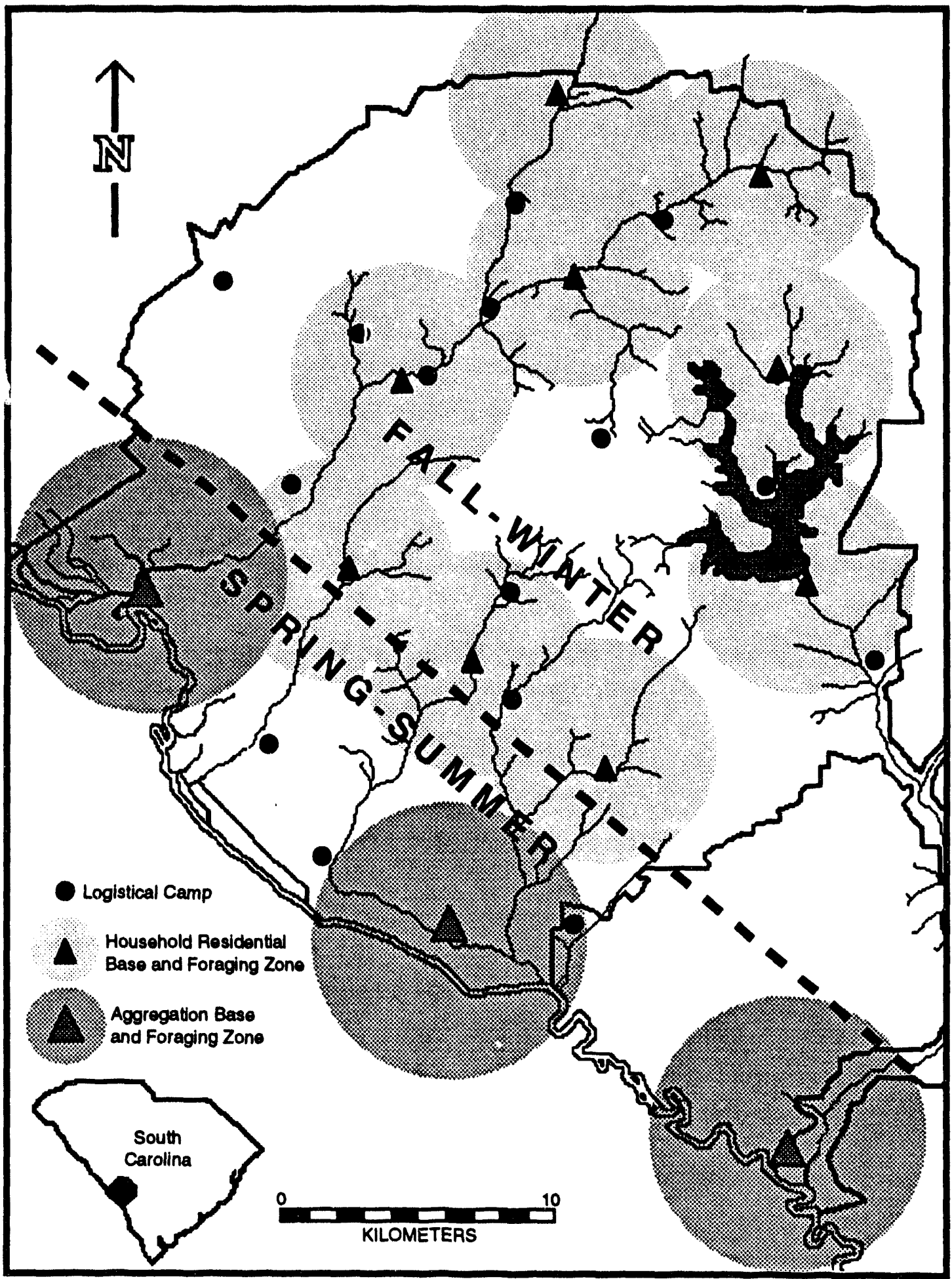

Figure 10. Model of Late Archaic prehistoric settlement in the Savannah River Site area. 


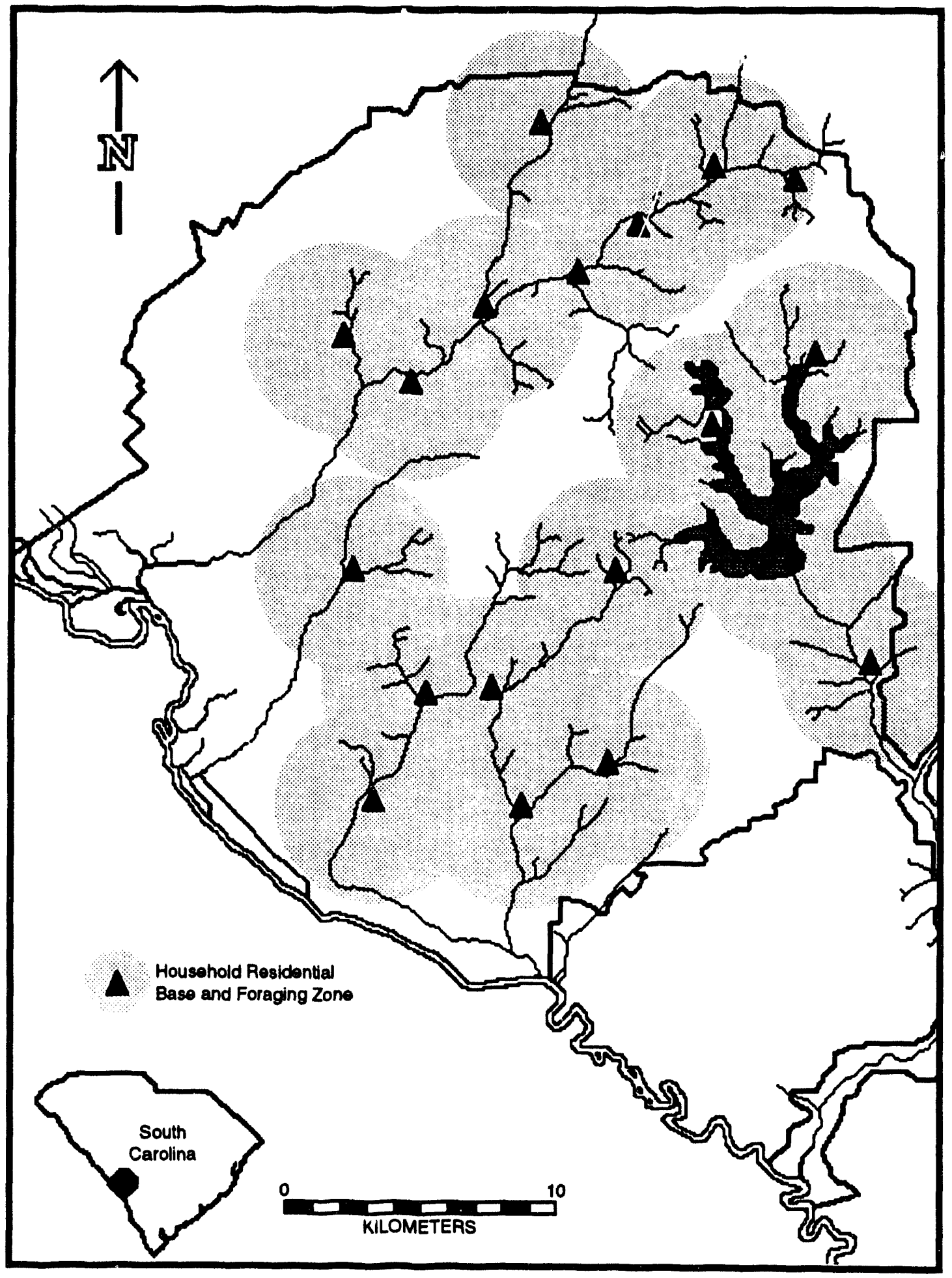

Figure 11. Model of Early Woodland prehistoric settlement in the Savannah River Site area. 
utilization that exceeds Aiken Plateau habitations in scale or duration. By all indications, Early Woodland occupation of the Aiken Plateau was perennial. This is not to say that settlement was sedentary for we have, as yet, found evidence for only warm weather occupations (Sassaman 1991, 1992a). Instead, we suspect that groups moved to strategic locations within the Aiken Plateau, such as the confluences of major tributary stems, during the fall and winter to maximize access to the mesic vegetation of ridge slopes and stream terraces. The relative abundance of oak mast in these zones undoubtedly attracted deer into the area, and presumably species higher up on the food chain, especially humans.

Explanations for intensified upland site use remain a subject of considerable discussion. From his investigations of four sites on the second terrace of the Savannah River along Steel Creek, Brooks views fluvial responses to mid-Holocene sea level rin as a stimulus to increased upland resource potential (Brooks and Hanson 1987). He indicates that the onset of modern floodplain development in the Upper Coastal Plain of the Savannah River valley at ca. 4000 B.P. (Stevenson 1982) established the local fluvial base level that led to subsequent hydrologic changes in upland tributaries. This resulted in increased biomass of aquatic plant and animal resources as tributaries adjusted to a low-energy flow and mature floodplain regime. Importantly, these newly productive resources constituted spring and summer foods that were heretofore limited to mesic terrace zones below the Aiken Plateau. Given this new potential, along with attendant improvement in deer habitat, Brooks posits that upland utilization changed from fall resource procurement (i.e., deer and nuts) prior to ca. 4000 B.P., to seasonal habitation along upland tributaries during the Late Archaic period, leading eventually to multiseasonal habitation within upland zones by the Early Woodland period. Tests of these postulates with excavation data from four sites in the Steel Creek watershed were generally supportive (Brooks and Hanson 1987).

From a regional perspective, the results of recent excavations in the Upper Three Runs drainage (Sassaman 1989, 1992a) bring to the fore a complementary model of intensified upland site use based on sociopolitical process. The regional picture reflects dramatic changes in the organization of populations that obviously had some bearing on the scale and duration of upland occupations. During the Late Archaic period (5000-3000 B.P.) subsistence production was at times organized at a multi-household or communal level at large riverine sites like Stallings Island (Claflin 1931). Interregional exchange, elaborate ceremonialism, and other spheres of social interaction were both precedents for and products of intensified production, putting demands on the labor of individuals for nonsubsistence funds. Utilization of upland sites during this time appears to have been seasonal, probably late fall and winter, and facilitated by group dispersion. Both the direct obligations of seasonal aggregation and the indirect costs of nonsubsistence production to support these formations put a check on the scale and duration of upland site use. Households were unable to sustain long-term occupations in the uplands not because of an inadequate food or water supply, for indeed paleoenvironmental indications show that by 4000 B.P., resource productivity in the uplands was on the rise. Rather, the limits to upland occupation were dictated by the high costs of social reproduction, that is, by the time and energy it took to participate in what appear to have been relatively complex hunter-gatherer societies.

But the centripetal processes that held Late Archaic society together engendered counteracting centrifugal forces. Throughout this period upland occupations provided the opportunity for households to disengage from obligations that placed excessive demands on individual labor. Apparently, households began to exercise this option in increasing numbers after 3500 B.P., a time when the long distance reverberations of interregional 
exchange (e.g., Poverty Point) may have placed additional demands on production. We suspect that the dissolution of the large Late Archaic societies was catalyzed by the fissioning of households into the uplands. Ironically, the seasonal utilization of upland sites during the Late Archaic period predisposed the environment for long-term use by Early Woodland households, so we might say that Late Archaic sociopolitical organization sowed the seeds of its own transformation. More to the point, Early Woodland populations were able to occupy the upland sandhills year-round simply because they assumed social formations that placed little demand on production beyond the subsistence needs of households. For these small-scale, loosely integrated groups, sandhills sites in the Aiken Plateau provided all of the resources for their limited needs.

The settlement models described thus far, whether emphasizing environmental or sociopolitical processes of change, have one thing in common: they are river-centric. The models take as a given that upland tributary occupations in prehisiory can be understood with reference to the conditions of the major rivers into which the tributaries drain. To be fair, this tacit assumption is somewhat justified by ethnographic studies of hunter-gatherers in temperate forests which show that group ranges or territories conform to watershed boundaries (e.g. Kroeber 1925; Watanabe 1968). A recent model of early Holocene settlement in the South Atlantic Slope operates under this assumption as well. According to Anderson and Hanson (1988), Early Archaic bands in the region occupied annual ranges that extended the entire longti of Atlantic draining river valleys. Use of upland tributaries in the upper Coastal Plain, as described above, involved task-specific forays launched from base camps along rivers. Movement between valleys is anticipated by Anderson and Hanson as a means of group integration, but this is characterized as chiefly a seasonal phenomenon at sites along the Fall Zone. It follows from their argument that site functions and locations along upland tributaries are components of the settlement system centered on the river into which the tributaries flow.

Some criticism of the Anderson and Hanson (1988) model has been raised by Daniel (1992) who posits greater interdrainage movement of people during the Early Archaic period. Evidence for such movement, according to Daniel, is found in the distributions of raw materials used to make hafted bifaces. Indeed, some interdrainage movement of raw materials is apparent in the Coastal Plain of South Carolina, but it pales in comparison to the displacement of materials along major river courses such as the Savannah and the Pee Dee rivers (Sassaman 1992b). These data lend credibility to the Anderson and Hanson model, though we point out that the mechanisms for acrossdrainage movement of raw material in the Coastal Plain, however insignificant they may have been, are not anticipated by the model. Sassaman (1992b) suggests that hunting forays into the interriverine areas of the Upper Coastal Plain, as specified by Anderson and Hanson, offered the opportunity for groups from adjacent drainages to interact on a seasonal basis. Some production of Coastal Plain chert Kirk Corner-Notched bifaces at the G. S. Lewis-East site (38AK228E) near the Savannah River was designed to provision hunting parties for long-distance forays into the uplands, and may have included nonsubsistence demands related to social interaction (e.g., exchange) (Sassaman 1992c).

Independent of the interaction hypothesis, we may want to consider that remote upland sites in the Savannah River drainage were visited regularly by groups that spent most of their time in the adjacent river valley. Taking into consideration that the project area, for instance, is in closer proximity to the South Fork Edisto River than it is to the Savannah River (Figure 12), this question is certainly worthy of investigation. But to do so requires abandonment of the river-centric assumptions of existing models. Instead, we should consider that geographical proximity may be a more important determinant of 


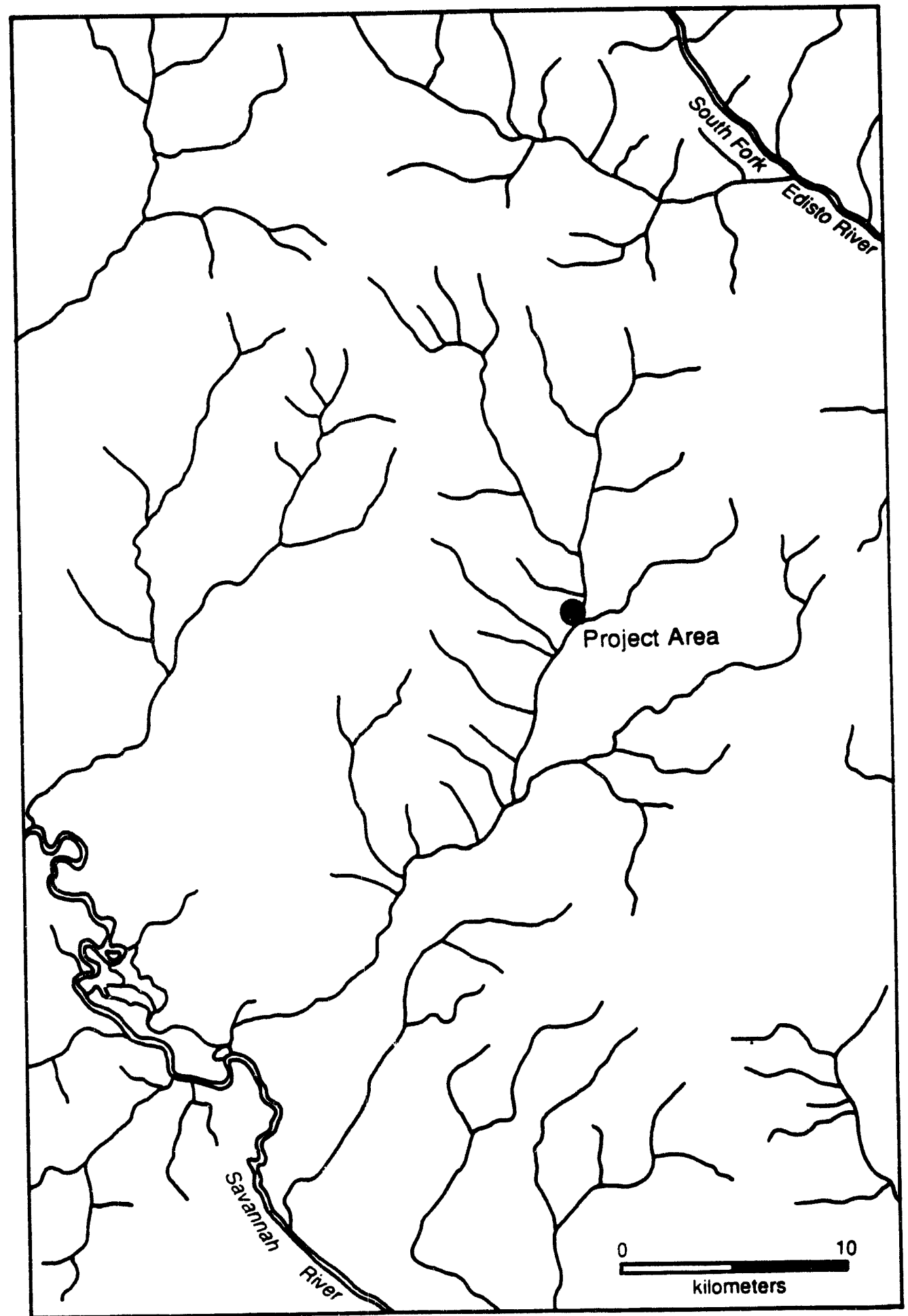

Figure 12. Geographic relation of project area to the Savannah and South Fork Edisto rivers and associated tributaries. 
social affiliation and interaction than is the physiography of fluvial systems. Likewise, the role of tributary divides as pathways of communication and mobility. Because of its diminutive size, the South Fork Edisto basin has a divide that closely parallels the river and leads directly into smaller rivers, such as the Salkehatchie, that originate in the Middle Coastal Plain.

The significance of this line of thinking lies not in alternative ways of conceptualizing geography, but rather, in alternative processes for sociocultural organization and change. For the early Holocene, the role of Coastal Plain-originating rivers in band formation and interaction has not been adequately discussed. For instance, in the Anderson and Hanson (1988) model of Early Archaic organization, the SavannahEdisto divide marks the boundary between the "Savannah" and "Saluda/Broad" bands. However, the Edisto basin lies equidistant between the two Piedmont-draining rivers for which these bands are named, so the assignment of the Edisto basin to one or the other appears to be completely arbitrary. Allowing that distinct Early Archaic bands did occupy the major rivers valleys, it seems perfectly reasonable to expect equal use of Edisto basin sites by both the "Savannah" and the "Saluda/Broad" bands. It follows that interaction at tributary divides, as suggested above, would have greatly facilitated the flow of information and materials among constituent bands. This would account for the interdrainage movement of lithic raw materials in the Coastal Plain, and, more importantly, provide an alternative for large-scale aggregation that may have significantly weakened the bonds of cultural affiliation and regional alliance anticipated in the Anderson and Hanson model. This alternative may help to explain why the Santee River Valley assumes something of a cultural boundary during the Early Archaic period (Sassaman 1992b).

In another example, the history of occupations in small Coastal Plain river basins in Late Archaic lifeways may elucidate some of the sociopolitical processes of change outlined above for the Late Archaic period. One might argue, for instance, that groups occupying small Coastal Plain river valleys such as the Edisto and Salkahatchie were politically disconnected from the goings-on at riverine sites along the Savannah River. At the same time, these groups probably had some social connection to Savannah groups during seasons of upland dispersal. If so, the social opportunities available at divide locations may have helped to erode the centripetal processes that held large Savannah River valley communities together. One result would be shifts in social alliance and interaction that would be manifested archaeologically in the rise and fall of cultural "phases." In this regard it should be noted that the final local phase of the Late Archaic period (Phase III, ca. 3400-3000; Sassaman 1993) marks the demise of sociopolitical integration in the middle Savannah River valley and the appearance of a small, loosely integrated population occupying the Salkahatchie and Coosawhatchie river valleys, the last makers and users of fiber-tempered pottery and soapstone cooking slabs.

One can address these sorts of lofty scenarios with archaeological data from small, upland sites in the Aiken Plateau. Data on the raw material variability of Early Archaic assemblages and on the design and use of Late Archaic fiber-tempered pottery and soapstone are relevant to the two questions outlined above. Similar questions about other time periods in prehistory can likewise be addressed. Granted, upland assemblages such as those anticipated in the project area are not usually rich or very large, but when we put these smaller assemblages into a regional context and think about the sorts of regional processes we have discussed here, the size and richness of these assemblages have little bearing on their research significance. Because of our tendency to dwell on the large, rich sites along major rivers, and to think about sociopolitical, even environmental process in a river-centric way, small upland sites have been routinely underestimated or 
altogether misunderstood. The prehistoric archaeological resources of the current project area may provide an opportunity to continue remedying these biases.

\section{Historic Period Settlement}

The last few centuries of human occupation in the SRS area ran a course that in some respects paralleled prehistoric settlement. Early in the historic occupation of the SRS area, during the Colonial Period of the mid- to late eighteenth centuries, settlements were concentrated along the terraces overlooking the Savannah River and its major tributaries (Brooks and Crass 1991). These trends continued through the Antebellum Period of the nineteenth century, with gradual increases in the number of settlements and occupation of upland locations. Settlement in the SRS area burgeoned in the Postbellum/Modern Period, when there was a greater tendency for sites to be located in less desirable interriverine portions of the Aiken Plateau.

The settlement changes documented by Brooks and Crass (1991) are explained as a response to population increase, changing economic organization, and technological innovation. The riverine orientation of early settlement was strongly influenced by transportation options (i.e., the watercourses) and the demand for productive agricultural land. Because farming and other agricultural activities prior to the mid-nineteenth century remained small in scale, residences were located next to fields, hence the direct correlation between soils of riverine and tributary terraces and early historic settlements.

The increased use of upland sandhills locations after the Civil War coincided with agricultural intensification, including monocropping, and development of the tenant land tenure system. Prime farmland along the Savannah River and its tributaries continued to be used, but agricultural intensification led to increased use of less-productive land in the uplands. These locations were generally occupied by renters and sharecroppers who had little option for more productive land, nor the need or power to command hubs of transportation and information. In addition, the increased use of wells abated the need to locate residences near sources of running water. The result is that by the early twentieth century, many interriverine areas of the SRS previously ignored or underutilized were densely occupied by tenant farmers. Aerial photographs and maps dating to the $1940 \mathrm{~s}$ and early 1950s document over 6000 late historic structures within the present-day boundaries of the SRS; the vast majority of these are located in interfluvial areas of the upland sandhills (Brooks and Crass 1991:79).

Thus, an increase in the use of upland sites during the historic period parallels the patterns observed during late prehistory. These patterns diverge, however, when we consider the specific locations of late historic period residences within the uplands. While prehistoric sites remained tied to locations of running water, late historic residences are often located $500 \mathrm{~m}$ or more from streams (Brooks and Crass 1991:64). In essence, these late historic sites are the only potentially significant archaeological resources located in the interriverine portions of the upland sandhills. As noted earlier, these sites are typically visible on aerial photographs of the SRS, and records of residences occupied when the Atomic Energy Commission acquired the land in the early 1950s are maintained by the Department of Energy-Savannah River Field Office.

What remains elusive about the historic occupations of the Aiken Plateau is information about the late eighteenth and early nineteenth century pioneers that established permanent settlements in an otherwise underdeveloped area. As archival data show, one of the earliest permanent backsettler sites in the Aiken Plateau was located within the project area for the SREL Conference Center. 
Archaeological Survey of the Proposed SREL Conference Center

\section{The Archival Record of Historic Period Occupation in the Study Area}

When the Atomic Energy Commission (AEC) purchased land for the SRS during the years 1950-52, a tract number was assigned to each piece of acquired property (Brooks and Crass 1991:87). According to the United States Atomic Energy Commission Acquisition Land Tract Register, the 70-acre project area makes up a portion of a 1,177 acre parcel recorded as Tract M-1228 (United States Atomic Energy Commission Acquisition Land Tract Register [USAECALTR] M-1228). A chain of title search for the area included in M-1228 produced a partial sequence of landowners dating back to the late eighteenth century (Richardson 1992).

On the 5th of August, 1793, Elkanah Green was granted a 476 acre tract along the west bank of Upper Three Runs Creek by the State of South Carolina. Little is known of Green during his stay in the project area. He was given 500 acres on Hollow Creek in Barnwell District on 17 September 1785 by a Acquilla Low. Interestingly, this gift is recorded, along with a similar one for 300 acres to Richard Treadaway who lived just south of the project area, in the Audited Account Books for the American Revolution (South Carolina Revolutionary War Audited Account [SCRWAA] Elkanah Green Account 4691, 17 September 1785). Green and Treadaway may have served together in the same unit during the war, although Low's role in this episode remains a mystery.

In 1787, Green apparently gave his property to an Absalom Green (SCRWAA 4691, 30 July 1787). Elkanah Green's household in 1790 included 3 males over 16 years of age, 5 males under 16 years of age, 6 females, and one slave (Orangeburg District Southern Part Population Census [ODSPPC] 1790). In 1793 he acquired by state grant 476 acres along on the west bank of Upper Three Runs (although he or someone else may have lived on the property prior to this date; see below). Green's newly acquired holdings along Upper Three Runs comprised the western portion of M-1228 where the project area is located (Richardson 1992:4-5).

In 1800 Green was taxed for 858 acres, but apparently held no slaves (Winton County Tax List [WCTL] 1800). At this time his household included four males under 10 years of age, one male between 10 and 16 years old, one male between 26 and 45 years of age, one female aged 10 to 16 years, and one female aged between 26 to 45 years [Barnwell District Population Census (BDPC) 1800]. By 1810 Green had apparently left the area, since he is absent from the census tracts. An 1825 map of the Barnwell District produced from a survey by Thomas Anderson in 1818 does not show any habitation in the area of Green's property along Upper Three Runs (Mills 1979 [Originally 1825]). However, historic period artifacts from the project area (see Chapter 4) strongly indicate that there was in fact a habitation site on the tract during this time frame. Other historic sites on the SRS from this time period are also notable by their absence on Mill's Atlas, implying that his surveyors did not capture everyone living in the area.

At this point, there is a temporal and chronological gap in Richardson's (1992) report until the chain of title is picked up once again in the late nineteenth century. After almost a century of historic settlement in the area, property boundaries of the original 476 acre tract had most certainly changed, although to what extent is not known. By 1888 , the tract totalled 500 acres and was in the possession of H. D. Evans of Georgia and J. D. Steadman, a co-owner. However, during that year, J. Henry Busch (apparently the previous landowner) sued Evans and Steadman in the Aiken County Court of Common Pleas due to an unsatisfied mortgage of $\$ 2,648$ on the property. The land was ordered to be put up for public auction where it sold for $\$ 575$ to Busch, the highest bidder. In 1898 , 
the tract was purchased by Hampton Sapp, who later that year found his estate being sued by Busch in the Court of Common Pleas for the $\$ 2,070.41$ owed on the property. Once again the parcel, which was assessed as farming land, was put up for auction in a Sheriff's sale and awarded, somewhat not surprisingly, to J. Henry Busch as the highest bidder of \$500 (Richardson 1992:3-4).

After these legal events, the property apparently remained in the Busch family until March 23, 1916, when W. W. Holley, Jr. bought the tract from E. H. and Ellie C. Busch (possibly J. Henry Busch's son and daughter-in-law). Along with the Busch property, Holley inherited or eventually purchased three other distinct parcels in the vicinity. There are no plats recorded for these four tracts as Aiken County, formed in 1872, did not require that plats be filed with deeds. Altogether, Holley's holdings total 1,011 acres, which he sold to Claudia Lee Phelps, II on August 14, 1928 (Richardson 1992:1-3).

Throughout the first half of the twentieth century, Claudia Phelps methodically accumulated both small and large tracts of land so that by mid-century she owned 4,191.5 acres in Aiken County. Although no plat delineating the lower portion of Phelps' estate appears in the records, only two deeds describe eastern boundaries along Upper Three Runs and, of these, it seems that the majority of AEC Tract M-1228 was confined within the 1,011 acres acquired from Holley. In a deed dated November 1, 1944, Phelps sold 3,916.05 acres of her property to the International Paper Company, which included the land bordering the west bank of Upper Three Runs on which the project area is located. In July of 1952, the Atomic Energy Commission purchased a portion of this original land plat from International Paper. Listed as AEC Tract M-1228, it consisted of 1,177 acres that began at a point $1,150 \mathrm{ft}$ southwest of the intersection of South Carolina Highway Number 781 (now State Hwy 278) and Upper Three Runs Creek. The western boundary of this tract fronted Upper Three Runs Creek.

Land-use under International Paper Company management was characterized as timber land with a small portion (55 acres) under cultivation. The upland was dominated by scrub oak with recently planted pine seedlings of about one and one-half years growth. The 1,177-acre land value was appraised at $\$ 22,550$.

Included with the land acquisition was a two-acre pond contained by an earthen dam and an associated structure listed as a "Club House". The construction date and purpose of the pond are unknown although there are two spillways located at each end of the dam, one made of bricks and the other of concrete, that may have functioned toward some economic purpose such as milling. All existing structures on property acquired by the AEC were inventoried under a numerical system, photographed, and assessed according to current condition of preservation. In accordance with this procedure, the "Club House" was given the acquisition number 6276, and described as being 12 by $28 \mathrm{ft}$ in size with a frame construction, brick foundation, and metal roof. The records also stipulate that the windows and bathroom fixtures were removed, although it is not clear whether these structural components were removed during or prior to AEC acquisition. An appraisal value for the structure was estimated at $\$ 550$, with a salvage value of $\$ 100$. Although the records do not describe the function of the "Club House," it is assumed that the structure was built during Claudia Phelps' land tenure and served as a lodge for sporthunting members of the Northern contingent residing in Aiken during the winter months.

\section{Conclusion}

Situated deep within the Aiken Plateau, the project area provides an opportunity to examine the archaeological resources of sites geographically distant from the Savannah 
River. Our current understanding of Savannah River Valley prehistory is river-centric, and this has tended to bias our interpretation of remote, upland occupations throughout prehistory. We have proposed some alternative thoughts on prehistoric upland land-use that places such occupations at the center of processes of social interaction and change.

A similar case can be made for extant interpretations of historic period occupations of the Aiken Plateau. Archival records for the project area show that development of upland tracts along Upper Three Runs Creek occurred relatively early, presumably because of the favorable agricultural and/or pastoral conditions, and perhaps access to early markets. But little detail about early historic occupations is known, and the role these assumed in the regional landscape cannot be adequately addressed by archival data alone. Thus, archaeological resources within the project area, particularly those associated with the late eighteenth century settlement of Elkanah Green, have the potential to address issues of regional historical significance. 


\section{CHAPTER 3 \\ SURVEY METHODS}

Previous Survey and Survey Design

Prior to initiating the field survey, a review was conducted of the SRARP site files to determine whether any archaeological resources had been reported in the proposed project area or along either of the rights-of-way. Only one site, 38AK289, was located within the project footprint, and three existing sites, 38AK284, 38AK287, and 38AK288, bordered the proposed (and subsequently relocated) utility easement running north along the terrace of Upper Three Runs Creek. In addition, three other sites (38AK274, 38AK282, 38AK283) were known to exist within the project area vicinity.

Early aerial photographs taken in 1943 and 1951 along with a 1921 U. S. Army, Corps of Engineers topographic map (reprinted in 1944) were examined to identify late historic period sites (standing structures) within the project area. One structure was observed on these cartographic sources. The site was subsequently located during subsurface transect testing of the utility easement and documented as 38AK466. Although the standing remains of an early twentieth century structure were recorded at 38AK289, these were obscured on the aerial photographs because of heavy vegetational growth.

As part of the SRS-wide survey (Sassaman et al. 1990:69-76), a portion of the project area and surrounding vicinity was previously surveyed. Designed as a stratified, random sample, the survey entailed 40-percent coverage of the entire SRS for the purposes of developing a long-term management plan. To facilitate representative coverage in all microenvironments, the SRS was stratified by watershed and Patrol Index Units (PIU) quadrants. Each $2000 \times 2000 \mathrm{ft}$ PIU quadrant was coded for landform and stream rank to derive sampling strata, and from these a 40-percent sample was selected for survey.

The PIU quadrants in and around the proposed Conference Center are depicted in Figure 13. Four PIU quadrants were randomly selected in this area for investigation during the 1982 survey of Upper Three Runs Creek (D-23 NW, D-23 SW, E-23 NW and E-23 SW). Two new sites were located, one (38AK288) in unit D-23 NW and one (38AK289) in unit D-22 SW. Site 38AK289 is situated within the current project area. Concurrent with the random survey, portions of adjacent PIU quadrants also underwent survey. Five additional new sites (38AK274, 38AK282, 38AK283, 38AK284, 38AK287) were recorded. Of these, only $38 \mathrm{AK} 287$ is located within the current project area.

In general, the level of documentation for the existing sites in and around the project area is inadequate to draw conclusions about site size, content, and integrity. The exception is previous testing at 38AK288, which is summarized in Chapter 4 . Two Edgefield scrapers recovered from a test unit provide evidence for Early Archaic site use, while a relatively large sample of plain fiber-tempered pottery serves testimony to relatively intensive Late Archaic period occupations. These results are not unexpected given the proximity of 38AK288 to Upper Three Runs Creek. In fact, much of the project area has potential to contain multicomponent prehistoric sites. Expressed in terms of Archaeological Sensitivity (SRARP 1989), the project area is divided between Zones 1 and 2 (Figure 14). Across the SRS, Sensitivity Zone 1 consists of all lands within $400 \mathrm{~m}$ of streams rank 3 or greater; Zone 2 is all land $401-800 \mathrm{~m}$ from streams rank 3 or greater and all lands within $400 \mathrm{~m}$ of streams less than rank 3; Zone 3 is all other lands with the exception of modern swamps and floodplains. The zones were determined by a locational analysis of over $\mathbf{4 5 0}$ prehistoric sites for which adequate documentation about content was available (Sassaman et al. 1990). 


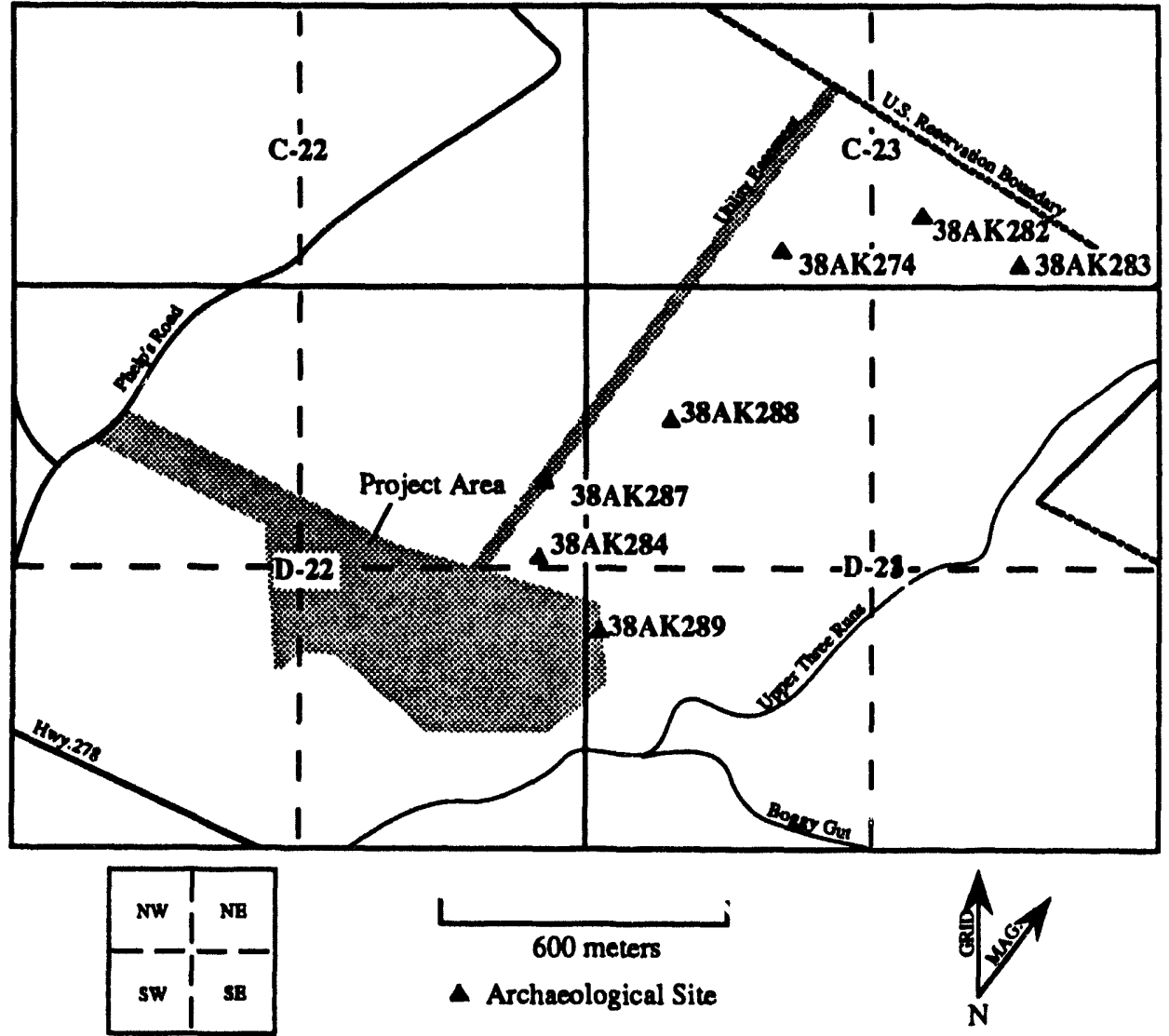

Figure 13. Survey strata (PIU quadrants) of the project area and vicinity.

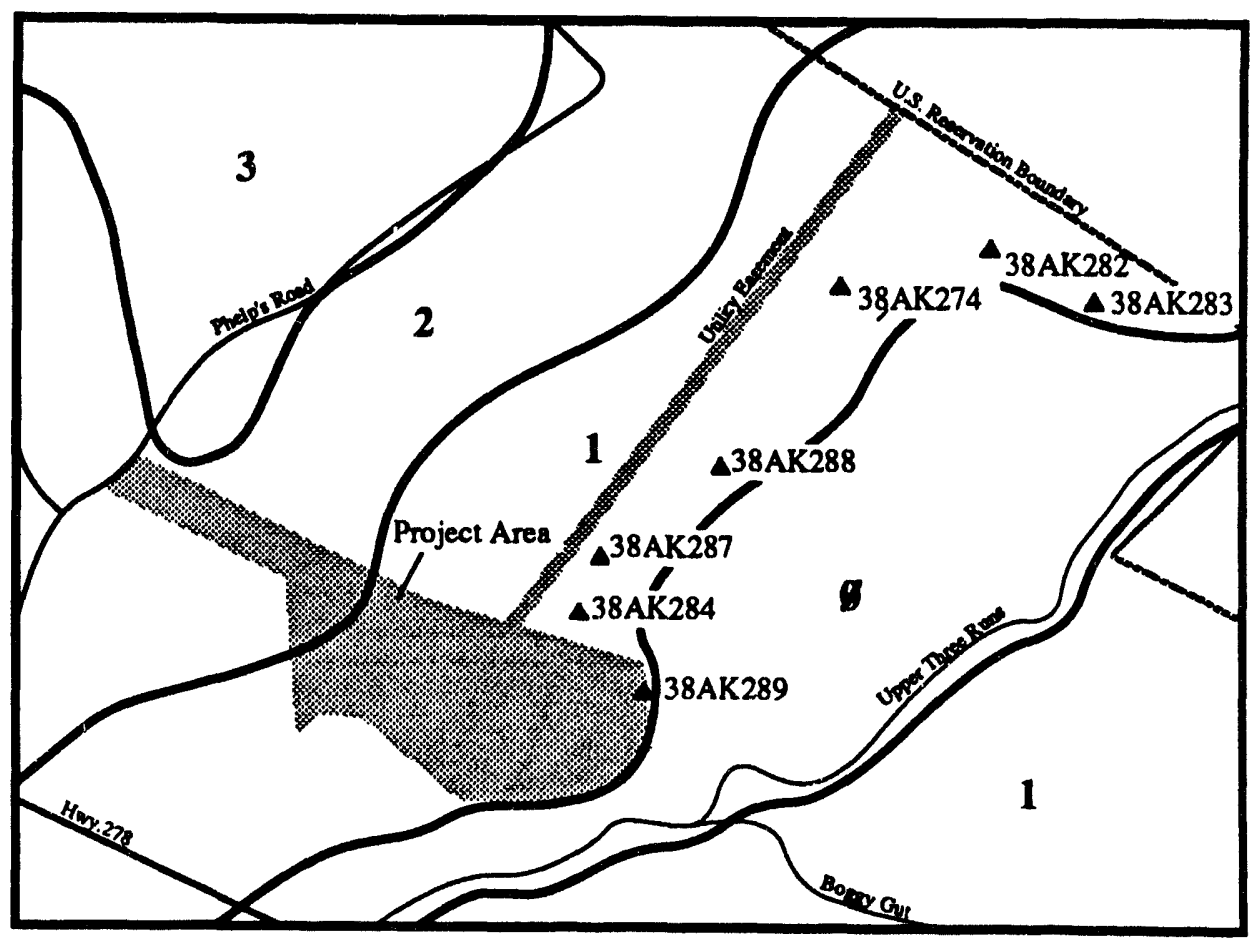

Figure 14. Archaeological Sensitivity Zones of the projeci area and vicinity. 
Site 38AK288 exemplifies the type of sites expected in Zone 1, but like so many other sites recorded in the early years of the SRS survey, its boundaries were poorly documented. Thus, a primary goal for the present study was to relocate all sites in and around the project area to establish boundaries through subsurface testing, and, for those within the project area, to recover sufficient information for assessing archaeological significance.

Although the project area had already witnessed a high level of archaeological survey, our field efforts were designed to apply thorough subsurface testing to not only delineate boundaries and sample content, but to locate new archaeological resources. Both the high level of archaeological sensitivity of the project area and the potential for early historic components not depicted on recent aerial photographs or maps justified the intensive approach taken here. Understandably, our most intensive efforts focused on the immediate footprints of the Conference Center and the utility easements. But as indicated earlier, our efforts were to some extent altered in consultation with SREL personnel. The original design of the Conference Center was changed as archaeological results began to materialize, and, accordingly, the survey design changed to meet these new demands.

\section{Field Methods}

Based on the intensity of previous survey, few, if any new sites were expected in the project area. As noted above, a substantial portion of the survey effort was spent locating and testing previously recorded sites, which in some cases entailed shovel testing in transects to delineate boundaries and to recover samples of subsurface remains. Several controlled test unit excavations were also made to sample subsurface remains in various portions of sites. Based on previous research in the area (Sassaman et al. 1990; Sassaman 1992a), prehistoric sites were expected to be moderately sized, with buried deposits possibly extending to a meter below surface. Most of the prehistoric sites would reflect relatively short-term occupations by small groups due to the remoteness of the area from major river drainages. Archaic and Woodland period lithic scatters were expected to be common, as were assemblages of check-stamped (largely Middle Woodland) and cordmarked (largely Late Woodland) pottery. Clusters containing such artifacts co-occur at many sites in the Aiken Plateau, sometimes overlapping spatially to produce relatively dense artifact distributions. The convention of cruciform shoveltesting on a 10-meter interval to delineate site boundaries often results in relatively large site dimensions for amalgams of unrelated prehistoric artifact clusters. Natural physiographic and hydrologic features such as those in the project area often assume natural boundaries to otherwise continuous distributions of overlapping clusters.

In addition to testing previous sites, subsurface testing was conducted along transects following the road and utility rights-of-way to locate new sites. One new site (38AK466) was documented in this effort.

Archaeological survey methods involved pedestrian coverage of exposed surfaces and subsurface testing primarily along linear transects. Standard survey methods established in 1989 (SRARP 1990:15-16) were followed during fieldwork. The survey was conducted by a crew composed of two to four archaeologists. Since the project area is completely wooded, shovel tests excavated along transects were used to locate sites and delineate boundaries. Survey transect azimuths were established with a compass and spacing between shovel tests was determined by crew members stepping off distances in approximate meter length strides. Shovel tests, measuring $35 \times 35 \mathrm{~cm}$, were excavated to a depth of $80 \mathrm{~cm} \mathrm{BS}$ or until sterile, gravelly clay substrate was encountered. All soil was passed through 0.25 in $(0.64 \mathrm{~cm})$ wire mesh, and artifacts were collected and bagged 
according to shovel test number. The location, contents, and depth of each shovel test were recorded on SRARP Shovel Test Forms. Provenience data for all shovel tests are presented in Appendix A.

Survey of the Project Area. In anticipation of the potential for extensive, buried cultural deposits at site 38AK289 in the major portion of the project area, a method of systematic shovel testing along linear transects was employed. Figure 15 illustrates the location of all transects and associated shovel tests resulting from this initial stage of subsurface testing. An old fence post located on the north side of the access road was selected as a datum. Fieldwork began with the excavation of shovel tests along ten transects (Transects 1-10) that were spaced $30 \mathrm{~m}$ apart and oriented in an approximately north to south direction. Shovel tests were excavated at $30 \mathrm{~m}$ intervals along these transects, beginning along the eastern boundary of the project area (the terrace edge of Upper Three Runs) and proceeding east across the landform to the ridge top, where the frequency of artifacts dropped precipitously.

Altogether, 132 shovel tests pits (STPs) were completed in this manner. Of the 105 STPs excavated along Transects $1-8$, the majority were positive $(n=65 ; 62 \%)$ with a noticeable decrease in the occurrence of positive STPs along Transects $9(n=2)$ and 10 $(n=1)$. With positive STPs having reached a point of diminishing returns along northsouth transects at about $250 \mathrm{~m}$ east of the terrace edge, the orientation of testing was shifted to the ridge spine. Transect 11 began at a point $30 \mathrm{~m}$ southwest of STP 12 on Transect 10. Out of nine STPs dug, only one (STP 6) produced artifacts. Transects 12 and 15 began $30 \mathrm{~m}$ to the northwest and southwest, respectively, of STP 4 on Transect 10 and continued until the excavation of two consecutive negative STPs. Artifacts were recovered from only one STP on each of these transects.

Prior to the results of this testing stage, 38AK289 was characterized as having historic and prehistoric components based on standing structural remains and artifacts recovered from looting activities. As no subsurface testing was done at 38AK289 at the time of initial discovery or subsequent visits, site dimensions were only roughly estimated at $100 \times 100 \mathrm{~m}$. The STPs excavated in the project area showed no distinct spatial separation of artifact deposits between the terrace edge where 38AK289 is located and Transect 8. Based on these findings, the boundaries of $38 \mathrm{AK} 289$ have been expanded to include all positive STPs on the landform. The isolated positive tests on the ridge top are also included in the new site parameters because of their occurrence on the same landform and proximity to the major concentration of artifacts. Additional work consisting of closer interval STPs and test unit excavations was conducted at 38AK289. The results of this intensive testing discussed in detail in Chapter 4.

Survey of the Project Area Rights-of-Way. Shovel testing was also employed to examine outlying areas of proposed impact, namely the access road and utility easement. Improvements to the present project area access road (SRS 219) include clearing a $122 \mathrm{~m}$ wide easement beginning at Phelps Road. To verify that no buried archaeological sites were located in the proposed easement, 22 STPs were excavated approximately $10 \mathrm{~m}$ south of road 219 along Transect 18 (Figure 16). No evidence for either prehistoric or historic occupations were found in these tests. 


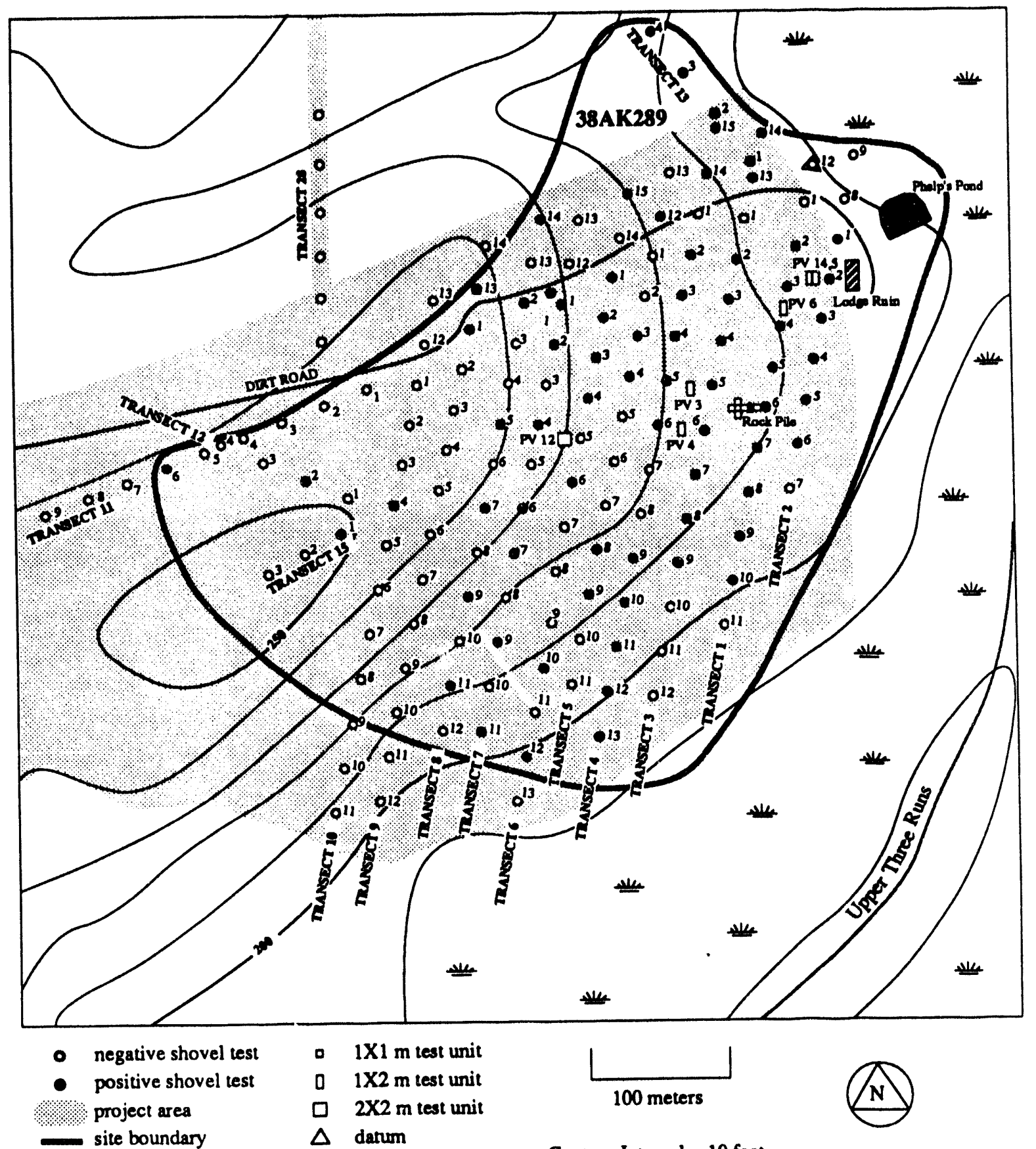

Contour Interval = 10 feet

Figure 15. Map of 38AK289 showing location of shovel test transects and test units. 


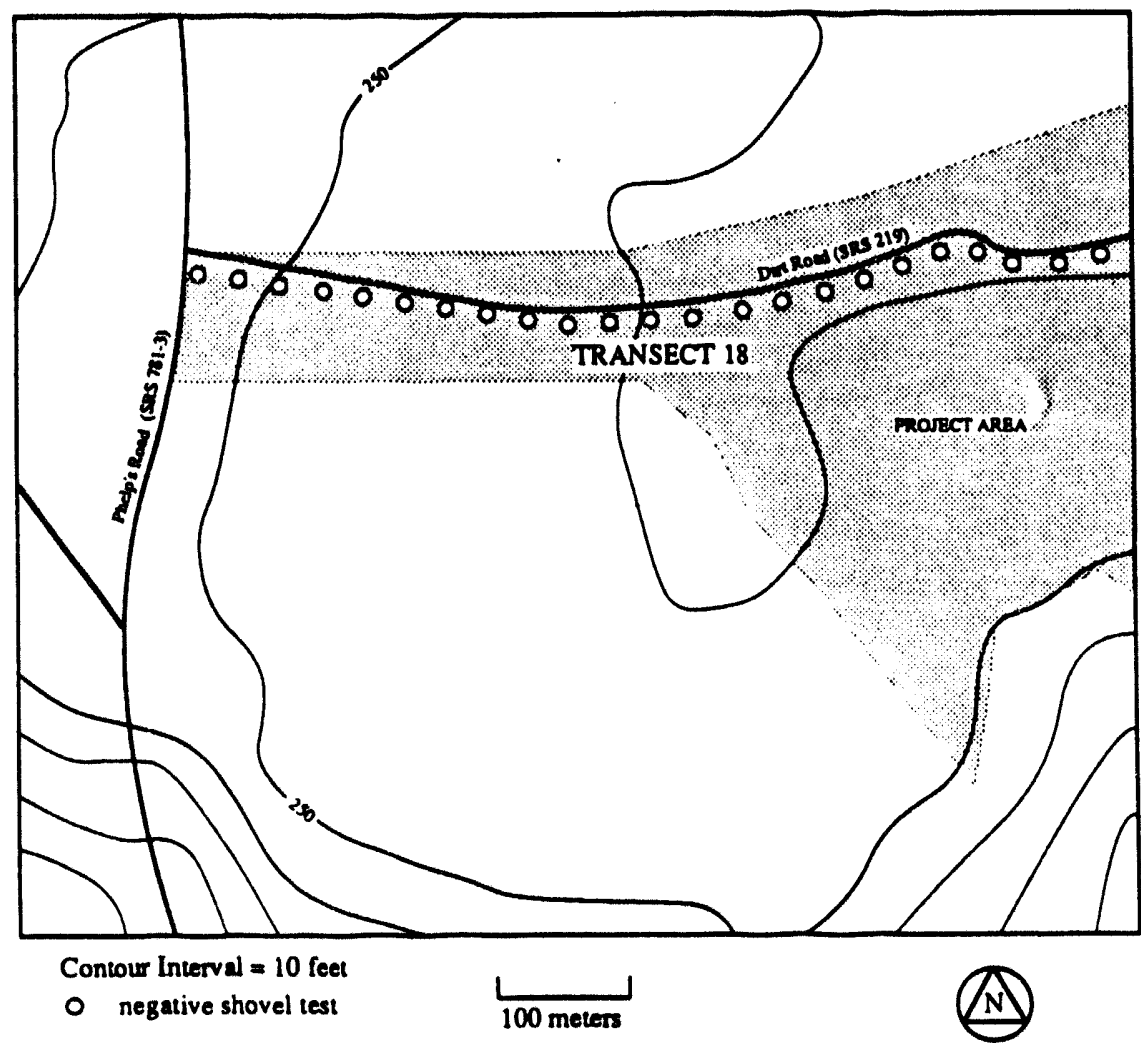

Figure 16. Location of shovel test Transect 18 in access road right-of-way of project area.

Shovel test transects were likewise used as a means of locating sites along the utility easement. As explained earlier, the proposed utility right-of-way was relocated after most of the fieldwork had been completed along an original right-of-way. The initial design fronted the floodplain of Upper Three Runs, following the terrace edge from the project area to the SRS property boundary. The subsequent location originates on the northern project boundary at about $400 \mathrm{~m}$ west of the floodplain and runs directly north for $1,450 \mathrm{~m}$ to the SRS property line. Because of this change, the potential impacts to cultural resources along the terrace edge have been eliminated. The following description, however, presents the methods of fieldwork conducted along the originally proposed utility easement as well as the work completed along the relocated line.

Because both of the proposed utility easements had relatively narrow widths of only seven meters, single shovel test transects were used on each to test for buried cultural materials. Transect 13 followed the original easement in a northeast direction, beginning at a point about $30 \mathrm{~m}$ from the project area datum (Figures 15 and 17). Eighteen STPs were eventually excavated along this line with nine yielding artifacts. The first four tests (STPs 1-4) were positive and are therefore included within the site boundaries of 38AK289. Three negative STPs (STPs 5-7) were dug before artifacts were again encountered, leaving a $120 \mathrm{~m}$ horizontal separation between $38 \mathrm{AK} 289$ and the next four positive STPs, which actually intercepted a previously recorded site, 38AK287. These latter STPs were subsequently renumbered, and the artifacts incorporated into the 38 AK 289 provenience data. Further information on 38AK289 is provided in Chapter 4. The only other positive STP along Transect 13 was STP 10, located about 90 m north of 38 AK 287, which produced one small flake. Because the right-of-way was relocated away from this isolated find, further testing for site definition was not conducted and it is herein recorded as Occurrence 1. 


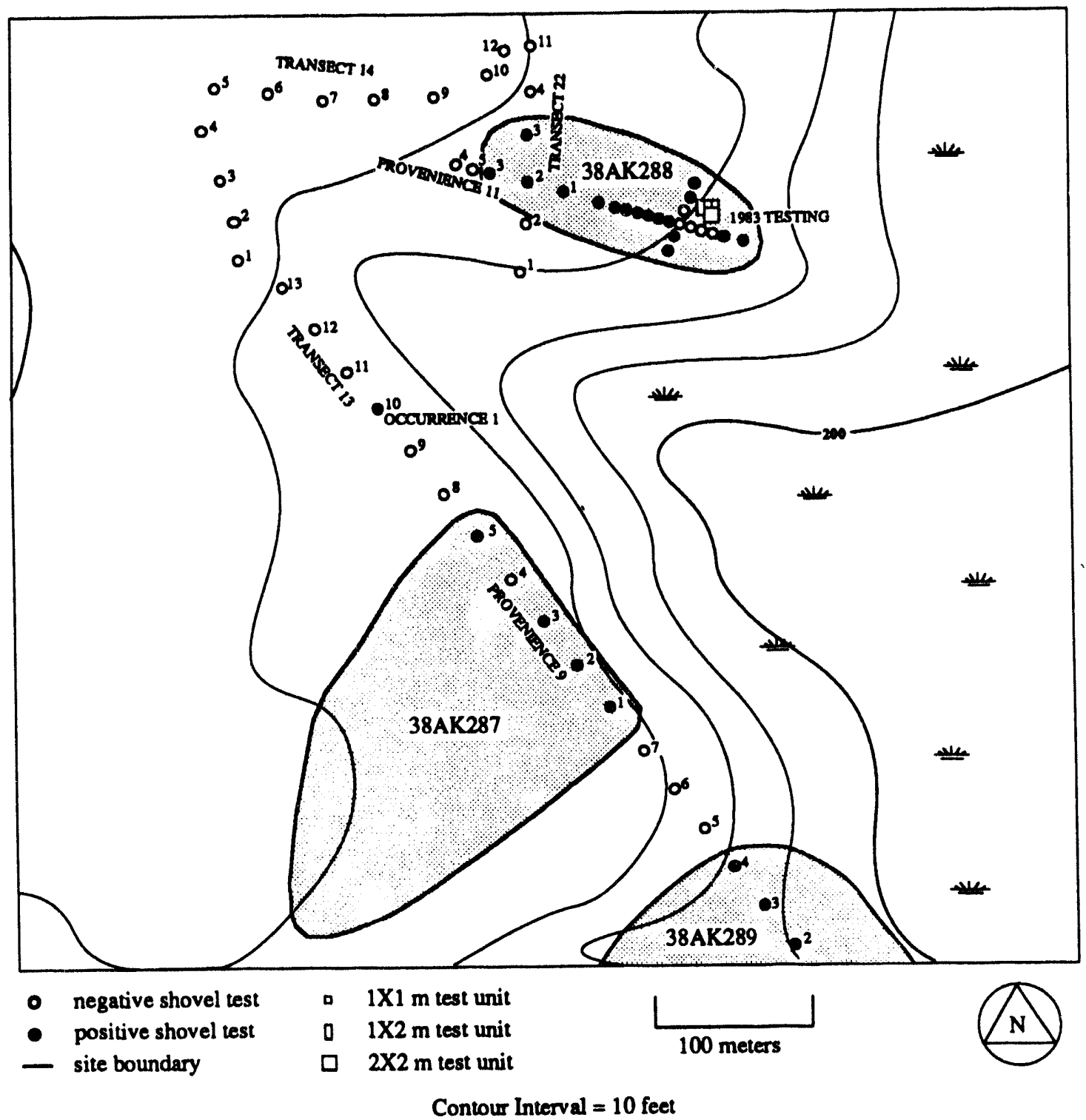

Figure 17. Locations of shovel test Transects 13,14, and 22, and Provenience 11 along the origin location of utility easement.

At this point in the transect survey, the exact location of the original utility easement was not marked in the field, and the design map was insufficient to maintain an semblance of survey accuracy. Thus, it was decided to follow the contour of the terrace edge where the probability of intercepting sites, previously recorded and otherwise, was greatest. The existence of an old firebreak aided in this effort. Transect 14 was established along this line (Figure 17) and circumvented the springhead of an intermittent drainage for a few hundred meters. Surprisingly, none of the 12 STPs along this transect yielded artifacts. 
On the north side of the springhead, a short transect of five STPs (Transect 22) was oriented southward in the hopes of intercepting 38AK288. Although a cruciform pattern of shovel tests was dug at the site in 1983 (one year after the site was recorded), site boundaries had not been properly defined according to established SRARP procedures (SRARP 1990:15-16). To delineate more accurately the western extent of 38AK288, where the original easement should have crossed, shovel tests were excavated in a northwest direction beginning at a point $20 \mathrm{~m}$ from the last shovel test dug in 1983. (Fortunately, the old STPs were still visible because they were not routinely backfilled in the early years of the SRARP.) The tests were dug on a line designated Provenience 11, as earlier work assigned provenience numbers 1-10 to test units. Three of the tests were positive, allowing us to expand the site dimensions of 38AK288 to 200x75 m. Despite this expanded boundary, 38AK288 lies well outside the impact of the relocated utility easement.

To the north of $38 \mathrm{AK} 288$ along the original utility easement, limited shovel testing was conducted in three specific areas along Transects 26, 27, and 30 (Figure 18). The purpose of this work was to locate new or previously recorded sites along the terrace edge in the vicinity of the easement. Transect 26, located about $75 \mathrm{~m}$ south of the SRS boundary line, consisted of four negative STPs along the northern edge of an intermittent drainage. Transect 27 consisted of four negative STPs parallel to the terrace edge beginning just south of the same intermittent drainage. Transect 30 consisted of a cruciform pattern of STPs about $600 \mathrm{~m}$ south of the SRS boundary in an area where two pieces of chert were surface collected. Twelve STPs were dug with only one test producing a single flake. These three pieces of debitage were designated Occurrence 2.

As work along the original utility easement progressed, SRARP negotiated with SREL personnel to relocate the footprint for the proposed Conference Center some $100 \mathrm{~m}$ upslope and away from significant archaeological deposits at 38AK289. This alteration caused the design team to also relocate the utility easement away from the terrace edge. Fieldwork in this area was thus halted and redirected toward more thorough testing of the new footprint (see section on 38AK289 in Chapter 4 for these methods and results), and along the relocated easement. A single line of STPs, designated Transect 28 (Figure 18), was oriented along the new easement beginning at SRS Road 219 and ending at the SRS boundary. Transect 28 intercepted the western margin of a previously recorded site, 38AK287, and one new site, 38AK466. Altogether, 51 shovel tests were dug on Transect 28 some of which were later renumbered and included in the provenience data for sites 38 AK287 and 38AK466.

Secondary Testing. Finally, site testing at 38AK289 and 38AK287 involved the excavation of several controlled test units. A variety of $1 \times 1 \mathrm{~m}, 1 \times 2 \mathrm{~m}$ and $2 \times 2 \mathrm{~m}$ units amounting to $19 \mathrm{~m}^{2}$ were excavated at 38AK289, and three contiguous $1 \times 2 \mathrm{~m}$ units were excavated at 38AK287. The test units were oriented to cardinal directions and, unless otherwise specified, excavated in $10 \mathrm{~cm}$ arbitrary levels until two consecutive culturally sterile levels occurred. All soil was screened through 0.25 in $(0.64 \mathrm{~cm})$ wire mesh, and artifacts were collected and bagged by level. The contents, depth, and other relevant information concerning each level was recorded on SRARP Test Unit Forms. Upon the completion of individual or adjoining test units, scaled drawings and photographs were made of one profile. 


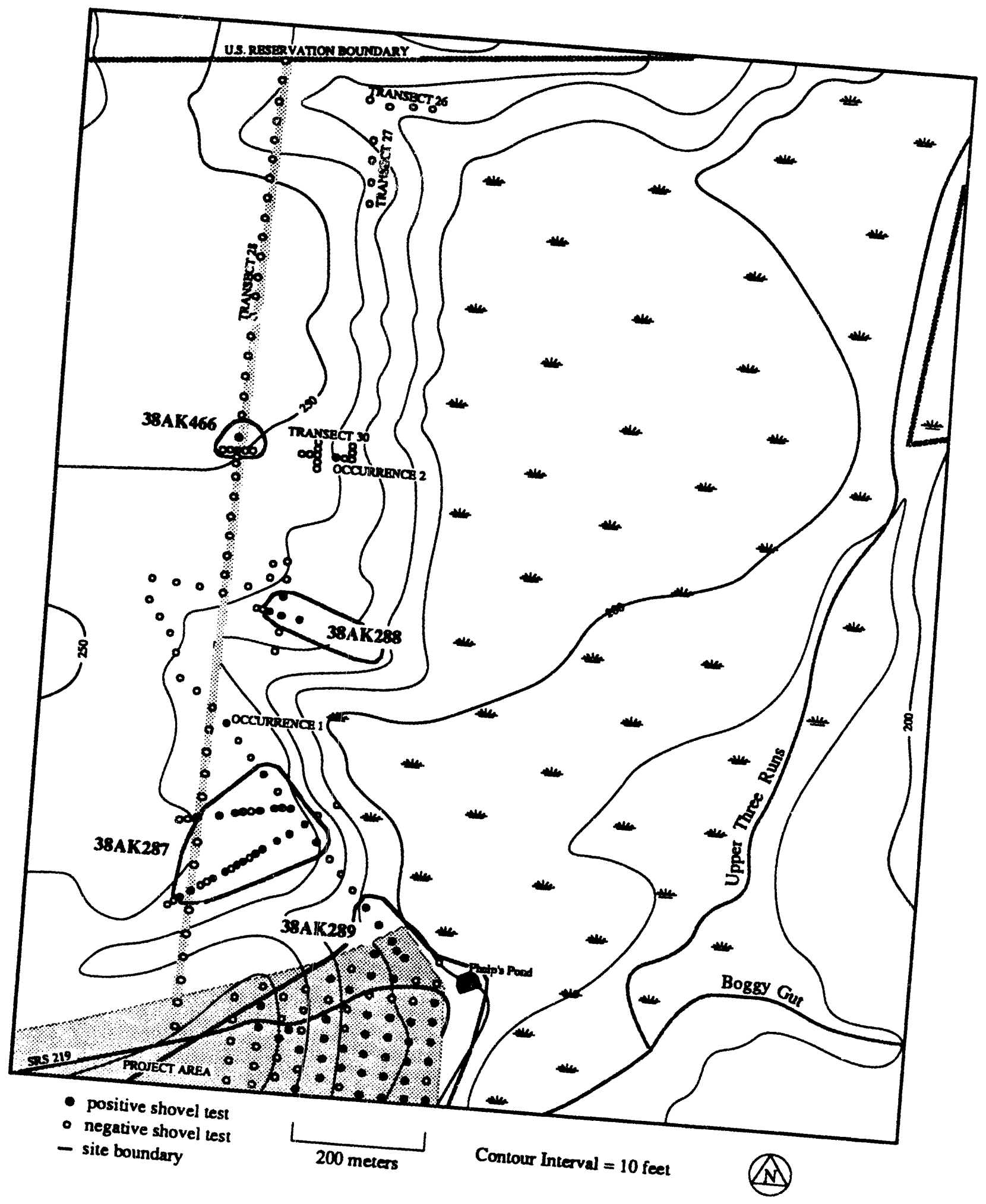

Figure 18. Locations of shovel test Transects $26,27,28$, and revised locations of utility easement 30 along the original and 


\section{CHAPTER 4 \\ SURVEY RESULTS}

The results of fieldwork and laboratory analysis are presented in this chapter. Within the project area one new site was located (38AK466) and two previously recorded sites (38AK287 and 38AK289) were revisited. Four other sites (38AK274, 38AK282, 38 AK 283, 38AK288) in the original, and subsequently modified, project area received some archaeological attention early in the project. Although these resources will not be affected by proposed construction, this chapter includes full documentation of the field investigations conducted at the sites.

A South Carolina State Site Form was completed or updated for each of the sites and filed at the Savannah River Archaeological Research Program (SRARP) laboratories at the Savannah River Site (SRS). Duplicate files are stored at the South Carolina Institute of Archaeology and Anthropology in Columbia.

Methods used to identify and analyze prehistoric artifacts from the SRS are fully described elsewhere (Sassaman et al. 1990:133-141) and need not be repeated here. All artifacts are curated at the SRARP Central Curation Facility (CCC). All shovel test and test unit provenience data are presented in Appendix A. Artifact inventories for sites 38AK289 and 38AK287 are provided in Appendices B and C, respectively; inventories for other sites appear as tables in the sections that follow.

The results of survey are divided into two sections: sites located within the area of direct impact from the proposed SREL Conference Center, and sites located outside the area of direct impact.

\section{SITES WITHIN THE AREA OF DIRECT IMPACT}

\section{AK289: Results of Field Investigations}

Site 38AK289 is situated on a prominent landform sverlooking the floodplain along the western margin of Upper Three Runs Creek, just upposite the confluence with Boggy Gut Branch (Figures 7 and 15; Table 1). The site occupies portions of an upland ridge top, ridge side slope, and river terrace edge at an elevation ranging from 200-250 ft AMSL. Site 38AK289 is bordered on the north by an intermittent Rank 1 stream and on the south by the alluvial floodplain. Dirt road SRS 219 provides access to the site. The dominant vegetation is pines, which, except for periodic harvesting, have covered the landform since at least the early twentieth century.

Table 1. Specifications for Site 38AK289.

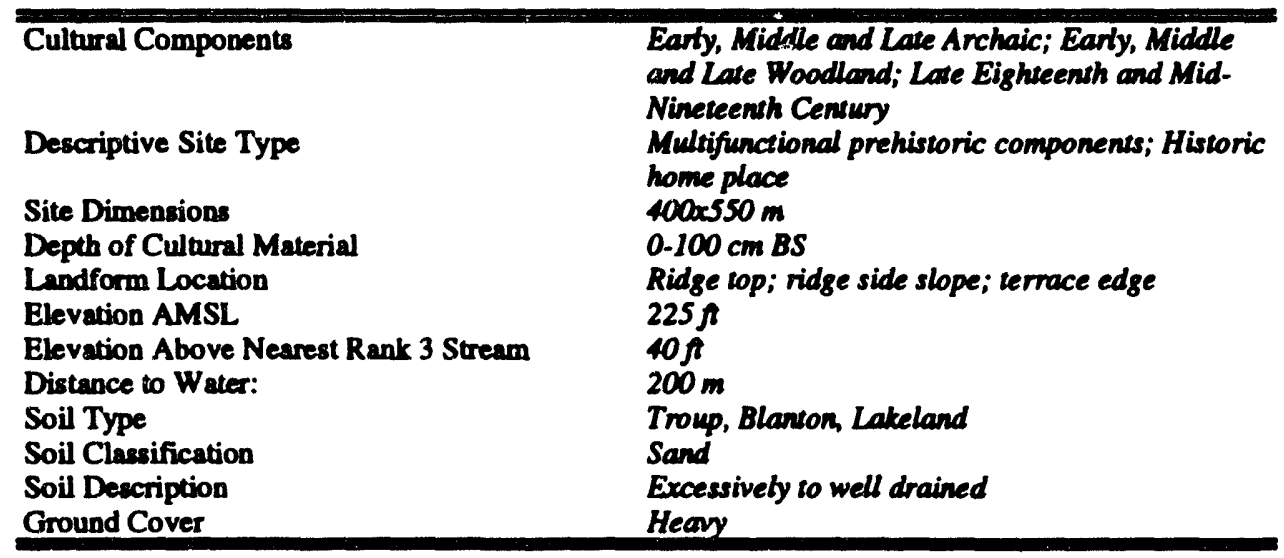


Surface exposure at 38AK289 is minimal due to the growth of pines and scrub vegetation along with pine straw litter. Subsurface testing demonstrated that archaeological remains extend across the terrace edge and ridge slope, diminishing substantially in density over the ridge top. Site dimensions of $400 \times 550 \mathrm{~m}$ are indicated on the basis of subsurface material. The site area, approximately $220,000 \mathrm{~m}^{2}$, generally conforms to the shape of the landform.

Components of 38AK289 include evidence for prehistoric occupations dating to the Early Archaic through the Late Woodland periods, and possibly the Early Mississippian period. Historic period land use began as early as 1793 according to early legal documents (see Chapter 2). Cultural material is confined to the site boundaries as defined during this project, with buried lithic debris distributed across the site in varying densities and historic remains located in discrete areas. The extensive prehistoric components likely represent repeated occupations due to the accessibility of water, mesic terrace and bottomland resources. The historic occupations most likely represent economically based changes in land use such as (1) cattle ranching and/or subsistence farming in the eighteenth century, (2) market agriculture production in the nineteenth century, (3) recreational sport hunting activities in the first half of the twentieth century, and finally (4) commercial timber management and harvesting since the mid-twentieth century.

The typical soil profile of 38AK289 to a depth of two meters contains five recognizable zones (Figures 19 and 20). However, discrete soil strata below the topsoil layer are indistinguishable due to intergradations of soil colors. From the surface to a depth of $20-25 \mathrm{~cm}$ BS is a very dark grayish brown (10YR3/2) silty-fine sandy loam topsoil. Contact with the underlying zone is sharp. In test units located on the terrace edge, this underlying zone consists of an amorphous stratum of mottled yellowish brown (10YR5/8) silty-fine sandy loam extending to about $35 \mathrm{~cm}$ BS. The composition of this zone is a result of organic leaching from the topsoil layer. No plowscars were detected below the topsoil in any test units, although agricultural plowing probably occurred at the site sometime during the historic period. Because 38AK289 was not in cultivation during most, if not all, of the twentieth century, the absence of plowscars also may be a result of leaching processes.

Underlying the zone of maximum leaching to about $100 \mathrm{~cm} \mathrm{BS}$ is a homogeneous yellowish brown (10YR5/6) silty-fine sandy loam. Below this zone to about $150-160 \mathrm{~cm}$ BS is a homogeneous strong brown (7.5YR5/6) silty-very fine sandy loam. From this depth to the base of the profile a mottled very pale brown (10YR7/3) and yellow (10YR7/6) fine sandy loam is present.

Archaeological deposits at 38AK289 have the highest density along the terrace edge. In this area, they are concentrated in the upper $80 \mathrm{~cm}$ of the profile, although artifacts were retrieved from depths as great as $100 \mathrm{~cm}$ BS in test units. Diagnostic artifacts spanning the Early Archaic through the early twentieth century are stratified in the upper $80 \mathrm{~cm}$. Historic, probable Mississippian, and Late Woodland materials are confined to the topsoil layer $(0-20 \mathrm{~cm} \mathrm{BS})$; Middle and Early Woodland remains are concentrated in the subtopsoil sands from $20-35 \mathrm{~cm}$ BS; Late Archaic artifacts are found 40 to $60 \mathrm{~cm} \mathrm{BS}$; and Early Archaic tools are present in the $70-80 \mathrm{~cm}$ range. Cultural deposits are least dense on the ridge slope and, when encountered, are found between 70$80 \mathrm{~cm}$ BS. These deeply buried ridge slope deposits date exclusively to the Early Archaic period. 


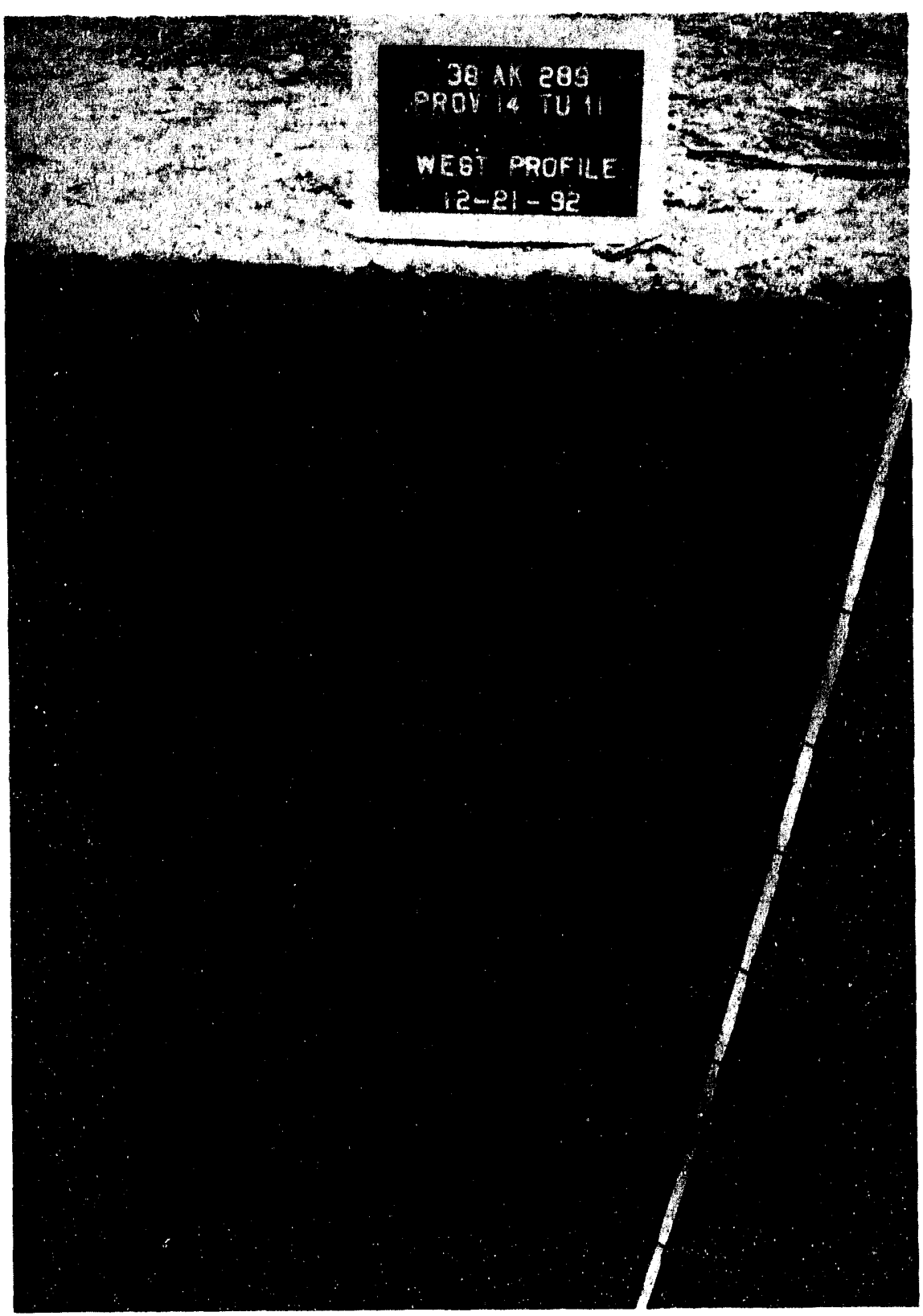

Figure 19. West profile photograph, Provenience 14, 38AK289. 


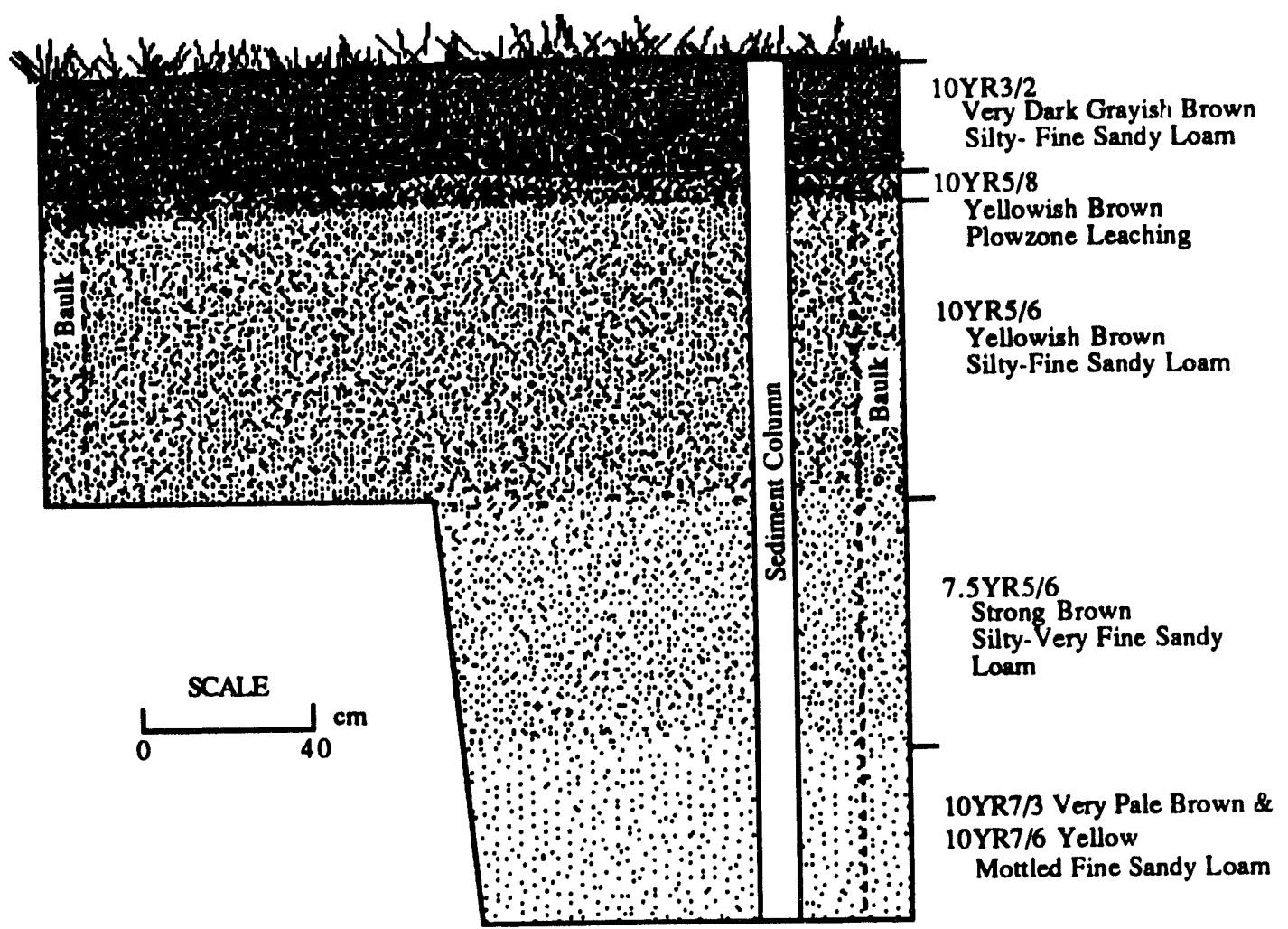

Figure 20. West profile drawing, Provenience 14, 38AK289.

Previous Survey. Site 38AK289 was first recorded in November of 1982 during a survey of Upper Three Runs Creek as part of the stratified, random SRS-wide survey (Sassaman et al. 1990). Based solely on extant historic features, 38AK289 was characterized as a late nineteenth to early twentieth century site. Members of the 1982 survey crew took a series of black and white photographs of these features and drew a scaled plan map of the site reproduced here as Figure 21. No surface collection was made and no subsurface testing was conducted. Site size was roughly estimated at $100 \times 100 \mathrm{~m}$.

According to the 1982 site form, 38AK289 contained the remnants of a single story structure (Figure 22) and a two-acre pond, locally known as Phelp's Pond, contained by an earthen dam (Figure 23). Standing architectural remains consists of a brick wall built into the terrace edge and double sided chimney, constructed of early twentieth century brick and ferruginous sandstone, located in the center of the structure. The crescent-shaped earthen dam is about $75 \mathrm{~m}$ long. A concrete flume, located about $15 \mathrm{~m}$ from the western end of the dam, exhibits bolts that possibly once held a mill wheel (Figure 24). A metal valve that functioned as an overflow control mechanism stands in the water about twenty meters northeast of the concrete flume. The pond's primary spillway, located on the eastern end of the dam, is an aesthetic piece of cement and brick workmanship (Figure 25). 


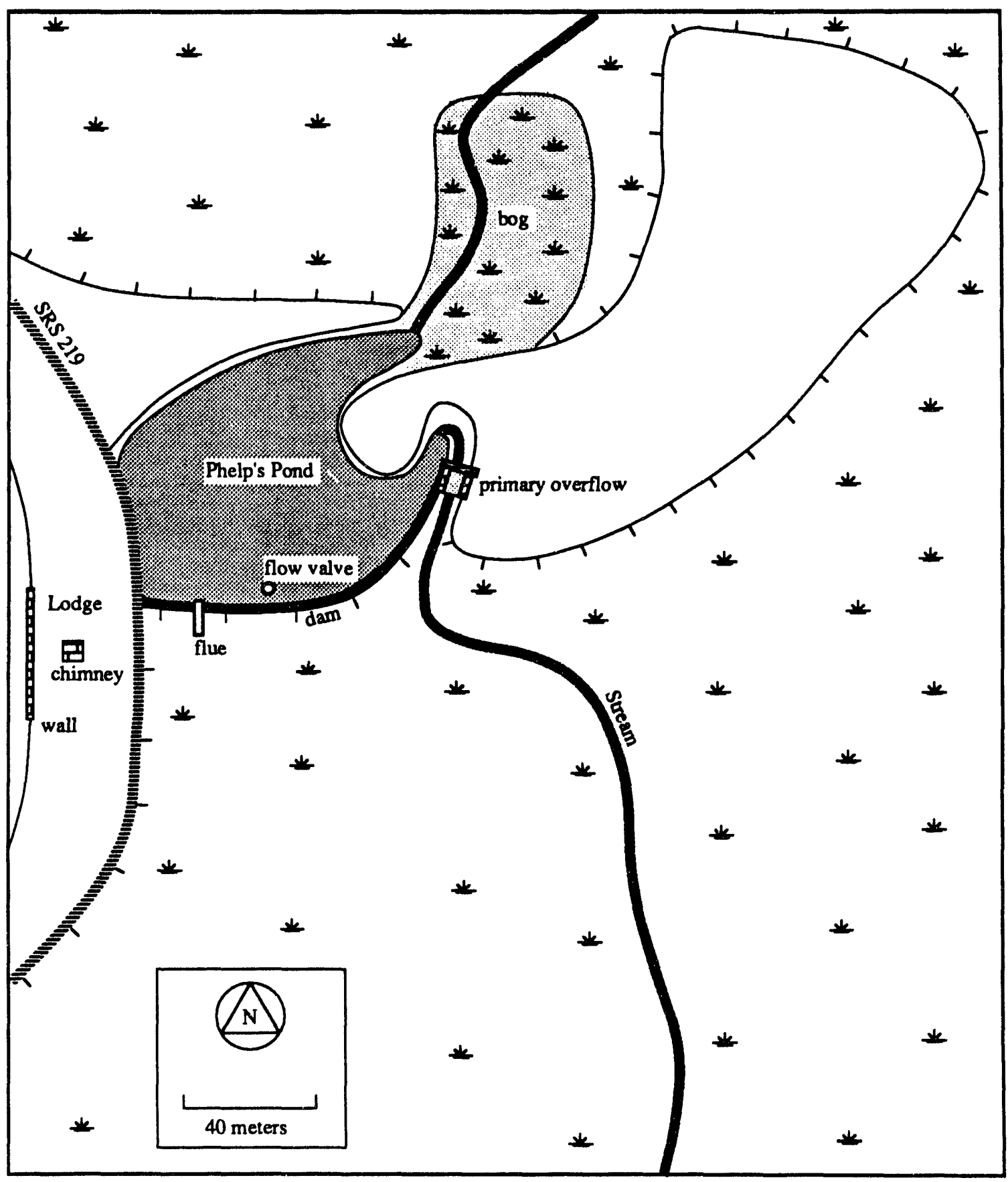

Figure 21. Sketch map of "Club House" remains and Phelp's Pond, 38AK289. 


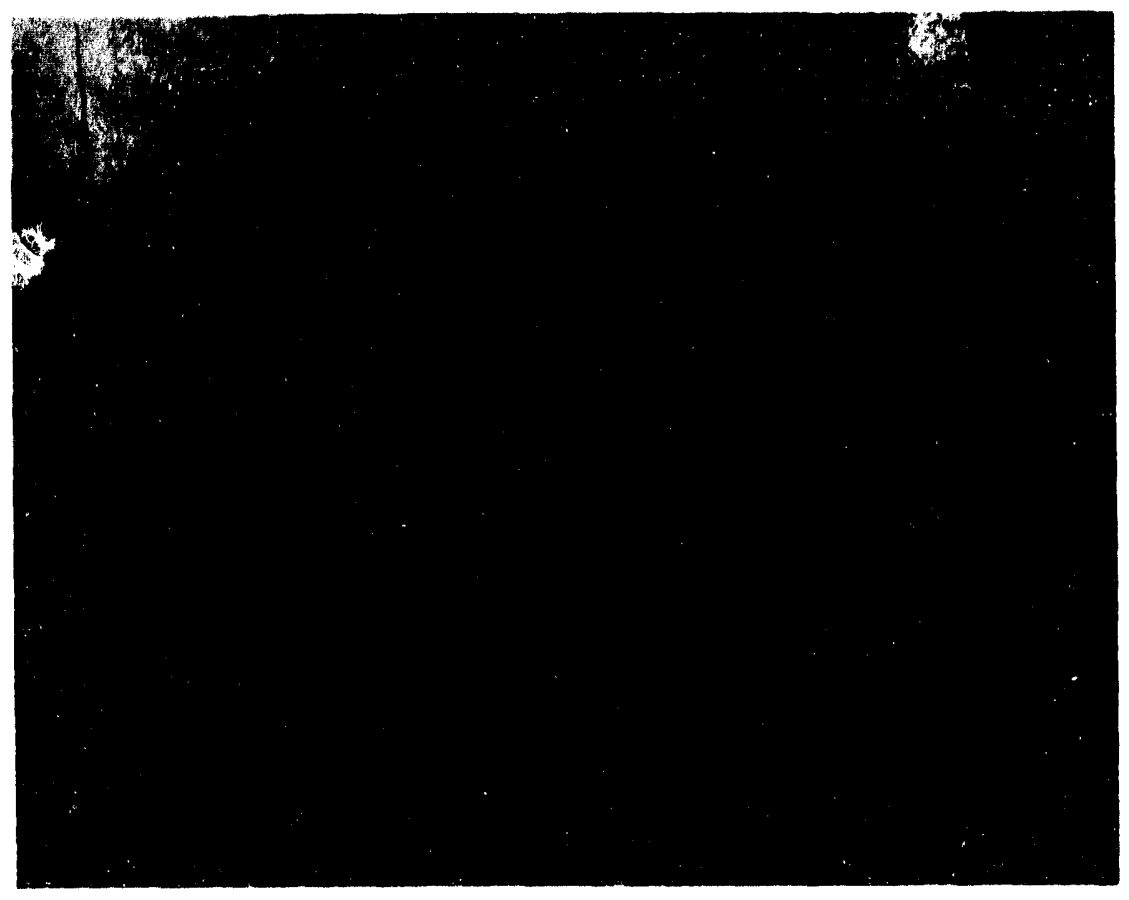

Figure 22. Architectural remains of "'Club House," 38AK289.

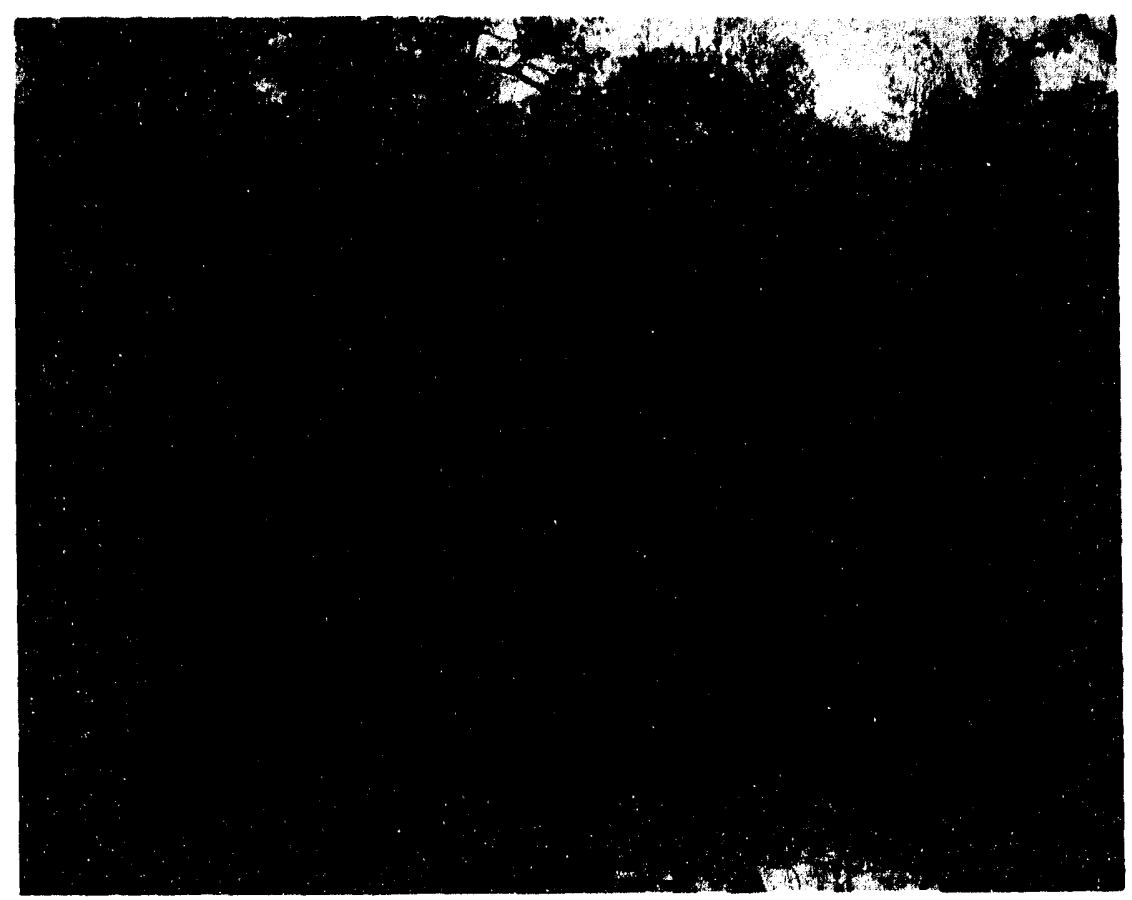

Figure 23. Phelp's Pond and earthen dam, 38AK289. 


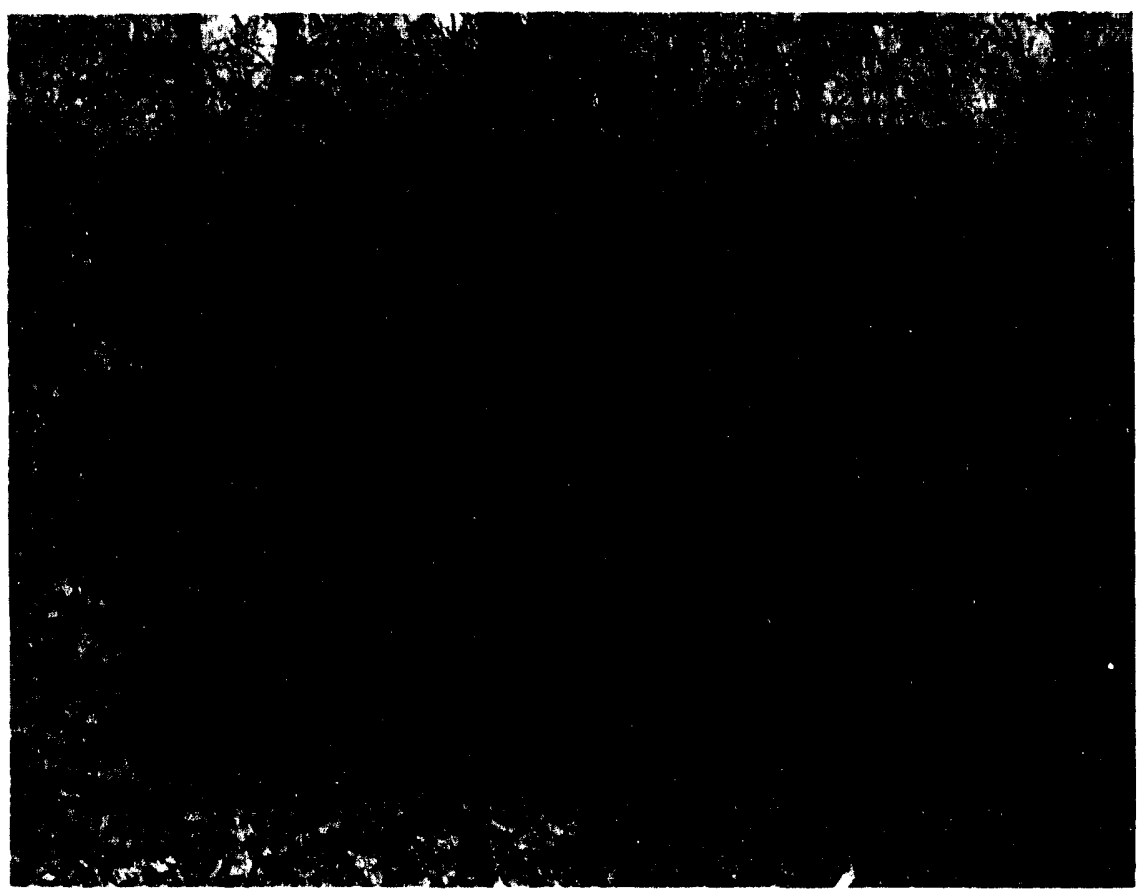

Figure 24. Earthen dam and concrete flume, 38AK289.

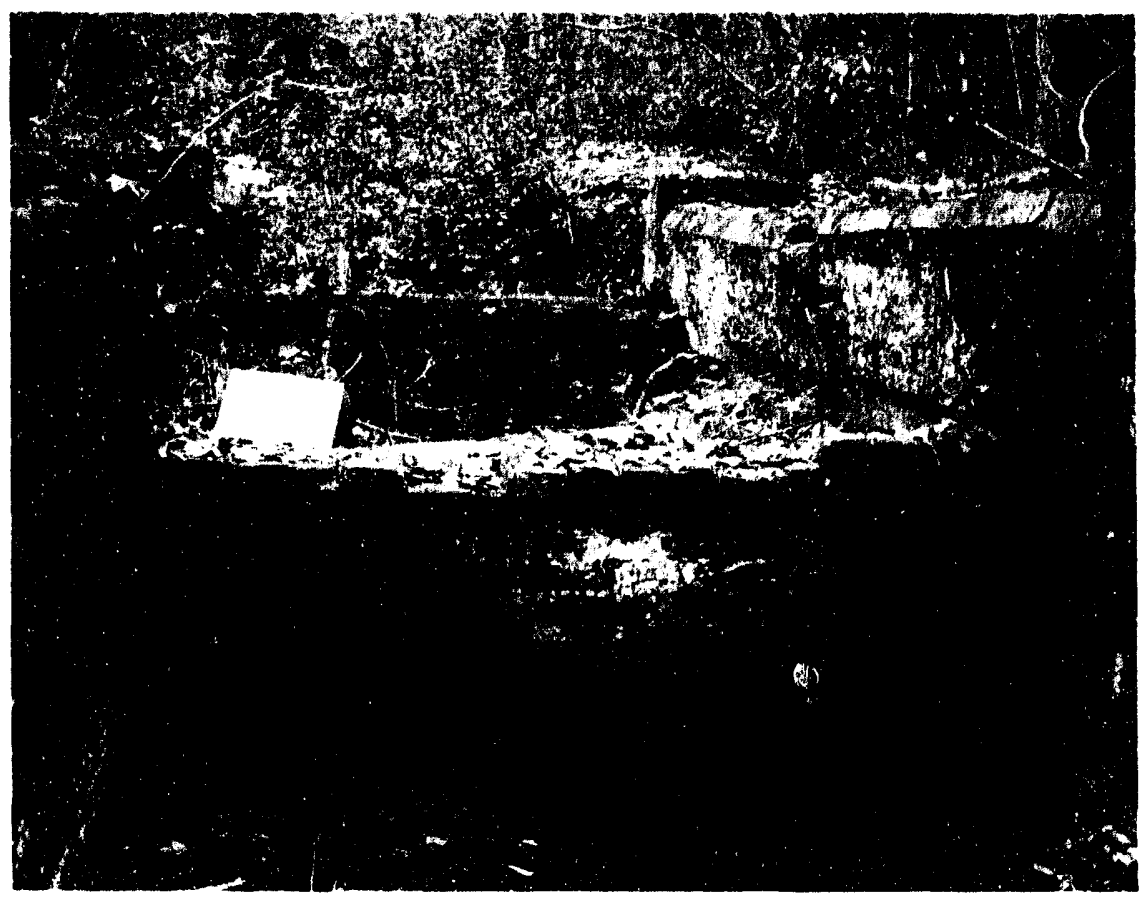

Figure 25. Primary spillway on located eastern end of Phelp's Pond dam, 38AK289. 
The actual purpose of the structure and pond is unknown, although the structure is thought to have served as a "Club House" associated with sport hunting activities during the first half of the twentieth century. The pond may have once serviced milling activities. An assessment of the current condition of the structure and dam was made during this survey. The structure is no more dilapidated now than in 1982 and the exterior of the dam is still in fairly good shape, although there are indications of substructure erosion where small cave-ins have occurred along the top. These features are included in a Department of Energy (DOE) Research Set-Aside and, as such, will be protected from forest management activities or other land-use impacts. DOE Set-Asides are contained within marked boundaries established by SREL personnel and serve to protect the natural (and cultural) resources of wetlands and adjacent terrace slopes (Charlie Davis, research coordinator for set-asides at the SREL, personal communication 1993).

In late 1989, SRARP personnel revisited 38AK289 after a report by SREL employee Charlie Davis of recent looter activity. An inspection of the area revealed several large potholes on the terrace edge directly behind the historic structure. The trespass violation and property damage on Federal lands was reported to the SRS Wackenhaut Security Service who immediately began patrolling the site. Soon thereafter, three men were apprehended in the act of digging for "Confederate gold" rumored buried in the area. According to Wackenhaut Incident Report Number 890196, the men confessed to having dug at the site on at least three occasions in the six months prior to their arrest. Due to extenuating circumstances, however, the men were not prosecuted, but instead reprimanded and ordered to relinquish all recovered artifacts in their possession to the SRARP and to backfill the holes. Although boundaries for $38 \mathrm{AK} 289$, as originally defined, contained only the structure and pond, the confiscated looters' material was provenienced under this site number and site boundaries were expanded $50 \mathrm{~m}$ westward. During a revisit to inspect the backfilled potholes in early 1990, a surface collection was made of all artifacts scattered in the backdirt. As described below, these collections contain mostly prehistoric material, including a Savannah River Stemmed biface.

1992-93 Investigations. Site 38AK289 was not visited again until August of 1992 when the investigations described in this report commenced. As noted, although the site had been recognized for ten years, it had received only limited archaeological attention. Therefore, systematic testing was necessary to derive information on the spatial extent of the site and on variation in artifact distribution. In short, shovel test data from transects across the landform within the project footprint demonstrated no distinct separation of artifacts from the terrace edge to the crest of the ridge slope. On the basis of this information, the site boundaries of 38AK289 were expanded to include all of this area.

After establishing the limits of artifact distribution, closer interval shovel tests and test units were employed to more fully examine buried cultural deposits at the proposed location of the Conference Center building, in areas of high artifact density, and in areas where historic remains were recovered or observed. Eighty-two shovel tests and eleven test units were excavated during these efforts.

As discussed in Chapter 1, the footprint of the originally proposed Conference Center building was located about $100 \mathrm{~m}$ west of the terrace edge. To assess the subsurface integrity and artifact density of this area of the site, two $1 \times 2 \mathrm{~m}$ test units, designated Proveniences 3 and 4, were excavated in approximately the center of the building footprint (Figure 15). Provenience 3 was placed $15 \mathrm{~m}$ west of STP 5 on Transect 3 and Provenience 4 was placed $30 \mathrm{~m}$ south of Provenience 3 . The soil profile of both units was similar to the profile illustrated in Figure 20, except that there was no 
leaching below the topsoil. Provenience 3 was excavated in $10 \mathrm{~cm}$ arbitrary levels to 100 cm BS, with artifacts recovered from Levels C-F (20-60 cm BS). Provenience 4 was also excavated in arbitrary $10 \mathrm{~cm}$ levels except for Level $\mathrm{C}$, which was dug as a $2 \mathrm{~cm}$ level to reach clean subsoil contact. The excavation of Provenience 4 was terminated at $122 \mathrm{~cm}$ BS with artifacts recovered from Levels C (20-22 cm BS) and E-K (42-102 cm BS). Based on the presence of artifacts in the upper levels of these test units, a decision was made by SREL personnel to relocate the Conference Center building footprint to another area, thereby avoiding adverse impacts to these near-surface deposits.

A location was selected on the ridge side slope about one hundred mexers to the west of the originally proposed footprint (Figure 2). Here, shovel test data from Transects 7 and 8 had demonstrated that cultural remains were less dense and not as shallow as deposits along the terrace edge. To examine more closely the immediate area of the footprint relocation, 43 shovel tests were excavated inside and around the $70 \times 70 \mathrm{ft}$ $(21 \times 21 \mathrm{~m})$ building footprint. This was in addition to the six shovel tests previously dug in the area along Transects 7 and 8 (Figure 26). These shovel tests were spaced $10 \mathrm{~m}$ apart, forming a grid designated Transect 25 that covered $60 \times 60 \mathrm{~m}$ area. Of the 49 shovel tests in the grid, 18 were positive, with 16 producing prehistoric artifacts, and two yielding a single historic artifact from the $20 \mathrm{~cm}$ thick topsoil layer. A total of 30 prehistoric artifacts were recovered in the 16 positive tests. The artifacts occurred from 30 to $100 \mathrm{~cm} \mathrm{BS}$, with the majority $(n=24)$ originating at about $80 \mathrm{~cm}$ BS.

In addition to shovel testing, a $2 \times 2 \mathrm{~m}$ test unit, labelled Provenience 12, was laid out around STP 2 of Transect 25 . This was the only shovel test that produced a diagnostic artifact (the base of a Kirk Corner Notched biface). The soil profile of Provenience 12 was similar to the profile illustrated in Figure 20, with the exception that there was no leaching below the topsoil. This test unit was dug to $130 \mathrm{~cm}$ BS, with artifacts recovered from Levels E-K (40-110 cm BS). Of the 67 artifacts recovered, most $(n=43)$ were from $80-100 \mathrm{~cm}$ BS, with the majority in Level I $(80-90 \mathrm{~cm}$ BS; $n=29$ including a Taylor Side Notched). This artifact density mode indicates that the Early Archaic occupational surface is about $85 \mathrm{~cm}$ BS. The surface most likely was buried by episodic colluvial deposits eroding from the ridge top. The vertical distribution of artifacts above and below the surface is attributed to various displacement agencies such as bioturbation (Brooks and Sassaman 1990:183).

Further subsurface investigations at 38AK289 consisted of intensive testing in areas of high artifact density and where historic remains were located or thought to be present. Along the terrace edge, testing was conducted in three specific locations. Figure 27 depicts the first location just west of the "Club House" remains. Testing involved two $1 \times 2 \mathrm{~m}$ units (Proveniences 5 and 14) and a cruciform pattern of shovel tests (Transects $19,20,21$, and 24). Proveniences 5 and 14 were adjoining test units that were placed about $15 \mathrm{~m}$ west of STP 2 on Transect 2 in an area where the highest density of pottery was detected during earlier shovel testing. The soil profile of Provenience 14 is illustrated in Figure 20. Provenience 5 was excavated in arbitrary $10 \mathrm{~cm}$ levels to a depth of $130 \mathrm{~cm}$ BS with artifacts recovered from Levels A-K $(0-100 \mathrm{~cm} \mathrm{BS})$. The components were well stratified in comparison with the component mixing evident at many Coastal Plain sites. Diagnostic artifacts followed a "temporal progression" from the late eighteenth century $(0-20 \mathrm{~cm}$ BS) to the Early Woodland $(30-50 \mathrm{~cm} \mathrm{BS})$, to the Late Archaic (50-60 cm BS), to the Early Archaic (70-80 cm BS).

Provenience 14 was excavated in $5 \mathrm{~cm}$ levels to a depth of $100 \mathrm{~cm}$ BS, with artifacts recovered from Levels A-O (0-85 cm BS). Further excavation of Provenience 14 consisted of removing soil from the northeast quadrant to a depth of $200 \mathrm{~cm}$ BS. Because no artifacts were recovered from $85-100 \mathrm{~cm}$ BS, the soil from this sub-unit excavation 


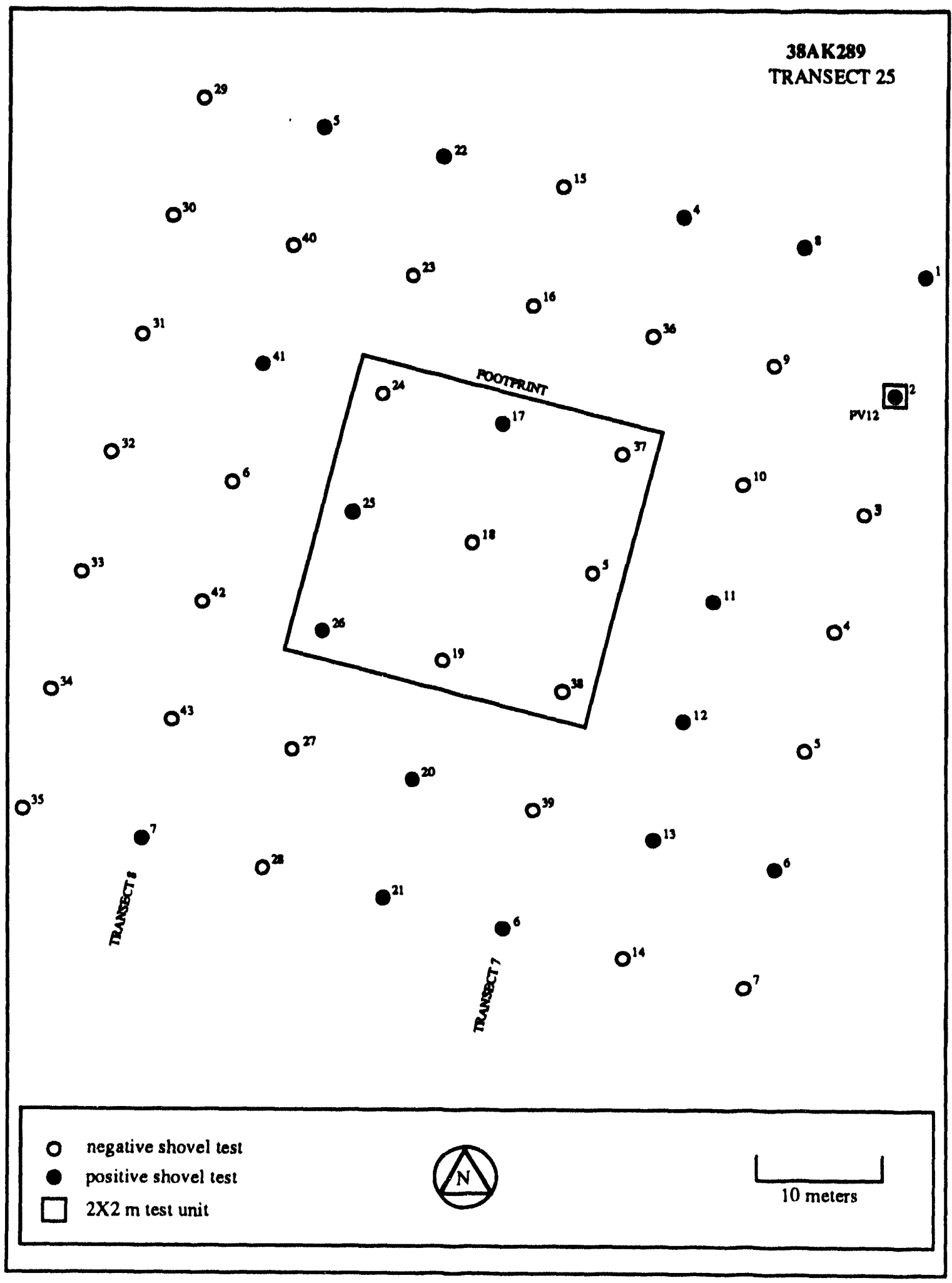

Figure 26. Location of shovel tests of Transect 25 in relocated footprint of Conference Center. 


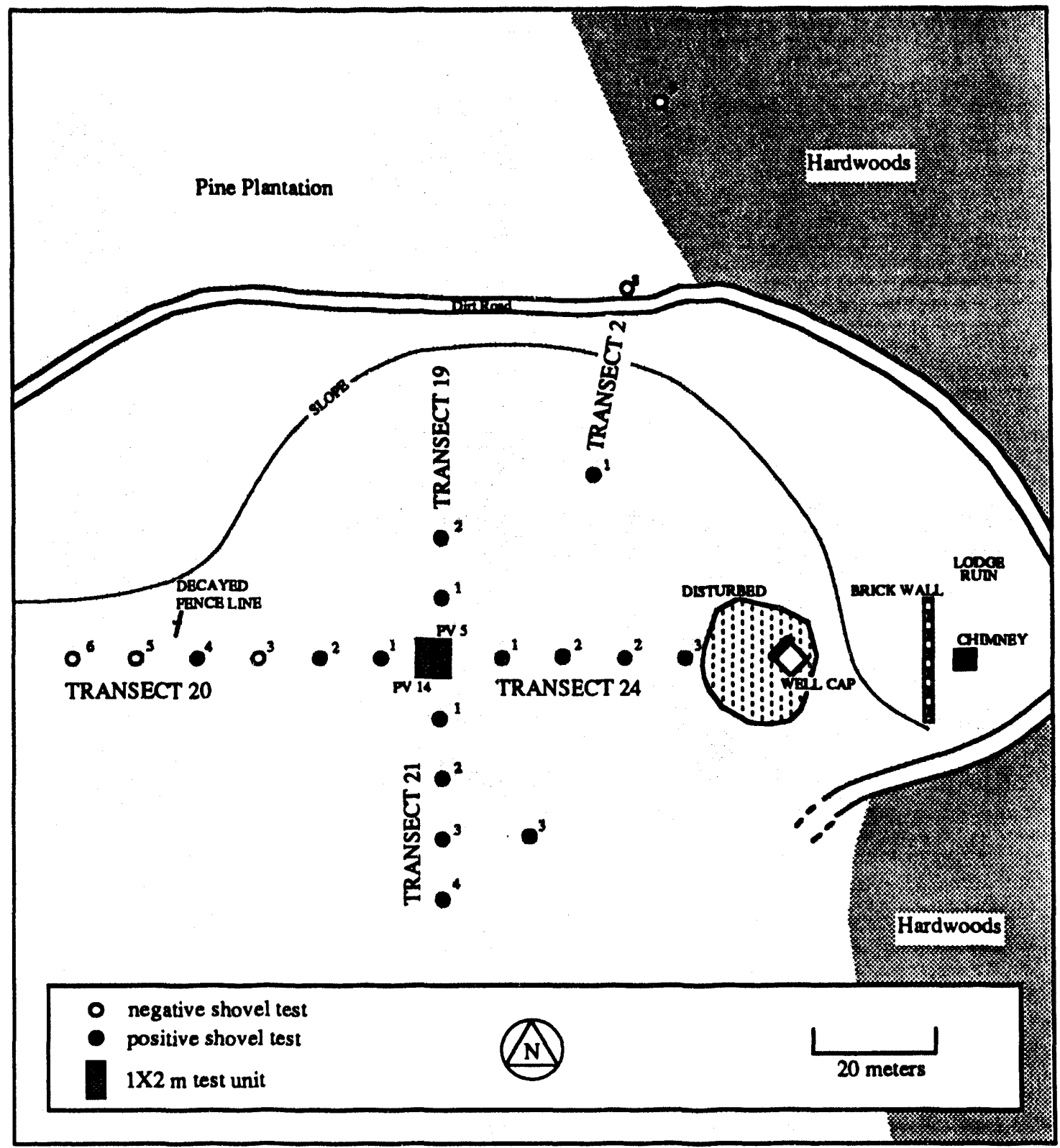

Figure 27. Northeast portion of 38AK289, showing locations of shovel tests, test units, and architectural remains of "Club House." 
was considered culturally sterile and therefore not screened. A continuous sediment column was collected in $5 \mathrm{~cm}$ increments, which correlates with the archaeologically excavated levels, to a depth of $2 \mathrm{~m}$ on the west profile (Figure 20). The resulting grainsize data, with the chronological controls provided by the archaeology, will be included in the regional sediment data base being compiled by Mark Brooks of the SRARP. It should be possible to derive sediment signatures, by depositional environment, that are sensitive to regional variation in Holocene climate (Brooks 1990; Brooks and Colquhoun 1991).

At about $67 \mathrm{~cm} \mathrm{BS}$, in Level L of Provenience 14, a circular soil stain, designated Feature 1, of mottled yellowish brown (10YR5/8) and dark yellowish brown (10YR3/4) sand was observed in the surrounding yellowish brown (10YR5/6) sand matrix. Located in the south half of Provenience 14, Feature 1 measured approximately $50 \mathrm{~cm}$ in diameter with its center situated $35 \mathrm{~cm}$ from the south profile and $50 \mathrm{~cm}$ from the west profile. The feature was pedestalled while soil from the remaining portion of the test unit was excavated and screened separately to a depth of one meter.

The north half of Feature 1 was sectioned in quadrants, with fill from the northeast quadrant collected and curated as a soil sample. Soil from the northwest quadrant was bagged for water screening. In cross-section, Feature 1 was $35 \mathrm{~cm}$ in depth and asymmetrical with curved sides and a rounded bottom (Figure 28). There was not a sharp distinction between the edge of the feature and the surrounding soil. Eventually, the fill from the south half was removed and, together with the soil from the northwest quadrant, was water screened through $1 / 8$ in $(.32 \mathrm{~cm})$ hardware cloth. This fine mesh screening resulted in the recovery of 31 flakes (most less than $100 \mathrm{~mm}^{2}$ in planview; 3.8 $\mathrm{g}), 1.1 \mathrm{~g}$ of charcoal flecks, five fragments $(0.7 \mathrm{~g})$ of burned clay, and $161.4 \mathrm{~g}$ of coarse sand. Buried prehistoric features are generally absent at Coastal Plain sites due to the acidity of the soil and rapid leaching of organic particles. Based on the rather well preserved quality of Feature 1, its point of origin at $67 \mathrm{~cm}$ BS, and its limited artifactual content, we suggest that its origin is a result of animal burrowing.

In addition to the test unit excavations in this locale, a cruciform pattern of shovel tests was excavated to delineate the spatial extent of the late nineteenth century component (Figure 27). This effort involved digging 15 tests spaced $10 \mathrm{~m}$ apart along Transects 19,20,21, and 24. Because the historic material was confined to the topsoil layer, shovel tests along Transects 19,20, and 21 were excavated to a depth of $30-35 \mathrm{~cm}$ BS, just below contact between the topsoil and the underlying lighter colored sands. Shovel tests along Transect 24 were excavated to a depth of $80-85 \mathrm{~cm}$ BS. Historic artifacts were recovered from STPs 2 and 4 along Transect 20, STP 2 along Transect 21, and STPs 1 and 3 along Transect 24, demonstrating that the component extent was about $30 \times 80 \mathrm{~m}$.

The sccond location investigated along the terrace edge was an area where previous shovel tests had yielded a high density of lithic debitage. A $1 \times 2 \mathrm{~m}$ test unit designated Provenience 6 was excavated $15 \mathrm{~m}$ south of STP 3 on Transect 1 (Figure 15). This unit was dug to a depth of $110 \mathrm{~cm}$ with artifacts occurring in Levels A-I $(0-90 \mathrm{~cm}$ BS). The soil profile was similar the profile illustrated in Figure 20.

The third location examined along the terrace edge was in the vicinity of an historic period rock pile observed by the survey crew during the initial transect shovel testing of the project area (Figure 15 and 29). The rock pile was about $5 \mathrm{~m}$ in diameter and consisted mostly of sandstone slabs along with bricks and mortar. This surface 


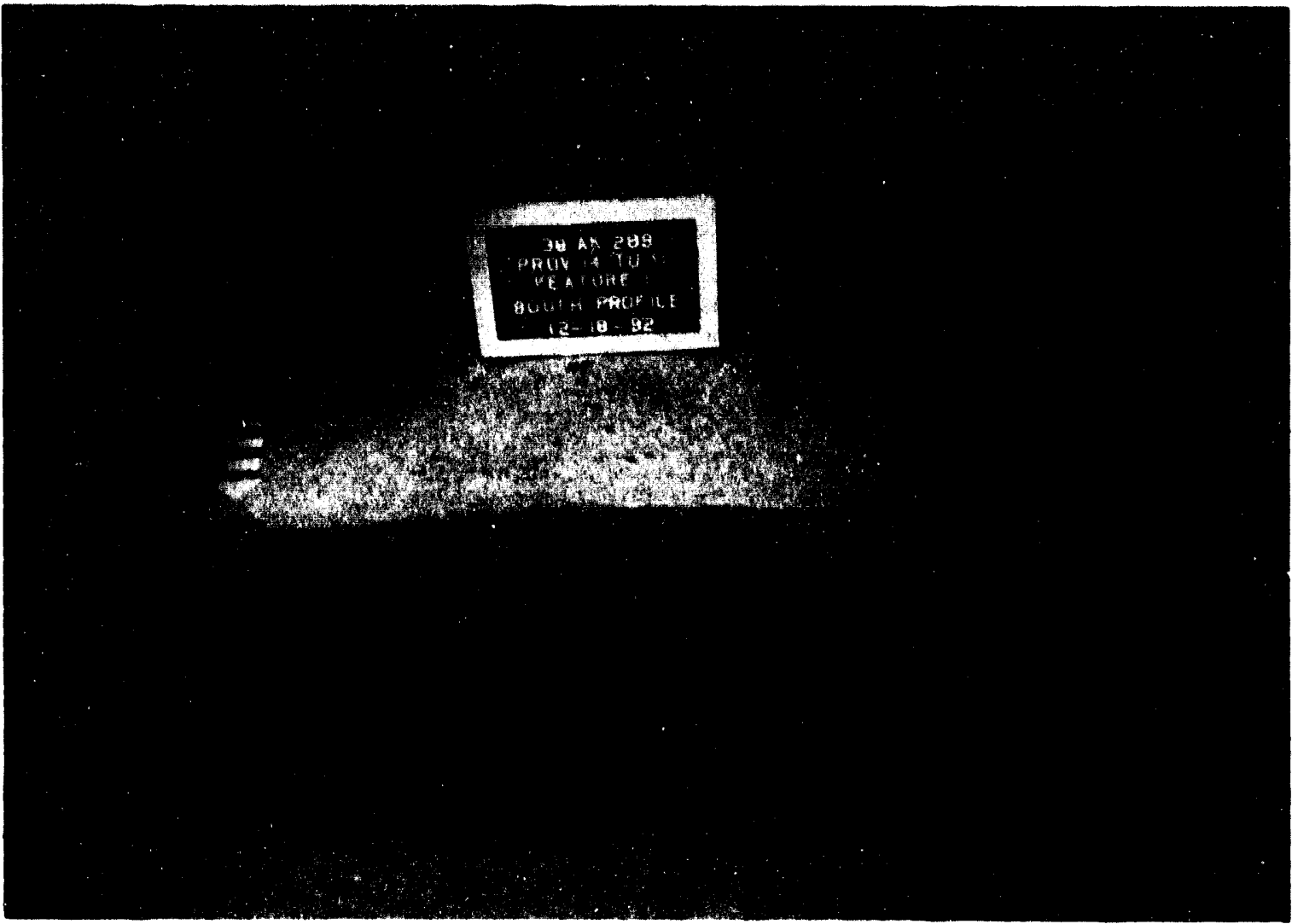

Figure 28. Cross-section of Feature 1, South Profile, Provenience 14, 38AK289.

feature was investigated to determine if it represented the remains of a razed structure. $A$ $1 \times 1$ test unit, labelled Provenience 7, was excavated on the eastem edge and immediately adjacent to the rock pile. The unit was dug to a depth of $40 \mathrm{~cm} \mathrm{BS}$. The soil matrix, which was similar to the profile illustrated in Figure 20, showed no indication of disturbance from razing or bulldozing activities and no historic artifacts besides brick fragments and mortar nodules were recovered. In a effort to locate any associated diagnostic historic artifacts around rock pile, a cruciform pattern of 11 shovel tests spaced 2.5 to $5 \mathrm{~m}$ apart was excavated along Transects 16 and 17 . These tests, however, produced only prehistoric material. Based on the absence of historic artifacts in the excavations, it appears that the rock pile is not a razed structure, but rather an secondary deposit of stone debris from elsewhere on the site.

The prehistoric assemblage recovered from these shovel tests contained a potsherd that indicated Early Mississippian period site use. To further examine the integrity of this likely component, four $1 \times 1 \mathrm{~m}$ test units (Proveniences 8-11) were excavated around STP 2. All units were excavated in arbitrary $10 \mathrm{~cm}$ levels with the exception of Level $C$ in Provenience 9, which was excavated as a $15 \mathrm{~cm}$ layer. Provenience 8 was excavated to $30 \mathrm{~cm} \mathrm{BS}$; Provenience 9 to $35 \mathrm{~cm} \mathrm{BS}$; and Proveniences 10 and 11 to $20 \mathrm{~cm} \mathrm{BS}$. Artifacts were recovered from all levels except Level A of Provenience 9. Only one small sherd from these test units had probable Mississippian period origins.

Intensive shovel testing was also conducted at the westem margin of 38AK289 on the ridge top where a mid-nineteenth century component was located during the initial 


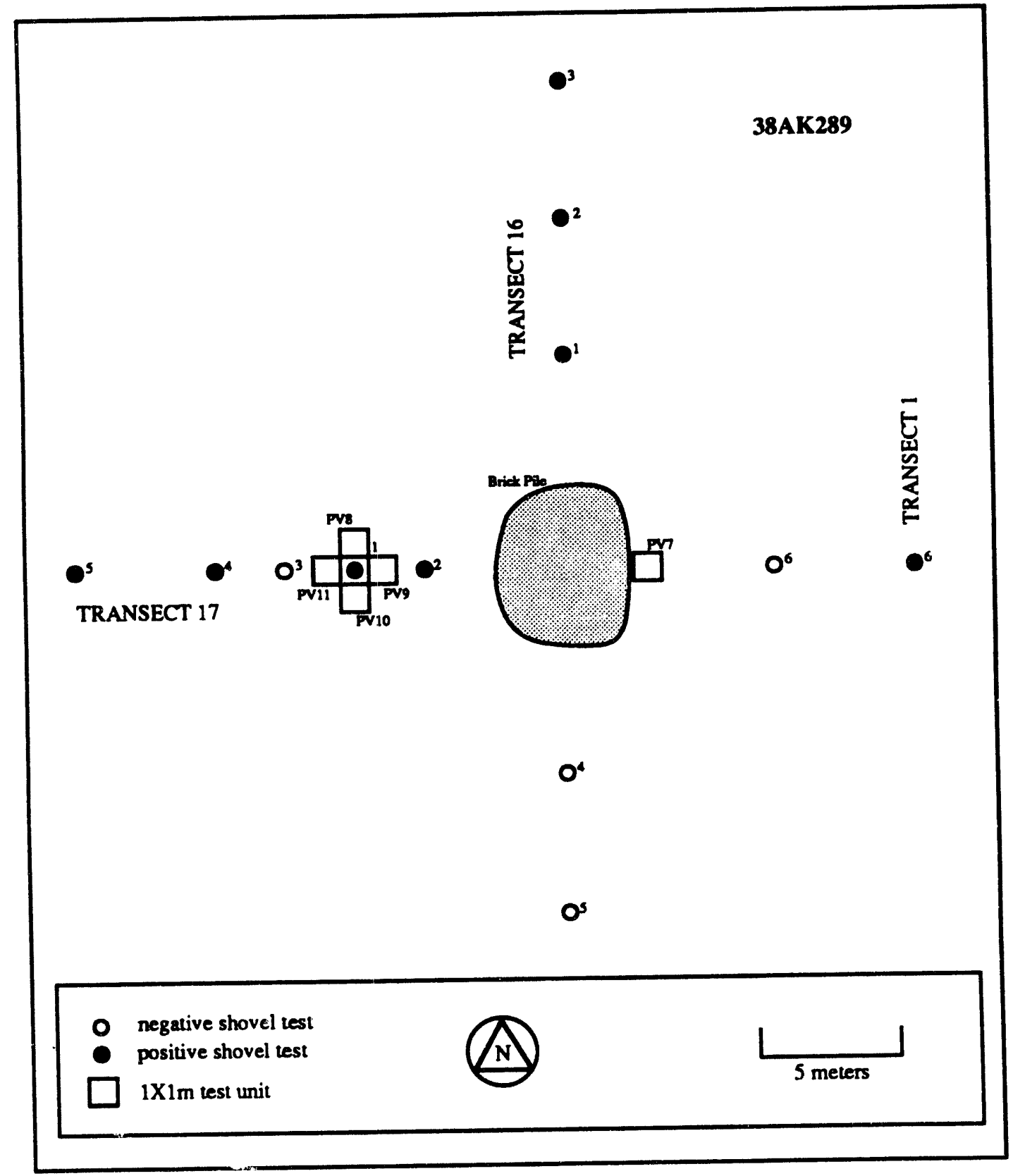

Figure 29. Southeast portion of 38AK289, showing locations of shovel tests and test units in vicinity of historic period rock pile.

testing of the project area. Thirteen shovel tests spaced 10 to $30 \mathrm{~m}$ apart were dug along Transect 23 (Figure 30). Based on the distribution of surface and subsurface historic artifacts, this component has a spatial dimension of $25 \times 70 \mathrm{~m}$. This occupation actually may have a wider extent, as several historic artifacts were recovered from shovel tests on the ridge slope. The presence of materials on the ridge slope, however, is most likely the result of erosion from the ridge top. 


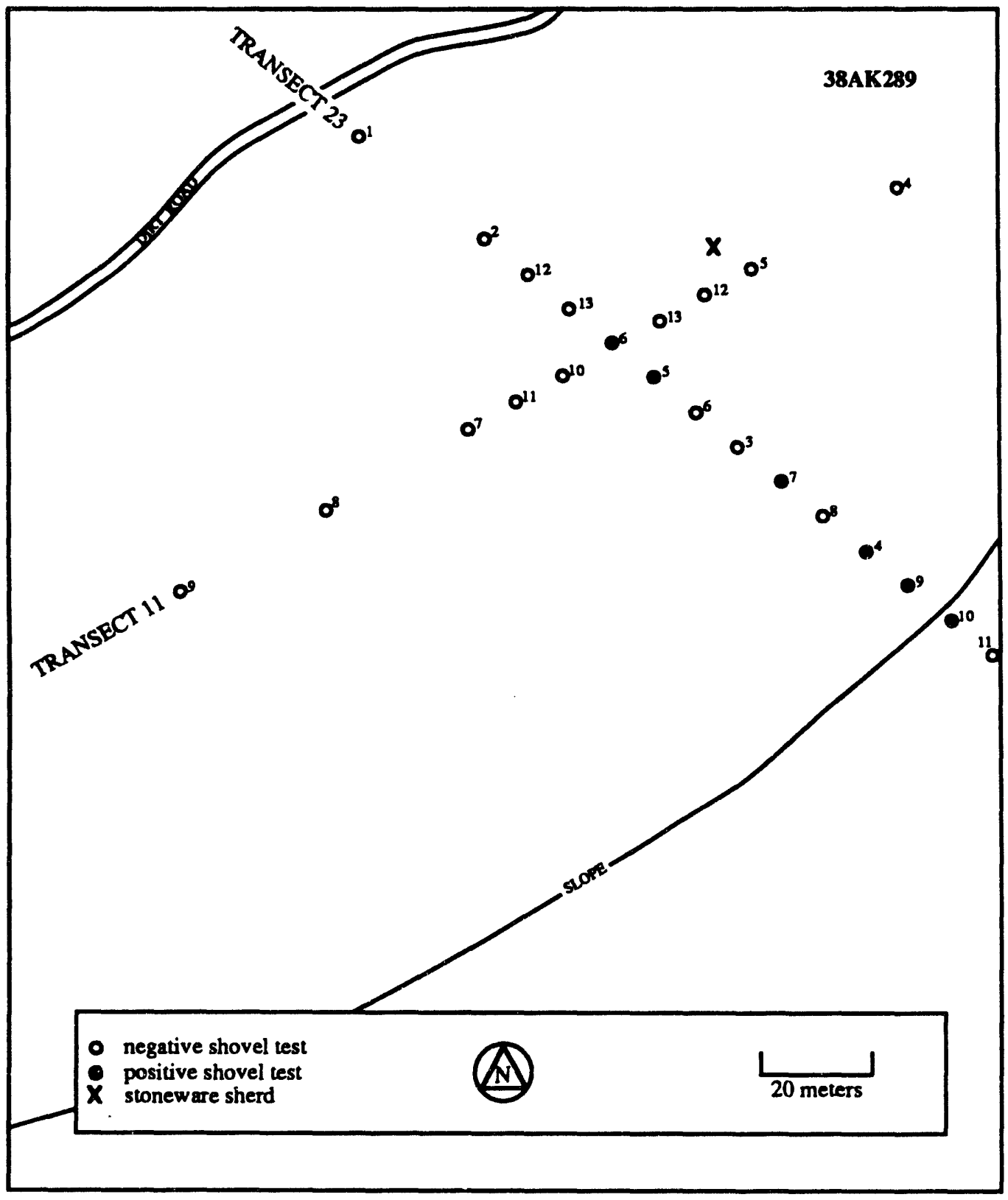

Figure 30. Westen margin of 38AK289, showing locations of shovel tests excavated to delineate early historic occupation.

Finally, close interval shovel testing was conducted at one other location within the boundaries of 38AK289. As noted in Chapter 3, the previously recorded historic site 38AK284, found during the 1982 survey, could not be relocated during the initial testing of the SREL project area because of inaccurate locational recording on the topographic base map. Information provided in the site file indicated that 38AK284 was situated along the south side of SRS Road 219 in the vicinity of this project's Transects 5 and 6 (Figure 31). An investigation of the area consisted of six shovel tests excavated in a 


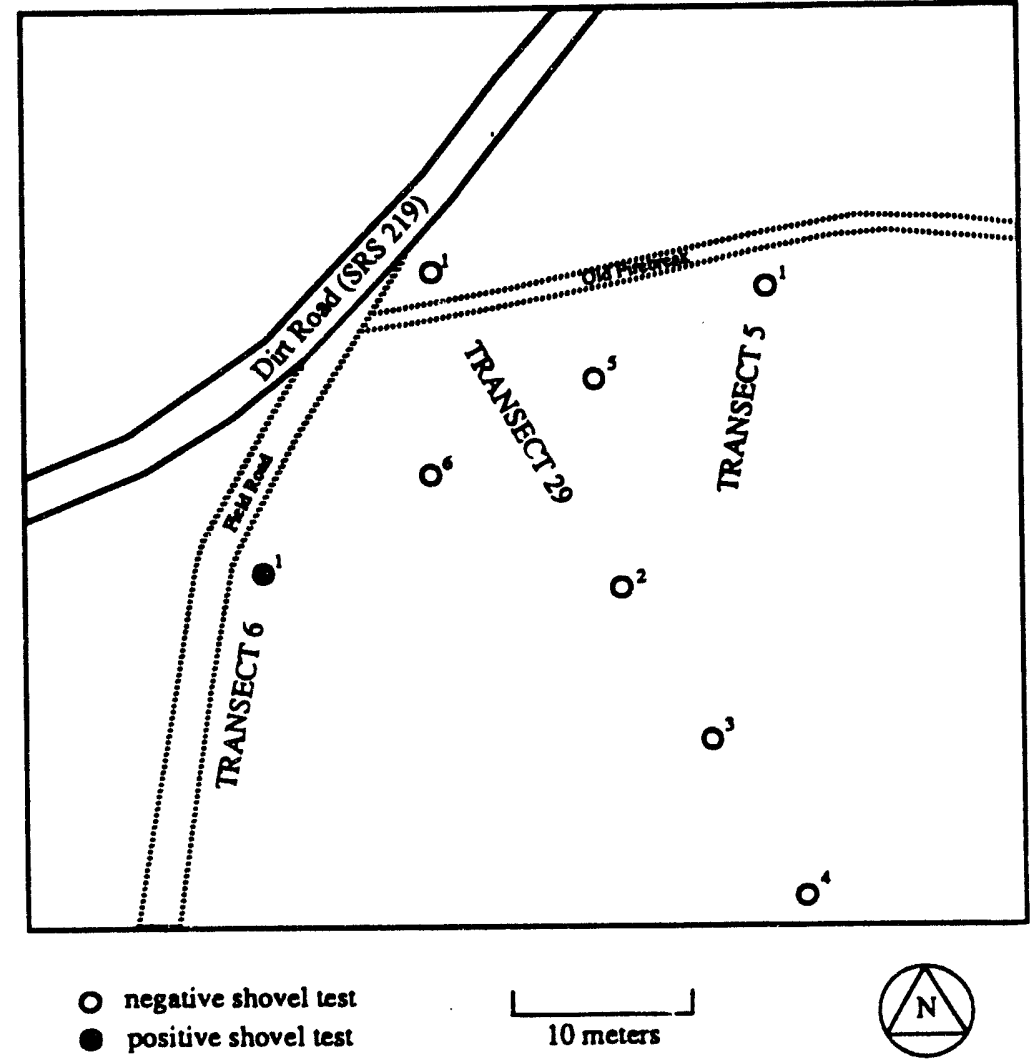

Figure 31. Shovel tests excavated in the north-central portion of 38AK289.

cruciform pattern along Transect 29. All of these tests were negative. As a result, the exact location of site 38AK284 remains unknown.

In summary, 38AK289 is situated on a ridge top, ridge side slope, and terrace edge landform along the western margin of Upper Three Runs Creek. Initially recorded in 1982 during a stratified random sample survey of the Upper Three Runs watershed, 38AK289 was characterized as a single component historic site measuring $100 \times 100 \mathrm{~m}$. Intensive subsurface survey for the proposed SREL Conference Center demonstrated that 38AK289 was actually multicomponent with archaeological remains scattered over an area measuring $400 \times 550 \mathrm{~m}$. Several test units were excavated at different locations to evaluate the integrity and density of cultural deposits across the site. These tests revealed that intact buried materials were fairly well stratified to a depth of $80 \mathrm{~cm}$ BS. Close interval shovel tests were employed to delineate the dimensions of two horizontally discrete historic occupations located on the eastem and westem extremes of the site. The work conducted at 38AK289 revealed evidence for human occupation from early prehistoric to modern times.

\section{Artifact Analysis: $38 A K 289$}

Previous investigations at 38AK289, described above, resulted in two artifact collections, which were assigned the surface proveniences $1 \emptyset$ and $2 \varnothing$. These assemblages contain a total of 18 artifacts and two cobble fragments. Specifically, Provenience $1 \varnothing$, consisting of artifacts confiscated from pothunters, includes one Savannah River Stemmed Biface, one other biface, four historic soda bottles, and one 
cobble fragment. Provenience $2 \varnothing$, all surface collected from pothole backdirt, contains eight flakes, one utilized flake, and two fine cordmarked sherds. The prehistoric lithic and ceramic diagnostic artifacts in these collections are related to Late Archaic and probably Late Woodland period site use.

During the recent investigations of 38AK289, a total of 1589 artifacts was recovered from surface and subsurface contexts. Discussions of these artifacts by class and type are presented in the following subsections.

\section{Prehistoric Artifacts}

The prehistoric assemblage contains a total of 1521 ceramic and lithic artifacts. An additional 1663 miscellaneous pieces of unmodified and cracked rock, bone fragments, and burned clay nodules were collected, but these cannot definitely be assigned to any specific component. Table 2 provides frequency summaries of prehistoric artifacts and miscellaneous items by gross category and type of provenience, and an assemblage inventory by provenience is given in Appendix B.

Ceramics. A total of 66 prehistoric sherds was recovered from all proveniences of 38AK289. A summary of sherds by type and provenience type is provided in Table 3, and an inventory by provenience is provided in Appendix D. All but one sherd from 38AK289 are sand- or coarse-sand tempered. The exception is a small fiber-tempered sherd exhibiting a smoothed, plain exterior surface and fiber casts on the interior (Figure 32i). Dominating the assemblage are $37(56 \%)$ eroded sherds and $20(30 \%)$ sand tempered plain sherds. The remaining sherds have surface decorations that can be assigned to general cultural-historical classes. These include linear checked stamped, simple stamped, cordmarked, reed punctate, and unidentified complicated stamped, all represented by one to three sherds.

Although sand tempered plain sherds generally are not good temporal markers, certain ceramic attributes such as paste and thickness can be indicative of chronological periods. Five of the plain sherds from 38AK289 were recovered in various shovel tests along the terrace edge. The remaining 15 plain sherds were excavated from test unit Proveniences 5 and 14 also on the terrace edge. The paste of these sherds is homogeneous with well sorted coarse sand or grit tempering (Figure 32d, e). The exterior and interior surfaces are well smoothed and sherd thickness averages about $9 \mathrm{~mm}$. Based on the coarse sand temper and rather thick vessel walls, these sherds are most likely Middle Woodland (Deptford) in origin. The fifteen plain sherds were recovered from Proveniences 5 and 14 between 10 and $35 \mathrm{~cm} \mathrm{BS}$ and, based on their similar characteristics and proximity, seem to be fragments of the same vessel.

The two simple stamped sherds were recovered in separate shovel tests on the terrace edge (Figure $32 \mathrm{f}, \mathrm{g}$ ). Their paste characteristics are very similar to the sand tempered plain sherds just described. One sherd exhibits "U"-shaped stamping and the other "V"-shaped. Both finishes are applied in a parallel fashion. The sample is admittedly small, but the coarse paste is generally typical of Middle Woodland sherds and therefore indicates a Deptford occupation. Also, supporting a Deptford occupation is the presence in the collection of a single, diagnostic linear check stamped sherd (Figure 32h), recovered from Provenience 14.

Three cordmarked sherds were recovered separately from two shovel tests near the south-central portion of the site and from Level A in Provenience 14 (Figure 32c). 
Table 2. Prehistoric Artifact Inventory by Provenience Type, 38AK289.

\begin{tabular}{|c|c|c|c|c|c|c|c|c|}
\hline Prov. Type & $\begin{array}{l}\text { Hafted } \\
\text { Bifeces }\end{array}$ & $\begin{array}{l}\text { Other } \\
\text { Bifeces }\end{array}$ & Unifeces & $\begin{array}{l}\text { Utilized } \\
\text { Flizes }\end{array}$ & Debithe & $\begin{array}{l}\text { Ground- } \\
\text { tone }\end{array}$ & Shends & TOTAL \\
\hline Shovel Teats & 4 & 8 & 3 & 3 & 486 & 1 & 21 & 526 \\
\hline Test Units & 7 & 11 & 4 & 0 & 928 & 0 & 45 & 995 \\
\hline TOTAL & 11 & 19 & 7 & 3 & 1414 & 1 & 66 & 1521 \\
\hline
\end{tabular}

\begin{tabular}{lcccc}
\hline & Misc. Cracted & & Burned & \\
Prov. Type & Rock & Bone & Clyy & TOTAL \\
\hline Shovel Tests & 8 & 4 & 0 & 12 \\
Test Units & 1572 & 31 & 48 & 1651 \\
\hline TOTAL & 1580 & 35 & 48 & 1663 \\
\hline
\end{tabular}

Table 3. Prehistoric Pottery Frequency by Type and Provenience Type, 38AK289.

\begin{tabular}{|c|c|c|c|}
\hline Type & $\begin{array}{l}\text { Shovel } \\
\text { Teats }\end{array}$ & $\begin{array}{l}\text { Test } \\
\text { Units }\end{array}$ & TOTAL \\
\hline Fiber Tempered Plain & 1 & & 1 \\
\hline Sand Tempered Plain & 5 & 15 & 20 \\
\hline $\begin{array}{l}\text { Linear Check Stamped } \\
\text { \$mm }\end{array}$ & & 1 & 1 \\
\hline $\begin{array}{l}\text { Simple Stumped } \\
\text { "U" Parallel > } 2 \mathrm{~mm} \\
\text { "V" Parallel < } 2 \mathrm{~mm}\end{array}$ & $\begin{array}{l}1 \\
1\end{array}$ & & $\begin{array}{l}1 \\
1\end{array}$ \\
\hline $\begin{array}{l}\text { Cordmariked } \\
\text { Crossed < } 1 \mathrm{~mm} \\
\text { Perallel } 1-2 \mathrm{~mm}\end{array}$ & 2 & 1 & $\begin{array}{l}1 \\
2\end{array}$ \\
\hline Eroded & 3 & 3 & 6 \\
\hline $\begin{array}{l}\text { Sherds }<1 / 2^{n} \text { in size } \\
\text { Reed Punctate } \\
\text { Unidentified Comp. Stamped } \\
\text { Eroded }\end{array}$ & 7 & $\begin{array}{r}1 \\
1 \\
24\end{array}$ & $\begin{array}{r}1 \\
1 \\
31\end{array}$ \\
\hline TOTAL & 20 & 46 & 66 \\
\hline
\end{tabular}

The cord impressions on these sherds are not very wide, measuring between 1-2 mm or less, and are oriented in both crossed and parallel directions. The paste is sand tempered and sherd thickness averages $6.5 \mathrm{~mm}$. Cordmarking is present in both the Deptford and Late Woodland periods, but increased in popularity during the latter. Generally, cord impressions became finer through time along with a decrease in vessel wall thickness. Based on the ceramic and decorative attributes of the cordmarked sherds at 38AK289, they probably represent a Late Woodland occupation.

Two small (less than 0.5 in) decorated sherds, recovered in a shovel test and test unit excavation conducted in the vicinity of the historic rock pile, may be indicative of Early Mississippian habitation at 38AK289. One sherd exhibited a double row of reed punctations directly below the rim (Figure 32a) and the other an indeterminate 


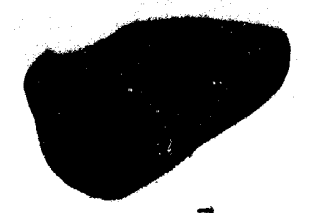

a

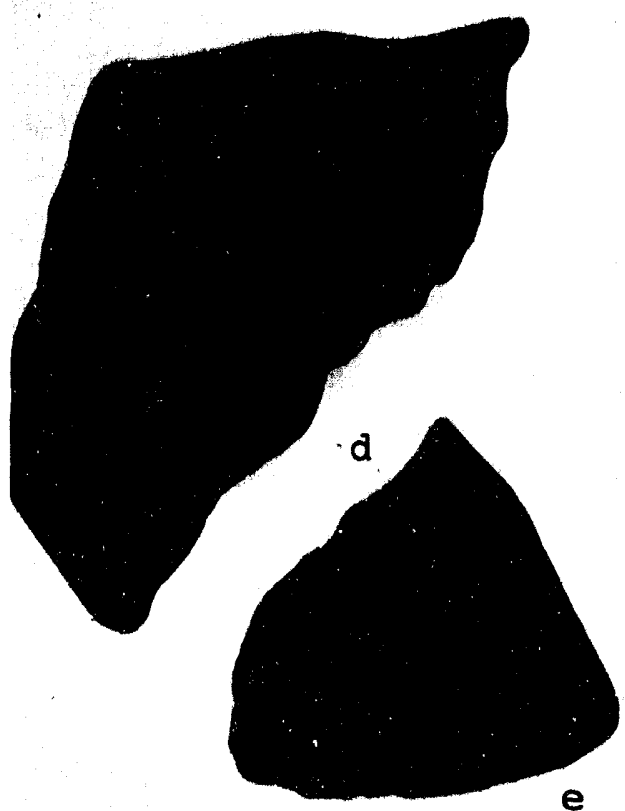

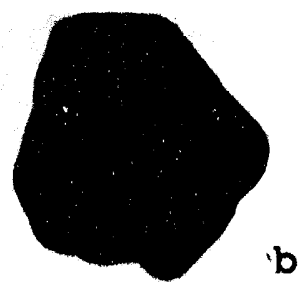

b
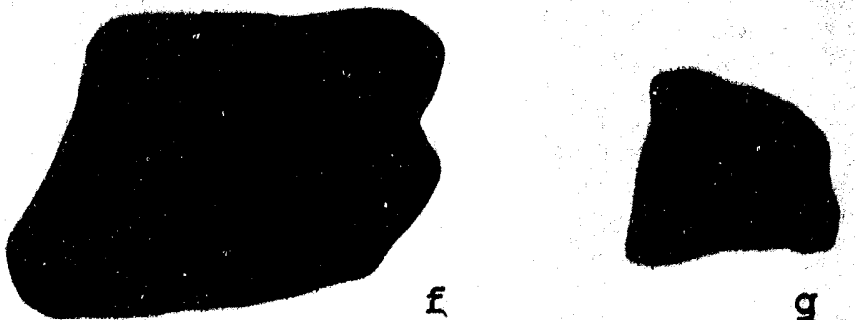

⿷

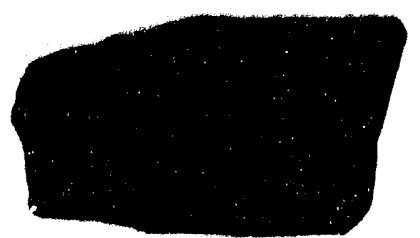

$\mathrm{h}$

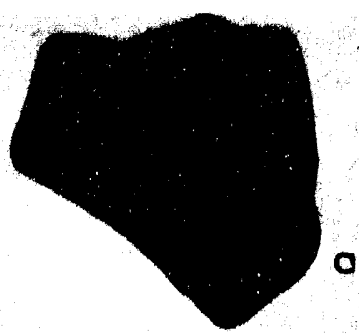

Figure 32. Prehistoric ceramic sherds from sites in the project area.

a. Mississippian Reed Punctate? 38AK289-13-1x-34; b. Late Woodland/Early Mississippian Rectilinear Complicated Stamped 38AK288-11-3x-31; c. Late Woodland Cordmarked 38AK289-14-A-27; d. Middle Woodland Deptford Plain 38AK289-14-E-32; e. Middle Woodland Deptford Plain 38AK289-5-D-32; f. Middle Woodland Deptford Simple Stamped ("U"-Shaped) 38AK289-13-6-7x-27; Middle Woodland Deptford Simple Stamped ("V"-Shaped) 38AK289-13-19-1x-23; h. Middle Woodland Deptford Linear Check Stamped 38AK289-14-A-26; i. Late Archaic Stallings Fiber-Tempered Plain 38AK289-13-1x-19.

complicated stamped design. Reed punctations as a decorative technique are common on Early to Middle Mississippian period vessels along the South Carolina/Georgia Coast and in the Savannah River Valley (Caldwell et al. 1941:42; Anderson, et al. 1986:41; Williams and Shapiro 1990:55, 71). However, reed punctations also occur on Late Archaic Thom's Creek and Early Woodland Refuge phase sherds in the middle Savannah River Valley (Sassaman et al. 1990:185-191; Sassaman 1992a:118-122). The size of the reed punctated sherd makes it difficult to assign a temporal designation, but the depth of recovery at about $15 \mathrm{~cm} \mathrm{BS}$ and its association in the topsoil with a sherd bearing complicated stamping reasonably argues for Mississippian origins.

Bifaces. A total of 30 bifaces was recovered at 38AK289. Eleven of the specimens are hafted bifaces, eighteen are other bifaces, and one is an amorphous core. A summary of bifaces by type and provenience type is provided in Table 4. Data on these artifacts are provided in Appendices $\mathrm{E}$ and $\mathrm{F}$. These bifaces were identified as to type in accordance with published descriptions by Coe (1964), Michie (1966), Oliver (1981), Sassaman et al. (1990). 
Table 4. Prehistoric Biface Frequency by Type and Provenience Type, 38AK289.

\begin{tabular}{|c|c|c|c|}
\hline Type & $\begin{array}{c}\text { Shovel } \\
\text { Tests }\end{array}$ & $\begin{array}{l}\text { Test } \\
\text { Units }\end{array}$ & TOTAL \\
\hline \multicolumn{4}{|l|}{ Hafted Bifaces } \\
\hline Small Woodland Stemmed & 2 & & 2 \\
\hline Badin & & 1 & 1 \\
\hline Small Savannah River Stemmed & & 2 & 2 \\
\hline MALA & 1 & & 1 \\
\hline Morrow Mountain & & 2 & 2 \\
\hline Kirk Corner Notched & 1 & & 1 \\
\hline Taylor & & 1 & 1 \\
\hline Indeterminate Basal Fragment & & 1 & 1 \\
\hline Subtotal & 4 & 7 & 11 \\
\hline \multicolumn{4}{|l|}{ Other Bifaces } \\
\hline Preform & & 3 & 3 \\
\hline Preform Pragment & & 1 & 1 \\
\hline Midsection Fragment & 1 & & 1 \\
\hline Edge Pragment & 3 & 4 & 7 \\
\hline Tip Fragment & 3 & 1 & 4 \\
\hline Indeterminate Fragment & 1 & 1 & 2 \\
\hline Amorphous core & & 1 & $\overline{1}$ \\
\hline Subtotal & 8 & 11 & 19 \\
\hline TOTAL & 12 & 18 & 30 \\
\hline
\end{tabular}

Three distinct morphological types are present in the hafted biface assemblage: notched, stemmed, and triangular. Stemmed bifaces $(n=8)$ form the majority of the collection. One basal corner fragment of a stemmed biface is present, but is unidentifiable as to type. Of the remaining identifiable stemmed bifaces, all but three of the bifaces are broken, with the majority exhibiting lateral snaps at the haft or along the blade. With regard to raw material, only one of the hafted bifaces is made from material other than chert. This biface, a Kirk Corner Notched (Figure 33c), is manufactured from orthoquartzite, presumably procured from the bluff outcrops of Upper Three Runs Creek.

A notched biface technology is represented in the assemblage by two specimens (Figure 33a, c). The haft elements of a Taylor Side Notched and a Kirk Corner Notched were recovered from proveniences near the Conference Center footprint. They were probably discarded as a result of retooling activities during short term visits to 38AK289. These biface types are indicative of Early Archaic period occupations at the site.

A Middle Archaic period occupation is represented by two Morrow Mountain Stemmed bifaces recovered from test unit excavations on the terrace edge (Figure 33e, f). One of these is a basal element. The other is whole, but small in size due to extensive resharpening. It also exhibited complete thermal alteration most likely attributed to intentional burning.

Based on technological as well as morphological characteristics, one specimen in the assemblage is identified as a MALA (Figure 33g; Sassaman 1985). A possible impact fracture to the midsection suggests a projectile function for the tool. The MALA biface, as the acronym indicates, is a marker for Middle Archaic-Late Archaic transition (60005000 BP) occupation at 38AK289. 
Figure 33 (facing page). Diagnostic hafted bifaces and unifaces from sites in the project area.

a. Early Archaic Taylor Side-Notched Stemmed Biface 38AK289-12-I-8; b. Early Archaic Kirk CornerNotched Stemmed Biface 38AK289-25-2x-8; c. Early Archaic Taylor Side-Notched Stemmed Biface 38AK287-4-F-9; d. Early Archaic Unifacial Hafted End Scraper 38AK289-5-H-4; e. Middle Archaic Morrow Mountain Stemmed Biface 38AK289-14-E-15; f. Middle Archaic Morrow Mountain Stemmed Biface 38AK289-14-I-11; g. Middle Archaic-Late Archaic (MALA) Stemmed Biface 38AK289-13-2-2x17; h. Late Archaic/Early Woodland Small Savannah River Stemmed Biface 38AK289-5-F-18; i. Late Archaic/Early Woodland Small Savannah River Stemmed Biface 38AK289-14-H-17; j. Early Woodland Stemmed Biface 38AK289-13-17-2x-17; k. Early Woodland Stemmed Biface 38AK287-5-B; 1. Early Woodland Stemmed Biface 38AK289-13-21-3x-17; m. Middle Woodland Badin Triangular 38AK289-5-C17; n. Late Woodland Triangular 38AK287-8-9x-16. 


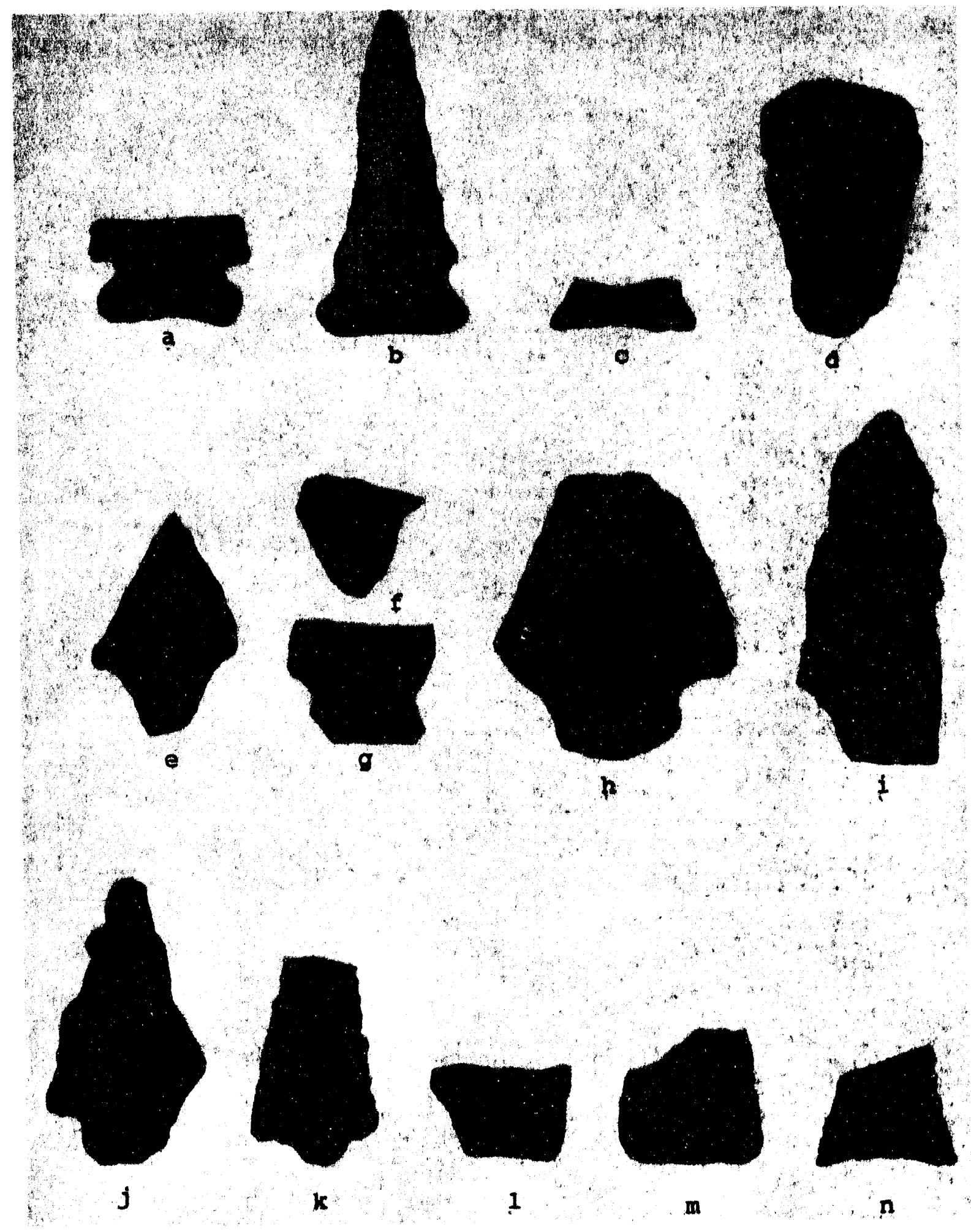


Present in the collection are two Small Savannah River Stemmed bifaces that probably relate to a Late Archaic-Early Woodland transition occupation of the site (Figure $33 \mathrm{~h}, \mathrm{i}$ ). Although this type may date as early as 5000 B.P., its diminutive stem and blade morphology are more common to ceramic Late Archaic-Early Woodland lithic technology. Like most of the assemblage specimens, these bifaces are highly resharpened and were probably discarded for lack of serviceable edge.

The assemblage contains two specimens recovered from shovel tests located on the terrace edge that probably relate to Early Woodland site use. One is a square stemmed base fragment and the other is a stemmed point with multiple potlids resulting from direct exposure to heat (Figure $33 \mathrm{j}, 1$ ). Early Woodland stemmed bifaces recovered from sites in the middle Savannah River Valley can usually be identified on technological grounds (Sassaman 1992a:165). In contrast to the formalized bifaces of the Archaic Period, Early Woodland bifaces lack regularity in design and execution. Most exhibit deep and irregular flake scarring on one or both faces as a result of hard hammer techniques with only fine bifacial work used to shape the edges. The Early Woodland bifaces in this assemblage were identified on the basis of these characteristics.

The final hafted biface in the collection is identified as a Badin (Figure 33m). It is triangular in shape with a thinned, straight base and large, broad, flaking scars on both faces. This biface relates to Middle Woodland period site use.

In the other biface assemblage are three preforms, one preform fragment, one midsection fragment, seven small edge fragments, four biface tips, and two indeterminate fragments, all manufactured from Coastal Plain chert. Also present in the collection is a patinated, exhausted amorphous chert core that attests to on-site tonl production. Recovered from Level K (60-65 cm BS) of Provenience 14, it is most likely associated with the buried Early Archaic component on the terrace edge. Other indicators of on-site tool manufacture are the four preforms, which reflect core/blank reduction in the manufacture of stemmed bifaces.

Little can be said about the miscellaneous biface fragments. Most of the small edge fragments, midsection fragments, biface tips, and indeterminate fragments are probably derived from the use and maintenance of hafted bifaces. Based on the small quantity of preforms in comparison to the frequency of biface fragments, the assemblage does not reflect a great deal of tool manufacture on the site. What little tool manufacture that did occur was probably limited to secondary and late-stage reduction of transported blanks and preforms.

In sum, the assemblage from 38AK289 includes examples of discarded tools and extensive biface maintenance. Bases outnumber tips almost three to one, suggesting that tool replacement was more common than tool use (i.e., projectile use damage) at the site. The large quantity of exhausted bifaces and basal portions is indicative of retooling at short term camps for the purpose of resource procurement. This is in line with current models regarding seasonal site use of upland habitats in the Aiken Plateau, especially during the Archaic period. The biface collection also reflects a conservative use of lithic tools during the early periods of site occupation. This is most likely attributed to the distance from the major source of chert located at the Allendale quarries (Goodyear and Charles 1984). As chronological markers, the biface assemblage indicates occupations spanning the Early Archaic through the Middle Woodland periods.

Unifaces and Utilized Flakes. Ten flakes in the lithic assemblage exhibit some trace of use-wear or unifacial technological modification of an edge. A summary of these tools by type and provenience type is provided in Table 5, while more detailed data are 
Table 5. Uniface and Utilized Flake Frequency by Type and Provenience Type, 38 AK289.

\begin{tabular}{lccc}
\hline Type & $\begin{array}{l}\text { Shovel } \\
\text { Tests }\end{array}$ & $\begin{array}{l}\text { Test } \\
\text { Units }\end{array}$ & TOTAL \\
\hline Uniface & 3 & 4 & 7 \\
Utilized Flake & 3 & & 3 \\
\hline TOTAL & 3 & 4 & 10 \\
\hline
\end{tabular}

provided in Appendix G. As is reflected in Table 5, unifaces dominate the sample $(n=7)$, where as only three specimens of utilized flakes are noted. Five of the unifaces are expedient tools manufactured from fragments of broken flakes. One informal uniface is identified as a graver. One patinated formal uniface is present in the collection and is identified as a hafted end scraper (Figure 32d). This diagnostic tool was recovered in Provenience 5 at about $75 \mathrm{~cm} \mathrm{BS}$ and is related to Early Archaic site use.

Utilized flakes are probably produced from the reduction of amorphous cores. Subsequent use as expedient tools resulted in macroscopic traces of use wear on one or more edges. A total of five use-edges were observed among the three flakes. The shapes of use-edges include one convex, two irregular, and two concave edges.

Groundstone. One fragment of greenstone, recovered from a shovel test, is present in the collection. It exhibits minute parallel and crossed striations on the polished face.

Debitage. Debitage comprises the most abundant artifact class in the lithic assemblage. A total of 1,414 pieces of debitage was recovered from subsurface contexts. Data on flake size, condition and raw material are provided in Appendix $H$. The sample of debitage from 38AK 289 consists of small biface thinning flakes, the majority of which $(n=1,222 ; 86 \%)$ are broken. Nearly all $(n=1,346 ; 95 \%)$ of the 1,414 flakes in the collection are Coastal Plain chert; $40(3 \%)$ are quartz, and $28(2 \%)$ are orthoquartzite. Sources for both the chert, quartz, and orthoquartzite flakes may be local as outcrops of these materials occur in the nearby bluffs of Upper Three Runs Creek. Irrespective of the local availability of lithic material, the chert debitage from 38AK289 is diverse in its color, texture, and structure, and most likely represents a combination of local and extralocal Coastal Plain sources, including the Allendale chert quarries (Goodyear and Charles 1984).

The majority of whole flakes in the collection are small. Nearly 83 percent of the flakes have planview areas less than $400 \mathrm{~mm}^{2}$ (i.e., size class 3 or smaller). About eight percent $(n=11)$ of the whole flakes have traces of cortex on dorsal surfaces, but these are generally no larger than noncortical flakes. Overall, the relatively small size of flakes, cortical and noncortical alike, is evidence that lithic core reduction, if it occurred at all, was probably limited to secondary and later stages; primary core reduction, if it occurred at all, was probably limited to small cortical nodules.

Prehistoric Artifact Analysis Summary. The artifact collection from 38AK289 represents a relatively small, but diverse sample of lithic and ceramic artifacts recovered from shovel tests and test unit excavations. At least six prehistoric components are reflected in the incidence of diagnostic artifacts. The ceramic data document occupation during the Late Archaic, Middle and Late Woodland, and possibly Early Mississippian 
during the Late Archaic, Middle and Late Woodland, and possibly Early Mississippian periods. The lithic data indicate three distinct hafted biface traditions: notched bifaces that correspond with Early Archaic occupations; stemmed bifaces that relate to Middle and Late Archaic, and Early Woodland site use; and a triangular that indicates a Middle Woodland occupation.

\section{Historic Artifacts}

The historic assemblage, as summarized in Table 6 , contains 68 artifacts consisting of architecture-related materials, ceramics, kitchen-related ware, macrobotanical remains, and miscellaneous items. An assemblage inventory by provenience is given in Appendix $I$.

Architecture. Architecture-related artifacts are the largest analytical category recovered from 38AK289. Of the 39 artifacts in this class, twelve are brick fragments (all appear to be soft-mud), and eighteen are mortar nodules. None exhibit perforations. Although a perforation machine was used as early as 1845 on stiff-mud bricks manufactured in England (Gurcke 1987:112), they have not been found in nineteenth century contexts on the SRS; indeed, they are most often associated with buildings constructed in the 1930s and later. The nine remaining specimens are nails. Two of these are wrought head/wrought shank nails (to ca 1790), one is a wrought head/cut shank nail (ca. 1790-1815), and five are cut head/cut shank nails with no evident waisting (ca. 18201900). Of these, two were snapped as a result of clenching. This may indicate that the metal fibers run crosswise to the nail's length, which is characteristic of a pre-1830 manufacture date. One nail was a wire specimen (not earlier than 1850, probably ca. 1890-1951).

Ceramics. Of the 18 ceramic sherds recovered from 38AK289, all but seven are refined earthenware. Eight of these are undecorated creamware, including one basal sherd, one plate rim, and one marley. Three are pearlware sherds. Of the pearlware, one specimen is a dark blue transfer-printed marley (popular ca. 1820-ca. 1830; Henry Miller, personal communication), one is undecorated, and one is bowl rim with a hand painted dark blue fineline and dot motif. A green banded flatware rim of ironstone/whiteware (commonly referred to as "hotel ware") completes the refined earthenware inventory. One body sherd of colonoware comprises the coarse earthenware in the assemblage. Five pieces of alkaline-glazed stoneware were recovered. Of these, two are glazed on both the interior and exterior, two are glazed on the exterior only, and one is glazed on the exterior in alkaline glaze and on the interior with a natural clay slip. Alkaline, or wood-ash, glazes, were first popular throughout the Southeast from the early nineteenth century into the twentieth century (Sweezy 1984: 22-23; Holcomb and Holcomb 1989:11-131). Temporally, alkaline glazes precede Albany or natural slips, which become popular with the coming of the railroad trade in the decades following the Civil War (Sweezy 1984:23).

Table 6. Frequencies of Historic Artifacts by Analytical Class, 38AK289.

\begin{tabular}{lcc}
\hline Class & $\begin{array}{c}\text { Absolute } \\
\text { Prequency }\end{array}$ & $\begin{array}{c}\text { Relative } \\
\text { Prequency }\end{array}$ \\
\hline Architectural & 39 & 57.4 \\
Ceramics & 18 & 26.5 \\
Kitchen & 3 & 4.4 \\
Macrobotanical & 1 & 1.5 \\
Activities & 1 & 1.5 \\
Miscellaneous & 6 & 8.8 \\
\hline TOTAL & 68 & 100.0 \\
\hline
\end{tabular}


The 18 sherds described above represent at least nine different vessels. These include one colonoware vessel, two creamware vessels, one ironstone/whiteware vessel, one pearlware vessel, and two alkaline glazed stoneware vessels, all of unknown morphology, one pearlware bowl, one and one alkaline glazed jar.

Kitchen. Only three diagnostic glass shards were recovered from 38AK289. Of these, two are dark gre in (or "black") bottle glass shards, while one is a clear bottle or jar glass shard. 38 AK289.

Macrobotanical. One partially-carbonized peach pit was recovered from

Miscellaneous. Miscellaneous artifacts include one shard of flat glass, 2 shards of unidentified glass, three pieces of unidentified thin metal scrap, and one unidentified swivel part.

\section{AK287: Results of Field Investigations}

Site 38AK287 was initially located in November of 1982 during a clearcut survey. The site is located on a terrace edge overlooking the floodplain of Upper Three Runs Creek (Figure 7) and is characterized as multicomponent with occupations spanning the Early Archaic through the early nineteenth century. Based on a surface scatter of prehistoric and historic artifacts, site size was originally estimated at $35 \times 70 \mathrm{~m}$. Two historic features consisting of a brick pile and a hand hewn beam were present at the site. A second surface collection was made during a revisit in August of 1983.

Site 38AK287 was relocated in 1992 during survey of the original project design (Figure 34; Table 7). Transect shovel tests along the initially proposed easement on the terrace edge intercepted the eastern margin of the site (Provenience 9). Subsequent transect shovel tests along the relocated easement intercepted the western margin of the site (Provenience 7). Two lines of shovel tests (Proveniences 3 and 8) verified the presence of buried deposits between Proveniences 7 and 9. Altogether, 39 shovel tests were excavated in an effort to determine the extent of buried remains at 38AK287. Based on the occurrence of 22 positive tests, new site boundaries measuring $120 \times 225 \mathrm{~m}$ were established.

To assess the subsurface integrity, a $1 \times 2 \mathrm{~m}$ test unit designated Provenience 4 was placed $50 \mathrm{~cm}$ to the south of STP 1 on Provenience 3. The test unit was oriented in cardinal directions and excavated in arbitrary $10 \mathrm{~cm}$ levels to a depth of $100 \mathrm{~cm}$ BS. The soil profile to a depth of one meter contains three recognizable zones (Figure 34). From the surface to a depth of about $20 \mathrm{~cm}$ BS is a dark brown (10YR4/3) silty-fine sandy loam topsoil. Contact with the underlying zone is sharp. This underlying zone, designated Feature 1 and described below, consists of mottled yellowish brown (10YR5/4; 10YR5/8) and very pale brown (10YR7/4) sandy loam that extends about $10 \mathrm{~cm}$ below the topsoil. Below Feature 1 to $100 \mathrm{~cm}$ BS is a homogeneous yellowish brown (10YR5/8) sandy loam. Cultural debris was recovered from Levels A-H $(0-80 \mathrm{~cm}$ BS) with historic materials confined to the topsoil layer $(0-20 \mathrm{~cm} \mathrm{BS})$ and prehistoric artifacts in Levels BH (10-80 cm BS).

In the floor of Proveniece 4 at $20 \mathrm{~cm} \mathrm{BS,} \mathrm{a} \mathrm{soil} \mathrm{stain,} \mathrm{designated} \mathrm{Feature} \mathrm{1,} \mathrm{was}$ encountered extending $20-25 \mathrm{~cm}$ from the north profile (Figure 35). This feature consisted of very loosely compacted mottled yellowish brown (10YR5/4; 10YR5/8) and very pale brown (10YR7/4) sandy loam in a surrounding matrix of homogeneous yellowish brown (10YR5/8) sandy loam. Feature 1 measured $1.90 \mathrm{~m}$ in length and 


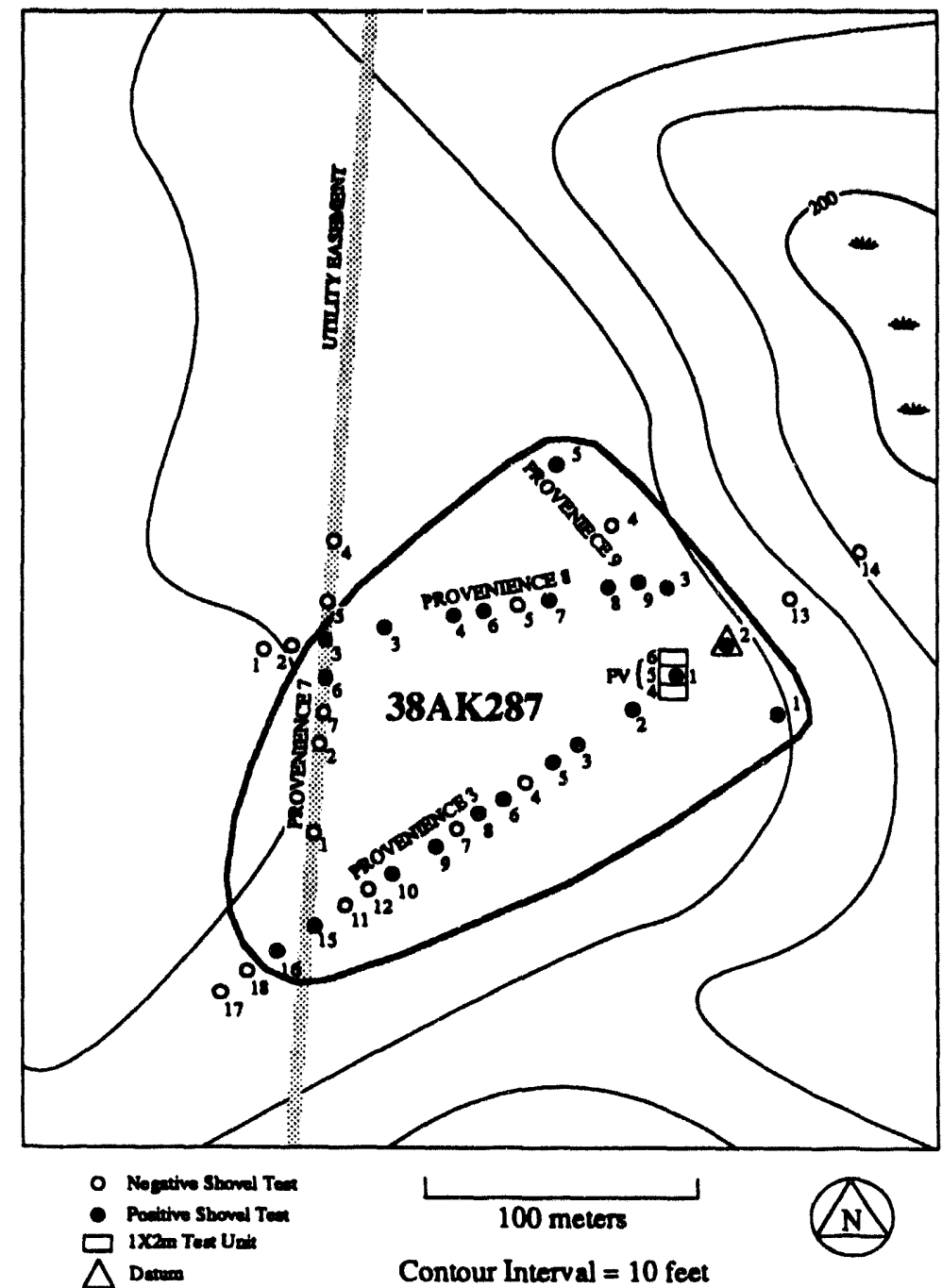

Figure 34. Site map for 38AK287.

Table 7. Specifications for Site 38AK287.

Cultural Components

Descriptive Site Type

Site Dimensions

Depth of Cultural Material

Landform Location

Elevation AMSL

Blevation Above Nearest Rank 3 Stream

Distance to Water:

Soil Type

Soil Classification

Soil Description

Ground Cover
Unt prehistoric; Twentiath century

Lithic/ceramic scatter; Home place

$120 \times 225 \mathrm{~m}$

$0-80 \mathrm{~cm} B S$

Terrace edge

230 f

$40 \mathrm{n}$

$475 \mathrm{~m}$

Blanton

Sand

Excessively drained

Heavy 

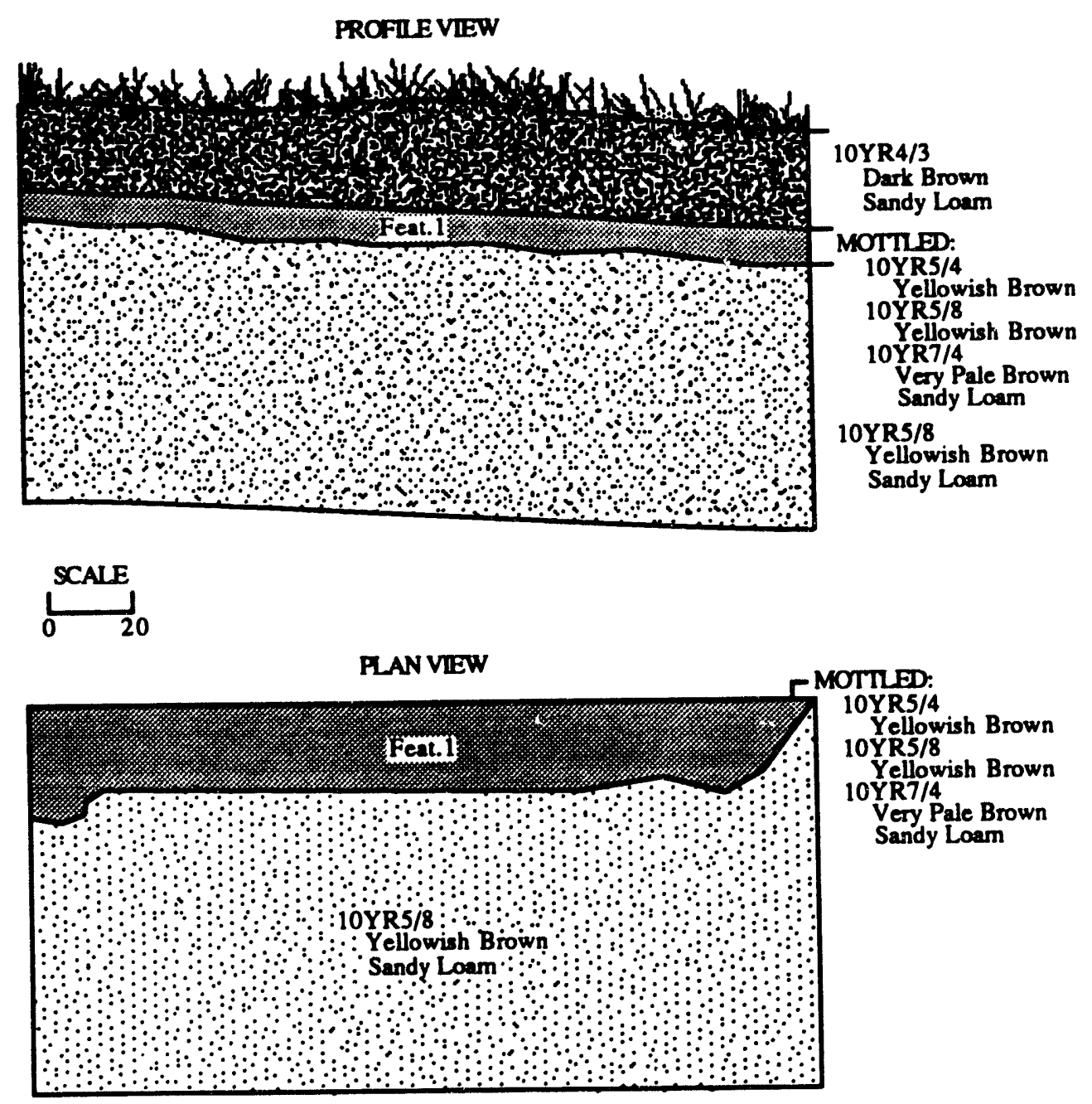

Figure 35. North profile drawing (top) and planview at $20 \mathrm{~cm}$ BS (bottom) of Provenience 4, 38AK287.

paralleled the north profile. In cross-section, Feature 1 was $10 \mathrm{~cm}$ in depth and terminated at $30 \mathrm{~cm}$ BS. The feature fill was screened separately from the surrounding soil, but was devoid of artifacts.

To further investigate Feature 1, two adjacent $1 \times 2 \mathrm{~m}$ test units (Proveniences 5 and 6) were excavated in arbitrary $10 \mathrm{~cm}$ levels to the top of Feature 1 at $20 \mathrm{~cm}$ BS. Even with this exposure, the entire floors of both units contained feature fill with no edges present. Feature 1, which is certainly modern in origin, is believed to be a buried roadbed. This interpretation is corroborated by documentary information from a 1921 topographic map (United States Army Corps of Engineers [USCOE] 1921) that shows an old dirt road crossing through the location of the site. The artifact bearing topsoil layer overlying Feature 1 is a result of erosional wash that occurred after the road fell into disuse. 
Artifact Analysis: 38AK287

Previous investigations at 38AK287, described above, resulted in two artifact collections, which were assigned the surface proveniences $1 \varnothing$ and $2 \varnothing$. These assemblages contain a total of 45 artifacts. Specifically, Provenience $1 \varnothing$ consists of 17 flakes, one unidentified hafted biface, one sand tempered plain sherd, three whiteware sherds, one glass shard, and three bone fragments. Provenience $2 \varnothing$ contains 14 flakes, one utilized flake, one other biface, three sand tempered plain sherds, one cordmarked sherd, and one shell edge pearlware sherd. The only identifiable prehistoric ceramic diagnostic artifact in either collection is the cordmarked sherd, and it is probably a product of Late Woodland period site use. The diagnostic historic artifacts indicate a mid-to-late nineteenth century occupation.

A total of 267 artifacts was recovered from subsurface contexts during the recent investigations of 38AK287. Descriptions of these artifacts by class and type are presented in the following subsections.

\section{Prehistoric Artifacts}

The prehistoric assemblage contains of total of 124 ceramic and lithic artifacts. An additional 864 pieces of unmodified and cracked rock along with seven fragments $(4.2 \mathrm{~g})$ of burned clay nodules were collected, but these cannot definitely be assigned to any specific component. Table 8 provides a summary of the frequency of prehistoric artifacts and cracked rock items by gross category and type of provenience and an assemblage inventory by provenience is given in Appendix $\mathbf{C}$.

Ceramics. A total of nine prehistoric sherds was recovered from 38AK287. A complete tabulation of sherds by provenience is provided in Appendix D. Six of the sherds are eroded and the remaining three are plain sand tempered. Two of the plain sherds were recovered from test unit Proveniences 4 and 6 in the topsoil layer $(0-20 \mathrm{~cm}$ BS) and the third plain sherd was from a shovel test. Generally, plain sand tempered sherds are not time sensitive, but the shallow depth of the plain sherds in Proveniences 4 and 6 may be indicative of a Late Woodland period date. Even this assumption, however, is somewhat dubious because of the disturbed context of the topsoil layer over the historic roadbed (Feature 1) described above.

Lithics. The lithic assemblage consists of three hafted bifaces, two other bifaces, one uniface, and one utilized flake. Data on these artifacts are provided in Appendices E-G. Three distinct morphological types are observed in the hafted biface collection: notched, stemmed and triangular. A quartz Taylor Side Notched biface (Figure 33b), recovered in Level F (50-60 cm BS) of Provenience 4, indicates an Early Archaic period occupation of the site. A small stemmed chert biface (Figure 33k) recovered from Level B (10-20 cm BS) probably relates to Early Woodland site use. The final hafted biface is a small chert

Table 8. Prehistoric Artifact Inventory by Provenience Type, 38AK287.

\begin{tabular}{lcccccccc}
\hline Prov. & $\begin{array}{c}\text { Hafted } \\
\text { Bifaces }\end{array}$ & $\begin{array}{c}\text { Other } \\
\text { Bifaces }\end{array}$ & $\begin{array}{c}\text { Uni- } \\
\text { faces }\end{array}$ & $\begin{array}{c}\text { Utilized } \\
\text { Flakes }\end{array}$ & Debitage & $\begin{array}{c}\text { Misc. Cracked } \\
\text { Rock }\end{array}$ & Sherds & TOTAL \\
\hline Shovel Tests & 1 & 1 & 1 & 1 & 49 & & 1 & 54 \\
Test Units & 2 & 1 & & & 59 & 864 & 8 & 934 \\
\hline Total & 3 & 2 & 1 & 1 & 108 & 864 & 9 & 988 \\
\hline
\end{tabular}


triangular (Figure 33n) from a shovel test that most likely represents a Late Woodland occupation. The other biface category includes the base of metavolcanic preform and an indeterminate fragment of Coastal Plain chert.

Two flakes in the assemblage exhibit some trace of use-wear or unifacial modification of an edge. Both the utilized flake and the uniface are expedient chert tools made on flakes probably produced from the reduction of amorphous cores. The utilized flake exhibited one convex use-edge. Two concave use-edges were observed on the unifacial tool.

Debitage comprises the most abundant artifact class in the lithic assemblage. A total of 108 pieces of debitage was recovered from subsurface contexts. Data on flake size, condition and raw material are provided in Appendix $H$. The sample of debitage from 38AK287 consists of small biface thinning flakes, the majority of which $(n=102$; $94 \%)$ are broken. Nearly all $(n=101 ; 93 \%)$ of the flakes in the collection are Coastal Plain chert with the remaining seven consisting of quartz. There are no cortical flakes in the assemblage and the six whole noncortical flakes are small (i.e., size classes 1 and 2). Overall, the absence of cortical flakes in the assemblage attests to the lack of primary core reduction at $38 \mathrm{AK} 287$ and the relatively small size of whole flakes is evidence that lithic reduction was generally limited to secondary and later stages.

\section{Historic Artifacts}

The historic artifact assemblage, as summarized in Table 9, contains 143 specimens including architecture-related materials, ceramics, kitchen-related ware, armsrelated materials, and miscellaneous items. An assemblage inventory by provenience is given in Appendix I.

Architecture. Architectural artifacis recovered from 38AK287 include 13 brick fragments. Although all are extremely fragmentary, they appear to be soft-mud bricks. Other architectural artifacts include three cut nails; one is a common head, one is a shaft, and the other specimen, which is complete, measures $6.5 \mathrm{~cm}(8 \mathrm{~d})$ long. This size nail is often found in small joists or sills (Jurney 1987:87). No wire nails were present in the assemblage, which may be indicative of a construction date prior to the late nineteenth century, when a wide variety of wire nails became available (Blackall 1876; Dreppard 1946; Nelson 1968; Noël Hume 1980:253-254).

Ceramics. The ceramic assemblage recovered from 38AK287 consists of ten sherds. Of these, all but one are undecorated ironstone/whiteware, a type of refined earthenware which became immensely popular after ca. 1820 to the present. These sherds include one cup base, two flatware rims, and one flatware base. The ceramic

Table 9. Frequencies of Historic Artifacts by Analytical Class, 38AK287.

\begin{tabular}{lcc}
\hline Class & $\begin{array}{c}\text { Absolute } \\
\text { Frequency }\end{array}$ & $\begin{array}{c}\text { Relative } \\
\text { Frequency }\end{array}$ \\
\hline Architectural & 16 & 11.2 \\
Ceramics & 10 & 7.0 \\
Kitchen & 10 & 7.0 \\
Arms-Related & 2 & 1.4 \\
Miscellaneous & 105 & 73.4 \\
\hline TOTAL & 143 & 100.0 \\
\hline
\end{tabular}


assemblage also includes one alkaline-glazed stoneware sherd which is glazed on both the interior and exterior.

Kitchen. Ten artifacts are related to kitchen functions; all are glass. Of the 114 shards of glass, only 10 bore diagnostic characteristics. These included two soda bottle fragments, one of which was a base, six canning jar fragments, and two pieces of manganese-decolored stemware (ca. 1875-ca. 1918; Jones and Sullivan 1985:14).

The ten sherds recovered from 38AK287 represent at least five vessels. These include two blue-tinted ironstone/whiteware plates, one white-tinted ironstone/whiteware vessel of unknown morphology, one burned ironstone/whiteware cup, and an alkaline drip-glazed vessel of unknown morphology. While blue-tinted whiteware was initially popular during the early nineteenth century and white-tinted wares became popular after approximately 1850 , blue-tinted wares continued to be shipped by the Staffordshire potters of England to rural markets in North America long after they were no longer used in urban centers (Jewitt 1972:504). Thus, while it is possible that the blue-tinted plates represent an occupation of the site prior to the mid-nineteenth century, the dearth of other temporally-diagnostic artifacts from this time period does not support that scenario.

Arms-Related Artifacts. Only two arms-related artifacts were recovered from this site. These are both shell casings. One is a .45 caliber specimen, while the other is from a .22 caliber firearm.

Miscellaneous. One hundred and five miscellaneous artifacts from 38AK287 include ten pieces of unidentifiable heavy metal scrap, 17 pieces of unidentifiable thin metal scrap, and one ebonite fragment which may be from a radio or other electrical appliance. Forty three glass shards included 17 flat specimens that may represent both window pane fragments and such things as picture glass and watch faces, and 26 amorphous, unidentifiable pieces.

\section{AK466: Results of Field Investigations}

Site 38AK466 is a new site discovered during survey of the relocated utility easement (Figures 7 and 36; Table 10). The site is situated on a ridge top along the western margin of Upper Three Runs Creek and is characterized as multicomponent with an unknown prehistoric occupation as well as an early twentieth century residence. A standing structure at the site was observed on the 1943 and 1951 aerial photographs [United States Atomic Energy Commission Aerial Photographs (USAECAP) 1943, 1951]. The location of the historic structure is shown Figure 37. A cruciform pattern of shovel tests was employed to evaluate the spatial extent of subsurface deposits. Of the eight shovel tests excavated, only two were positive and yielded prehistoric artifacts. These positive tests were $20 \mathrm{~m}$ apart and both were in the utility easement. Site boundaries, estimated at $50 \times 80 \mathrm{~m}$, were delineated on the basis of a surface scatter of historic period artifacts that had been disturbed when the site was clearcut in 1982.

\section{Artifact Analysis: $38 A K 466$}

A total of 27 artifacts was recovered from surface and subsurface contexts during the recent investigations of 38AK466. Descriptions of these artifacts by class and type are presented in the following subsections. 


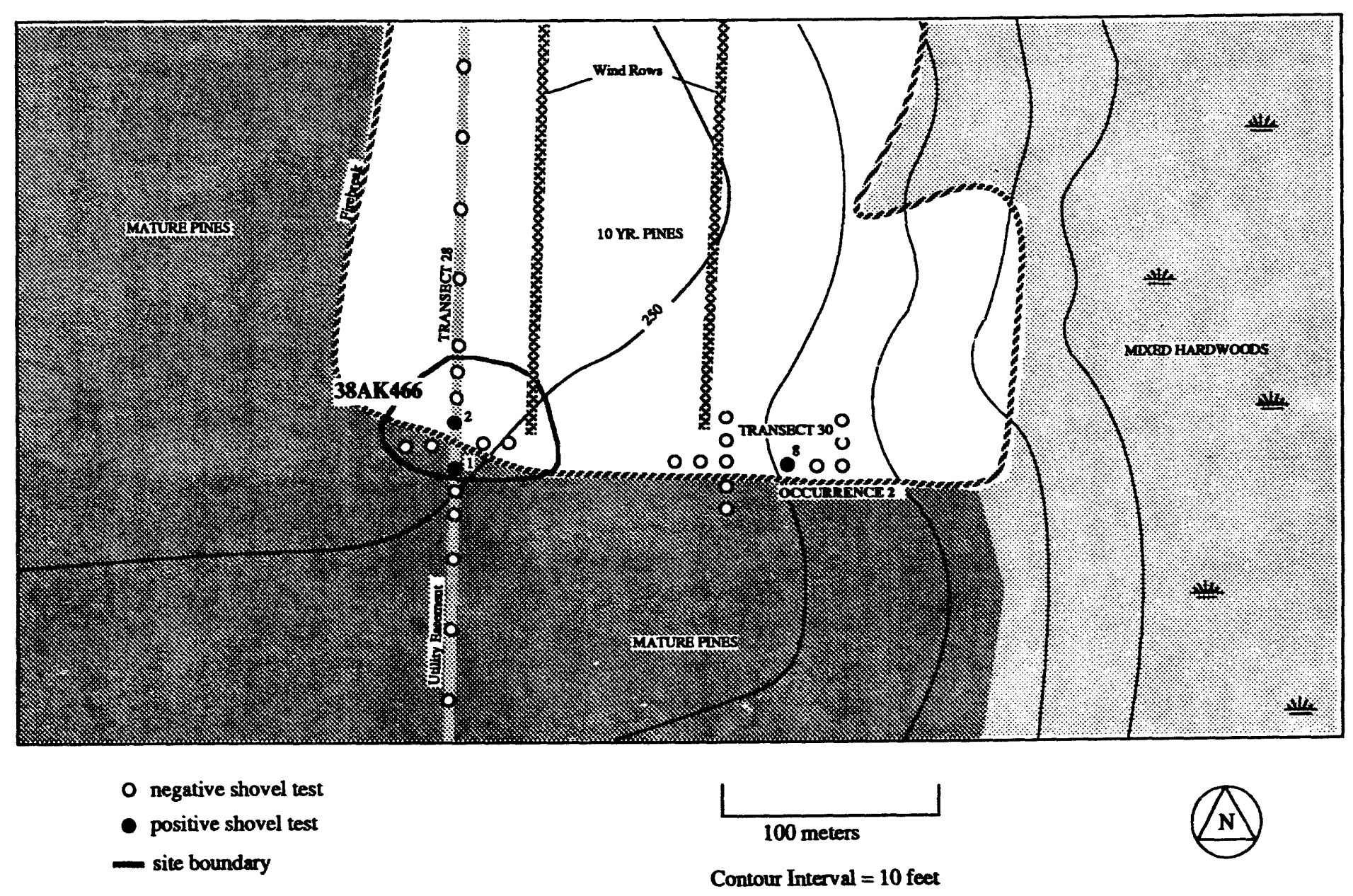

Figure 36. Site map for 38AK466. 
Table 10. Specifications for Site 38AK466.

\begin{tabular}{ll}
\hline Cultural Components & Unk prehistoric; Twentieth century \\
Descriptive Site Type & Lithic scatter; Home place \\
Site Dimensions & $50 x 80 \mathrm{~m}$ \\
Depth of Cultural Material & Surface and $10-60 \mathrm{~cm} \mathrm{BS}$ \\
Landform Location & Ridge top \\
Elevation AMSL & $250 \mathrm{ft}$ \\
Elevation Above Nearest Rank 3 Stream & $60 \mathrm{ft}$ \\
Distance to Water: & $950 \mathrm{~m}$ \\
Soil Type & Lakeland \\
Soil Classification & Sand \\
Soil Description & Excessively drained \\
Ground Cover & Heavy \\
\hline
\end{tabular}

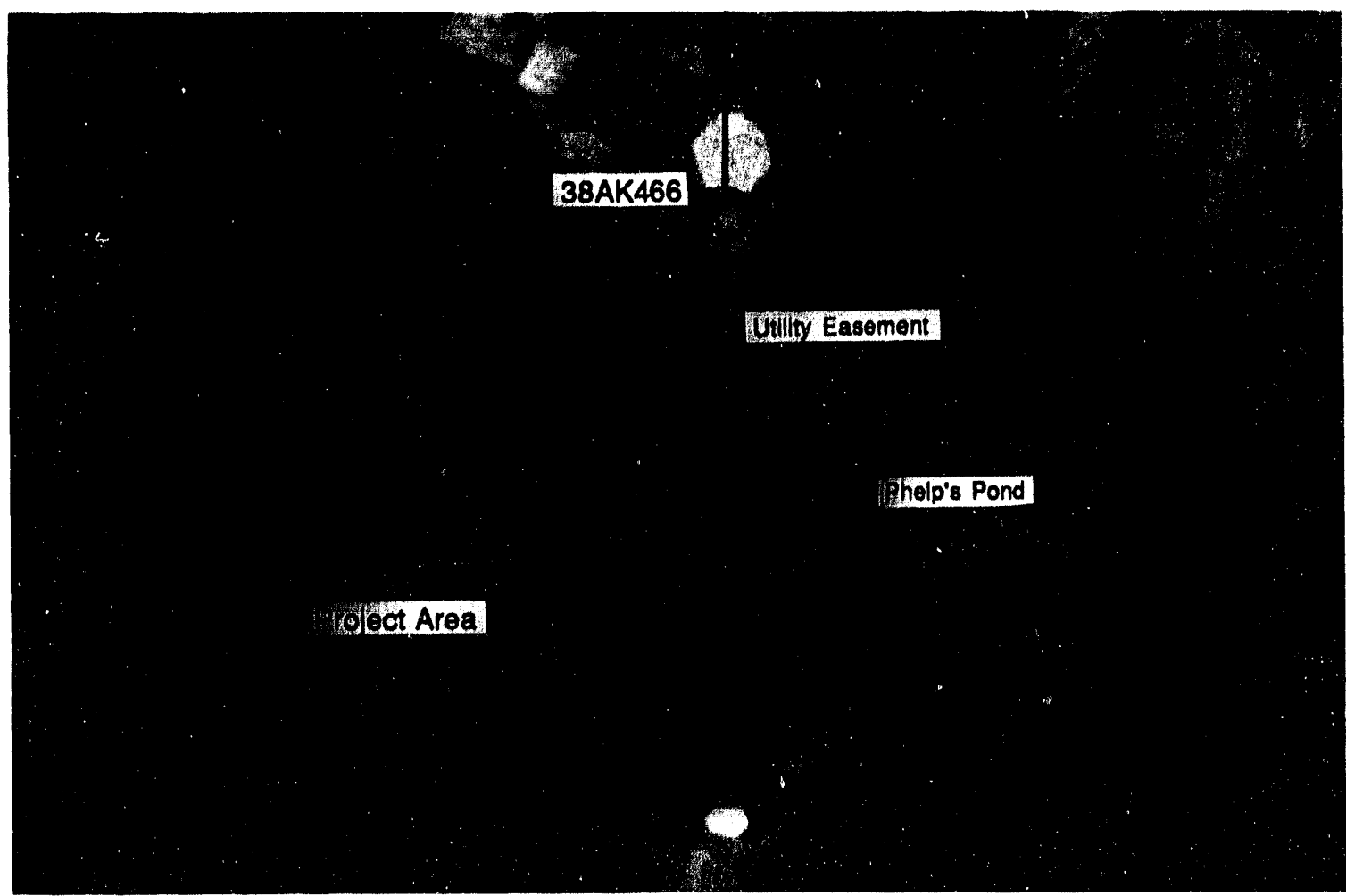

Figure 37. 1951 aerial photograph showing structure location at 38AK466.

\section{Prehistoric Artifacts.}

The prehistoric assemblage contains 12 pieces of prehistoric lithic debitage inventoried by provenience in Table 11. The collection includes one chunk of chert from a surface context and 11 flakes recovered in shovel tests between 10 and $60 \mathrm{~cm} \mathrm{BS}$. Besides the single chert chunk, the debitage consists of small biface thinning flakes. Only one of the flakes are whole. The majority of debitage is Coastal Plain chert. None of the artifacts are time sensitive and a temporal placement for the prehistoric component is not possible. 
Table 11. Prehistoric Artifact Inventory by Provenience, 38AK466.

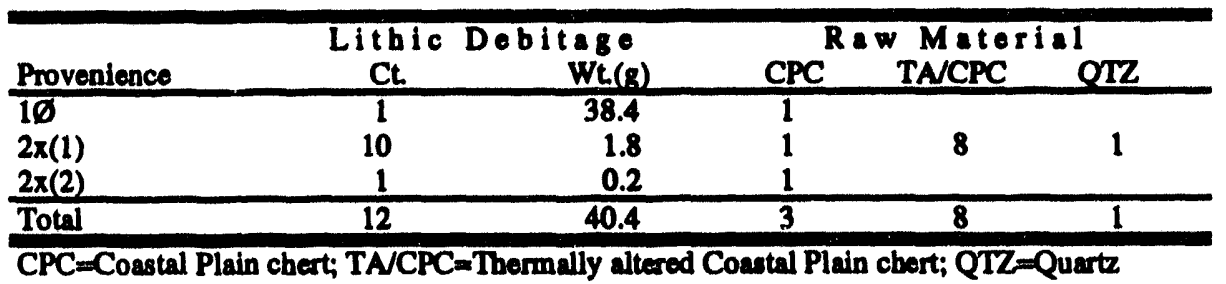

\section{Historic Artifacts}

The historic assemblage, summarized in Table 12, contains 15 artifacts, all from surface contexts. The collection consists of ceramics, kitchen-related ware, and one miscellaneous item. An assemblage inventory by provenience is given in Appendix I.

Ceramics. Eleven sherds were recovered at 38AK466. Of these, only one was decorated--an embossed ironstone/whiteware teacup handle. One teacup base and three rims (one from a bowl and two from teacups), together with five amorphous sherds of unidentifiable morphology make up the remainder of the refined earthenware from the site. A coarse redware Herty cup base was also recovered from the surface. Standing approximately $22 \mathrm{~cm}$ tall, Herty cups were first manufactured in the late nineteenth or early twentieth centuries, and were used to collect pine tree gum for the manufacture of naval stores. They were used at least into the 1930 s, when they sold for $\$ 250$ per 10,000 (Bond 1987:190; Campbell 1933:29).

The eleven sherds recovered from 38AK466 represent at least nine different vessels. These include the Herty cup, three ironstone/whiteware teacups, one ironstone/whiteware bowl, and four ironstone/whiteware vessels of unknown morphology. Of these, three of the ironstone/whiteware vessels exhibit a blue tint to the glaze, while the remainder have a white or slightly creamy cast.

Kitchen. The three kitchen-related artifacts recovered at 38AK466 include two shards of a canning jar and one canning jar zinc lid liner.

Miscellaneous. One piece of iron scrap consisting of an eye on the end of a bent rod $14 \mathrm{~cm}$ long was found at 38AK466. Its function is unknown.

Table 12. Frequencies of Historic Artifacts by Analytical Class, 38AK466.

\begin{tabular}{lcc}
\hline Class & Absolute & Relative \\
\hline Ceramics & Prequency & Prequency \\
Kitchen & 11 & 73.3 \\
Miscellaneous & 3 & 20.0 \\
\hline TOTAL & 1 & 6.7 \\
\hline \hline
\end{tabular}




\section{SITES OUTSIDE THE AREA OF DIRECT IMPACT}

Survey efforts along the original, and subsequently modified, utility easement were intended to relocate four previously recorded sites (38AK274, 38AK282, 38AK283, $38 \mathrm{AK} 288$ ) and to determine if their boundaries extended into the easement. One of these sites, 38AK288, was relocated and limited archaeological work was conducted to determine its extent. Transect shovel tests were also employed to relocate 38AK282 but no artifactual evidence of the site was found. Before any further attempt to locate sites was initiated, the easement location was revised and survey shifted to this new area. Consequently, sites 38AK274 and 38AK283 were not revisited. Although these resources will not be affected by proposed construction, the following sub-sections include brief site descriptions and full documentation of field investigations conducted at the sites.

\section{AK288: Results of Field Investigations}

Site 38AK 288 is situated on a small ridge nose on the western margin of Upper Three Runs Creek (Figures 7, 17, 18; Table 13). The site was initially discovered in November of 1982 during a stratified random sample survey of Upper Three Runs. In August of 1983, intensive testing was conducted at 38AK288 to delineate site boundaries, to evaluate the integrity of subsurface deposits, and to obtain an adequate sample of artifacts for determining site chronology. Site testing entailed the excavation of 18 shovel tests in a cruciform pattern and four adjoining test units. This effort led to the discovery of buried Woodland and Archaic remains to a minimum depth of $60 \mathrm{~cm}$ BS. Expansion of the initial $2 \times 2 \mathrm{~m}$ unit to a total of $8 \mathrm{~m}^{2}$ yielded an assemblage of plain fibertempered and various types of sand-tempered pottery in the upper $30 \mathrm{~cm}$. Savannah River Stemmed bifaces, other bifaces, debitage, and two soapstone disk fragments were also recovered. Pottery was not found deeper than $30 \mathrm{~cm}$, but Early Archaic utilization of the site was demonstrated by the recovery of two exhausted Edgefield scrapers from 30$60 \mathrm{~cm}$ BS. Based on the results of the 1982 testing project, 38AK288 has demonstrable potential for the study of Early Archaic and ceramic Late Archaic utilization of remote tributary locations.

Although a cruciform pattern of shovel tests was dug at the site in 1982, site boundaries had not been properly defined according to established SRARP procedures (SRARP 1990:15-16). To more accurately delineate the western extent of 38AK288 where the original easement should have crossed, shovel tests were excavated in a northeast direction beginning at a point $20 \mathrm{~m}$ from the last shovel test dug in 1983 . Fortunately, the 1983 STPs were still open because they were not routinely backfilled in the early years of the SRARP. Five tests were dug on a line designated Provenience 11, as provenience numbers 1-10 were assigned to earlier excavations. Based on three positive tests along Provenience 11 (STPs 1-3) and one positive test along Transect 22 (STP 3) (Figure 17), the area of 38AK288 was increased to $75 \times 200 \mathrm{~m}$. Despite this expanded boundary, 38AK288 lies well outside of the relocated utility easement.

\section{Artifact Analysis: $38 A K 288$}

A total of 32 artifacts was recovered from four shovel tests at 38AK288 during the present fieldwork (Table 14). The assemblage contains 27 pieces of prehistoric lithic debitage, one other biface tip, and four potsherds. The debitage consists of small biface thinning flakes, most of which are Coastal Plain chert. One quartz and one metavolcanic flake are present in the assemblage. Two of the ceramic sherds are sand tempered plain 
Table 13. Specifications for Site 38AK288.

\begin{tabular}{ll}
\hline Cultural Components & Early Archaic - Late Woodland \\
Descriptive Site Type & Multifunctional prehistoric component \\
Site Dimensions & $75 \times 200 \mathrm{~m}$ \\
Depth of Cultural Material & $0.60 \mathrm{~cm} \mathrm{BS}$ \\
Landform Location & Ridge nase \\
Elevation Above MSL & $220 \mathrm{ft}$ \\
Elevation Above Nearest Rank 3 Stream & $30 \mathrm{ft}$ \\
Distance to Water: & $500 \mathrm{~m}$ \\
Soil Type & Troup, Vaucluse-Ailey \\
Soil Classification & Sand \\
Soil Description & Well drained \\
Ground Cover & Heavy \\
\hline
\end{tabular}

Table 14. Artifacts Recovered from 38AK288 by Shovel Test.

\begin{tabular}{|c|c|c|c|c|}
\hline $\begin{array}{l}\text { Shovel } \\
\text { Test }\end{array}$ & $\begin{array}{l}\text { Lithic } \\
\mathrm{Ct} \text {. }\end{array}$ & $\begin{array}{r}\text { Debitage } \\
\text { Wt. (g) }\end{array}$ & $\begin{array}{l}\text { Lithic } \\
\text { Tools }\end{array}$ & Pottery \\
\hline $11 \times(1)$ & 4 & 0.5 & $1^{a}$ & $1^{b}$ \\
\hline $11 \times(2)$ & 18 & 5.1 & & $1^{c}$ \\
\hline $11 \times(3)$ & 2 & 0.2 & & $1^{d}$ \\
\hline Transect 22(3x) & 3 & 2.6 & & $1^{e}$ \\
\hline Total & 27 & 8.4 & 1 & 4 \\
\hline
\end{tabular}

and a third is an eroded "crumb" sherd. The only diagnostic artifact is a single rectilinear complicated sherd (Figure $32 \mathrm{~b}$ ) that is probably indicative of a Late Woodland-Early Mississippian transition occupation.

\section{$38 A K 274$}

Site 38AK274 was located in November of 1982 during a clearcut survey (Figure 7). A site revisit was made in August of 1983. The site is located on a terrace edge on the western margin of Upper Three Runs Creek. Based on the extent of a surface scatter of prehistoric and historic artifact, site size was estimated at $30 \times 50 \mathrm{~m}$. Surface collected diagnostic artifacts indicate that prehistoric occupations occurred during the Early, Middle, and Late Woodland periods, and that historic settlement was primarily during the late eighteenth and early nineteenth century.

\section{$38 A K 282$}

Site 38AK282 was located in November of 1982 during a clearcut survey (Figure 7). A site revisit was made in August of 1983. The site is situated on a ridge nose on the western margin of Upper Three Runs Creek. Based on the extent of a surface scatter of prehistoric and historic artifact, site size was estimated at $50 \times 50 \mathrm{~m}$. Surface collected diagnostic artifacts indicate that prehistoric occupations occurred during the Early, Middle, and Late Woodland periods, and that historic settlement was primarily during the late nineteenth and early twentieth century. 
Site 38AK282 was located in November of 1982 during a clearcut survey (Figure 7). A site revisit was made in August of 1983. The site is situated on a ridge nose on the western margin of Upper Three Runs Creek. Based on the extent of a surface scatter of prehistoric artifacts, site size was estimated at $50 \times 50 \mathrm{~m}$. Surface collected diagnostic artifacts indicate that prehistoric occupations occurred during the Early, Middle, and Late Woodland periods.

\section{SUMMARY AND CONCLUSIONS}

The results of survey for the SREL Conference Center provide adequate data to draw some conclusions about site occupational history and site function. Together with the conceptual material discussed in Chapter 2, the data are adequate to assess the research potential of sites 38AK287, 38AK289, and 38AK466.

\section{Prehistoric Period Occupation Sequence and Site Use}

Evidence for the earliest human occupation of the project area is found in the area of direct impact at sites 38AK287 and 38AK289, and outside the area of direct impact at 38AK288. Several diagnostic hafted bifaces and unifaces attest to site use during the Early Archaic period, roughly 9500-8000 B.P. These tools are found in association with small, patinated flakes and a few utilized flakes. Compared to the diverse assemblages of Early Archaic tools and lithic by-products at sites such as Lewis-East (38AK228E) and Pen Point (38AK383) along the Savannah River (Sassaman et al. 1990:91-96; 100-104), the project area assemblages represent a limited range of activities. Additionally, the project area assemblages are small clusters of tools and debitage spaced widely over the terrace and ridge. These patterns are consistent with a model of limited, short-term site use by small groups dispatched from lowland base camps (see Chapter 2). What is more interesting about the project area assemblages is the diversity of raw materials evident in the small sample of hafted bifaces. Similar diversity is seen in other upland sites in the Upper Three Runs drainage (Sassaman 1992b), and this suggests that upland land-use in the area was not limited to groups dispatched from Savannah River Valley camps, where Allendale chert forms the vast majority of lithic assemblages. Thus, as outlined in Chapter 2, the project area Early Archaic assemblages provide the opportunity to examine the possibility that groups originating from sites along the Edisto River and other Coastal Plain-draining rivers visited the area. While this may appear to be a particularistic issue, the ramifications for studies of settlement mobility and regional population integration are indeed important. This research potential is further enhanced by the buried contexts of the Early Archaic assemblages. The major drawback is the limited distribution of these materials. Because the clusters producing these relevant data are small and widely spaced across the project area, they are difficult to isolate through shovel testing. Ironically, adequate testing to locate the clusters has the potential to effectively capture most, if not all, of the relevant information. These are problems of data recovery that need to be assessed independently of the research questions used to evaluate site significance. In this regard, the Early Archaic resources within the project area are without a doubt significant.

Other prehistoric occupations in the project area are represented by a limited amount of lithic and ceramic material. The lack of more substantial Late Archaic and Early Woodland assemblages is surprizing given the abundant and extensive distribution of these components elsewhere in the Aiken Plateau. Nevertheless, the co-occurrence of lithic tools and ceramic sherds of this period signify at least small-scale seasonal habitation consistent with the settlement models discussed in Chapter 2. Other than the 
low-density of such material, there is nothing about the Late Archaic-Early Woodland record of the project area sites that causes us to question extant interpretations. The value of these limited resources is thus somewhat eclipsed by better and more numerous examples elsewhere in the vicinity. A similar argument can be made for Middle and Late Woodland components within the project area

Minor evidence for Early Mississippian site use at 38AK289 is indicated by two small, decorated sherds. Other Mississippian period settlements with Savannah II components (ca. A.D. 1200) have been located along the floodplain of Upper Three Runs Creek (Sassaman et al 1990:300). These are typically small sites represented by low densities of pottery. Anderson (1990:488-490) has surmised that distribution of Mississippian sites on the SRS is linked to the location of paramount centers in the basin. Based on archaeological and spatial data, he suggests that Early Mississippian sites along Upper Three Runs were affiliated with the Mason's Plantation and Hollywood mound groups some 15 to $20 \mathrm{~km}$ to the north. Most Mississippian sites on the SRS are assumed to be perennial habitation areas, although none have been investigated thoroughly enough to resolve function (Anderson 1990:486-488). The likely Mississippian component at 38AK289 probably represents a small homestead whose occupants exploited the floodplain for agricultural purposes.

\section{Historic Period Occupation Sequence}

The three Euro-American sites in the project area appear to represent four distinct occupation phases (Table 15; Figure 38). Phase one started between ca. 1768 and ca. 1790. Represented by the eastern extent of 38AK289 (Transects 19, 20, 21, and 24), this occupation probably represents the residency of Elkanah Green or a tenant on his property. Green had the property surveyed in 1793, which may well represent the initial occupation date. However, it is possible that someone lived on the property prior to the survey date, since Green does not appear in the Barnwell County Deed Book and received his land by state grant. In any case, 1793 seems to be the latest date at which occupancy of the site would have begun. Although no trace of a structure was recovered in Test Units 1 or 3, the variety of nail types (wrought, wrought with cut heads, and cut with cut heads) indicates that at least one building stood somewhere in the immediate vicinity, and that there may have been several construction or repair episodes at the site. Similarly, the combination of colonoware, creamware, pearlware, alkaline glazed stoneware, and wine bottle glass strongly indicates that these transects and Test Units 1 and 3 intercepted a yard area sheet midden incorporating material from both utilitarian contexts (the alkaline glazed stoneware and colonoware) and domestic contexts (creamware, pearlware, and wine bottle glass). The colonoware may represent the presence of a slave or slaves on the site in this initial occupation phase.

Phase two of the occupation sequence is represented by the west margin of 38AK289 (Transect 23). Occupation of this portion of the site may have started as early

Table 15. Artifactual Sources of Chronometric Data.

\begin{tabular}{lcccc}
\hline Artifact & 38AK289 & 38AK289 & & \\
Category & Trans. 19-21, 24 & Tran. 23 & 38AK287 & 38AK466 \\
\hline Architecture & ca. $1790-1900$ & na & ca. 1845-1890 & na \\
Glass & na & na & ca. 1875-1890 & na \\
Ceramics & $1768-c a .1840$ & ca.1820-1880 & ca. $1845-1870$ & ca. 1900-1950 \\
Arms-Related & na & na & ca. 1890-1950 & na \\
Kitchen & $?-$ ca. 1880 & na & na & na \\
\hline
\end{tabular}




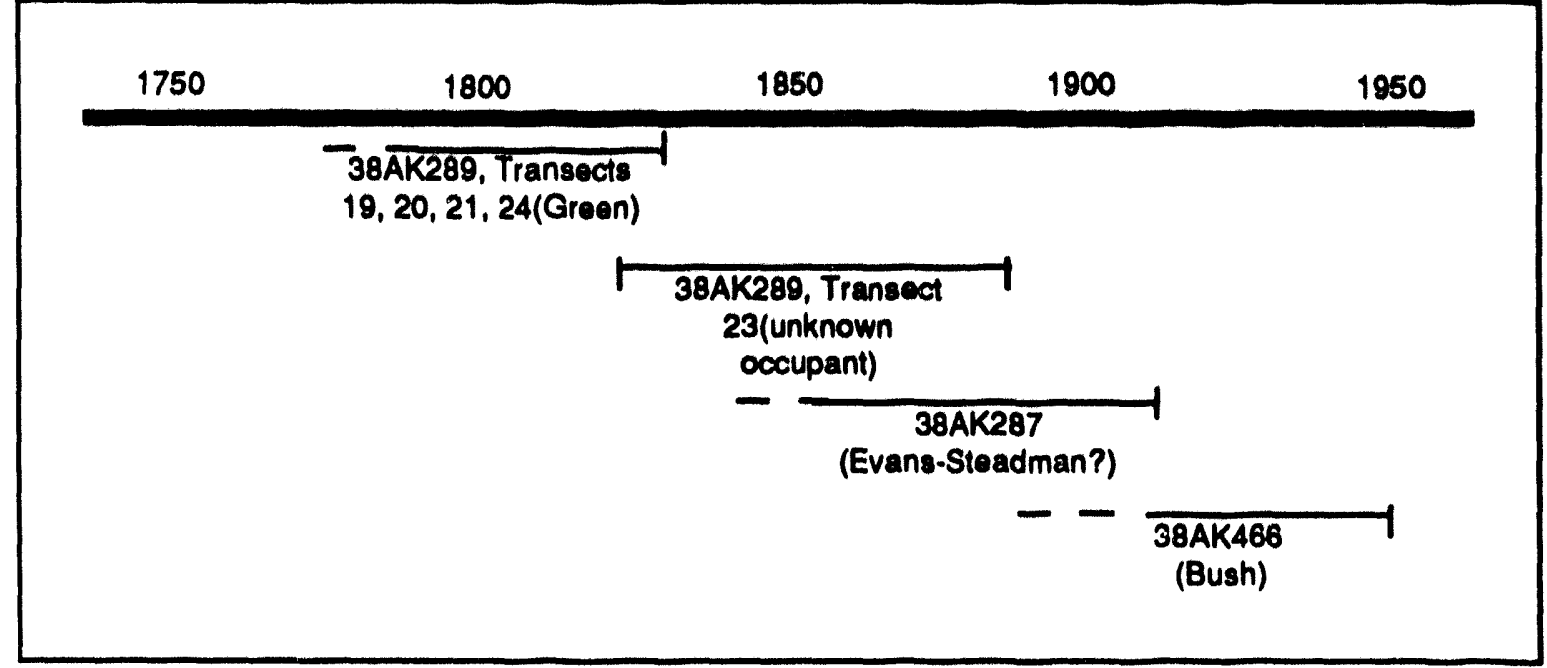

Figure 38. Euro-American occupation sequence of the project area.

as ca. $1820-30$ and probably continued into the $1870 \mathrm{~s}-1880$ s. It is represented by the banded ironstone/whiteware sherd, the dark blue transfer-printed plate marley dating from the $1820 \mathrm{~s}-30 \mathrm{~s}$, and the alkaline-glazed stoneware. Interestingly, one of the alkalineglazed sherds has a natural slipped interior, possibly representing a manufacture date in the late nineteenth century, when Albany, Ohio, and other natural slips gradually replaced the traditional wood-ash glaze used by area potters. Little else is known about this occupation phase, as it appears to fall into the chronological gap in the chain of title.

Phase three of the occupation sequence is represented by $38 \mathrm{AK} 287$, which based on the relatively scarce diagnostic artifacts from the site, appears to have been initially settled sometime after ca. 1840 (the approximate date at which pearlware disappears from the archieological record). This initial settlement date is supported by the presence of cut nails (and paucity of wire specimens) and alkaline-glazed stoneware. Occupation of this site probably lasted into the late nineteenth century, based on the presence of manganesedecolored glass, canning jar, and soda bottle fragments. Based on the dearth of decalcomania-decorated ironstone whiteware, wire nails, and other early twentieth century diagnostic artifacts, occupation of this site may have ended prior to ca. 1890 . It certainly ended before 1921 , since a topographic map surveyed in that year shows no structures at this location (United States Army Corps of Engineers [USCOE] 1921). This site may relate to the Evans-Steadman ownership period, which ended in 1888 with the sale of the property at a sheriff's auction to J. Henry Busch, who had been the previous landowner.

Phase four of the occupation sequence probably started in the closing decades of the nineteenth century or the early decades of the twentieth at 38AK466. The only temporal diagnostic from this site is the redware Herty Cup, which was used starting ca. 1900. However, the paucity of earlier material tends to support a late-nineteenth or early twentieth century date for the initial occupation of this site. Interestingly, the presence of ironstone/whiteware tablewares and canning jar shards may indicate that this site combined both domestic and extractive functions. This site is evident as a structure on both on the 1921 topographic map (USACOE 1921), as well as 1943 and 1951 aerial photographs [United States Atomic Energy Commission Aerial Photographs (USAECAP) 1943, 1951]. The building may have been built during the Busch family tenure, which with a brief hiatus in 1898, lasted from 1888 to 1916 . In 1916 the property was sold to W. W. Holley, Jr., by E. H. and Ellie C. Busch. 


\section{CHAPTER 5 \\ CONCLUSIONS AND RECOMMENDATIONS}

Intensive archaeological survey within the 70-acre project area and easements of the proposed SREL Conference Center was conducted on 43 days between August 19, 1992 and January 15, 1993 by personnel of the Savannah River Archaeological Research Program. A total of 400 shovel test pits were excavated along transects to sample and delineate the boundaries of existing sites, and to discover new sites. In addition, 14 test units amounting to $25 \mathrm{~m}^{2}$ were excavated to sample portions of sites in the areas of direct impact, particularly in the footprint of the Conference Center.

Six previously recorded sites, one new site, and two new artifact occurrences were implicated in this project. Because the design of the Conference Center was altered in consultation with SREL personnel to avoid excessive impacts to one of the sites (38AK289), four of the previously recorded sites and the artifact occurrences were no longer implicated. Thus, determinations of eligibility to the National Register of Historic Places and management recommendations are required for only three sites, 38AK287, $38 \mathrm{AK} 289$, and 38AK 466. Table 16 summarizes this information.

Table 16. Evaluation and Recommendations for Sites Within the Proposed SREL Conference Center and Educational Facility.

\begin{tabular}{lllll}
\hline Site & Components & NRHP & & \\
Eligibility & Integrity & Recommendations \\
\hline 38AK287 & Early Arch., Barly-Mid Wdid., late 19th-20th contury & Yos & Good & Avoid \\
38AK289 & Early Arch.-Middlo Wdld., 18th-20th contury & Yes & Good & Avoid \\
38AK466 & Indetorminete prehistoric, 20th contury & No & Poor & No Purther Work \\
\hline
\end{tabular}

Site 38AK287 is a multicomponent site some $35 \times 70 \mathrm{~m}$ in size that will be intercepted by the proposed utility easement of the Conference Center. Subsurface testing produced evidence for buried Early Archaic and Early-Middle Woodland components, as well as shallow and surficial remains dating to the late nineteenth century. The Early Archaic deposits are especially relevant to current debates concerning the organization and integration of early Holocene populations in the region. As specified in Chapter 2, data on the raw material content and the stylistic variability of lithic assemblages from this period are important to our interpretations of settlement mobility, exchange, and social organization. In addition, the late nineteenth-early twentieth century deposits at 38AK287 have some potential to provide information relevant to our understanding of regional economic development of the modern era.

Site 38AK289 is characterized as multicomponent with occupations dating from the Early Archaic to the early twentieth century. The site is situated on a prominent terrace landform overlooking the floodplain of Upper Three Runs Creek and occupies much of the project area. Based on information obtained from intensive shovel testing, cultural remains at $38 \mathrm{AK} 289$ cover an area approximately $400 \times 550 \mathrm{~m}$ on portions of a ridge top, ridge side slope, and terrace edge. Test units excavated document artifact deposits extending to at least one meter below the surface. These deposits are especially well-stratified for an upland site.

Shallow components of significance within 38AK289 include the remains of eighteenth century occupations along the eastern margin of the site. Historic era components of this age are rare in the Aiken Plateau, as most of the documented early 
settlement and economic development unfolded along the terraces of the Savannah River and comparable waterways. Thus, the early historic components at 38AK287 are relevant to our increasing understanding of backcountry history, particularly processes of economic and social development on the fringe of what might be described as a semiperiphery.

The eastern margin of 38AK289 likewise contains buried Late Archaic deposits that are indicative of at least seasonal habitation by small groups. As discussed in Chapter 2, our model of settlement organization during this period is one of aggregation and dispersal involving relatively large settlements along the Savannah River and small, seasonal encampments in Aiken Plateau. However, an alternative model involving interdrainage sites is brought to the fore because of the remoteness of the project area from the Savannah River. The nearby site 38AK288, for instance, has produced plain fiber-tempered pottery that more closely resembles the Late Archaic pottery of the Coastal Plain-draining Salkahatchie and Coosawhatchie valleys than it does the typical Stallings pottery from the Savannah River Valley. The sociopolitical affiliation of Late Archaic occupants of sites in the project area is of critical relevance to interpretations of regional organization because these groups either constituted the fundamental economic and social cogs of large-scale cultural formations in the Savannah Valley, or, alternatively, they represented social and economic options that may have contributed to the demise of such formations. Late Archaic remains along the eastern margin of 38 AK289, like those from $38 \mathrm{AK} 288$, have the potential to yield information to address these types of questions.

Other components of 38AK289 are distributed widely over the site where they occur at various depths below surface. Among them are a series of Early Archaic artifact clusters with research potential similar to those of 38AK287. In general, these resources are located some $70-100 \mathrm{~cm}$ below surface, but they are small, discontinuous clusters that are probably not contemporaneous. The relocated footprint for the Conference Center lies over one of these clusters. Close interval testing in and around the footprint produced an assemblage sample that is tantalizing with respect to the regional-scale questions raised in Chapter 2. However, we do not feel that excavation of sufficient scale to locate and remove the remaining artifacts of the cluster is warranted. Although the sample recovered has properties relevant to regional-scale issues of Early Archaic organization, it does in fact represent only limited activities, probably hunting, meat and hide processing, and tool discard. Considering that several other buried clusters of similar function are located in portion of 38AK289 to be avoided, as well as 38AK287 and 38AK288, data recovery for Early Archaic remains below the proposed Conference Center footprint is not recommended.

With final regard to 38AK289, evidence for a late eighteenth century component was located along the western margin of the site. Like its historic-era counterpart on the eastern margin of the site, this component has the potential to yield information relevant to the study of backcountry economic and social development. Because it is well outside the immediate footprint for the Conference Center, there will be no adverse effects to this part of the site.

Finally, site $38 \mathrm{AK} 466$ is located in the proposed easement for a utility line that will extend northward from the proposed Conference Center. It is a small, disturbed site with an unidentified prehistoric component and the scattered remains of an early twentieth century farmstead. The prehistoric assemblage is limited to several pieces of lithic debitage indicative of tool maintenance and replacement. This limited assemblage is typical of upland prehistoric sites distant from sources of running water. It contains no evidence for domestic activities or other types of site functions that would lend new 
information about the organization of prehistoric societies in the region. The historic period component to 38AK466 includes artifacts that have the potential to elucidate the lifeways of tenant farmers in the early part of this century, but the archaeological integrity of their context has been compromised by recent land-use practices, especially the building relocation/razing efforts that took place in 1951 when the Atomic Energy Commission acquired land for the SRS.

\section{Recommendations}

Sites 38AK287 and 38AK289 have sufficient artifactual content and archaeological integrity to yield information important to our understanding of prehistory and history in the region. These sites are thus considered eligible for nomination to the National Register of Historic Places (NRHP). Accordingly, the Savannah River Archaeological Research Program (SRARP) recommends

\section{that Savannah River Field Operations Office of the Department of Energy request from the South Carolina State Historic Preservation Office a determination of no effect through mitigation of adverse effects from construction of the SREL Conference Center for sites 38AK287 and 38AK289.}

Mitigation of adverse effects on sites 38AK287 and 38AK289 can be achieved through preservation. Given the limited scale of the adverse effects in the proposed project, preservation of these resources is possible through avoidance. Adverse effects to 38AK287 can be altogether avoided by either spanning the utility line over the site, or, if this is undesirable or impossible, by diverting the utility easement some $25-30 \mathrm{~m}$ to the west.

Site 38AK289 will be difficult, if not impossible, to completely avoid because of its large expanse. However, the most significant portion of the site-shallow deposits along the terrace edg; dating from the Late Archaic period through the early twentieth century-has already been avoided by relocating the proposed Conference Center footprint upslope some $200 \mathrm{~m}$ from the terrace edge. The portion of 38AK289 on which the relocated footprint lies contains relatively deep Early Archaic deposits, but these are duplicated by similar deposits elsewhere in the avoided portion of 38AK289, at $38 \mathrm{AK} 287$, and at the nearby site 38AK288. Because of this resource redundancy, and considering the limited subsurface disturbance construction of the Conference Center will entail, the proposed action will constitute an avoidance of impact and will thus have no adverse effect on 38AK289.

Site 38AK466 lacks sufficient artifactual content and archaeological integrity to have the potential to yield information important to our understanding of prehistory or history. The site is therefore not considered eligible for nomination to the National register of Historic Places. Accordingly, the Savannah River Archaeological Research Program (SRARP) recommends

that Savannah River Field Operations Office of the Department of Energy request from the South Carolina State Historic Preservation Office a determination of no effect from construction of the SREL Conference Center for site $38 A K 466$.

The SRARP will be at the disposal of SREL engineers and designers to assist in assuring that avoidance recommendations are met. This will simply involve flagging $38 \mathrm{AK} 287$ and the downslope portion of 38AK289. 
Finally, the SRARP stresses that sites 38AK287 and 38AK289 are eligible for nomination to the NRHP and are therefore afforded consideration under Section 106 of the National Historic Preservation Act for evaluation of any future, but currently unforeseen, impacts stemming from the operation, maintenance, and/or expansion of the SREL Conference Center. Irrespective of future planned development, the SRARP recommends that the SREL ensure continuous preservation of the archaeological resources through an active program of education and site monitoring. The SRARP is available to work with SREL to guarantee long-term preservation of resources. 


\section{REFERENCES CITED}

Anderson, David G.

1990 Political Change in Chiefdom Societies: Cycling in the Late Prehistoric Southeastern United States. Unpublished Ph.D. dissertation, Department of Anthropology, University of Michigan, Ann Arbor.

Anderson, David G., David J. Hally and James L. Rudolph

1986 The Mississippian Occupation of the Savannah River Valley. Southeastern Archaeology 5:32-51.

Anderson, David G. and Glen T. Hanson

1988 Early Archaic Settlement in the Southeastem United States: A Case Study from the Savannah River Valley. American Antiquity 53:262-286.

Barry, J. M.

1980 Natural Vegetation of South Carolina. University of South Carolina Press, Columbia.

Blackall, Henry

1876 Nails. American Architect and Building News 24:71-74.

Bond, Stanley

1987 The Development of the Naval Stores Industry in St. Johns County, Florida. The Florida Anthropologist 40 (3):187-203.

Braley, Chad O.

1992 Cultural Resources Survey of Selected (FY91) Timber Harvesting Areas on Fort Jackson, Richland County, South Carolina. Report submitted to the U.S. Army Corps of Engineers, Savannah District. Prepared jointly by Gulf Engineers and Consultants, Baton Rouge, Louisiana and Southeastern Archaeological Services, Athens, Georgia.

Braley, Chad O. and T. Jeffrey Price

1991 Cultural Resources Survey of Selected (FY90) Timber Harvesting Areas, Fort Gordon, Richmond and Columbia Counties, Georgia. Report submitted to the U.S. Army Corps of Engineers, Savannah District and the Division of Forestry and Engineering, Fort Gordon.. Prepared jointly by Gulf Engineers and Consultants, Baton Rouge, Louisiana and Southeastern Archaeological Services, Athens, Georgia.

Brooks, Mark J.

1990 A Point-Bar Site on the South Edisto River in the Upper Coastal Plain of South Carolina: Depositional History and Environmental Implications. South Carolina Antiquities 22:17-25.

Brooks, Mark J. and Donald J. Colquhoun

1991 Late Pleistocene-Holocene Depositional Change in the Coastal Plain of the Savannah River Valley: A Geoarchaeological Perspective. Early Georgia 19(2):120. 
Brooks Mark J. and Glen T. Hanson

1987 Late Archaic-Late Woodland Adaptive Stability and Change in the Steel Creek Watershed, South Carolina. Draft report submitted to Savannah River Operations Office, U.S. Department of Energy. Manuscript on file, Savannah River Archaeological Research Program, South Carolina Institute of Archaeology and Anthropology, University of South Carolina.

Brooks, Mark J. and Kenneth E. Sassaman

1990 Point Bar Geoarchaeology in the Upper Coastal Plain of the Savannah River Valley, South Carolina: A Case Study. In Archaeological Geology of North America, edited by N.P. Lasca and J. Donahue. Geological Society of America, Centennial Special Vol. 4:183-197. Boulder, Colorado.

Brooks, Richard D. and David C. Crass

1991 A Desperate Poor Country: History and Settlement Patterning on the Savannah River Site, Aiken and Barnwell Counties, South Carolina. Savannah River Archaeological Research Papers 2. University of South Carolina, Columbia.

Caldwell, Joseph R. and Catherine McCann

1941 Irene Mound Site, Chatham County, Georgia. University of Georgia Press, Athens, Georgia.

Campbell, A. Stuart

1933 Studies in Forestry Resources in Florida III: The Naval Stores Industry. Bureau of Economic and Business Research Economic Series 1 (5). University of Florida, Gainesville.

Claflin, William H., Jr.

1931 The Stalling's Island Mound, Columbia County, Georgia. Peabody Museum of American Archaeology and Ethnology Papers 14(1).

Coe, Joffre L.

1964 The Formative Cultures of the Carolina Piedmont. Transactions of the American Philosophical Society 54(5), Philadelphia.

Daniel, I. Randolph. Jr.

1992 Early Archaic Settlement in the Southeast: A North Carolina Perspective. In Paleoindian and Early Archaic Period Research in the Lower Southeast: A South Carolina Perspective, edited by D. G. Anderson, K. E. Sassaman, and C. Judge, pp.68-77. Council of South Carolina Professional Archaeologists, Columbia.

Dreppard, Charles

1946 Spikes, Nails, Tacks, Brads, and Pins. In Early American Industries Association Chronicle 3(8).

Goodyear, Albert C. and Tommy Charles

1984 An Archaeological Survey of Chert Quarries in Western Allendale County, South Carolina. Research Manuscript Series 195, South Carolina Institute of Archaeology and Anthropology, University of South Carolina, Columbia.

Gurcke, Karl

1987 Bricks and Brickmaking: A Handbook for Historical Archaeology. University of Idaho Press, Moscow. 
Hanson, Glen T., Richard D. Brooks and John W. White

1981 The Human Occupation Along the Steel Creek Floodplain: Results of an Intensive Archaeological Survey for the L-Area Reactivation Project, Savannah River Plant, Barnwell County, South Carolina. Research Manuscript Series 173, South Carolina Institute of Archaeology and Anthropology, University of South Carolina, Columbia.

Holcomb, J. and F. Holcomb

1989 South Carolina Potters and Their wares: The History of Pottery Manufacture in Edgefield's Big Horse Creek Section, Part I (ca. 1810-1825). South Carolina Antiquities 21:11-29.

Jewitt, L.

1972 The Ceramic Art of Great Britain. Ward Lock Repairs, London.

Jones, O., and C. Sullivan

1985 The Parks Canada Glass Glossary for the Description of Containers, Tablewares, Flat Glass, and Closures. Parks Canada, Ottawa.

Jurney, D.

1987 Cut and Wire Nails. In Richland Creek Technical Series V, edited by R. Moir and D. Jurney. Archaeology Research Program, Southern Methodist University, Dallas.

King, Adam and Chad O. Braley

1992 Cultural Resources Survey of Selected (FY92) Timber Harvesting Areas, Fort Gordon, Richmond and McDuffie Counties, Georgia. Report submitted to the U.S. Army Corps of Engineers, Savannah District and the Division of Forestry and Engineering, Fort Gordon.. Prepared jointly by Gulf Engineers and Consultants, Baton Rouge, Louisiana and Southeastern Archaeological Services, Athens, Georgia.

Kroeber, A. L.

1925 Handbook of the Indians of California. Bureau of American Ethnology Bulletin 78, Smithsonian Institution, Washington, D.C.

Langley, T.M. and W. M. Marter

1973 The Savannah River Plant Site. Report DP-1323. Savannah River Laboratory, Aiken, South Carolina.

Ledbetter, R. Jerald

1991 Archaeological Investigations ot Will Branch Sites 9WR4 and 9WR11, Warren County, Georgia. Report submitted to J.M. Huber Corporation, Wrens, Georgia. Southeastern Archaeological Services, Athens, Georgia.

Michie, James L.

1966 The Taylor Point. The Chesopiean 4:123.

Mills, Robert

1979 Atlas of South Carolina. Reprint of 1825 edition. Robert P. Wilkins and John D. Keels, Columbia. 
Nelson, $\mathrm{L}$.

1968 Nail Chronology as an Aid to Dating Old Buildings. History News 23 (1):495-6174.

Noèl Hume, Ivor Noèl

1980 Historical Archaeology. Alfred A. Knopf, New York.

Oliver, Billy C.

1981 The Piedmont Tradition Refinement of the Savannah River Stemmed Point Type. Unpublished M.A. thesis, Department of Anthropology, University of North Carolina, Chapel Hill.

Richardson, Katherine H.

1992 Tract M-1228, Savannah River Site, Aiken County, SC. Manuscript on file with the Savannah River Archaeological Research Program, South Carolina Institute of Archaeology and Anthropology, University of South Carolina.

Rogers, V.A.

1990 Soil Survey of the Savannah River Plant Area, Parts of Aiken, Barnwell and Allendale Counties, South Carolina. United States Department of Agriculture, Soil Conservation Service.

Sassaman, Kenneth E.

1985 A Preliminary Typological Assessment of MALA Hafted Bifaces from the Pen Point Site, Barnwell County, South Carolina. South Carolina Antiquities 17:117.

Sassaman, Kenneth E.

1987 Report of Archaeological Investigations at 38AK158 and 38AKI59, Aiken County, South Carolina. Report submitted to Savannah River Operations Office, U.S. Department of Energy. Manuscript on file, Savannah River Archaeological Research Program, South Carolina Institute of Archaeology and Anthropology, University of South Carolina.

1989 Prehistoric Settlement in the Aiken Plateau: Summary of Archaeological Investigations at 38AK158 and 38AK159, Aiken County, South Carolina. South Carolina Antiquities 21:31-64.

1991 Long-term Habitation for Small-scale Societies in the Aiken Plateau. Paper presented at the Southeastern Archaeological Conference, Jackson, Mississippi.

1992a Early Woodland Settlement in the Aiken Plateau, Archaeological Investigations at 38AK157, Savannah River Site, Aiken County, South Carolina. Savannah River Archaeological Research Program, South Carolina Institute of Archaeology and Anthropology, University of South Carolina. (Draft)

1992b Early Archaic Settlement in the South Carolina Coastal Plain. In Paleoindian and Early Archaic Period Research in the Lower Southeast: A South Carolina Perspective, edited by D. G. Anderson, K. E. Sassaman, and C. Judge, pp. 48-67. Council of South Carolina Professional Archaeologists, Columbia.

1992c Changing Strategies of Biface Production in the South Carolina Coastal Plain. Paper presented at the Annual Meeting of the Society for American Archaeology, Pittsburgh. 
1993 Early Pottery in the Southeast: Tradition and Innovation in Cooking Technology. University of Alabama Press, Tuscaloosa.

Sassaman, Kenneth E. and Mark J. Brooks

1990 Cultural Quarries: Strategies for Scavenging and Recycling Lithic Refuse.

Paper presented at the Southeastern Archaeological Conference, Mobile.

Sassaman, Kenneth E., Mark J. Brooks, Glen T. Hanson and David G. Anderson

1990 Native American Prehistory and History in the Middle Savannah River Valley: Synthesis of Archaeological Investigations on the Savannah River Site, Aiken and Barnwell Counties, South Carolina. Savannah River Archaeological Research Papers 1. University of South Carolina, Columbia.

Savannah River Archaeological Research Program (SRARP)

1989 Archaeological Resource Management Plan of the Savannah River Archaeological Research Program. Report submitted to the Savannah River Operations Office, U.S. Department of Energy. Manuscript on file with the Savannah River Archaeological Research Program, South Carolina Institute of Archaeology and Anthropology, University of South Carolina.

1990 Annual Review of Cultural Resource Investigations by the Savannah River Archaeological Research Program. Report submitted to the Savannah River Operations Office, U.S. Department of Energy.

Shelford, Victor E.

1963 The Ecology of North America. University of Illinois Press, Chicago.

Stevenson, Ann E.

1982 Geomorphic History of a Portion of the Savannah River Floodplain, Barnwell County, South Carolina. Unpublished MA Thesis, Department of Geology, University of South Carolina, Columbia.

Sweezy, Nancy

1984 Raised in Clay: The Southern Pottery Tradition. Smithsonian Institution Press, Washington, D.C.

United States Army Corps of Engineers (USACOE)

1921 South Carolina Talatha Quadrangle Map. United States War Department, Washington, D.C.

United States Atomic Energy Commission Acquisition Land Tract Register (USAECALTR)

1952 Atomic Energy Commission property file M-1228. U. S. Department of Energy Savannah River Operations Office, Aiken, SC.

United States Atomic Energy Commission Aerial Photograph (USAECAP)

1943 Savannah River aerial photograph 1943-134. U. S. Department of Energy, Savannah River Operations Office, Aiken, SC.

United States Atomic Energy Commission Aerial Photograph (USAECAP)

1951 Savannah River aerial photograph 1951-102. U. S. Department of Energy, Savannah River Operations Office, Aiken, SC. 
United States Department of Energy (USDOE)

1992 Environmental Assessment: Construction of the Savannah River Ecology Laboratory Conference Center. United States Department of Energy, Savannah River Operations Office, Environmental and Laboratory Programs Division, Aiken, SC. (Draft)

Watanabe, Hitoshi

1968 Subsistence and Ecology of Northem Food Gatherers with Special Reference to the Ainu. In Man the Hunter, edited by R. B. Lee and I. DeVore, pp. 69-77. Aldine, Chicago.

Whipple, Stephen A.

1978 Report for 1978 on the Research Project: A Gradient Analysis of Bottomland and Swamp Forest of the Savannah River Plant, South Carolina. Report by the Department of Botany, Louisiana State University on file at the Savannah River Ecology Laboratory, University of Georgia.

Whipple, Stephen A., Lynn H. Wellman and Bill J. Good

1981 A Classification of Hardwood and Swamp Forests of the Savannah River Plant, South Carolina. Savannah River Plant National Environmental Research Park Program, Report SR-NERP-6.

Williams, Mark and Gary Shapiro

1990 Lamar Archaeology: Mississippian Chiefdoms in the Deep South. The University of Alabama Press, Tuscaloosa. 

Appendix A. Provenience Data.

\begin{tabular}{|c|c|c|c|c|c|c|c|}
\hline & & & SHOVEL & & BASAL & & SHOVEL TEST \\
\hline SITE & PROV & TRANSECT & TEST & LEVEL* & DEPTH (cm BS) & NUMBER/TYPE & RESULTS** \\
\hline 38AK287 & 2 & - & .1 & $\mathrm{X}$ & 100 & $.35 x .35 \mathrm{~m}$ Shovel Test & $\mathbf{P}$ \\
\hline 38AK287 & 2 & - & 2 & $\mathbf{x}$ & 100 & $.35 x .35 \mathrm{~m}$ Shovel Test & $\mathbf{P}$ \\
\hline 38AK287 & 2 & - & 3 & $\mathbf{x}$ & 90 & $.35 x .35 \mathrm{~m}$ Shovel Test & $\mathbf{P}$ \\
\hline 38AK287 & 2 & - & 4 & $\mathbf{x}$ & 85 & $.35 \times .35 \mathrm{~m}$ Shovel Test & $\mathbf{N}$ \\
\hline 38AK287 & 2 & - & 5 & $\mathbf{x}$ & 85 & $.35 x .35 \mathrm{~m}$ Shovel Test & $\mathbf{P}$ \\
\hline $38 \mathrm{AK} 287$ & 3 & - & 1 & $\mathbf{x}$ & 105 & $.35 \times .35 \mathrm{~m}$ Shovel Test & $\mathbf{P}$ \\
\hline 38AK287 & 3 & - & 2 & $\mathbf{x}$ & 70 & $.35 x .35 \mathrm{~m}$ Shovel Test & $\mathbf{P}$ \\
\hline $38 \mathrm{AK} 287$ & 3 & - & 3 & $\mathbf{x}$ & 95 & $.35 x .35 \mathrm{~m}$ Shovel Test & $\mathbf{P}$ \\
\hline 38AK287 & 3 & - & 4 & $\mathbf{x}$ & 100 & $.35 x .35 \mathrm{~m}$ Shovel Test & $\mathbf{N}$ \\
\hline 38AK287 & 3 & - & 5 & $\mathbf{x}$ & 95 & $.35 x .35 \mathrm{~m}$ Shovel Test & $\mathbf{P}$ \\
\hline 38AK287 & 3 & - & 6 & $\mathbf{x}$ & 95 & $.35 \times .35 \mathrm{~m}$ Shovel Test & $\mathbf{P}$ \\
\hline 38AK287 & 3 & - & 7 & $\mathbf{x}$ & 95 & $.35 \times .35 \mathrm{~m}$ Shovel Test & $\mathbf{N}$ \\
\hline $38 \mathrm{AK} 287$ & 3 & - & 8 & $\mathbf{x}$ & 90 & $.35 x .35 \mathrm{~m}$ Shovel Test & $\mathbf{P}$ \\
\hline 38AK287 & 3 & - & 9 & $\mathbf{x}$ & 95 & $.35 x .35 \mathrm{~m}$ Shovel Test & $\mathbf{P}$ \\
\hline 38AK287 & 3 & - & 10 & $\mathbf{x}$ & 85 & $.35 x .35 \mathrm{~m}$ Shovel Test & $\mathbf{P}$ \\
\hline 38AK287 & 3 & - & 11 & $\mathrm{x}$ & 95 & $.35 x .35 \mathrm{~m}$ Shovel Test & $\mathbf{N}$ \\
\hline 38AK287 & 3 & - & 12 & $\mathbf{x}$ & 100 & $.35 \times .35 \mathrm{~m}$ Shovel Test & $\mathbf{N}$ \\
\hline 38AK287 & 3 & - & 13 & $\mathbf{x}$ & 100 & $.35 \times .35 \mathrm{~m}$ Shovel Test & $\mathbf{N}$ \\
\hline $38 \mathrm{AK} 287$ & 3 & - & 14 & $\mathrm{x}$ & 95 & $.35 \times .35 \mathrm{~m}$ Shovel Test & $\mathbf{N}$ \\
\hline $38 \mathrm{AK} 287$ & 3 & - & 15 & $\mathrm{x}$ & 90 & $.35 x .35 \mathrm{~m}$ Shovel Test & $\mathbf{P}$ \\
\hline $38 \mathrm{AK} 287$ & 3 & - & 16 & $\mathrm{x}$ & 80 & $.35 \times .35 \mathrm{~m}$ Shovel Test & $\mathbf{P}$ \\
\hline 38AK287 & 3 & - & 17 & $\mathrm{x}$ & 85 & $.35 x .35 \mathrm{~m}$ Shovel Test & $\mathbf{N}$ \\
\hline $38 A K 287$ & 3 & - & 18 & $\mathbf{x}$ & 80 & $.35 x .35 \mathrm{~m}$ Shovel Test & $\mathbf{N}$ \\
\hline 38AK287 & 4 & - & - & A & 10 & 1×2 m; Arbitrary Level & - \\
\hline 38AK287 & 4 & - & - & B & 20 & 1×2 m; Arbitrary Level & - \\
\hline 38AK287 & 4 & - & - & C & 30 & $1 \times 2 \mathrm{~m}$; Arbitrary Level & - \\
\hline $38 \mathrm{AK} 287$ & 4 & - & - & D & 40 & 1×2 m; Arbitrary Level & - \\
\hline 38AK287 & 4 & - & - & E & 50 & 1×2 m; Arbitrary Level & - \\
\hline 38AK287 & 4 & - & - & $\mathrm{F}$ & 60 & 1×2 m; Arbitrary Level & - \\
\hline 38AK287 & 4 & - & - & G & 70 & 1×2 m; Arbitrary Level & - \\
\hline 38AK287 & 4 & - & - & H & 80 & 1×2 m; Arbitrary Level & - \\
\hline $38 \mathrm{AK} 287$ & 4 & - & - & I & 90 & 1×2 m; Arbitrary Level & - \\
\hline $38 \mathrm{AK} 287$ & 4 & - & - & J & 100 & 1×2 m; Arbitrary Level & - \\
\hline 38AK287 & 5 & - & - & A & 10 & $1 \times 2 \mathrm{~m}$; Arbitrary Level & - \\
\hline $38 \mathrm{AK} 287$ & 5 & - & - & B & 20 & $1 \times 2$ m; Arbitrary Level & - \\
\hline $38 \mathrm{AK} 287$ & 6 & - & - & A & 10 & 1 2 m; Arbitrary Level & - \\
\hline 38AK287 & 6 & - & - & B & 20 & $1 \times 2 \mathrm{~m}$; Arbitrary Level & - \\
\hline $38 \mathrm{AK} 287$ & 7 & - & 1 & $x$ & 90 & $.35 \times .35 \mathrm{~m}$ Shovel Test & $\mathbf{N}$ \\
\hline 38AK287 & 7 & - & 2 & $\mathrm{x}$ & 90 & $.35 x .35 \mathrm{~m} \mathrm{Shovel} \mathrm{Test}$ & $\mathbf{N}$ \\
\hline 38AK287 & 7 & - & 3 & $\mathrm{X}$ & 85 & $.35 x .35 \mathrm{~m}$ Shovel Test & $\mathbf{P}$ \\
\hline 38AK287 & 7 & - & 4 & $\mathrm{X}$ & 85 & $.35 x .35 \mathrm{~m}$ Shovel Test & $\mathbf{N}$ \\
\hline 38AK287 & 7 & - & 5 & $\mathrm{X}$ & 85 & $.35 x .35 \mathrm{~m}$ Shovel Test & $\mathbf{N}$ \\
\hline 38AK287 & 7 & - & 6 & $\mathrm{x}$ & 85 & $.35 x .35 \mathrm{~m}$ Shovel Test & $\mathbf{P}$ \\
\hline $38 \mathrm{AK} 287$ & 7 & - & 7 & $\mathbf{X}$ & 90 & $.35 x .35 \mathrm{~m}$ Shovel Test & $\mathbf{N}$ \\
\hline
\end{tabular}


Appendix A. (continued).

SHOVEL

BASAL

\begin{tabular}{|c|c|c|c|c|c|c|c|}
\hline & & & DHUVEL & & BASAL & & HUVEL IESI \\
\hline SITE & PROV & TRANSECT & TEST & LEVEL* & DEPTH (cm BS) & NUMBER/TYPE & RESULTS** \\
\hline 38AK287 & 8 & - & 1 & $X$ & 85 & $.35 \times .35 \mathrm{~m}$ Shovel Test & $\mathbf{N}$ \\
\hline 38 AK287 & 8 & - & 2 & $\mathbf{X}$ & 85 & $.35 x .35 \mathrm{~m}$ Shovel Test & $\mathbf{N}$ \\
\hline 38 AK287 & 8 & - & 3 & $\mathbf{X}$ & 85 & $.35 x .35 \mathrm{~m}$ Shovel Test & $\mathbf{P}$ \\
\hline 38AK287 & 8 & - & 4 & $\mathbf{x}$ & 95 & $.35 x .35 \mathrm{~m}$ Shovel Test & $\mathbf{P}$ \\
\hline 38AK287 & 8 & - & 5 & $\mathbf{X}$ & 85 & $.35 x .35 \mathrm{~m}$ Shovel Test & $\mathbf{N}$ \\
\hline 38AK287 & 8 & - & 6 & $\mathbf{x}$ & 95 & $.35 x .35 \mathrm{~m}$ Shovel Test & $\mathbf{P}$ \\
\hline 38AK287 & 8 & - & 7 & $\mathbf{X}$ & 80 & $.35 \times .35 \mathrm{~m}$ Shovel Test & $\mathbf{P}$ \\
\hline 38 AK287 & 8 & - & 8 & $\mathbf{X}$ & 90 & $.35 \times .35 \mathrm{~m}$ Shovel Test & $\mathbf{P}$ \\
\hline $38 \mathrm{AK} 287$ & 8 & - & 9 & $\mathbf{X}$ & 105 & $.35 \times .35 \mathrm{~m}$ Shovel Test & $\mathbf{P}$ \\
\hline 38AK288 & 11 & - & 1 & $\mathbf{X}$ & 90 & $.35 x .35 \mathrm{~m}$ Shovel Test & $\mathbf{P}$ \\
\hline 38AK288 & 11 & - & 2 & $\mathbf{X}$ & 85 & $.35 x .35 \mathrm{~m}$ Shovel Test & $\mathbf{P}$ \\
\hline 38AK288 & 11 & - & 3 & $\mathbf{x}$ & 85 & $.35 \times .35 \mathrm{~m}$ Shovel Test & $\mathbf{P}$ \\
\hline 38 AK288 & 11 & - & 4 & $\mathbf{X}$ & 85 & $.35 x .35 \mathrm{~m}$ Shovel Test & $\mathbf{N}$ \\
\hline $38 \mathrm{AK} 288$ & 11 & - & 5 & $\mathbf{X}$ & 85 & $.35 x .35 \mathrm{~m}$ Shovel Test & $\mathbf{N}$ \\
\hline 38AK289 & 3 & - & - & $\mathbf{A}$ & 10 & $1 \times 2 \mathrm{~m}$; Arbitrary Level & - \\
\hline 38AK289 & 3 & - & - & $\mathbf{B}$ & 21 & 1×2 m; Artitrary Level & - \\
\hline 38AK289 & 3 & - & - & $\mathrm{C}$ & 30 & $1 \times 2 \mathrm{~m}$; Arbitrary Level & - \\
\hline 38AK289 & 3 & - & - & D & 41 & 1×2 m; Arbitrary Leyel & - \\
\hline 38AK289 & 3 & - & - & $\mathbf{E}$ & 50 & 1×2 m; Arbitrary Level & - \\
\hline 38 AK289 & 3 & - & - & $\mathbf{F}$ & 61 & $1 \times 2 \mathrm{~m}$; Arbitrary Level & - \\
\hline $38 A K 289$ & 3 & - & - & G & 70 & 1×2 m; Arbitrary Lovel & - \\
\hline 38 AK289 & 3 & - & - & H & 80 & 1×2 m; Arbitrary Level & - \\
\hline 38AK289 & 3 & - & - & I & 91 & $1 \times 2 \mathrm{~m}$; Arbitrary Level & - \\
\hline 38AK289 & 3 & - & - & J & 100 & $1 \times 2 \mathrm{~m}$; Arbitrary Lovel & - \\
\hline 38AK289 & 4 & - & - & A & 10 & 1×2 m; Arbitrary Level & - \\
\hline 38AK289 & 4 & - & - & $\mathbf{B}$ & 20 & $1 \times 2 \mathrm{~m}$; Arbitrary Level & - \\
\hline 38AK289 & 4 & - & - & $\mathrm{C}$ & 22 & $1 \times 2 \mathrm{~m}$; Arbitrary Level & - \\
\hline 38AK289 & 4 & - & - & D & 32 & $1 \times 2 \mathrm{~m}$; Arbitrary Level & - \\
\hline 38AK289 & 4 & - & - & $\mathrm{E}$ & 42 & $1 \times 2 \mathrm{~m}$; Arbitrary Level & - \\
\hline 38AK289 & 4 & - & - & $\mathbf{F}$ & 52 & 1×2 m; Arbitrary Level & - \\
\hline $38 \mathrm{AK} 289$ & 4 & - & - & G & 62 & $1 \times 2 \mathrm{~m}$; Arbitrary Level & - \\
\hline $38 \mathrm{AK} 289$ & 4 & - & - & $\mathbf{H}$ & 72 & $1 \times 2 \mathrm{~m}$; Arbitrary Level & - \\
\hline 38AK289 & 4 & - & - & I & 83 & $1 \times 2 \mathrm{~m}$; Arbitrary Level & - \\
\hline 38 AK289 & 4 & - & - & $\mathbf{J}$ & 92 & 1×2 m; Arbitrary Level & - \\
\hline $38 \mathrm{AK} 289$ & 4 & - & - & $K$ & 102 & 1×2 m; Arbitrary Level & - \\
\hline 38AK289 & 4 & - & - & $\mathbf{L}$ & 112 & $1 \times 2 \mathrm{~m}$; Arbitrary Level & - \\
\hline 38AK289 & 4 & - & - & $\mathbf{M}$ & 122 & $1 \times 2 \mathrm{~m}$; Arbitrary Level & - \\
\hline 38AK289 & 5 & - & - & $A$ & 10 & $1 \times 2 \mathrm{~m}$; Arbitrary Level & - \\
\hline 38AK289 & 5 & - & - & B & 20 & 1×2 m; Arbitrary Level & - \\
\hline 38AK289 & 5 & - & - & $\mathrm{C}$ & 30 & $1 \times 2 \mathrm{~m}$; Arbitrary Level & - \\
\hline 38AK289 & 5 & - & - & D & 40 & 1×2 m; Arbitrary Level & - \\
\hline 38AK289 & 5 & - & - & $\mathrm{E}$ & 50 & $1 \times 2 \mathrm{~m}$; Arbitrary Level & - \\
\hline
\end{tabular}


Appendix A. (continued).

\begin{tabular}{|c|c|c|c|c|c|c|c|}
\hline & & & SHOVEL & & BASAL & & SHOVEL TEST \\
\hline SITE & PROV & TRANSECT & TEST & LEVEL* & DEPTH (cm BS) & NUMBER/TYPE & RESULTS** \\
\hline 38AK289 & 5 & - & - & $\mathbf{F}$ & 60 & 1×2 m; Arbitrary Level & - \\
\hline 38AK289 & 5 & - & - & $\mathbf{G}$ & 70 & $1 \times 2$ m; Arbitrary Level & - \\
\hline 38 AK289 & 5 & - & - & $\mathbf{H}$ & 80 & $1 \times 2 \mathrm{~m}$; Arbitrary Level & - \\
\hline 38 AK289 & 5 & - & - & I & 90 & $1 \times 2 \mathrm{~m}$; Arbitrary Level & - \\
\hline 38AK289 & $\mathbf{s}$ & - & - & $J$ & 100 & $1 \times 2 \mathrm{~m}$; Arbitrary Level & - \\
\hline 38AK289 & 5 & - & - & $\mathbf{K}$ & 110 & l×2 m; Arbitrary Level & - \\
\hline 38AK289 & 5 & - & - & $\mathbf{L}$ & 120 & I×2 m; Arbitrary Level & - \\
\hline 38AK289 & 5 & - & - & $\mathbf{M}$ & 130 & 1×2 m; Arbitrary Level & - \\
\hline 38AK289 & 6 & - & - & $\mathbf{A}$ & 10 & 1×2 m; Artitrary Level & - \\
\hline 38AK289 & 6 & - & - & $\mathbf{B}$ & 20 & 1×2 m; Arbitrary Level & - \\
\hline $38 \mathrm{AK} 289$ & 6 & - & - & C & 30 & 1×2 m; Arbitrary Level & - \\
\hline 38AK289 & 6 & - & - & D & 40 & $1 \times 2 \mathrm{~m}$; Arbitrary Level & - \\
\hline 38AK289 & 6 & - & - & $\mathbf{E}$ & 50 & 1×2 m; Arbitrary Level & - \\
\hline 38 AK289 & 6 & - & - & $\mathbf{F}$ & 60 & 1 $\times 2 \mathrm{~m}$; Artitrary Level & - \\
\hline 38AK289 & 6 & - & - & $\mathbf{G}$ & 70 & $1 \times 2 \mathrm{~m}$; Arbitrary Level & - \\
\hline 38AK289 & 6 & - & - & $\mathbf{H}$ & 80 & $1 \times 2 \mathrm{~m}$; Arbitrary Level & - \\
\hline 38AK289 & 6 & - & - & 1 & 90 & 1×2 m; Arbitrary Level & - \\
\hline 38 AK289 & 6 & - & - & $\mathbf{J}$ & 100 & $1 \times 2 \mathrm{~m}$; Arbitrary Level & - \\
\hline 38AK289 & 6 & - & - & $\mathbf{K}$ & 110 & 1×2 m; Arbitrary Level & - \\
\hline 38 AK289 & 7 & - & - & $\mathbf{A}$ & 10 & 1 $x 1 \mathrm{~m}$; Arbitrary Level & - \\
\hline 38AK289 & 7 & - & - & B & 20 & lxl m; Arbitrary Level & - \\
\hline $38 \mathrm{AK} 289$ & 7 & - & - & C & 30 & Ixl m; Arbitrary Level & - \\
\hline 38AK289 & 7 & - & - & D & 40 & Ixl m; Arbitrary Level & - \\
\hline 38AK289 & 8 & - & - & $\mathbf{A}$ & 10 & Ix1 m; Arbitrary Level & - \\
\hline 38AK289 & 8 & - & - & B & 20 & 1x1 m; Artitrary Level & - \\
\hline $38 \mathrm{AK} 289$ & 8 & - & - & C & 30 & $1 \times 1 \mathrm{~m}$; Arbitrary Level & - \\
\hline 38AK289 & 9 & - & - & $\mathbf{A}$ & 10 & lxı m; Arbitrary Level & - \\
\hline $38 \mathrm{AK} 289$ & 9 & - & - & $\mathbf{B}$ & 20 & $1 \mathrm{x} 1 \mathrm{~m}$; Arbitrary Level & - \\
\hline 38AK289 & 9 & - & - & $\mathrm{C}$ & 35 & IxI m; Arbitrary Level & - \\
\hline $38 \mathrm{AK} 289$ & 10 & - & - & A & 10 & IxI m; Arbitrary Level & - \\
\hline 38AK289 & 10 & - & - & $\mathbf{B}$ & 20 & IxI m; Arbitrary Level & - \\
\hline 38AK289 & 11 & - & - & $A$ & 10 & $1 \times 1 \mathrm{~m} ;$ Arbitrary Level & - \\
\hline 38AK289 & 11 & - & - & B & 20 & Ixl m; Artitra, Level & - \\
\hline 38AK289 & 12 & - & - & $\mathbf{A}$ & 10 & $2 \times 2 \mathrm{~m}$; Arbitrary Level & - \\
\hline 38AK289 & 12 & - & - & $\mathbf{B}$ & 20 & $2 \times 2 \mathrm{~m} ;$ Arbitrary Level & - \\
\hline $38 \mathrm{AK} 289$ & 12 & - & - & $\mathrm{C}$ & 30 & $2 \times 2 \mathrm{~m}$; Arbitrary Level & - \\
\hline 38 AK289 & 12 & - & - & D & 40 & $2 \times 2 \mathrm{~m}$; Arbitrary Level & - \\
\hline $38 \mathrm{AK} 289$ & 12 & - & - & $\mathrm{E}$ & 50 & $2 \times 2 \mathrm{~m}$; Arbitrary Level & - \\
\hline 38AK289 & 12 & - & - & $\mathbf{F}$ & 60 & $2 \times 2 \mathrm{~m}$; Arbitrary Level & - \\
\hline 38AK289 & 12 & - & - & G & 70 & $2 \times 2 \mathrm{~m}$; Arbitrary Level & - \\
\hline 38AK289 & 12 & - & - & $\mathbf{H}$ & 80 & $2 \times 2 \mathrm{~m}$; Artitrary Level & - \\
\hline 38 AK289 & 12 & - & - & 1 & 90 & $2 \times 2 \mathrm{~m}$; Arbitrary Level & - \\
\hline 38AK289 & 12 & - & - & $J$ & 100 & $2 \times 2 \mathrm{~m}$; Arbitrary Level & - \\
\hline $38 \mathrm{AK} 289$ & 12 & - & - & $\mathbf{K}$ & 110 & $2 \times 2 \mathrm{~m}$; Arbitrary Level & - \\
\hline
\end{tabular}


Appendix A. (continued).

\begin{tabular}{|c|c|c|c|c|c|c|c|}
\hline & & & SHOVEL & & BASAL & & $\begin{array}{l}\text { SHOVEL TEST } \\
\text { RESULTS*** }\end{array}$ \\
\hline SITE & PROV & TRANSECT & TEST & LEVEL* & & NUMBER/YYPE & \\
\hline 38AK289 & 12 & - & - & L & 120 & $2 \times 2 \mathrm{~m}$; Arbitrary Lovel & - \\
\hline 38AK289 & 12 & - & - & $\mathbf{M}$ & 130 & $2 \times 2 \mathrm{~m}$; Arbitrary Level & - \\
\hline 38AK289 & 13 & 1 & 1 & $\mathbf{x}$ & 85 & $.35 x .35 \mathrm{~m}$ Shovel Test & $\mathbf{N}$ \\
\hline 38AK289 & 13 & 1 & 2 & $\mathbf{x}$ & 100 & $.35 x .35 \mathrm{~m}$ Shovel Test & $\mathbf{P}$ \\
\hline 38AK289 & 13 & 1 & 3 & $\mathbf{x}$ & 100 & $.35 x .35 \mathrm{~m}$ Shovel Test & $\mathbf{P}$ \\
\hline 38AK289 & 13 & 1 & 4 & $\mathbf{x}$ & 100 & $.35 x .35 \mathrm{~m}$ Shovel Test & $\mathbf{P}$ \\
\hline 38AK289 & 13 & 1 & 5 & $\mathbf{x}$ & 100 & $.35 \times .35 \mathrm{~m}$ Shovel Test & $\mathbf{P}$ \\
\hline 38AK289 & 13 & 1 & 6 & $\mathbf{x}$ & 90 & $.35 x .35 \mathrm{~m}$ Shovel Test & $\mathbf{P}$ \\
\hline 38AK289 & 13 & 1 & 7 & $\mathbf{x}$ & 95 & $.35 \times .35 \mathrm{~m}$ Shovel Test & $\mathbf{P}$ \\
\hline 38AK289 & 13 & 1 & 8 & $\mathbf{x}$ & 85 & $.35 x .35 \mathrm{~m}$ Shovel Test & $\mathbf{P}$ \\
\hline 38AK289 & 13 & 1 & 9 & $\mathbf{x}$ & 100 & $.35 x .35 \mathrm{~m}$ Shovel Test & $\mathbf{P}$ \\
\hline 38AK289 & 13 & 1 & 10 & $\mathbf{x}$ & 85 & $.35 x .35 \mathrm{~m}$ Shovel Test & $\mathbf{P}$ \\
\hline 38AK289 & 13 & 1 & 11 & $\mathbf{x}$ & 55 & $.35 x .35 \mathrm{~m}$ Shovel Test & $\mathbf{N}$ \\
\hline 38AK289 & 13 & 1 & 12 & $\mathbf{x}$ & 30 & $.35 \times .35 \mathrm{~m}$ Shovel Test & $\mathbf{N}$ \\
\hline 38AK289 & 13 & 2 & 1 & $\mathbf{x}$ & 100 & $.35 \times .35 \mathrm{~m}$ Shovel Test & $\mathbf{P}$ \\
\hline 38AK289 & 13 & 2 & 2 & $\mathbf{x}$ & 90 & $.35 \times .35 \mathrm{~m}$ Shovel Test & $\mathbf{P}$ \\
\hline 38 AK289 & 13 & 2 & 3 & $\mathbf{x}$ & 90 & $.35 \times .35 \mathrm{~m}$ Shovel Te:t & $\mathbf{P}$ \\
\hline 38AK289 & 13 & 2 & 4 & $\mathbf{x}$ & 100 & $.35 x .35 \mathrm{~m}$ Shovel Test & $\mathbf{P}$ \\
\hline 38AK289 & 13 & 2 & 5 & $\mathbf{x}$ & 80 & $.35 x .35 \mathrm{~m}$ Shovel Test & $\mathbf{P}$ \\
\hline 38AK289 & 13 & 2 & 6 & $\mathbf{x}$ & 95 & $.35 x .35 \mathrm{~m}$ Shovel Test & $\mathbf{P}$ \\
\hline 38AK289 & 13 & 2 & 7 & $\mathbf{x}$ & 90 & $.35 x .35 \mathrm{~m}$ Shovel Test & $\mathbf{N}$ \\
\hline 38AK289 & 13 & 2 & 8 & $\mathbf{x}$ & 85 & $.35 x .35 \mathrm{~m}$ Shovel Test & $\mathbf{N}$ \\
\hline 38AK289 & 13 & 2 & 9 & $\mathbf{x}$ & 55 & $.35 x .35 \mathrm{~m}$ Shovel Test & $\mathbf{N}$ \\
\hline 38AK289 & 13 & 3 & 1 & $\mathbf{x}$ & 80 & $.35 x .35 \mathrm{~m}$ Shovel Test & $\mathbf{N}$ \\
\hline 38AK289 & 13 & 3 & 2 & $x$ & 100 & $.35 \times .35 \mathrm{~m}$ Shovel Test & $\mathbf{P}$ \\
\hline 38AK289 & 13 & 3 & 3 & $\mathbf{x}$ & 90 & $.35 \times .35 \mathrm{~m}$ Shovel Test & $\mathbf{P}$ \\
\hline 38AK289 & 13 & 3 & 4 & $\mathbf{x}$ & 100 & $.35 \times .35 \mathrm{~m}$ Shovel Test & $\mathbf{P}$ \\
\hline 38AK289 & 13 & 3 & 5 & $\mathbf{x}$ & 100 & $.35 x .35 \mathrm{~m}$ Shovel Test & $\mathbf{P}$ \\
\hline 38AK289 & 13 & 3 & 6 & $\mathbf{x}$ & 100 & $.35 x .35 \mathrm{~m}$ Shovel Test & $\mathbf{P}$ \\
\hline 38AK289 & 13 & 3 & 7 & $\mathbf{x}$ & 100 & $.35 x .35 \mathrm{~m}$ Shovel Test & $\mathbf{P}$ \\
\hline 38AK289 & 13 & 3 & 8 & $\mathbf{x}$ & 90 & $.35 x .35 \mathrm{~m}$ Shovel Test & $\mathbf{P}$ \\
\hline 38AK289 & 13 & 3 & 9 & $\mathbf{x}$ & 100 & $.35 \times .35 \mathrm{~m}$ Shovel Test & $\mathbf{P}$ \\
\hline 38AK289 & 13 & j & 10 & $\mathbf{x}$ & 95 & $.35 x .35 \mathrm{~m}$ Shovel Test & $\mathbf{N}$ \\
\hline 38AK289 & 13 & 3 & 11 & $\boldsymbol{x}$ & 95 & $.35 \times .35 \mathrm{~m}$ Shovel Test & $\mathbf{N}$ \\
\hline $38 \mathrm{AK} 289$ & 13 & 3 & 12 & $\mathbf{x}$ & 40 & $.35 x .35 \mathrm{~m}$ Shovel Test & $\mathbf{N}$ \\
\hline 38 AK289 & 13 & 3 & 13 & $\mathbf{x}$ & 90 & $.35 \times .35 \mathrm{~m}$ Shovel Test & $\mathbf{P}$ \\
\hline 38AK289 & 13 & 3 & 14 & $\mathbf{x}$ & 70 & $.35 x .35 \mathrm{~m}$ Shovel Test & $\mathbf{P}$ \\
\hline 38AK289 & 13 & 4 & 1 & $\mathbf{x}$ & 95 & $.35 \times .35 \mathrm{~m}$ Shovel Test & $\mathbf{N}$ \\
\hline 38AK289 & 13 & 4 & 2 & $\mathrm{x}$ & 105 & $.35 \times .35 \mathrm{~m}$ Shovel Test & $\mathbf{P}$ \\
\hline 38AK289 & 13 & 4 & 3 & $\mathbf{x}$ & 100 & $.35 x .35 \mathrm{~m}$ Shovel Test & $\mathbf{P}$ \\
\hline 38AK289 & 13 & 4 & 4 & $\mathbf{X}$ & 95 & $.35 x .35 \mathrm{~m}$ Shovel Test & $\mathbf{P}$ \\
\hline 38AK289 & 13 & 4 & 5 & $x$ & 80 & $.35 x .35 \mathrm{~m}$ Shovel Test & $\mathbf{P}$ \\
\hline 38AK289 & 13 & 4 & 6 & $\mathbf{x}$ & 90 & $.35 x .35 \mathrm{~m}$ Shovel Test & $\mathbf{P}$ \\
\hline 38 AK289 & 13 & 4 & 7 & $\mathbf{x}$ & 80 & $.35 x .35 \mathrm{~m}$ Shovel Test & $\mathbf{N}$ \\
\hline
\end{tabular}


Appendix A. (continued).

SHOVEL

BASAL

\begin{tabular}{|c|c|c|c|c|c|c|c|}
\hline & & & SHOVE & & BASAL & & SHOVEL TEST \\
\hline SITE & PROV & TRANSECT & TEST & LEVEL* & DEPTH $(\mathrm{cm}$ BS $)$ & NUMBER/TYPE & RESULTS** \\
\hline 38AK289 & 13 & 4 & 8 & $\mathbf{x}$ & 90 & $.35 x .35 \mathrm{~m}$ Shovel Test & $\mathbf{N}$ \\
\hline 38AK289 & 13 & 4 & 9 & $\mathbf{X}$ & 100 & $.35 x .35 \mathrm{~m}$ Shovel Test & $\mathbf{P}$ \\
\hline 38AK289 & 13 & 4 & 10 & $\mathbf{X}$ & 100 & $.35 x .35 \mathrm{~m}$ Shovel Test & $\mathbf{P}$ \\
\hline 38AK289 & 13 & 4 & 11 & $\mathbf{X}$ & 90 & $.35 x .35 \mathrm{~m}$ Shovel Test & $\mathbf{P}$ \\
\hline 38AK289 & 13 & 4 & 12 & $\mathbf{x}$ & 80 & $.35 x .35 \mathrm{~m}$ Shovel Test & $\mathbf{P}$ \\
\hline $38 A K 289$ & 13 & 4 & 13 & $\mathbf{X}$ & 40 & $.35 x .35 \mathrm{~m}$ Shovel Test & $\mathbf{P}$ \\
\hline 38AK289 & 13 & 4 & 14 & $\mathbf{x}$ & 85 & $.35 \times .35 \mathrm{~m}$ Shovel Test & $\mathbf{P}$ \\
\hline 38AK289 & 13 & 4 & 15 & $\mathbf{X}$ & 105 & $.35 \times .35 \mathrm{~m}$ Shovel Test & $\mathbf{P}$ \\
\hline $38 A K 289$ & 13 & 5 & 1 & $\mathbf{X}$ & 90 & $.35 x .35 \mathrm{~m}$ Shovel Test & $\mathbf{N}$ \\
\hline 38AK289 & 13 & 5 & 2 & $\mathbf{X}$ & 85 & $.35 \times .35 \mathrm{~m}$ Shovel Test & $\mathbf{N}$ \\
\hline 38AK289 & 13 & 5 & 3 & $\mathbf{x}$ & 90 & $.35 x .35 \mathrm{~m}$ Shovel Test & $\mathbf{P}$ \\
\hline 38AK289 & 13 & 5 & 4 & $\mathbf{X}$ & 80 & $.35 x .35 \mathrm{~m}$ Shovel Test & $\mathbf{P}$ \\
\hline 38AK289 & 13 & 5 & 5 & $\mathbf{X}$ & 75 & $.35 \times .35 \mathrm{~m}$ Shovel Test & $\mathbf{N}$ \\
\hline 38AK289 & 13 & 5 & 6 & $\mathbf{X}$ & 95 & $.35 \times .35 \mathrm{~m}$ Shovel Test & $\mathbf{N}$ \\
\hline 38AK289 & 13 & 5 & 7 & $\mathbf{x}$ & 80 & $.35 \times .35 \mathrm{~m}$ Shovel Test & $\mathbf{N}$ \\
\hline 38AK289 & 13 & 5 & 8 & $\mathbf{X}$ & 95 & $.35 \times .35 \mathrm{~m}$ Shovel Test & $\mathbf{P}$ \\
\hline 38AK289 & 13 & 5 & 9 & $\mathbf{X}$ & 90 & $.35 \times .35 \mathrm{~m}$ Shovel Test & $\mathbf{P}$ \\
\hline $38 A K 289$ & 13 & 5 & 10 & $\mathbf{X}$ & 90 & $.35 \times .35 \mathrm{~m}$ Shovel Test & $\mathbf{N}$ \\
\hline 38AK289 & 13 & 5 & 11 & $\mathbf{X}$ & 90 & $.35 \times .35 \mathrm{~m}$ Shovel Test & $\mathbf{N}$ \\
\hline $38 \mathrm{AK} 289$ & 13 & 5 & 12 & $\mathbf{x}$ & 90 & $.35 \times .35 \mathrm{~m}$ Shovel Test & $\mathbf{P}$ \\
\hline 38AK289 & 13 & 5 & 13 & $\mathbf{X}$ & 90 & $.35 \times .35 \mathrm{~m}$ Shovel Test & $\mathbf{N}$ \\
\hline 38AK289 & 13 & 6 & 1 & $\mathbf{X}$ & 90 & $.35 \times .35 \mathrm{~m}$ Shovel Test & $\mathbf{P}$ \\
\hline 38AK289 & 13 & 6 & 2 & $\mathbf{X}$ & 80 & $.35 \times .35 \mathrm{~m}$ Shovel Test & $\mathbf{P}$ \\
\hline $38.1 K 289$ & 13 & 6 & 3 & $\mathbf{X}$ & 95 & $.35 x .35 \mathrm{~m}$ Shovel Test & $\mathbf{P}$ \\
\hline 38AK289 & 13 & 6 & 4 & $\mathbf{X}$ & 90 & $.35 \times .35 \mathrm{~m}$ Shovel Test & $\mathbf{P}$ \\
\hline 38AK289 & 13 & 6 & 5 & $\mathbf{X}$ & 90 & $.35 \times .35 \mathrm{~m}$ Shovel Test & $\mathbf{N}$ \\
\hline 38AK289 & 13 & 6 & 6 & $\mathbf{X}$ & 90 & $.35 x .35 \mathrm{~m}$ Shovel Test & $\mathbf{P}$ \\
\hline 38AK289 & 13 & 6 & 7 & $\mathbf{X}$ & 85 & $.35 \times .35 \mathrm{~m}$ Shovel Test & $\mathbf{P}$ \\
\hline 38AK289 & 13 & 6 & 8 & $\mathbf{X}$ & 80 & $.35 \times .35 \mathrm{~m}$ Shovel Test & $\mathbf{N}$ \\
\hline 38AK289 & 13 & 6 & 9 & $\mathbf{X}$ & 90 & $.35 \times .35 \mathrm{~m}$ Shovel Test & $\mathbf{N}$ \\
\hline 38AK289 & 13 & 6 & 10 & $\mathbf{X}$ & 90 & $.35 \times .35 \mathrm{~m}$ Shovel Test & $\mathbf{P}$ \\
\hline 38 AK289 & 13 & 6 & 11 & $\mathbf{X}$ & 95 & $.35 \times .35 \mathrm{~m}$ Shovel Test & $\mathbf{N}$ \\
\hline 38AK289 & 13 & 6 & 12 & $x$ & 80 & $.35 \times .35 \mathrm{~m}$ Shovel Test & $\mathbf{P}$ \\
\hline- & 13 & 6 & 13 & $\mathbf{X}$ & 75 & $.35 \times .35 \mathrm{~m}$ Shovel Test & $\mathbf{N}$ \\
\hline 38AK289 & 13 & 6 & 14 & $\mathbf{X}$ & 85 & $.35 \times .35 \mathrm{~m}$ Shovel Test & $\mathbf{N}$ \\
\hline 38AK289 & 13 & 6 & 15 & $\mathbf{X}$ & 80 & $.35 \times .35 \mathrm{~m}$ Shovel Test & $\mathbf{P}$ \\
\hline 38AK289 & 13 & 7 & 1 & $X$ & 90 & $.35 \times .35 \mathrm{~m}$ Shovel Test & $\mathbf{P}$ \\
\hline 38AK289 & 13 & 7 & 2 & $\mathbf{X}$ & 90 & $.35 \times .35 \mathrm{~m}$ Shovel Test & $\mathbf{P}$ \\
\hline 38 AK289 & 13 & 7 & 3 & $X$ & 95 & $.35 \times .35 \mathrm{~m}$ Shovel Test & $\mathbf{N}$ \\
\hline 38AK289 & 13 & 7 & 4 & $\mathrm{X}$ & 95 & $.35 \times .35 \mathrm{~m}$ Shovel Test & $\mathbf{P}$ \\
\hline 38AK289 & 13 & 7 & 5 & $\mathbf{X}$ & 95 & $.35 \times .35 \mathrm{~m}$ Shovel Test & $\mathbf{N}$ \\
\hline 38 AK289 & 13 & 7 & 6 & $\mathbf{X}$ & 85 & $.35 \times .35 \mathrm{~m}$ Shovel Test & $\mathbf{P}$ \\
\hline 38AK289 & 13 & 7 & 7 & $\mathbf{X}$ & 90 & $.35 \times .35 \mathrm{~m}$ Shovel Test & $\mathbf{P}$ \\
\hline 38AK289 & 13 & 7 & 8 & $\mathbf{X}$ & 70 & $.35 \times .35 \mathrm{~m}$ Shovel Test & $\mathbf{N}$ \\
\hline
\end{tabular}



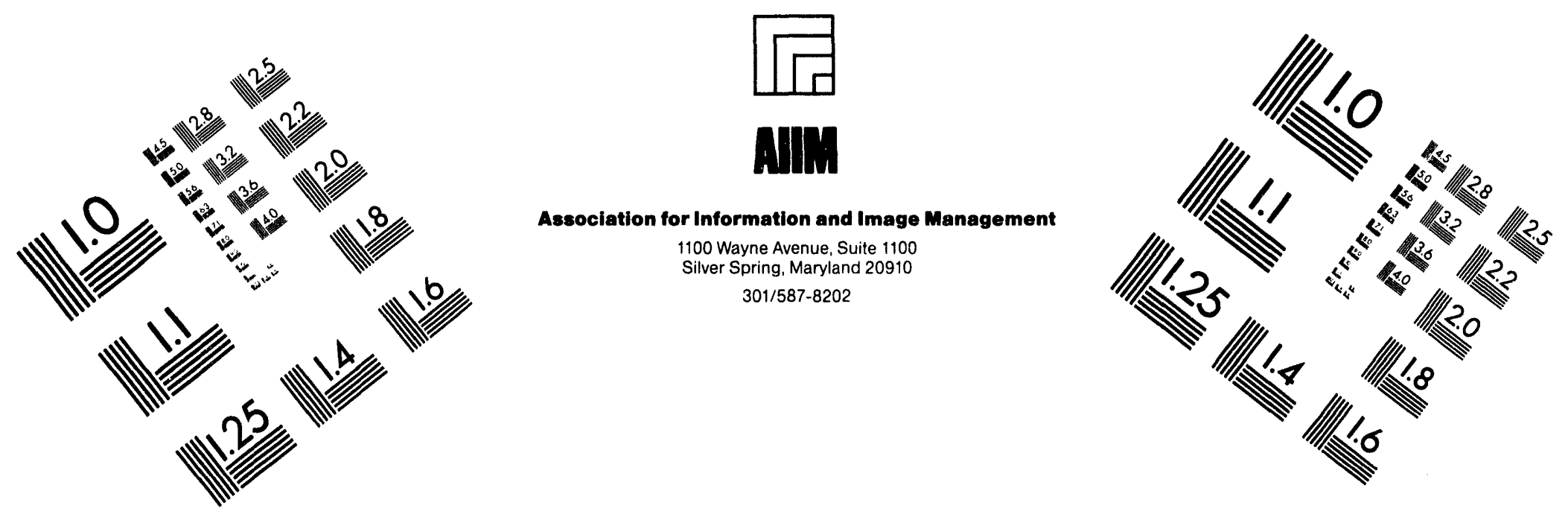

\section{Centimeter}

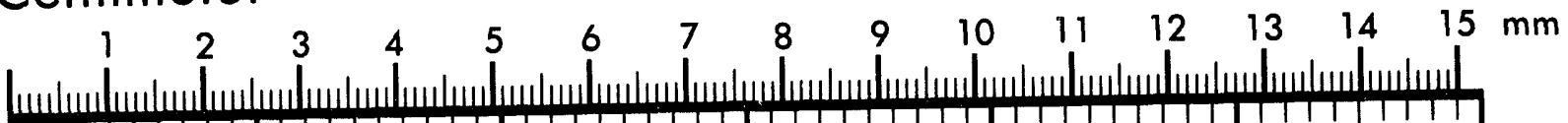

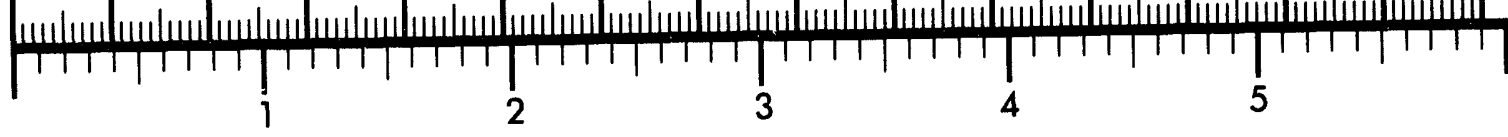
Inches
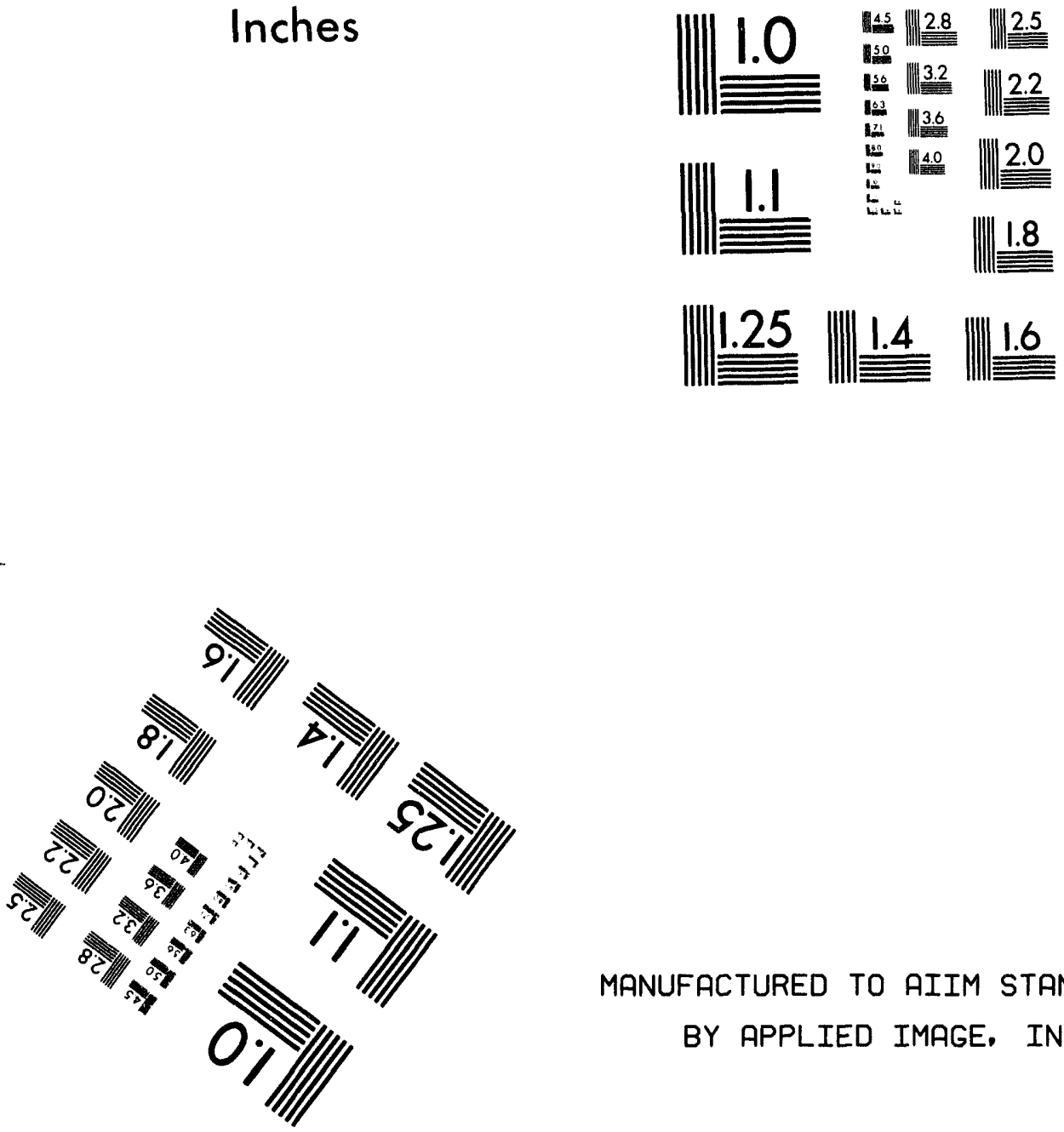

MANUFACTURED TO AIIM STANDARDS

$$
\text { BY APPLIED IMAGE. INC. }
$$

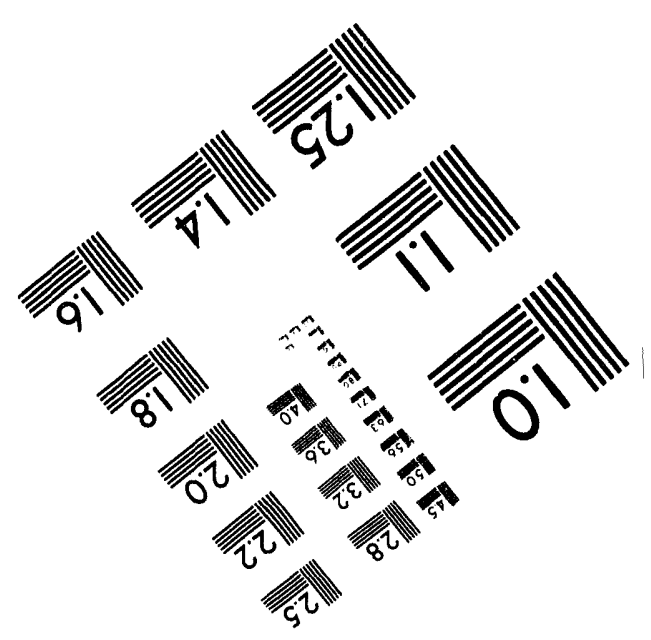



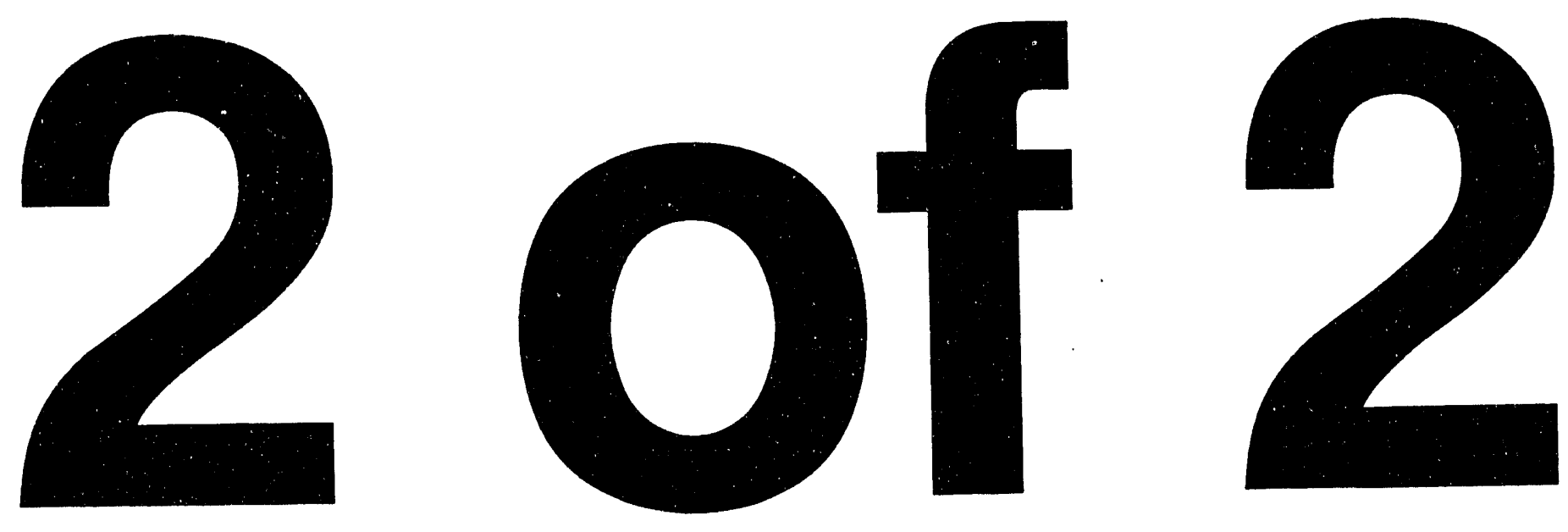
Appendix A. (continued).

SHOVEL

BASAL

SHOVEL TEST

\begin{tabular}{|c|c|c|c|c|c|c|c|}
\hline SITE & PROV & TRANSECT & TEST & LEVEL* & DEPTH (cm BS) & NUMBER/TYPE & RESULTS** \\
\hline $38 \mathrm{AK} 289$ & 13 & 7 & 9 & $\mathbf{X}$ & 100 & $.35 x .35 \mathrm{~m}$ Shovel Test & $\mathbf{P}$ \\
\hline 38AK289 & 13 & 7 & 10 & $\mathbf{X}$ & 85 & $.35 \times .35 \mathrm{~m}$ Shovel Test & $\mathbf{N}$ \\
\hline 38 AK289 & 13 & 7 & 11 & $\mathbf{X}$ & 80 & $.35 x .35 \mathrm{~m}$ Shovel Test & $\mathbf{P}$ \\
\hline 38AK289 & 13 & 7 & 12 & $\mathbf{x}$ & 95 & $.35 \times .35 \mathrm{~m}$ Shovel Test & $\mathbf{N}$ \\
\hline 38AK289 & 13 & 7 & 13 & $\mathbf{X}$ & 95 & $.35 x .35 \mathrm{~m}$ Shovel Test & $\mathbf{N}$ \\
\hline 38AK289 & 13 & 8 & 1 & $\mathbf{X}$ & 95 & $.35 \times .35 \mathrm{~m}$ Shovel Test & $\mathbf{P}$ \\
\hline 38AK289 & 13 & 8 & 2 & $\mathbf{X}$ & 85 & $.35 \times .35 \mathrm{~m}$ Shovel Test & $\mathbf{P}$ \\
\hline 38AK289 & 13 & 8 & 3 & $\mathbf{x}$ & 80 & $.35 \times .35 \mathrm{~m}$ Shovel Test & $\mathbf{N}$ \\
\hline $38 \mathrm{AK} 289$ & 13 & 8 & 4 & $\mathbf{X}$ & 85 & $.35 x .35 \mathrm{~m}$ Shovel Test & $\mathbf{N}$ \\
\hline 38 AK289 & 13 & 8 & 5 & $\mathbf{x}$ & 85 & $.35 x .35 \mathrm{~m}$ Shovel Test & $\mathbf{P}$ \\
\hline 38AK289 & 13 & 8 & 6 & $\mathbf{X}$ & 95 & $.35 x .35 \mathrm{~m}$ Shovel Test & $\mathbf{N}$ \\
\hline $38 \mathrm{AK} 289$ & 13 & 8 & 7 & $\mathbf{x}$ & 75 & $.35 x .35 \mathrm{~m}$ Shovel Test & $\mathbf{P}$ \\
\hline 38AK289 & 13 & 8 & 8 & $\mathbf{x}$ & 85 & $.35 x .35 \mathrm{~m}$ Shovel Test & $\mathbf{N}$ \\
\hline 38AK289 & 13 & 8 & 9 & $\mathbf{x}$ & 80 & $.35 x .35 \mathrm{~m}$ Shovel Test & $\mathbf{P}$ \\
\hline 38AK289 & 13 & 8 & 10 & $\mathbf{X}$ & 90 & $.35 \times .35 \mathrm{~m}$ Shovel Test & $\mathbf{N}$ \\
\hline 38AK289 & 13 & 8 & 11 & $\mathbf{x}$ & 75 & $.35 x .35 \mathrm{~m}$ Shovel Test & $\mathbf{p}$ \\
\hline- & 13 & 8 & 12 & $\mathbf{X}$ & 85 & $.35 \times .35 \mathrm{~m}$ Shovel Test & $\mathbf{N}$ \\
\hline $38 \mathrm{AK} 289$ & 13 & 8 & 13 & $\mathbf{X}$ & 85 & $.35 x .35 \mathrm{~m}$ Shovel Test & $\mathbf{N}$ \\
\hline 38 AK289 & 13 & 8 & 14 & $\mathbf{X}$ & 85 & $.35 \times .35 \mathrm{~m}$ Shovel Test & $\mathbf{P}$ \\
\hline 38 AK289 & 13 & 9 & 1 & $X$ & 90 & $.35 x .35 \mathrm{~m}$ Shovel Test & $\mathbf{P}$ \\
\hline $38 \mathrm{AK} 289$ & 13 & 9 & 2 & $\mathbf{X}$ & 85 & $.35 \times .35 \mathrm{~m}$ Shovel Test & $\mathbf{N}$ \\
\hline $38 \mathrm{AK} 289$ & 13 & 9 & 3 & $\mathbf{X}$ & 80 & $.35 \times .35 \mathrm{~m}$ Shovel Test & $\mathbf{N}$ \\
\hline 38 AK289 & 13 & 9 & 4 & $\mathbf{X}$ & 90 & $.35 \times .35 \mathrm{~m}$ Shovel Test & $\mathbf{N}$ \\
\hline 38 AK289 & 13 & 9 & 5 & $\mathbf{X}$ & 80 & $.35 \times .35 \mathrm{~m}$ Shovel Test & $\mathbf{N}$ \\
\hline $38 \mathrm{AK} 289$ & 13 & 9 & 6 & $\mathbf{X}$ & 85 & $.35 x .35 \mathrm{~m}$ Shovel Test & $\mathbf{N}$ \\
\hline 38 AK289 & 13 & 9 & 7 & $\mathbf{x}$ & 80 & $.35 x .35 \mathrm{~m}$ Shovel Test & $\mathbf{N}$ \\
\hline $38 \mathrm{AK} 289$ & 13 & 9 & 8 & $\mathbf{x}$ & 85 & $.35 \times .35 \mathrm{~m}$ Shovel Test & $\mathbf{N}$ \\
\hline $38 \mathrm{AK} 289$ & 13 & 9 & 9 & $\mathbf{X}$ & 85 & $.35 x .35 \mathrm{~m}$ Shovel Test & $\mathbf{N}$ \\
\hline $38 \mathrm{AK} 289$ & 13 & 9 & 10 & $\mathbf{X}$ & 95 & $.35 \times .35 \mathrm{~m}$ Shovel Test & $\mathbf{N}$ \\
\hline- & 13 & 9 & 11 & $\mathbf{X}$ & 100 & $.35 x .35 \mathrm{~m}$ Shovel Test & $\mathbf{N}$ \\
\hline- & 13 & 9 & 12 & $\mathbf{X}$ & 85 & $.35 \times .35 \mathrm{~m}$ Shovel Test & $\mathbf{N}$ \\
\hline $38 \mathrm{AK} 289$ & 13 & 9 & 13 & $\mathbf{X}$ & 80 & $.35 \times .35 \mathrm{~m}$ Shovel Test & $\mathbf{P}$ \\
\hline- & 13 & 9 & 14 & $\mathbf{X}$ & 80 & $.35 \times .35 \mathrm{~m}$ Shovel Test & $\mathbf{N}$ \\
\hline 38AK289 & 13 & 10 & 1 & $\mathbf{X}$ & 85 & $.35 x .35 \mathrm{~m}$ Shovel Test & $\mathbf{N}$ \\
\hline 38AK289 & 13 & 10 & 2 & $\mathrm{X}$ & 80 & $.35 x .35 \mathrm{~m}$ Shovel Test & $\mathbf{N}$ \\
\hline $38 \mathrm{AK} 289$ & 13 & 10 & 3 & $\mathbf{x}$ & 80 & $.35 x .35 \mathrm{~m}$ Shovel Test & $\mathbf{N}$ \\
\hline $38 \mathrm{AK} 289$ & 13 & 10 & 4 & $x$ & 80 & $.35 \times .35 \mathrm{~m}$ Shovel Test & $\mathbf{P}$ \\
\hline 38AK289 & 13 & 10 & 5 & $\mathrm{X}$ & 80 & $.35 \times .35 \mathrm{~m}$ Shovel Test & $\mathbf{N}$ \\
\hline 38 AK289 & 13 & 10 & 6 & $\mathrm{x}$ & 30 & $.35 \times .35 \mathrm{~m}$ Shovel Test & $\mathbf{N}$ \\
\hline $38 \mathrm{AK} 289$ & 13 & 10 & 7 & $\mathrm{X}$ & 80 & $.35 x .35 \mathrm{~m}$ Shovel Test & $\mathbf{N}$ \\
\hline 38 AK289 & 13 & 10 & 8 & $\mathbf{X}$ & 90 & $.35 \times .35 \mathrm{~m}$ Shovel Test & $\mathbf{N}$ \\
\hline- & 13 & 10 & 9 & $\mathbf{X}$ & 80 & $.35 x .35 \mathrm{~m}$ Shovel Test & $\mathbf{N}$ \\
\hline- & 13 & 10 & 10 & $\mathbf{X}$ & 90 & $.35 \times .35 \mathrm{~m}$ Shovel Test & $\mathbf{N}$ \\
\hline- & 13 & 10 & 11 & $\mathbf{X}$ & 80 & $.35 \times .35 \mathrm{~m}$ Shovel Test & $\mathbf{N}$ \\
\hline
\end{tabular}


Appendix A. (continued).

SHOVEL

BASAL

SHOVEL TEST

\begin{tabular}{|c|c|c|c|c|c|c|c|}
\hline SITE & PROV & TRANSECT & TEST & LEVEL* & DEPTH (cm BS) & NUMBER/TYPE & RESULTS** \\
\hline $38 \mathrm{AK} 289$ & 13 & 10 & 12 & $\mathbf{X}$ & 85 & $.35 x .35 \mathrm{~m}$ Shovel Test & $\mathbf{N}$ \\
\hline- & 13 & 10 & 13 & $\mathbf{x}$ & 75 & $.35 \times .35 \mathrm{~m}$ Shovel Test & $\mathbf{N}$ \\
\hline 38AK289 & 13 & 11 & 1 & $\mathbf{x}$ & 85 & $.35 \times .35 \mathrm{~m}$ Shovel Test & $\mathbf{N}$ \\
\hline 38AK289 & 13 & 11 & 2 & $\mathbf{x}$ & 90 & $.35 \times .35 \mathrm{~m}$ Shovel Test & $\mathbf{N}$ \\
\hline 38AK289 & 13 & 11 & 3 & $\mathbf{x}$ & 80 & $.35 x .35 \mathrm{~m}$ Shovel Test & $\mathbf{N}$ \\
\hline 38AK289 & 13 & 11 & 4 & $\mathbf{x}$ & 80 & $.35 \times .35 \mathrm{~m}$ Shovel Test & $\mathbf{N}$ \\
\hline 38AK289 & 13 & 11 & 5 & $\mathbf{x}$ & 80 & $.35 \times .35 \mathrm{~m}$ Shovel Test & $\mathbf{N}$ \\
\hline 38AK289 & 13 & 11 & 6 & $\mathbf{X}$ & 90 & $.35 \times .35 \mathrm{~m}$ Shovel Test & $\mathbf{P}$ \\
\hline- & 13 & 11 & 7 & $\mathbf{x}$ & 80 & $.35 x .35 \mathrm{~m}$ Shovel Test & $\mathbf{N}$ \\
\hline - & 13 & 11 & 8 & $\mathbf{X}$ & 90 & $.35 \times .35 \mathrm{~m}$ Shovel Test & $\mathbf{N}$ \\
\hline - & 13 & 11 & 9 & $\mathbf{x}$ & 80 & $.35 x .35 \mathrm{~m}$ Shovel Test & $\mathbf{N}$ \\
\hline - & 13 & 11 & 10 & $\mathbf{x}$ & 25 & $.35 x .35 \mathrm{~m}$ Shovel Test & $\mathbf{N}$ \\
\hline - & 13 & 11 & 11 & $\mathbf{X}$ & 25 & $.35 x .35 \mathrm{~m}$ Shovel Test & $\mathbf{N}$ \\
\hline 38AK289 & 13 & 11 & 12 & $\mathbf{X}$ & 30 & $.35 x .35 \mathrm{~m}$ Shovel Test & $\mathbf{N}$ \\
\hline 38 AK289 & 13 & 11 & 13 & $\mathbf{X}$ & 25 & $.35 x .35 \mathrm{~m}$ Shovel Test & $\mathbf{N}$ \\
\hline 38AK289 & 13 & 12 & 1 & $\mathbf{X}$ & 90 & $.35 x .35 \mathrm{~m}$ Shovel Test & $\mathbf{N}$ \\
\hline 38AK289 & 13 & 12 & 2 & $\mathbf{x}$ & 90 & $.35 \times .35 \mathrm{~m}$ Shovel Test & $\mathbf{P}$ \\
\hline 38AK289 & 13 & 12 & 3 & $\mathbf{X}$ & 90 & $.35 x .35 \mathrm{~m}$ Shovel Test & $\mathbf{N}$ \\
\hline- & 13 & 12 & 4 & $\mathbf{X}$ & 90 & $.35 x .35 \mathrm{~m}$ Shovel Test & $\mathbf{N}$ \\
\hline 38 AK289 & 13 & 13 & 1 & $\mathbf{X}$ & 85 & $.35 x .35 \mathrm{~m}$ Shovel Test & $\mathbf{P}$ \\
\hline $38 \mathrm{AK} 289$ & 13 & 13 & 2 & $\mathbf{X}$ & 110 & $.35 x .35 \mathrm{~m}$ Shovel Test & $\mathbf{P}$ \\
\hline 38 AK289 & 13 & 13 & 3 & $\mathbf{X}$ & 100 & $.35 \times .35 \mathrm{~m}$ Shovel Test & $\mathbf{P}$ \\
\hline 38AK289 & 13 & 13 & 4 & $\mathbf{X}$ & 100 & $.35 x .35 \mathrm{~m}$ Shovel Test & $\mathbf{p}$ \\
\hline- & 13 & 13 & 5 & $\mathbf{X}$ & 100 & $.35 \times .35 \mathrm{~m}$ Shovel Test & $\mathbf{N}$ \\
\hline- & 13 & 13 & 6 & $\mathbf{x}$ & 90 & $.35 x .35 \mathrm{~m}$ Shovel Test & $\mathbf{N}$ \\
\hline- & 13 & 13 & 7 & $\mathbf{X}$ & 85 & $.35 \times .35 \mathrm{~m}$ Shovel Test & $\mathbf{N}$ \\
\hline- & 13 & 13 & 8 & $\mathbf{X}$ & 95 & $.35 x .35 \mathrm{~m}$ Shovel Test & $\mathbf{N}$ \\
\hline - & 13 & 13 & 9 & $\mathbf{X}$ & 85 & $.35 \times .35 \mathrm{~m}$ Shovel Test & $\mathbf{N}$ \\
\hline - & 13 & 13 & 10 & $X$ & 95 & $.35 \times .35 \mathrm{~m}$ Shovel Test & $\mathbf{P}$ \\
\hline- & 13 & 13 & 11 & $\mathbf{x}$ & 90 & $.35 x .35 \mathrm{~m}$ Shovel Test & $\mathbf{N}$ \\
\hline- & 13 & 13 & 12 & $X$ & 95 & $.35 x .35 \mathrm{~m}$ Shovel Test & $\mathbf{N}$ \\
\hline- & 13 & 13 & 13 & $\mathbf{X}$ & 90 & $.35 \times .35 \mathrm{~m}$ Shovel Test & $\mathbf{N}$ \\
\hline- & 13 & 14 & 1 & $X$ & 95 & $.35 \times .35 \mathrm{~m}$ Shovel Test & $\mathbf{N}$ \\
\hline- & 13 & 14 & 2 & $\mathbf{x}$ & 90 & $.35 x .35 \mathrm{~m}$ Shovel Test & $\mathbf{N}$ \\
\hline- & 13 & 14 & 3 & $x$ & 90 & $.35 \times .35 \mathrm{~m}$ Shovel Test & $\mathbf{N}$ \\
\hline- & 13 & 14 & 4 & $\mathbf{X}$ & 95 & $.35 x .35 \mathrm{~m}$ Shovel Test & $\mathbf{N}$ \\
\hline- & 13 & 14 & 5 & $\mathbf{X}$ & 85 & $.35 \times .35 \mathrm{~m}$ Shovel Test & $\mathbf{N}$ \\
\hline- & 13 & 14 & 6 & $X$ & 85 & $.35 \times .35 \mathrm{~m}$ Shovel Test & $\mathbf{N}$ \\
\hline- & 13 & 14 & 7 & $\mathbf{X}$ & 80 & $.35 x .35 \mathrm{~m}$ Shovel Test & $\mathbf{N}$ \\
\hline- & 13 & 14 & 8 & $X$ & 85 & $.35 x .35 \mathrm{~m}$ Shovel Test & $\mathbf{N}$ \\
\hline - & 13 & 14 & 9 & $\mathbf{x}$ & 55 & $.35 \times .35 \mathrm{~m}$ Shovel Test & $\mathbf{N}$ \\
\hline- & 13 & 14 & 10 & $x$ & 30 & $.35 x .35 \mathrm{~m}$ Shovel Test & $\mathbf{N}$ \\
\hline - & 13 & 14 & 11 & $\mathrm{X}$ & 55 & $.35 \times .35 \mathrm{~m}$ Shovel Test & $\mathbf{N}$ \\
\hline - & 13 & 14 & 12 & $\mathbf{X}$ & 20 & $.35 x .35 \mathrm{~m}$ Shovel Test & $\mathbf{N}$ \\
\hline
\end{tabular}


Appendix A. (continued).

\begin{tabular}{|c|c|c|c|c|c|c|c|}
\hline & & & SHOVEL & & BASAL & & HHOVEL TEST \\
\hline SITE & PROV & TRANSECT & TEST & LEVEL* & DEPTH (cm BS) & NUMBER/TYPE & RESULTS** \\
\hline $38 \mathrm{AK} 289$ & 13 & 15 & 1 & $\mathrm{x}$ & 100 & $.35 x .35 \mathrm{~m}$ Shovel Test & $\mathbf{P}$ \\
\hline 38AK289 & 13 & 15 & 2 & $x$ & 95 & $.35 \times .35 \mathrm{~m}$ Shovel Test & $\mathbf{N}$ \\
\hline 38AK289 & 13 & 15 & 3 & $\mathrm{x}$ & 95 & $.35 \times .35 \mathrm{~m}$ Shovel Test & $\mathbf{N}$ \\
\hline 38AK289 & 13 & 16 & 1 & $\mathrm{X}$ & 100 & $.35 x .35 \mathrm{~m}$ Shovel Test & $\mathbf{P}$ \\
\hline 38AK289 & 13 & 16 & 2 & $\mathbf{x}$ & 90 & $.35 \times .35 \mathrm{~m}$ Shovel Test & $\mathbf{P}$ \\
\hline 38AK289 & 13 & 16 & 3 & $\mathbf{x}$ & 80 & $.35 \times .35 \mathrm{~m}$ Shovel Test & $\mathbf{P}$ \\
\hline 38AK289 & 13 & 16 & 4 & $\mathbf{x}$ & 35 & $.35 \times .35 \mathrm{~m}$ Shovel Test & $\mathbf{N}$ \\
\hline 38AK289 & 13 & 16 & 5 & $\mathbf{x}$ & 40 & $.35 x .35 \mathrm{~m}$ Shovel Test & $\mathbf{N}$ \\
\hline 38AK289 & 13 & 17 & 1 & $x$ & 35 & $.50 x .50 \mathrm{~m}$ Shovel Test & $\mathbf{P}$ \\
\hline 38AK289 & 13 & 17 & 2 & $\mathbf{x}$ & 90 & $.35 x .35 \mathrm{~m}$ Shovel Test & $\mathbf{P}$ \\
\hline 38AK289 & 13 & 17 & 3 & $\mathbf{x}$ & 60 & $.35 x .35 \mathrm{~m}$ Shovel Test & $\mathrm{N}$ \\
\hline 38 AK289 & 13 & 17 & 4 & $\mathbf{x}$ & 50 & $.35 x .35 \mathrm{~m}$ Shovel Test & $\mathbf{P}$ \\
\hline $38 \mathrm{AK} 289$ & 13 & 17 & 5 & $x$ & 40 & $.35 \times .35 \mathrm{~m}$ Shovel Test & $\mathbf{P}$ \\
\hline 38AK289 & 13 & 17 & 6 & $\mathrm{x}$ & 40 & $.35 x .35 \mathrm{~m}$ Shovel Test & $\mathbf{N}$ \\
\hline 38AK289 & 13 & 18 & 1 & $\mathrm{X}$ & 80 & $.35 x .35 \mathrm{~m}$ Shovel Test & $\mathbf{N}$ \\
\hline 38AK289 & 13 & 18 & 2 & $x$ & 90 & $.35 \times .35 \mathrm{~m}$ Shovel Test & $\mathbf{N}$ \\
\hline 38AK289 & 13 & 18 & 3 & $\mathrm{x}$ & 90 & $.35 x .35 \mathrm{~m}$ Shovel Test & $\mathbf{N}$ \\
\hline 38AK289 & 13 & 18 & 4 & $\mathrm{x}$ & 95 & $.35 x .35 \mathrm{~m}$ Shovel Test & $\mathbf{N}$ \\
\hline 38AK289 & 13 & 18 & 5 & $\mathrm{x}$ & 85 & $.35 x .35 \mathrm{~m}$ Shovel Test & $\mathbf{N}$ \\
\hline 38AK289 & 13 & 18 & 6 & $\mathrm{x}$ & 90 & $.35 \times .35 \mathrm{~m}$ Shovel Test & $\mathbf{N}$ \\
\hline 38AK289 & 13 & 18 & 7 & $\mathrm{x}$ & 90 & $.35 x .35 \mathrm{~m}$ Shovel Test & $\mathbf{N}$ \\
\hline 38AK289 & 13 & 18 & 8 & $\mathrm{x}$ & 85 & $.35 x .35 \mathrm{~m}$ Shovel Test & $\mathbf{N}$ \\
\hline 38AK289 & 13 & 18 & 9 & $x$ & 85 & $.35 x .35 \mathrm{~m}$ Shovel Test & $\mathbf{N}$ \\
\hline 38AK289 & 13 & 18 & 10 & $x$ & 85 & $.35 x .35 \mathrm{~m}$ Shovel Test & $\mathrm{N}$ \\
\hline 38AK289 & 13 & 18 & 11 & $\mathrm{x}$ & 90 & $.35 x .35 \mathrm{~m}$ Shovel Test & $\mathbf{N}$ \\
\hline 38 AK289 & 13 & 18 & 12 & $\mathrm{x}$ & 85 & $.35 x .35 \mathrm{~m}$ Shovel Test & $\mathbf{N}$ \\
\hline $38 \mathrm{AK} 289$ & 13 & 18 & 13 & $\mathbf{x}$ & 90 & $.35 x .35 \mathrm{~m}$ Shovel Test & $\mathrm{N}$ \\
\hline $38 \mathrm{AK} 289$ & 13 & 18 & 14 & $\mathrm{x}$ & 85 & $.35 x .35 \mathrm{~m}$ Shovel Test & $\mathbf{N}$ \\
\hline 38AK289 & 13 & 18 & 15 & $\mathrm{x}$ & 80 & $.35 x .35 \mathrm{~m}$ Shovel Test & $\mathrm{N}$ \\
\hline 38AK289 & 13 & 18 & 16 & $\mathrm{x}$ & 80 & $.35 x .35 \mathrm{~m}$ Shovel Test & $\mathbf{N}$ \\
\hline 38AK289 & 13 & 18 & 17 & $\mathbf{x}$ & 90 & $.35 x .35 \mathrm{~m}$ Shovel Test & $\mathbf{N}$ \\
\hline $38 \mathrm{AK} 289$ & 13 & 18 & 18 & $x$ & 80 & $.35 x .35 \mathrm{~m}$ Shovel Test & $\mathbf{N}$ \\
\hline 38AK289 & 13 & 18 & 19 & $\mathrm{x}$ & 90 & $.35 x .35 \mathrm{~m}$ Shovel Test & $\mathbf{N}$ \\
\hline 38AK289 & 13 & 18 & 20 & $x$ & 85 & $.35 x .35 \mathrm{~m}$ Shovel Test & $\mathbf{N}$ \\
\hline $38 \mathrm{AK} 289$ & 13 & 18 & 21 & $\mathrm{x}$ & 85 & $.35 x .35 \mathrm{~m}$ Shovel Test & N \\
\hline 38 AK289 & 13 & 18 & 22 & $x$ & 90 & $.35 x .35 \mathrm{~m}$ Shovel Test & $\mathbf{N}$ \\
\hline $38 \mathrm{AK} 289$ & 13 & 19 & 1 & $\mathbf{x}$ & 35 & $.35 x .35 \mathrm{~m}$ Shovel Test & $\mathbf{P}$ \\
\hline 38 AK289 & 13 & 19 & 2 & $\mathrm{x}$ & 35 & $.35 x .35 \mathrm{~m}$ Shovel Test & $\mathbf{P}$ \\
\hline 38AK289 & 13 & 20 & 1 & $x$ & 35 & $.35 x .35 \mathrm{~m}$ Shovel Test & $\mathbf{P}$ \\
\hline 38AK289 & 13 & 20 & 2 & $x$ & 35 & $.35 x .35 \mathrm{~m}$ Shovel Test & $\mathbf{P}$ \\
\hline 38AK289 & 13 & 20 & 3 & $\mathrm{x}$ & 35 & $.35 x .35 \mathrm{~m}$ Shovel Test & $\mathbf{N}$ \\
\hline 38AK289 & 13 & 20 & 4 & $x$ & 25 & $.35 x .35 \mathrm{~m}$ Shovel Test & $\mathbf{P}$ \\
\hline 38AK289 & 13 & 20 & 5 & $x$ & 25 & $.35 \times .35 \mathrm{~m}$ Shovel Test & N \\
\hline 38AK289 & 13 & 20 & 6 & $x$ & 25 & $.35 x .35 \mathrm{~m}$ Shovel Test & $\mathbf{N}$ \\
\hline
\end{tabular}


Appendix A. (continued).

SHOVEL

BASAL SHOVEL TEST

\begin{tabular}{|c|c|c|c|c|c|c|c|}
\hline SITE & PROV & TRANSECT & TEST & LEVEL* & DEPTH (cm BS) & NUMBER/TYPE & RESULTS** \\
\hline 38 AK 289 & 13 & 21 & 1 & $\mathrm{x}$ & 35 & $.35 \times .35 \mathrm{~m}$ Shovel Test & $\mathbf{P}$ \\
\hline 38AK289 & 13 & 21 & 2 & $\mathbf{x}$ & 35 & $.35 x .35 \mathrm{~m}$ Shovel Test & $\mathbf{P}$ \\
\hline 38AK289 & 13 & 21 & 3 & $\mathbf{x}$ & 35 & $.35 x .35 \mathrm{~m}$ Shovel Test & $\mathbf{P}$ \\
\hline 38AK289 & 13 & 21 & 4 & $\mathbf{x}$ & 30 & $.35 x .35 \mathrm{~m}$ Shovel Test & $\mathbf{P}$ \\
\hline 38AK289 & 13 & 22 & 1 & $\mathrm{x}$ & 70 & $.35 \times .35 \mathrm{~m}$ Shovel Test & $\mathbf{N}$ \\
\hline 38AK289 & 13 & 22 & 2 & $\mathbf{x}$ & 70 & $.35 x .35 \mathrm{~m}$ Shovel Test & $\mathbf{N}$ \\
\hline 38 AK289 & 13 & 22 & 3 & $\mathrm{x}$ & 80 & $.35 \times .35 \mathrm{~m}$ Shovel Test & $\mathbf{p}$ \\
\hline 38AK289 & 13 & 22 & 4 & $\mathbf{x}$ & 80 & $.35 x .35 \mathrm{~m}$ Shovel Test & $\mathbf{N}$ \\
\hline- & 13 & 23 & 1 & $\mathbf{x}$ & 80 & $.35 x .35 \mathrm{~m}$ Shovel Test & $\mathbf{N}$ \\
\hline- & 13 & 23 & 2 & $\mathbf{x}$ & 80 & $.35 x .35 \mathrm{~m}$ Shovel Test & $\mathbf{N}$ \\
\hline 38AK289 & 13 & 23 & 3 & $\mathbf{x}$ & 100 & $.35 x .35 \mathrm{~m}$ Shovel Test & $N$ \\
\hline 38AK289 & 13 & 23 & 4 & $\mathbf{x}$ & 100 & $.35 x .35 \mathrm{~m}$ Shovel Test & $\mathbf{P}$ \\
\hline 38 AK289 & 13 & 23 & 5 & $\mathrm{x}$ & 30 & $.35 x .35 \mathrm{~m}$ Shovel Test & $\mathbf{P}$ \\
\hline 38AK289 & 13 & 23 & 6 & $\mathbf{x}$ & 25 & $.35 x .35 \mathrm{~m}$ Shovel Test & $\mathbf{N}$ \\
\hline 38AK289 & 13 & 23 & 7 & $\mathbf{x}$ & 30 & $.35 x .35 \mathrm{~m}$ Shovel Test & $\mathbf{P}$ \\
\hline 38AK289 & 13 & 23 & 8 & $x$ & 25 & $.35 \times .35 \mathrm{~m}$ Shovel Test & $\mathbf{N}$ \\
\hline 38AK289 & 13 & 23 & 9 & $\mathrm{x}$ & 30 & $.35 \times .35 \mathrm{~m}$ Shovel Test & $\mathbf{P}$ \\
\hline 38AK289 & 13 & 23 & 10 & $\mathrm{x}$ & 30 & $.35 x .35 \mathrm{~m}$ Shovel Test & $\mathbf{P}$ \\
\hline 38AK289 & 13 & 23 & 11 & $x$ & 35 & $.35 x .35 \mathrm{~m}$ Shovel Test & $\mathbf{N}$ \\
\hline- & 13 & 23 & 12 & $\mathrm{x}$ & 30 & $.35 \times .35 \mathrm{~m}$ Shovel Test & $\mathbf{N}$ \\
\hline- & 13 & 23 & 13 & $\mathbf{x}$ & 30 & $.35 x .35 \mathrm{~m}$ Shovel Test & $\mathbf{N}$ \\
\hline 38AK289 & 13 & 24 & 1 & $\mathbf{x}$ & 60 & $.35 x .35 \mathrm{~m}$ Shovel Test & $\mathbf{P}$ \\
\hline 38AK289 & 13 & 24 & 2 & $\mathbf{x}$ & 90 & $.35 \times .35 \mathrm{~m}$ Shovel Test & $\mathbf{P}$ \\
\hline $38 \mathrm{AK} 289$ & 13 & 24 & 3 & $\mathbf{x}$ & 80 & $.35 x .35 \mathrm{~m}$ Shovel Test & $\mathbf{P}$ \\
\hline $38 \mathrm{AK} 289$ & 13 & 25 & 1 & $x$ & 90 & $.35 x .35 \mathrm{~m}$ Shovel Test & $\mathbf{P}$ \\
\hline $38 \mathrm{AK} 289$ & 13 & 25 & 2 & $\mathrm{x}$ & 115 & $.35 x .35 \mathrm{~m}$ Shovel Test & $\mathbf{P}$ \\
\hline $38 \mathrm{AK} 289$ & 13 & 25 & 3 & $\mathbf{x}$ & 105 & $.35 x .35 \mathrm{~m}$ Shovel Test & N \\
\hline 38AK289 & 13 & 25 & 4 & $\mathrm{x}$ & 105 & $.35 x .35 \mathrm{~m}$ Shovel Test & $N$ \\
\hline $38 \mathrm{AK} 289$ & 13 & 25 & 5 & $x$ & 95 & $.35 x .35 \mathrm{~m}$ Shovel Test & $\mathbf{N}$ \\
\hline 38AK289 & 13 & 25 & 6 & $x$ & 110 & $.35 x .35 \mathrm{~m}$ Shovel Test & $\mathbf{P}$ \\
\hline 38AK289 & 13 & 25 & 7 & $\mathrm{X}$ & 100 & $.35 \times .35 \mathrm{~m}$ Shovel Test & N \\
\hline $38 \mathrm{AK} 289$ & 13 & 25 & 8 & $\mathrm{x}$ & 95 & $.35 x .35 \mathrm{~m}$ Shovel Test & $\mathbf{P}$ \\
\hline 38AK289 & 13 & 25 & 9 & $x$ & 100 & $.35 \times .35 \mathrm{~m}$ Shovel Test & $\mathrm{N}$ \\
\hline 38AK289 & 13 & 25 & 10 & $\mathbf{x}$ & 100 & $.35 x .35 \mathrm{~m}$ Shovel Test & N \\
\hline $38 \mathrm{AK} 289$ & 13 & 25 & 11 & $\mathrm{x}$ & 100 & $.35 x .35 \mathrm{~m}$ Shovel Test & $\mathbf{P}$ \\
\hline 38AK289 & 13 & 25 & 12 & $\mathrm{x}$ & 100 & $.35 x .35 \mathrm{~m}$ Shovel Test & $\mathbf{P}$ \\
\hline 38AK289 & 13 & 25 & 13 & $\mathrm{x}$ & 100 & $.35 x .35 \mathrm{~m}$ Shovel Test & $\mathbf{P}$ \\
\hline 38AK289 & 13 & 25 & 14 & $\mathrm{x}$ & 100 & $.35 x .35 \mathrm{~m}$ Shovel Test & $\mathrm{N}$ \\
\hline $38 \mathrm{AK} 289$ & 13 & 25 & 15 & $\mathrm{x}$ & 100 & $.35 x .35 \mathrm{~m}$ Shovel Test & $\mathrm{N}$ \\
\hline 38AK289 & 13 & 25 & 16 & $\mathrm{x}$ & 100 & $.35 \times .35 \mathrm{~m}$ Shovel Test & $\mathbf{N}$ \\
\hline 38AK289 & 13 & 25 & 17 & $\mathrm{X}$ & 80 & $.35 x .35 \mathrm{~m}$ Shovel Test & $\mathbf{P}$ \\
\hline 38AK289 & 13 & 25 & 18 & $\mathrm{x}$ & 80 & $.35 x .35 \mathrm{~m}$ Shovel Test & $\mathrm{N}$ \\
\hline 38AK289 & 13 & 25 & 19 & $\mathrm{x}$ & 80 & $.35 x .35 \mathrm{~m}$ Shovel Test & $\mathbf{N}$ \\
\hline $38 \mathrm{AK289}$ & 13 & 25 & 20 & $\mathrm{X}$ & 105 & $.35 x .35 \mathrm{~m}$ Shovel Test & $\mathbf{P}$ \\
\hline
\end{tabular}


Appendix A. (continued).

SHOVEL

BASAL

SHOVEL TEST

\begin{tabular}{|c|c|c|c|c|c|c|c|}
\hline SITE & PROV & TRANSECT & TEST & LEVEL* & DEPTH (cm BS) & NUMBER/TYPE & RESULTS** \\
\hline 38AK289 & 13 & 25 & 21 & $\mathrm{X}$ & 100 & $.35 \times .35 \mathrm{~m}$ Shovel Test & $\mathbf{P}$ \\
\hline 38AK289 & 13 & 25 & 22 & $\mathbf{x}$ & 100 & $.35 x .35 \mathrm{~m}$ Shovel Test & $\mathbf{P}$ \\
\hline 38AK289 & 13 & 25 & 23 & $\mathrm{x}$ & 100 & $.35 x .35 \mathrm{~m}$ Shovel Test & $\mathbf{N}$ \\
\hline 38AK289 & 13 & 25 & 24 & $\mathbf{x}$ & 90 & $.35 x .35 \mathrm{~m}$ Shovel Test & $\mathbf{N}$ \\
\hline 38AK289 & 13 & 25 & 25 & $x$ & 90 & $.35 \times .35 \mathrm{~m}$ Shovel Test & $\mathbf{P}$ \\
\hline 38AK289 & 13 & 25 & 26 & $\mathbf{x}$ & 85 & $.35 x .35 \mathrm{~m}$ Shovel Test & $\mathbf{P}$ \\
\hline 38AK289 & 13 & 25 & 27 & $\mathbf{x}$ & 95 & $.35 x .35 \mathrm{~m}$ Shovel Test & $\mathbf{N}$ \\
\hline 38AK289 & 13 & 25 & 28 & $\mathbf{x}$ & 105 & $.35 \times .35 \mathrm{~m}$ Shovel Test & N \\
\hline 38AK289 & 13 & 25 & 29 & $\mathrm{x}$ & 95 & $.35 x .35 \mathrm{~m}$ Shovel Test & $\mathbf{N}$ \\
\hline 38AK289 & 13 & 25 & 30 & $\mathrm{x}$ & 95 & $.35 x .35 \mathrm{~m}$ Shovel Test & $\mathbf{N}$ \\
\hline 38AK289 & 13 & 25 & 31 & $\mathbf{x}$ & 100 & $.35 x .35 \mathrm{~m}$ Shovel Test & $\mathbf{N}$ \\
\hline 38AK289 & 13 & 25 & 32 & $\mathbf{x}$ & 100 & $.35 x .35 \mathrm{~m}$ Shovel Test & $\mathbf{N}$ \\
\hline 38AK289 & 13 & 25 & 33 & $\mathbf{x}$ & 85 & $.35 x .35 \mathrm{~m}$ Shovel Test & $\mathbf{N}$ \\
\hline 38AK289 & 13 & 25 & 34 & $\mathbf{x}$ & 95 & $.35 x .35 \mathrm{~m}$ Shovel Test & $\mathbf{N}$ \\
\hline 38AK289 & 13 & 25 & 35 & $x$ & 95 & $.35 x .35 \mathrm{~m}$ Shovel Test & $\mathbf{N}$ \\
\hline 38AK289 & 13 & 25 & 36 & $x$ & 100 & $.35 x .35 \mathrm{~m}$ Shovel Test & $\mathbf{N}$ \\
\hline 38AK289 & 13 & 25 & 37 & $\mathbf{x}$ & 80 & $.35 x .35 \mathrm{~m}$ Shovel Test & $\mathbf{N}$ \\
\hline 38AK289 & 13 & 25 & 38 & $x$ & 80 & $.35 x .35 \mathrm{~m}$ Shovel Test & $\mathbf{N}$ \\
\hline 38AK289 & 13 & 25 & 39 & $\mathbf{x}$ & 100 & $.35 x .35 \mathrm{~m}$ Shovel Test & $\mathbf{N}$ \\
\hline 38AK289 & 13 & 25 & 40 & $x$ & 95 & $.35 x .35 \mathrm{~m}$ Shovel Test & $\mathbf{N}$ \\
\hline 38AK289 & 13 & 25 & 41 & $\mathbf{x}$ & 105 & $.35 x .35 \mathrm{~m}$ Shovel Test & $\mathbf{P}$ \\
\hline 38AK289 & 13 & 25 & 42 & $\mathrm{x}$ & 95 & $.35 \times .35 \mathrm{~m}$ Shovel Test & $\mathbf{N}$ \\
\hline 38AK289 & 13 & 25 & 43 & $\mathbf{x}$ & 95 & $.35 x .35 \mathrm{~m}$ Shovel Test & $\mathbf{N}$ \\
\hline 38AK289 & 14 & - & - & $\mathbf{A}$ & 10 & $1 \times 2 \mathrm{~m}$; Arbitrary Level & - \\
\hline 38AK289 & 14 & - & - & B & 20 & $1 \times 2 \mathrm{~m}$; Arbitrary Level & - \\
\hline 38AK289 & 14 & - & - & C & 25 & $1 \times 2 \mathrm{~m}$; Arbitrary Level & - \\
\hline 38AK289 & 14 & - & - & D & 30 & 1×2 m; Arbitrary Level & - \\
\hline 38AK289 & 14 & - & - & $\mathrm{E}$ & 35 & 1×2 m; Arbitrary Level & - \\
\hline 38AK289 & 14 & - & - & F & 40 & $1 \times 2 \mathrm{~m}$; Arbitrary Level & - \\
\hline 38AK289 & 14 & - & - & G & 45 & $1 \times 2 \mathrm{~m}$; Arbitrary Level & - \\
\hline 38AK289 & 14 & - & - & H & 50 & $1 \times 2 \mathrm{~m}$; Arbitrary Level & - \\
\hline 38AK289 & 14 & - & - & I & 55 & $1 \times 2 \mathrm{~m}$; Arbitrary Level & - \\
\hline 38AK289 & 14 & - & - & $J$ & 60 & 1×2 m; Arbitrary Level & - \\
\hline 38AK289 & 14 & - & - & K & 65 & $1 \times 2 \mathrm{~m}$; Arbitrary Level & - \\
\hline $38 \mathrm{AK} 289$ & 14 & - & - & L & 70 & $1 \times 2 \mathrm{~m}$; Arbitrary Level & - \\
\hline 38AK289 & 14 & - & - & M & 75 & $1 \times 2 \mathrm{~m}$; Arbitrary Level & - \\
\hline $38 \mathrm{AK} 289$ & 14 & - & - & $\mathbf{N}$ & 80 & $1 \times 2 \mathrm{~m}$; Arbitrary Level & - \\
\hline $38 \mathrm{AK} 289$ & 14 & - & - & 0 & 85 & $1 \times 2 \mathrm{~m}$; Arbitrary Level & - \\
\hline 38AK289 & 14 & - & - & $\mathbf{P}$ & 90 & $1 \times 2 \mathrm{~m}$; Arbitrary Level & - \\
\hline $38 \mathrm{AK} 289$ & 14 & - & - & Q & 95 & $1 \times 2 \mathrm{~m}$; Arbitrary Level & - \\
\hline $38 \mathrm{AK} 289$ & 14 & - & - & $\mathbf{R}$ & 100 & $1 \times 2 \mathrm{~m}$; Arbitrary Level & - \\
\hline 38AK466 & 1 & - & - & $\varnothing$ & - & Surface Grab Collection & $\cdot$ \\
\hline $38 \mathrm{AK} 466$ & 2 & - & 1 & $x$ & 80 & $.35 x .35 \mathrm{~m}$ Shovel Test & $\mathbf{P}$ \\
\hline
\end{tabular}


Appendix A. (continued).

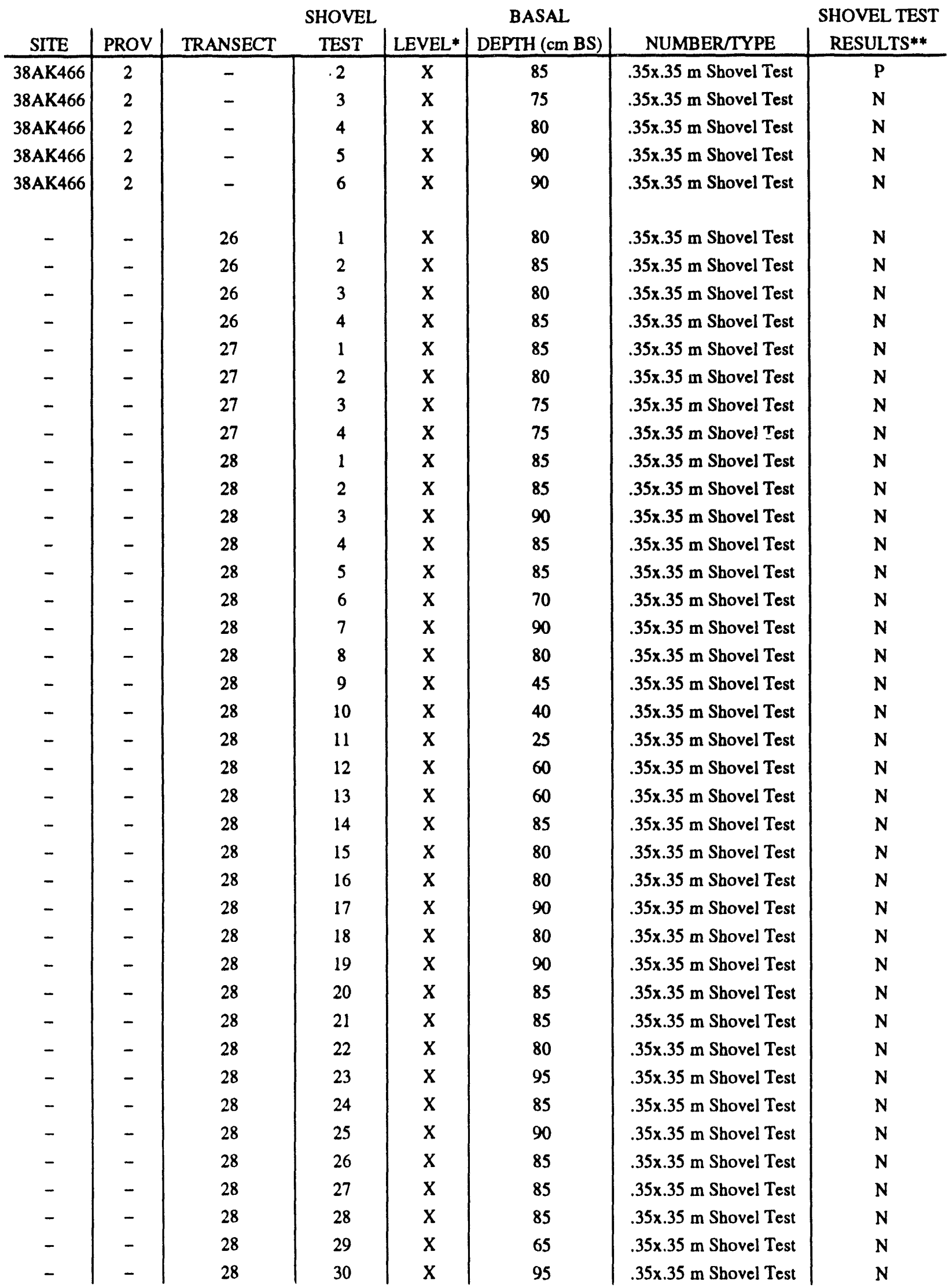


Appendix A. (continued).

\begin{tabular}{|c|c|c|c|c|c|c|c|}
\hline & & & SHOVEL & & BASAL & & SHOVEL TEST \\
\hline SITE & PROV & TRANSECT & TEST & LEVEL* & DEPTH (cm BS) & NUMBER/TYPE & RESULTS** \\
\hline - & - & 28 & 31 & $\mathbf{x}$ & 80 & $.35 x .35 \mathrm{~m}$ Shovel Test & $\mathbf{N}$ \\
\hline - & - & 28 & 32 & $\mathbf{x}$ & 85 & $.35 x .35 \mathrm{~m}$ Shovel Test & $\mathbf{N}$ \\
\hline - & - & 28 & 33 & $\mathbf{x}$ & 90 & $.35 x .35 \mathrm{~m}$ Shovel Test & $\mathbf{N}$ \\
\hline - & - & 28 & 34 & $\mathbf{x}$ & 80 & $.35 \times .35 \mathrm{~m}$ Shovel Test & $\mathbf{N}$ \\
\hline - & - & 28 & 35 & $\mathbf{x}$ & 85 & $.35 x .35 \mathrm{~m}$ Shovel Test & $\mathbf{N}$ \\
\hline - & - & 28 & 36 & $x$ & 85 & $.35 x .35 \mathrm{~m}$ Shovel Test & $\mathbf{N}$ \\
\hline - & - & 28 & 37 & $\mathbf{X}$ & 85 & $.35 x .35 \mathrm{~m}$ Shovel Test & $\mathbf{N}$ \\
\hline - & - & 28 & 38 & $\mathbf{x}$ & 90 & $.35 \times .35 \mathrm{~m}$ Shovel Test & $\mathbf{N}$ \\
\hline - & - & 28 & 39 & $\mathrm{X}$ & 90 & $.35 x .35 \mathrm{~m}$ Shovel Test & $\mathbf{N}$ \\
\hline - & - & 29 & 1 & $\mathbf{x}$ & 40 & $.35 x .35 \mathrm{~m}$ Shovel Test & $\mathbf{N}$ \\
\hline - & - & 29 & 2 & $\mathbf{X}$ & 30 & $.35 x .35 \mathrm{~m}$ Shovel Test & $\mathbf{N}$ \\
\hline - & - & 29 & 3 & $\mathbf{x}$ & 25 & $.35 x .35 \mathrm{~m}$ Shovel Test & $\mathbf{N}$ \\
\hline - & - & 29 & 4 & $\mathbf{X}$ & 30 & $.35 \times .35 \mathrm{~m}$ Shovel Test & $\mathbf{N}$ \\
\hline - & - & 29 & 5 & $\mathbf{x}$ & 30 & $.35 x .35 \mathrm{~m}$ Shovel Test & $\mathbf{N}$ \\
\hline - & - & 29 & 6 & $\mathbf{X}$ & 40 & $.35 x .35 \mathrm{~m}$ Shovel Test & $\mathbf{N}$ \\
\hline - & - & 30 & 1 & $\mathbf{X}$ & 60 & $.35 x .35 \mathrm{~m}$ Shovel Test & $\mathbf{N}$ \\
\hline - & - & 30 & 2 & $\mathrm{X}$ & 90 & $.35 x .35 \mathrm{~m}$ Shovel Test & $\mathbf{N}$ \\
\hline - & - & 30 & 3 & $\mathbf{x}$ & 80 & $.35 x .35 \mathrm{~m}$ Shovel Test & $\mathbf{N}$ \\
\hline - & - & 30 & 4 & $\mathbf{x}$ & 30 & $.35 x .35 \mathrm{~m}$ Shovel Test & $\mathbf{N}$ \\
\hline - & - & 30 & 5 & $\mathbf{x}$ & 20 & $.35 \times .35 \mathrm{~m}$ Shovel Test & $\mathbf{N}$ \\
\hline - & - & 30 & 6 & $\mathbf{x}$ & 30 & $.35 x .35 \mathrm{~m}$ Shovel Test & $\mathbf{N}$ \\
\hline - & - & 30 & 7 & $\mathbf{x}$ & 40 & $.35 x .35 \mathrm{~m}$ Shovel Test & $\mathbf{N}$ \\
\hline - & - & 30 & 8 & $\mathbf{x}$ & 80 & $.35 x .35 \mathrm{~m}$ Shovel Test & $\mathbf{N}$ \\
\hline - & - & 30 & 9 & $\mathbf{x}$ & 85 & $.35 x .35 \mathrm{~m}$ Shovel Test & $\mathbf{N}$ \\
\hline - & - & 30 & 10 & $\mathrm{X}$ & 85 & $.35 \times .35 \mathrm{~m}$ Shovel Test & $\mathbf{N}$ \\
\hline - & - & 30 & 11 & $\mathbf{x}$ & 90 & $.35 x .35 \mathrm{~m}$ Shovel Test & $\mathbf{N}$ \\
\hline - & - & 30 & 12 & $\mathbf{X}$ & 75 & $.35 x .35 \mathrm{~m}$ Shovel Test & $\mathbf{N}$ \\
\hline
\end{tabular}

*Level codes: $\mathrm{X}=$ Entire shovel test; other alpha codes=excavation level.

**STP Results Codes: $P=$ Positive shovel test; $N=$ Negative shovel test. 
Appendix B. Artifact Inventory, 38AK289.

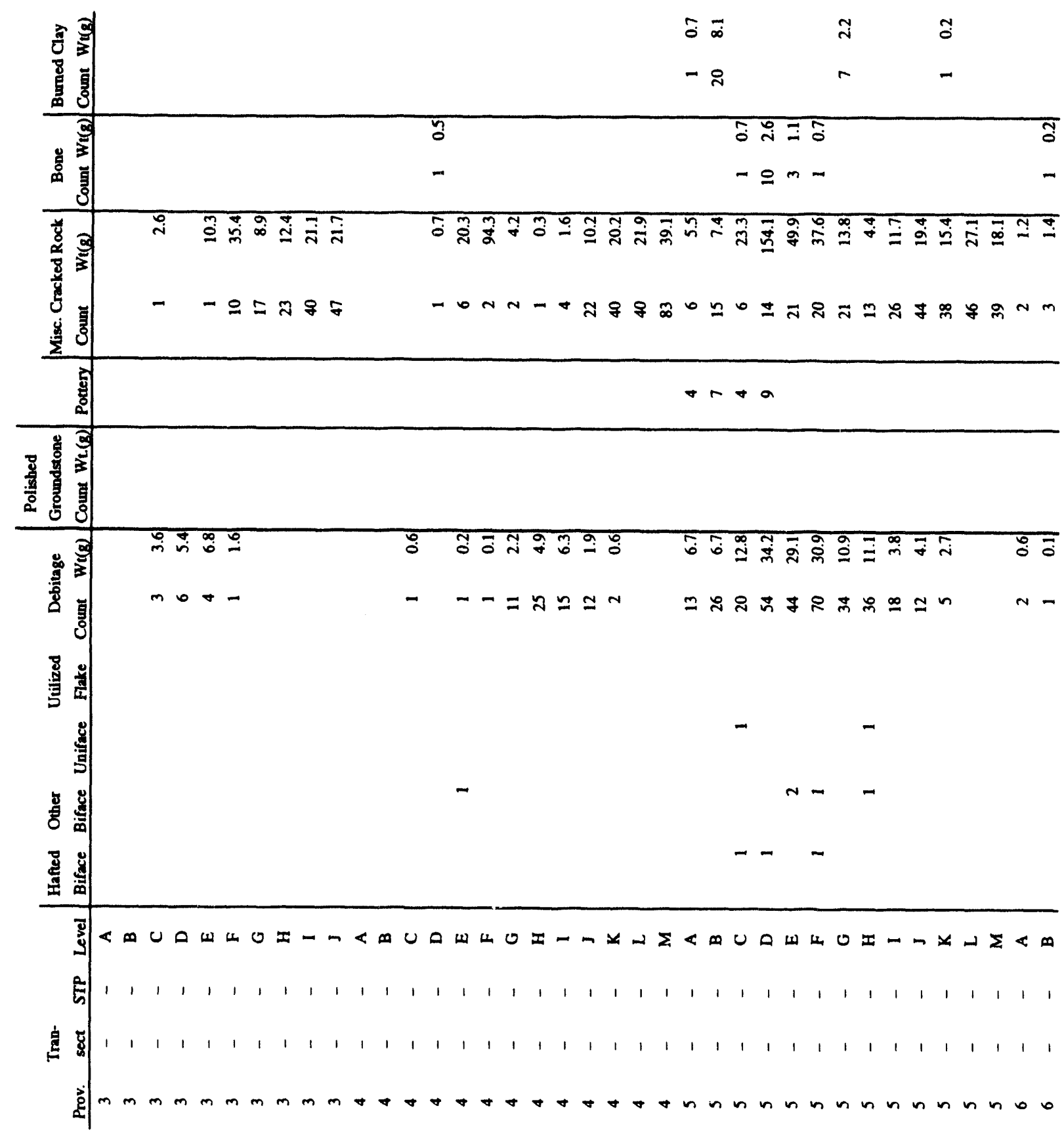


Appendix B. (continued).

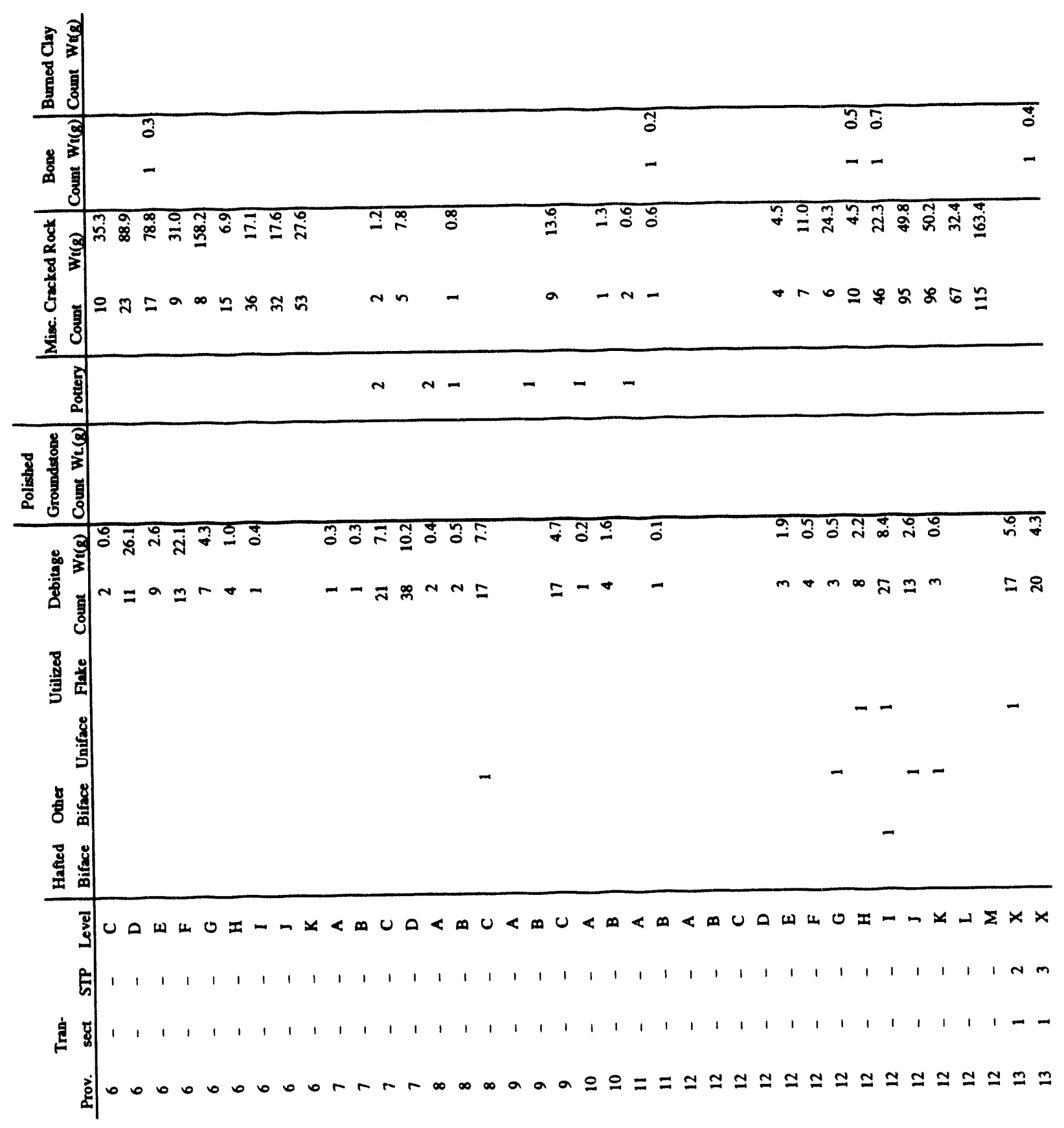


Appendix B. (continued).

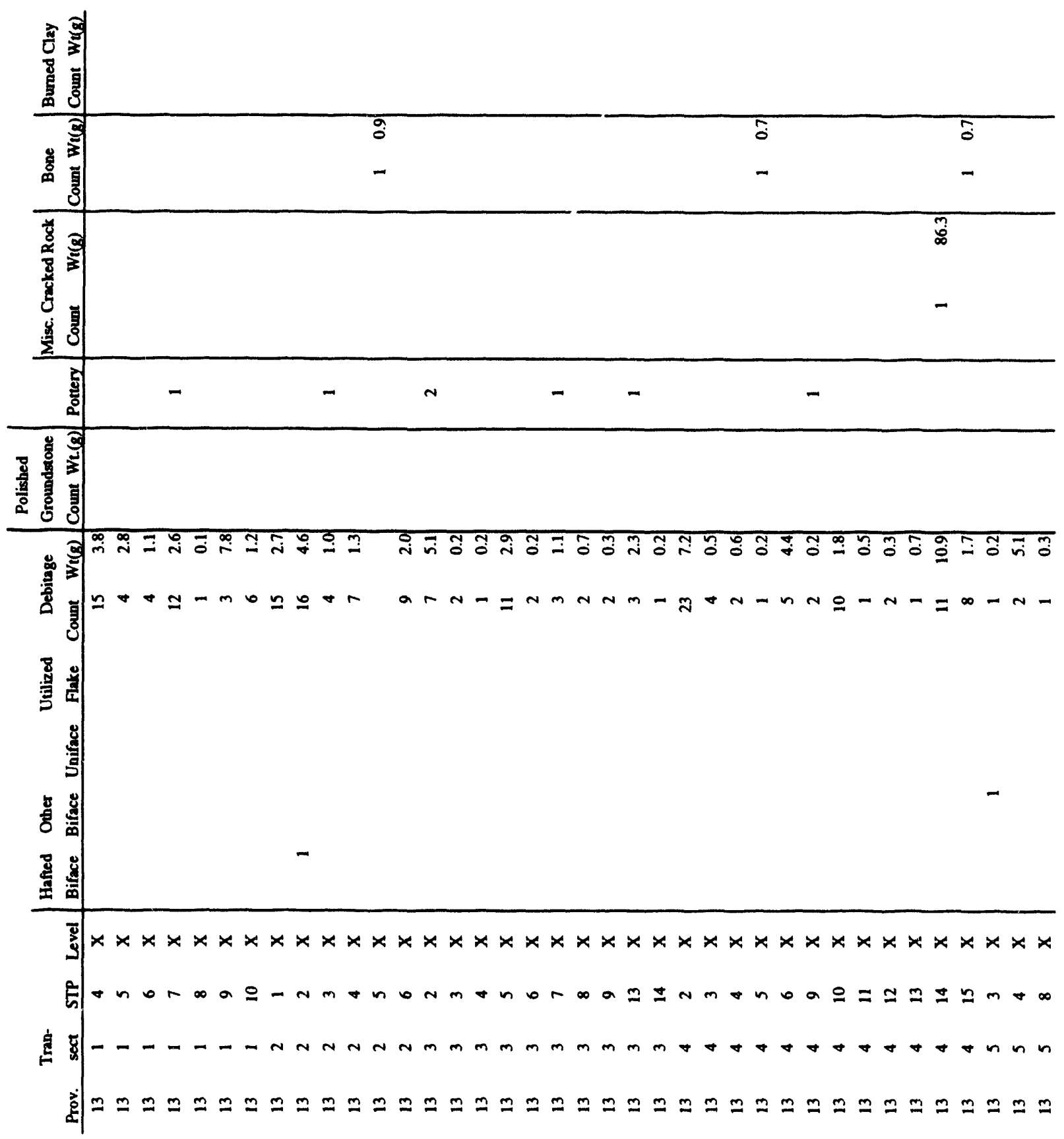




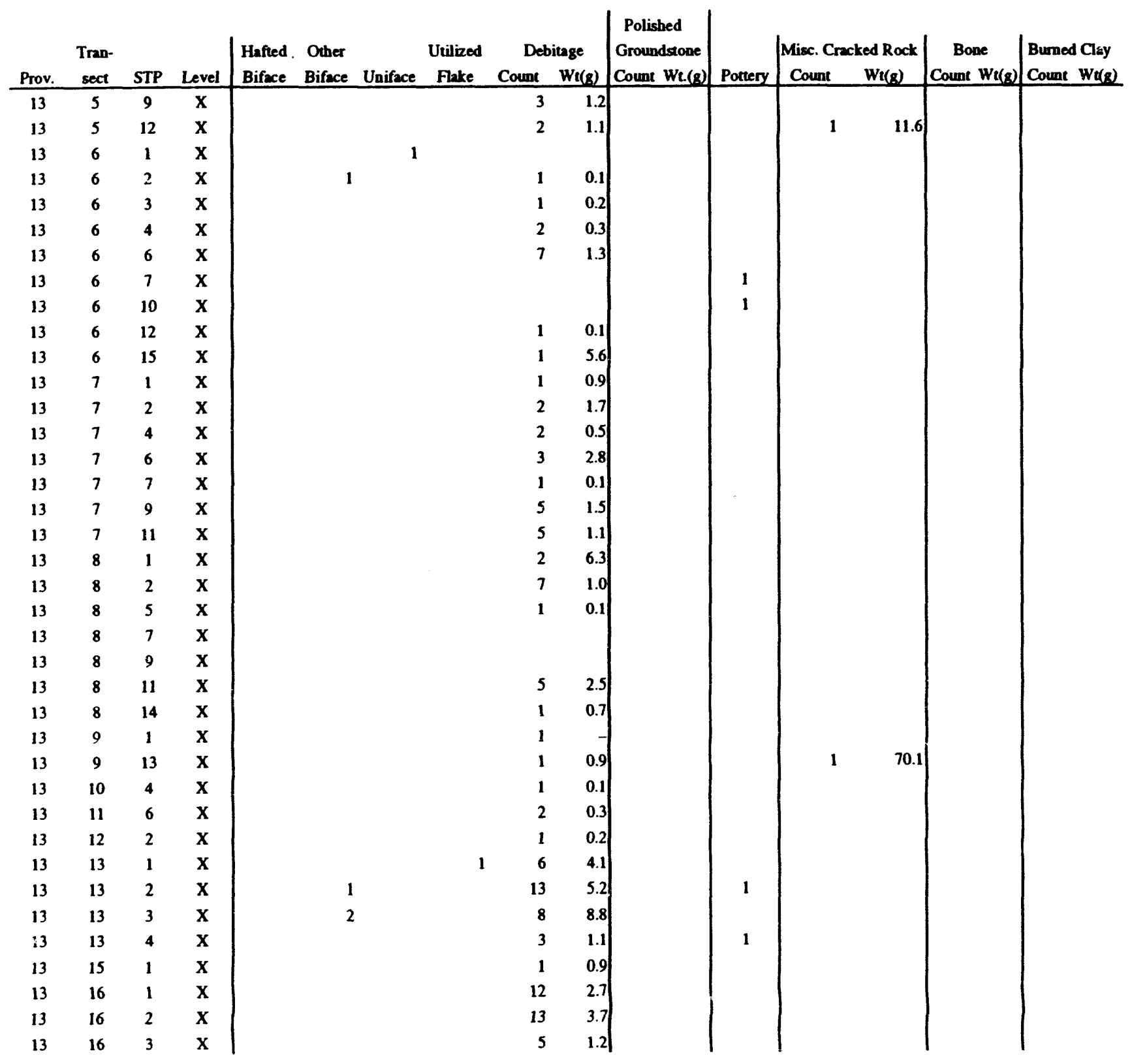




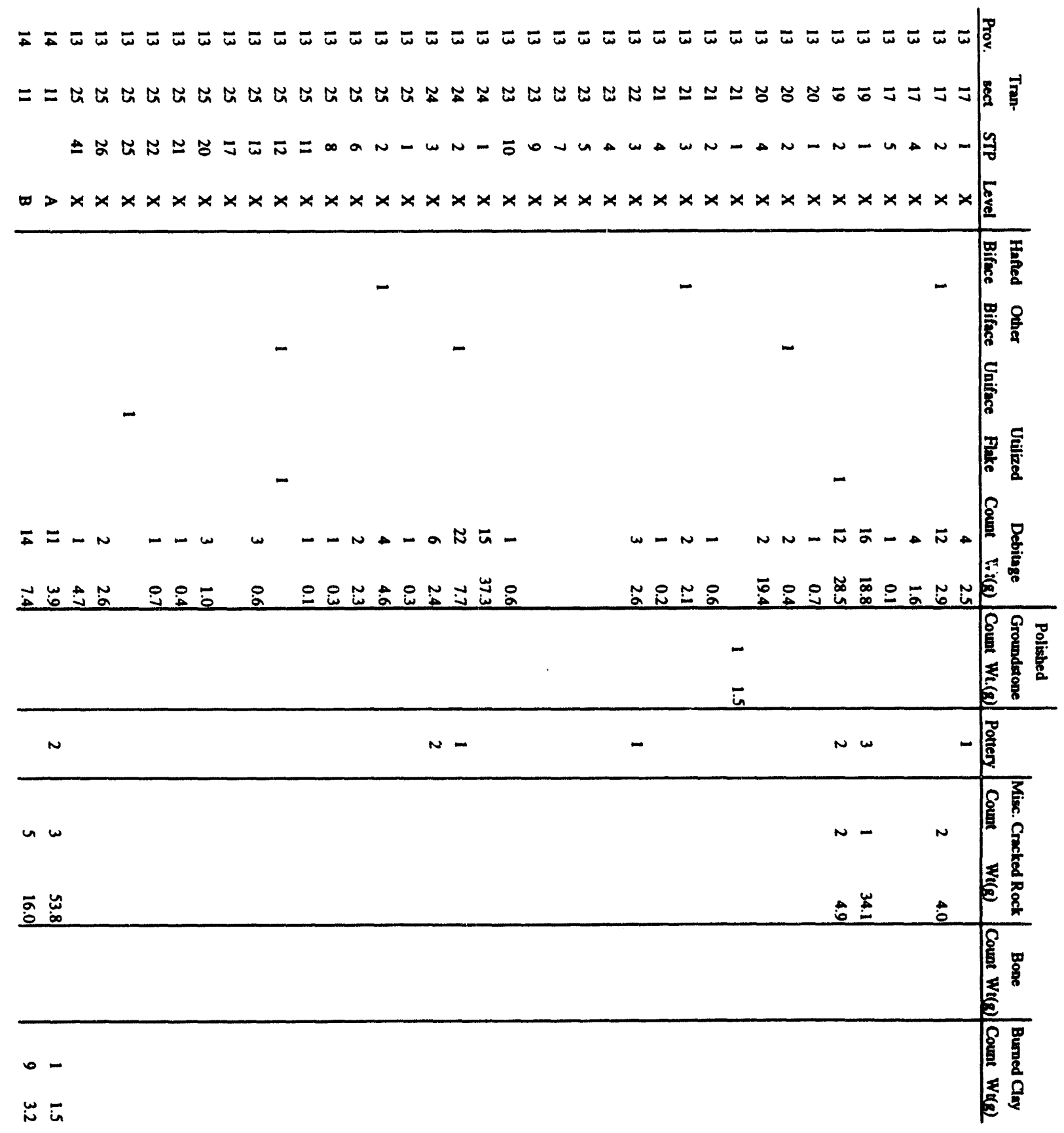

'(pənuṇuos) 'g xịpuaddy 
Appendices

97

Appendix B. (continued).

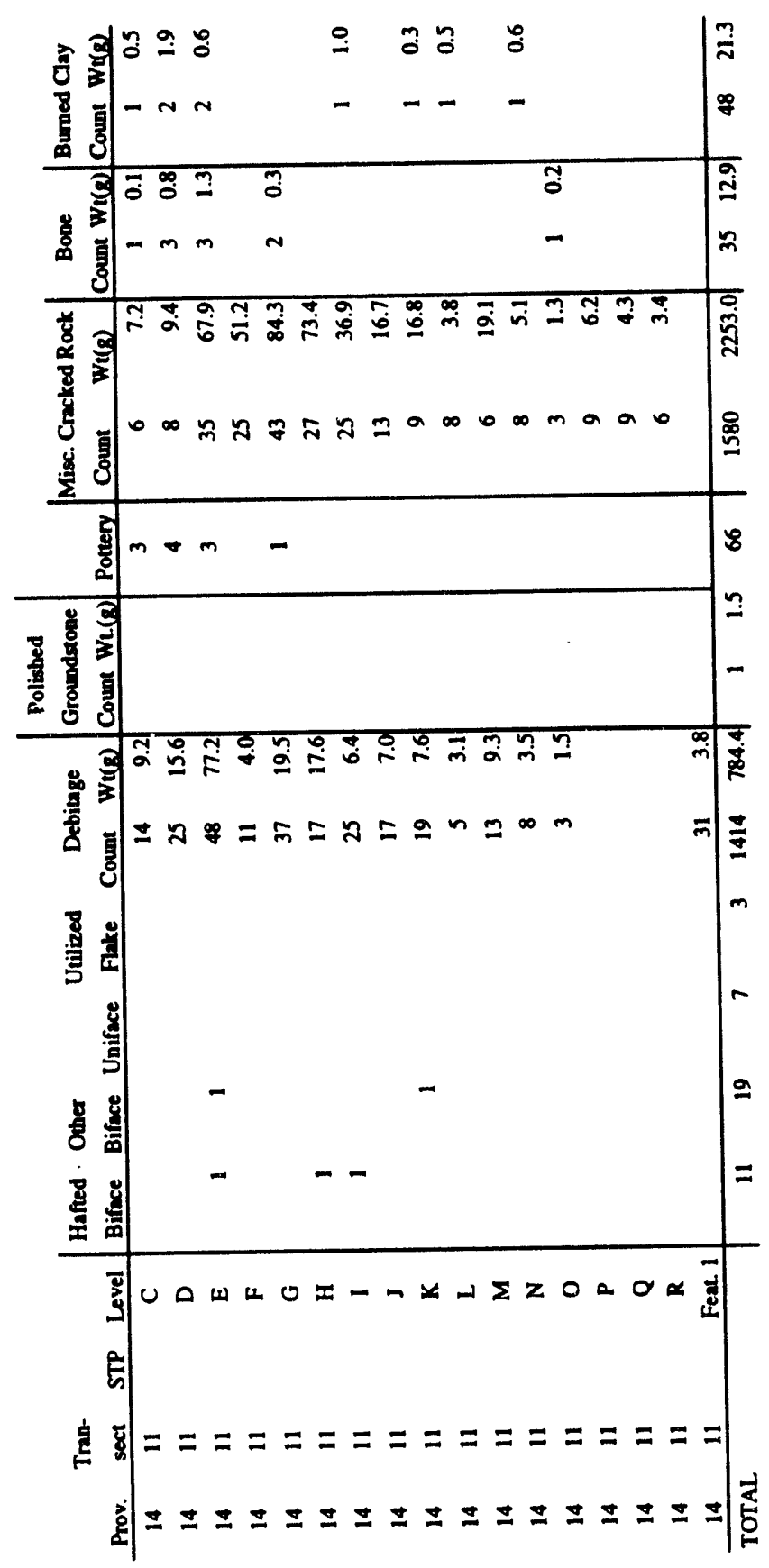


Appendix C. Artifact Inventory, 38AK287.

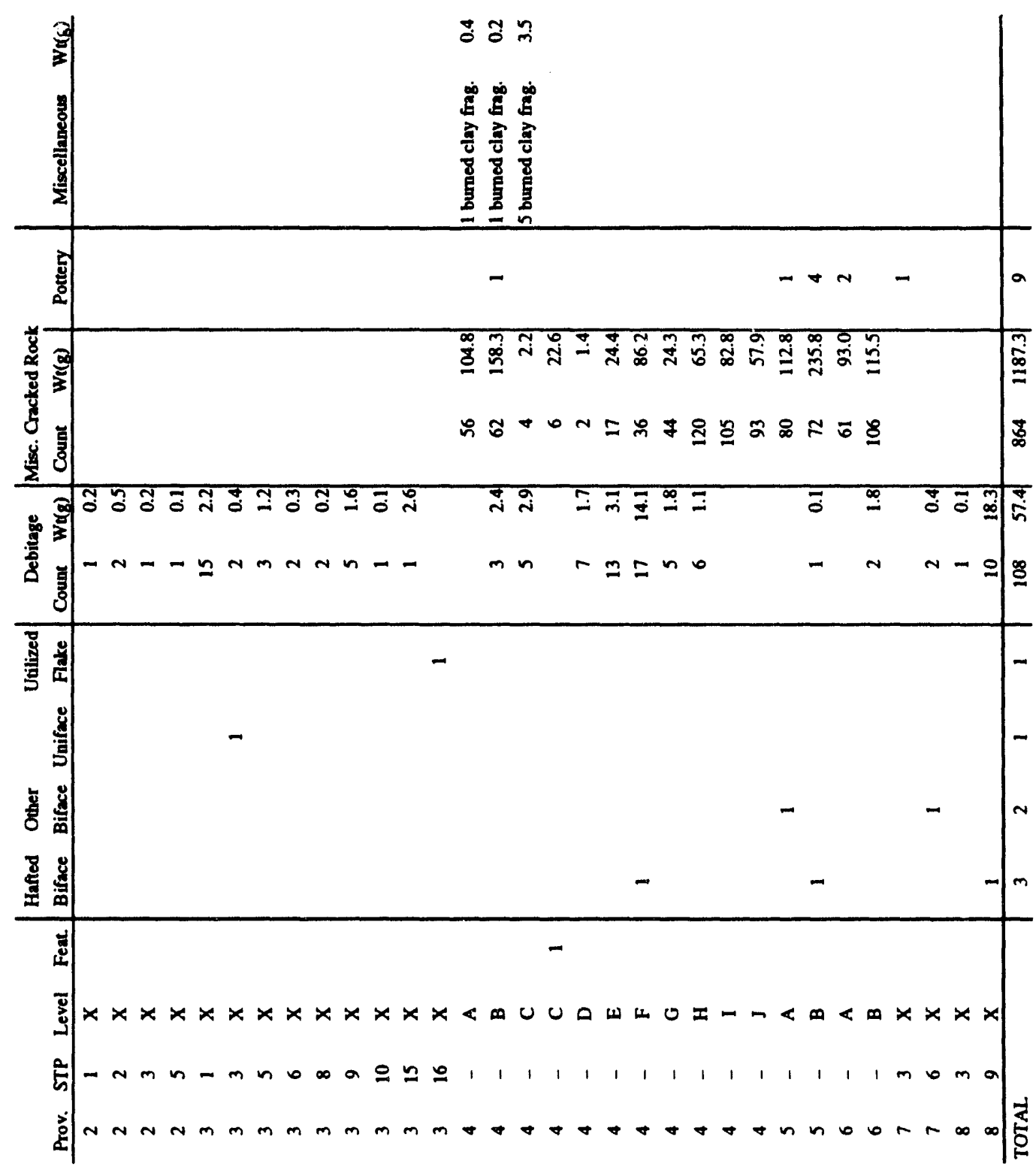



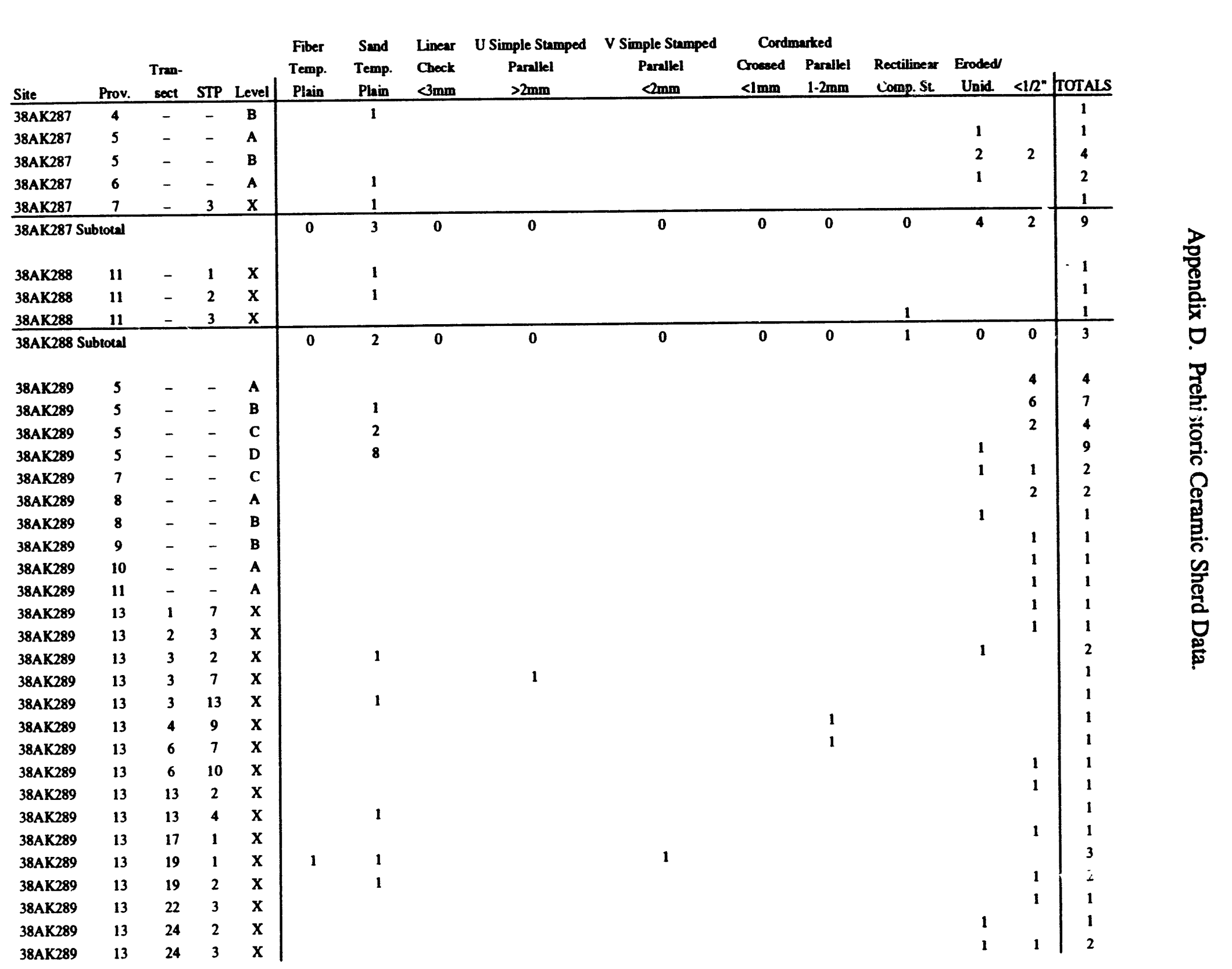


\begin{tabular}{|c|c|c|c|c|c|c|c|c|c|c|c|c|c|c|c|}
\hline \multirow[b]{2}{*}{ Site } & \multirow[b]{2}{*}{ Prov. } & \multirow[b]{2}{*}{$\begin{array}{l}\text { Tran- } \\
\text { sect }\end{array}$} & \multirow[b]{2}{*}{ STP } & \multirow[b]{2}{*}{ Level } & \multirow{2}{*}{$\begin{array}{l}\text { Fiber } \\
\text { Temp. } \\
\text { Plain }\end{array}$} & \multirow{2}{*}{$\begin{array}{l}\text { Sand } \\
\text { Temp. } \\
\text { Plain } \\
\end{array}$} & \multirow{2}{*}{$\begin{array}{l}\text { Linear } \\
\text { Check } \\
<3 \mathrm{~mm}\end{array}$} & \multirow{2}{*}{$\begin{array}{c}\text { U Simple Stamped } \\
\text { Parallel } \\
>2 \mathrm{~mm} \\
\end{array}$} & \multirow{2}{*}{$\begin{array}{c}\text { V Simple Stamped } \\
\text { Parnllel } \\
\text { <mmm } \\
\end{array}$} & \multicolumn{2}{|c|}{ Cordmarked } & \multirow[b]{2}{*}{$\begin{array}{l}\text { Rectilinear } \\
\text { Comp. St. }\end{array}$} & \multirow[b]{2}{*}{$\begin{array}{c}\text { Eroded } \\
\text { Unid. }\end{array}$} & \multirow[b]{2}{*}{$<12^{*}$} & \multirow[b]{2}{*}{ TOTALS } \\
\hline & & & & & & & & & & $\begin{array}{l}\text { Crossed } \\
<\operatorname{lmm} \\
\end{array}$ & $\begin{array}{l}\text { Parallel } \\
1.2 \mathrm{~mm} \\
\end{array}$ & & & & \\
\hline $38 \mathrm{AK} 289$ & 14 & - & - & A & & & 1 & & & 1 & & & & & 2 \\
\hline 38 AK289 & 14 & - & - & c & & 1 & & & & & & & & 2 & 3 \\
\hline 38AK289 & 14 & - & - & D & & 1 & & & & & & & & 3 & 4 \\
\hline 38AK289 & 14 & - & - & $\mathbf{E}$ & & 2 & & & & & & & & 1 & 3 \\
\hline 38AK289 & 14 & - & - & $\mathbf{G}$ & & & & & & & & & & 1 & 1 \\
\hline \multicolumn{5}{|c|}{ 38AK289 Subtotal } & 1 & 20 & 1 & 1 & 1 & 1 & 2 & 0 & 6 & 33 & 66 \\
\hline \multicolumn{5}{|c|}{ TOTAL } & 1 & 25 & 1 & 1 & 1 & 1 & 2 & 1 & 10 & 35 & 78 \\
\hline
\end{tabular}


Appendix E. Hafted Biface Data.

\begin{tabular}{|c|c|c|c|c|c|c|c|c|c|c|c|c|c|c|c|c|c|c|}
\hline Sile & Prov & $\begin{array}{l}\text { Tran- } \\
\text { seat }\end{array}$ & STP & Leved & trye & $\begin{array}{c}\text { Raw } \\
\text { Maverial }\end{array}$ & Condition & Freaure & $\begin{array}{c}\text { Max. } \\
\text { Lengeth }\end{array}$ & $\begin{array}{l}\text { Max. } \\
\text { Widath }\end{array}$ & Max. & $\begin{array}{c}\text { Proximal } \\
\text { Haft } \\
\text { Eemeat } \\
\text { Wiath }\end{array}$ & $\begin{array}{c}\text { Diseal } \\
\text { Heff } \\
\text { Eement } \\
\text { Wiath }\end{array}$ & $\begin{array}{c}\text { Hant } \\
\text { Eement } \\
\text { Lempen }\end{array}$ & Heft & $\begin{array}{l}\text { Benal } \\
\text { Smape }\end{array}$ & $w(x)$ & Noles \\
\hline $38 \mathrm{AK} 287$ & 4 & - & - & $\mathbf{F}$ & Kirk & QTZ & Whole & & 48.9 & 232 & 8.5 & 23.3 & 198 & 13.9 & Conser-Nouched & Suralght & 7.0 & resterpened \\
\hline $38 A \times 287$ & 5 & - & - & B & SMST & TAC & Broken & Laveral Suap & - & 19.5 & 62 & 7.9 & 78 & 3.2 & Sterrmed & Convex & 3.8 & ip abeepti beend damage \\
\hline $38 A K 287$ & 8 & 8 & 9 & $\mathbf{x}$ & SMTR & TAC & Brokem & Diagonat Snap & - & 21.7 & 4. & 21.7 & - & & Triangular & Concave & 1.7 & ip abeent \\
\hline 38AK289 & 5 & - & - & c & Badin & TAC & Broken & Perverse Sasp & - & 21.4 & 9.5 & 21.4 & - & & Triangular & Suright & 3.4 & Jip stoent \\
\hline 38AK289 & $s$ & - & - & D & Unident. & TAC & Brokem & & - & - & - & - & - & 8.2 & Stemmed & - & 0.3 & only owe edy of then decreat present \\
\hline 38AK289 & 5 & - & - & $\mathbf{F}$ & SRST & TAC & Brokan & & 43.4 & 362 & 10.1 & 195 & 19.9 & 8.5 & Stemmed & Convex & 14.0 & 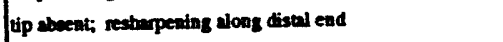 \\
\hline 38AK289 & 12 & - & - & I & Taylor & TAC & Broken & Laveral Sanp & - & - & - & 22.1 & 16.7 & 11.8 & Side-Notched & Concave & 2.2 & majodity of bade abseat \\
\hline 38AK289 & 13 & 2 & 2 & $\mathbf{x}$ & MaLA & TAC & Broken & Lateral Snap & - & - & 78 & - & 11.8 & 9.6 & Stremmed & Surajght & 5.1 & mid-ecction and portion of proximal tan etemeat absent \\
\hline 38AK289 & 13 & 17 & 2 & $\mathbf{x}$ & SMST & CPC & Whote & Potid & 435 & - & 7.1 & 13.5 & 14.5 & 12.6 & Stemmed & Straight & 3.7 & portions of mid-ection abseat dee to berning \\
\hline $38 A K 289$ & 13 & 21 & 3 & $\mathbf{x}$ & SMST & TAC & Broken & Han Snap & - & - & - & 14.1 & - & 10.5 & Stermmed & Convex & 2.3 & majonty of bisce absent \\
\hline $38 \wedge \times 289$ & 13 & 25 & 2 & $\mathbf{x}$ & KCN & $\infty \mathrm{pr}$ & Broken & Han Snap & - & - & - & 22.4 & - & - & Conner-Nouctied & Sorright & 0.7 & only beal pord on of than everrent present \\
\hline 38AK289 & 14 & - & - & $\mathbf{E}$ & мM & TAC & Whoke & & 33.7 & 21.9 & 72 & 6.5 & 13.0 & 10.5 & Stemrned & Rounded & 3.5 & \\
\hline 38AK289 & 14 & - & - & н & SRST-ilike & TAC & Whole & Edge Fracture & 53.1 & 22.7 & 9.9 & 14.4 & 16.5 & 10.3 & Stermmed & Suraight & 11.1 & 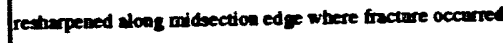 \\
\hline 38AK289 & 14 & - & - & I & MM & TAC & Broken & Han Snap & - & - & - & 6.9 & 15.1 & 12.8 & Svemmed & Rounded & 2.0 & Oonly ban element prescent \\
\hline
\end{tabular}

All liner measurements recorded in millimeler.

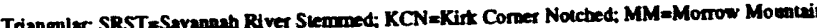

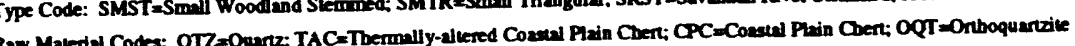

Frecture Patuen Coder: EDG-Longiudinal Edge Snap 
Appendix F. Other Biface Data.

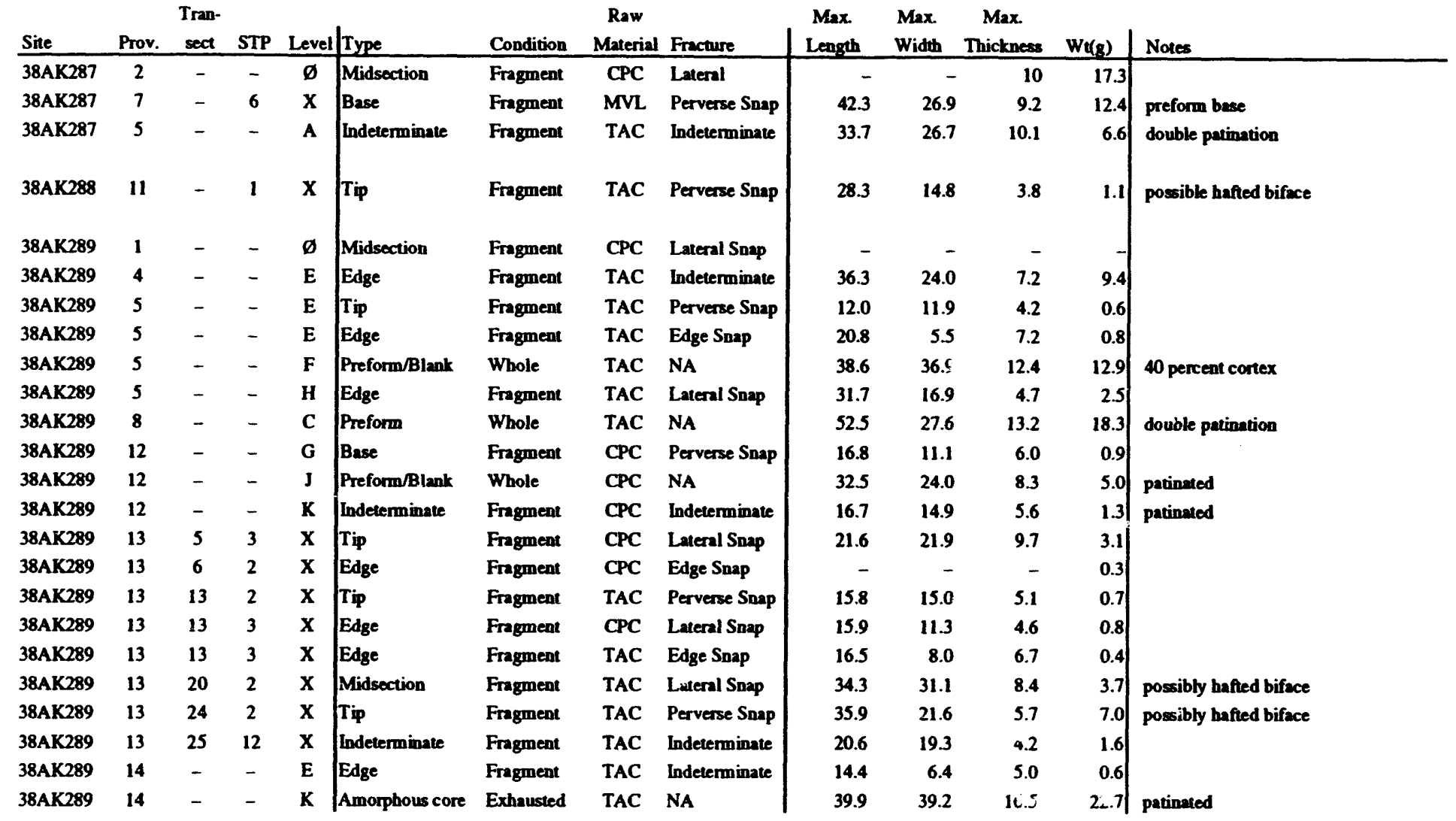

All linear measurements rocorded in millimeters.

Raw Material Codes: CPC=Coastal Plain chert; TAC=Thermally-ahtered Coastal Plain Chert; QTZ=Quartz; MVL=Metavolcanic 
Appendix G. Utilized Flake/Uniface Data.

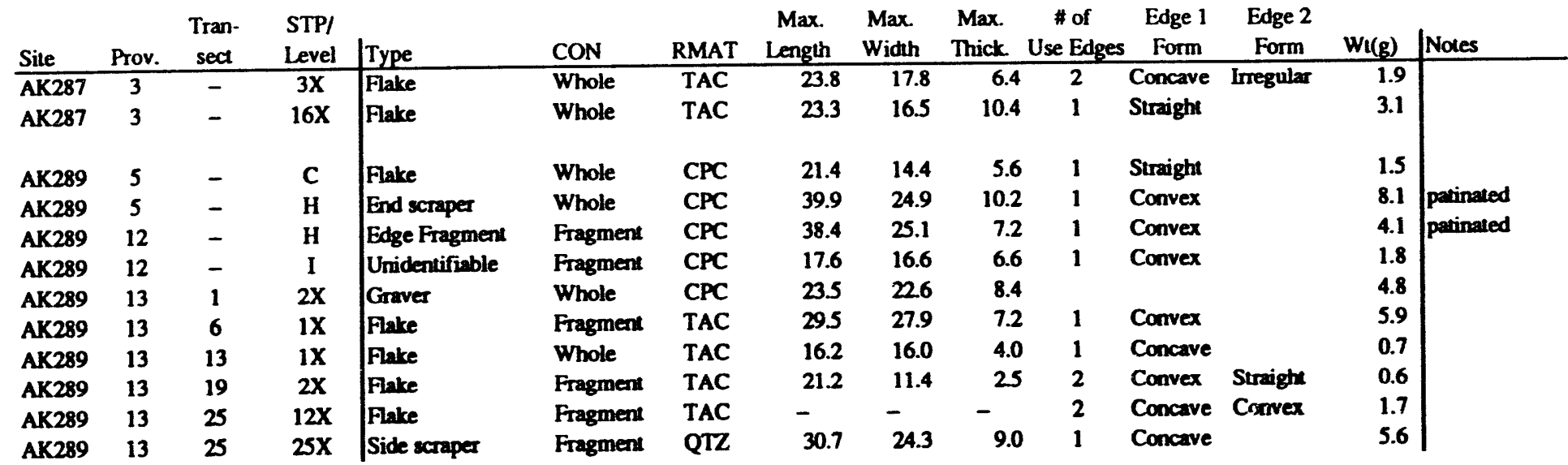


\begin{tabular}{l|lc|l|l|l|l|l} 
Broken & Raw Material \\
Prov. & Broken & Non- & Total & Whole Cortical Size & Whole Noncortical Suze & TA
\end{tabular} Site

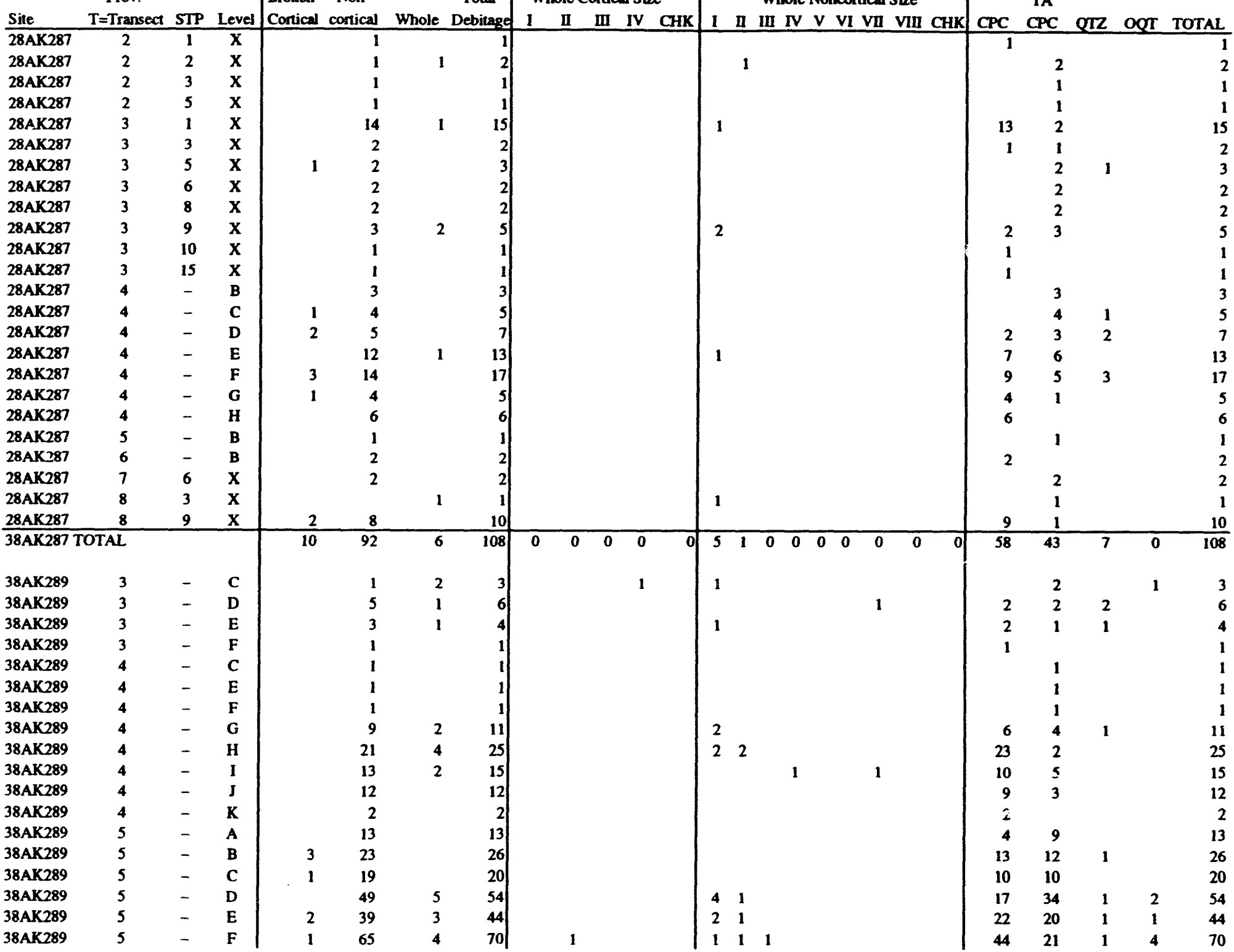




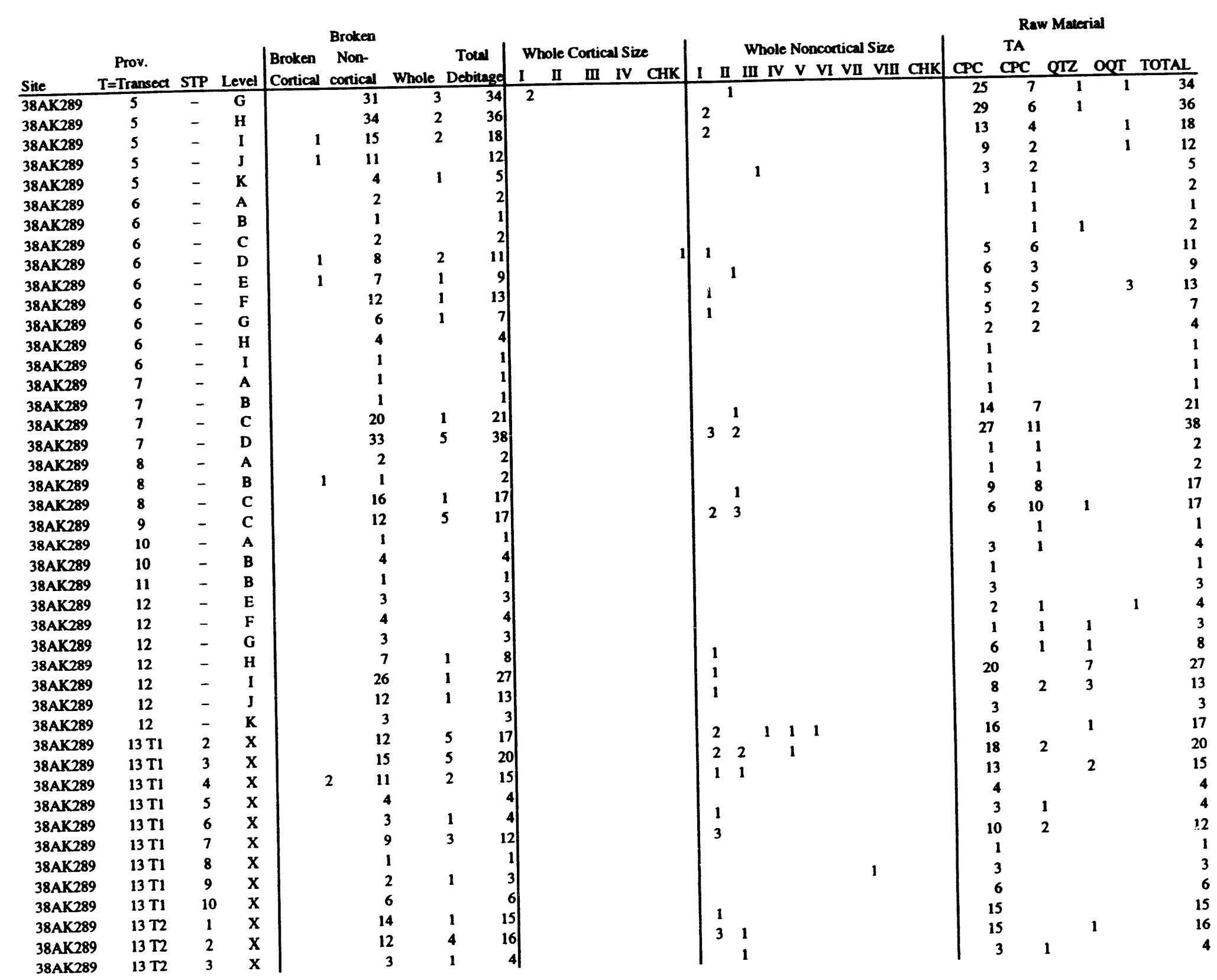




\begin{tabular}{|c|c|c|c|c|c|c|c|c|c|c|c|c|c|c|c|c|c|c|}
\hline \multirow[b]{2}{*}{ Site } & \multirow{2}{*}{$\begin{array}{c}\text { Prov. } \\
\mathrm{T}=\text { Transect }\end{array}$} & \multirow{2}{*}{ STP } & \multirow[b]{2}{*}{ Level } & \multicolumn{4}{|c|}{ Broken } & \multicolumn{2}{|c|}{ Whole Cortical Size } & \multicolumn{4}{|c|}{ Whole Noncortical Size } & \multicolumn{5}{|c|}{ Raw Material } \\
\hline & & & & Contical & contical & Whole & Debiragd & I $\quad$ I & I II IV CHik & 1 & I 1 & III IV $\mathrm{v}$ VI vII & $V_{i}=c H K$ & CPC & CPC & QTZ & $\infty$ & TOTAL \\
\hline 38AK289 & $13 \mathrm{~T} 2$ & 4 & $\mathrm{x}$ & & 3 & 4 & $\begin{array}{ll}4 & 7 \\
\end{array}$ & & & 2 & 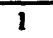 & 1 & & 7 & & & & 7 \\
\hline 38AK289 & $13 \mathrm{~T} 2$ & 6 & $\mathbf{x}$ & & 8 & 1 & 9 & & & 1 & & & & 8 & & 1 & & 9 \\
\hline 38AK289 & $13 \mathrm{~T} 3$ & 2 & $\mathbf{x}$ & & 5 & 2 & 7 & & & 1 & 1 & & & 3 & 3 & & 1 & 7 \\
\hline 38AK289 & $13 T 3$ & 3 & $\mathbf{x}$ & & 1 & 1 & 2 & & & 1 & & & & & 2 & & & 2 \\
\hline 38AK289 & $13 \mathrm{T3}$ & 4 & $\mathbf{x}$ & & 1 & & 1 & & & & & & & 1 & & & & 1 \\
\hline 38AK289 & $13 \mathrm{T3}$ & 5 & $\mathbf{x}$ & & 10 & 1 & 11 & & & & 1 & & & 11 & & & & 11 \\
\hline 38AK289 & $13 \mathrm{~T} 3$ & 6 & $\mathbf{x}$ & & 1 & 1 & 2 & & & & 1 & & & 1 & 1 & & & 2 \\
\hline 38AK289 & $13 \mathrm{T3}$ & 7 & $\mathbf{x}$ & & 3 & & 3 & & & & & & & 3 & & & & 3 \\
\hline 38AK289 & $13 \mathrm{T3}$ & 8 & $\mathbf{x}$ & & 2 & & 2 & & & & & & & 2 & & & & 2 \\
\hline 38AK289 & $13 \mathrm{~T} 3$ & 9 & $\mathbf{x}$ & & 1 & 1 & 2 & 1 & & & & & & 2 & & & & 2 \\
\hline 38AK289 & $13 \mathrm{~T} 3$ & 13 & $\mathbf{x}$ & & 2 & I & 3 & & 1 & & & & & 2 & 1 & & & 3 \\
\hline 38AK289 & $13 \mathrm{~T} 3$ & 14 & $\mathbf{x}$ & & 1 & & 1 & & & & & & & & 1 & & & 1 \\
\hline 38AK289 & $13 \mathrm{~T} 4$ & 2 & $\mathbf{x}$ & 1 & 22 & & 23 & & & & & & & 23 & & & & 23 \\
\hline 38AK289 & $13 \mathrm{~T} 4$ & 3 & $\mathbf{x}$ & & 4 & & 4 & & & & & & & 4 & & & & 4 \\
\hline 38AK289 & $13 \mathrm{~T} 4$ & 4 & $\mathbf{x}$ & & 1 & 1 & 2 & & & & 1 & & & 1 & & 1 & & 2 \\
\hline 38AK289 & $13 \mathrm{~T} 4$ & 5 & $\mathbf{x}$ & & 1 & & 1 & & & & & & & & 1 & & & 1 \\
\hline 38AK2899 & $13 \mathrm{~T} 4$ & 6 & $\mathbf{x}$ & & 5 & & 5 & & & & & & & 5 & & & & 5 \\
\hline 38AK289 & $13 \mathrm{~T} 4$ & 9 & $\mathbf{x}$ & & 2 & & 2 & & & & & & & 2 & & & & 2 \\
\hline 38AK289 & $13 \mathrm{~T} 4$ & 10 & $\mathbf{x}$ & & 7 & 3 & 10 & & & 1 & 2 & & & 10 & & & & 10 \\
\hline 38AK289 & $13 \mathrm{~T} 4$ & 11 & $\mathbf{x}$ & & 1 & & 1 & & & & & & & 1 & & & & 1 \\
\hline 38AK289 & $13 \mathrm{~T} 4$ & 12 & $\mathbf{x}$ & & 1 & 1 & 2 & & & 1 & & & & 1 & 1 & & & 2 \\
\hline 38AK289 & $13 \mathrm{~T} 4$ & 13 & $\mathbf{x}$ & 1 & & & 1) & & & & & & & 1 & & & & 1 \\
\hline 38AK289 & $13 \mathrm{~T} 4$ & 14 & $\mathbf{x}$ & 1 & 9 & 1 & 11 & & & & & 1 & & 6 & 5 & & & 11 \\
\hline 38AK289 & $13 \mathrm{~T} 4$ & 15 & $\mathbf{x}$ & & 7 & 1 & 8 & & & 1 & & & & 3 & 5 & & & 8 \\
\hline 38AK289 & $13 \mathrm{T5}$ & 3 & $\mathbf{x}$ & & 1 & & 1 & & & & & & & & 1 & & & 1 \\
\hline 38AK289 & $13 \mathrm{~T} 5$ & 4 & $\mathbf{x}$ & & 1 & 1 & 2 & & & & & & 1 & 2 & & & & 2 \\
\hline 38AK289 & $13 \mathrm{~T} 5$ & 8 & $\mathbf{x}$ & & 1 & & 1 & & & & & & & 1 & & & & 1 \\
\hline 38AK289 & $13 \mathrm{~T} 5$ & 9 & $\mathbf{x}$ & & 3 & & 3 & & & & & & & 3 & & & & 3 \\
\hline 38AK289 & $13 \mathrm{~T} 5$ & 12 & $\mathbf{x}$ & & 2 & & 2 & & & & & & & 1 & 1 & & & 2 \\
\hline 38AK289 & $13 \mathrm{~T} 6$ & 2 & $\mathbf{x}$ & & 1 & & 1] & & & & & & & 1 & & & & 1 \\
\hline 38AK289 & $13 \mathrm{~T} 6$ & 3 & $\mathbf{x}$ & & 1 & & 1 & & & & & & & & 1 & & & 1 \\
\hline 38AK289 & 13 T6 & 4 & $\mathbf{x}$ & & 2 & & 2 & & & & & & & 1 & & 1 & & 2 \\
\hline 38AK289 & $13 \mathrm{~T} 6$ & 6 & $\mathbf{x}$ & & 5 & 2 & 7 & & & 1 & & 1 & & 7 & & & & 7 \\
\hline 38AK289 & 13 T6 & 12 & $\mathbf{x}$ & & 1 & & 1 & & & & & & & 1 & & & & 1 \\
\hline 38AK289 & 13 T6 & 15 & $\mathbf{x}$ & & 1 & & 1 & & & & & & & 1 & & & & 1 \\
\hline 38AK289 & $13 \mathrm{~T} 7$ & 1 & $\mathbf{x}$ & & 1 & & 1 & & & & & & & 1 & & & & 1 \\
\hline 38AK289 & $13 \mathrm{~T} 7$ & 2 & $\mathbf{x}$ & & 1 & 1 & 2 & & & 1 & & & & 1 & 1 & & & 2 \\
\hline 38AK289 & $13 \mathrm{Tt}$ & 4 & $\mathbf{x}$ & & 2 & & 2 & & & & & & & 2 & & & & 2 \\
\hline 38AK289 & $13 \pi$ & 6 & $\mathbf{x}$ & & 3 & & 3 & & & & & & & 3 & & & & 3 \\
\hline 38AK289 & $13 \mathrm{~T} 7$ & 7 & $\mathbf{x}$ & & 1 & & 1 & & & & & & & & 1 & & & 1 \\
\hline 38AK289 & $13 \mathrm{~T}$ & 9 & $\mathbf{x}$ & & 2 & 3 & 5 & & & 1 & 2 & & & 1 & 1 & & 3 & 5 \\
\hline 38AK289 & $13 \mathrm{~T}$ & 11 & $\mathbf{x}$ & & 4 & 1 & 5 & & & & 1 & & & 4 & & 1 & & 5 \\
\hline 38AK289 & $13 \mathrm{~T} 8$ & 1 & $\mathbf{x}$ & & 2 & & 2 & & & & & & & 1 & 1 & & & 2 \\
\hline 38AK289 & $13 \mathrm{~T} 8$ & 2 & $\mathbf{X}$ & & 6 & 1 & ㄱ) & & & 1 & & & & 4 & 3 & & & 7 \\
\hline
\end{tabular}




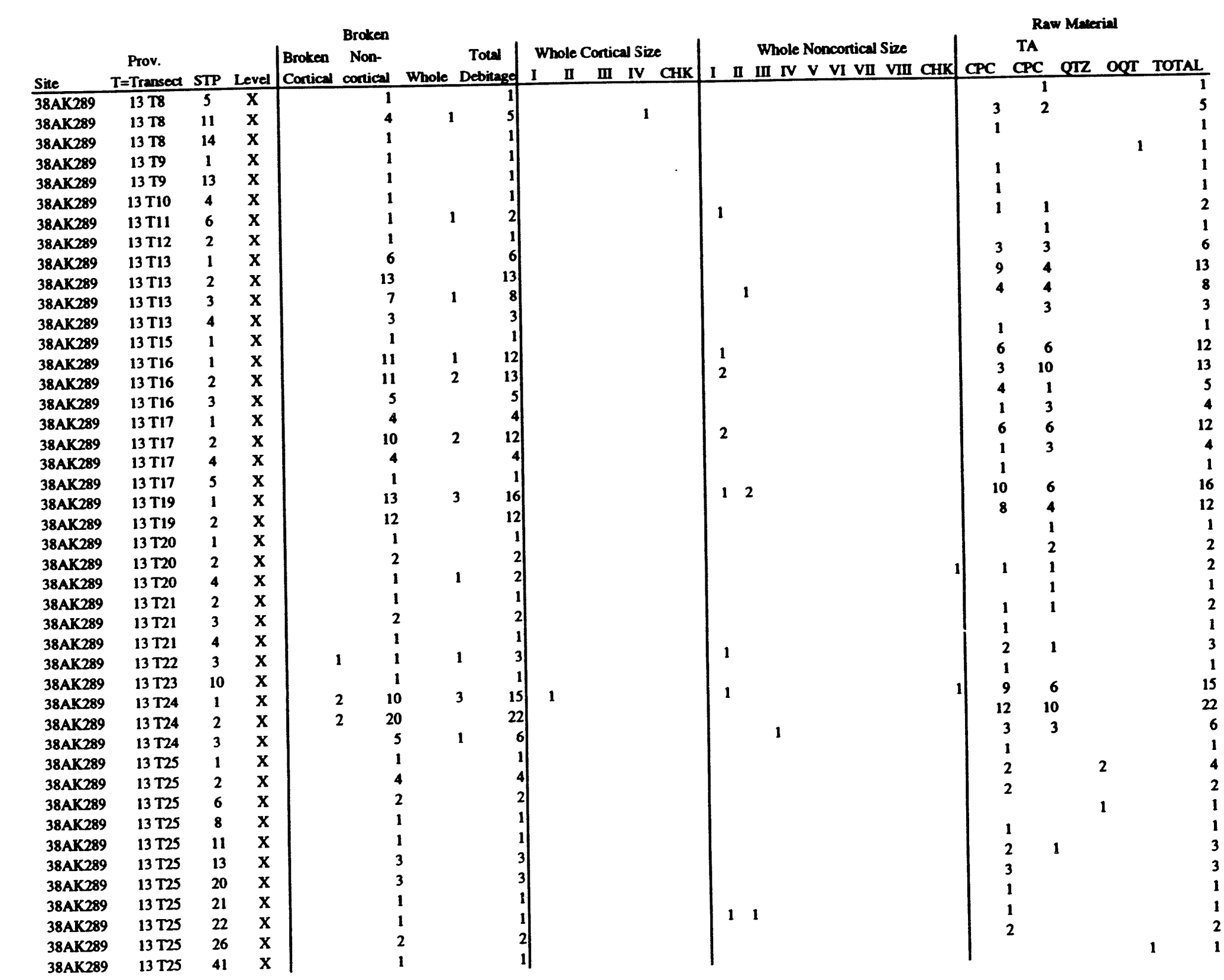




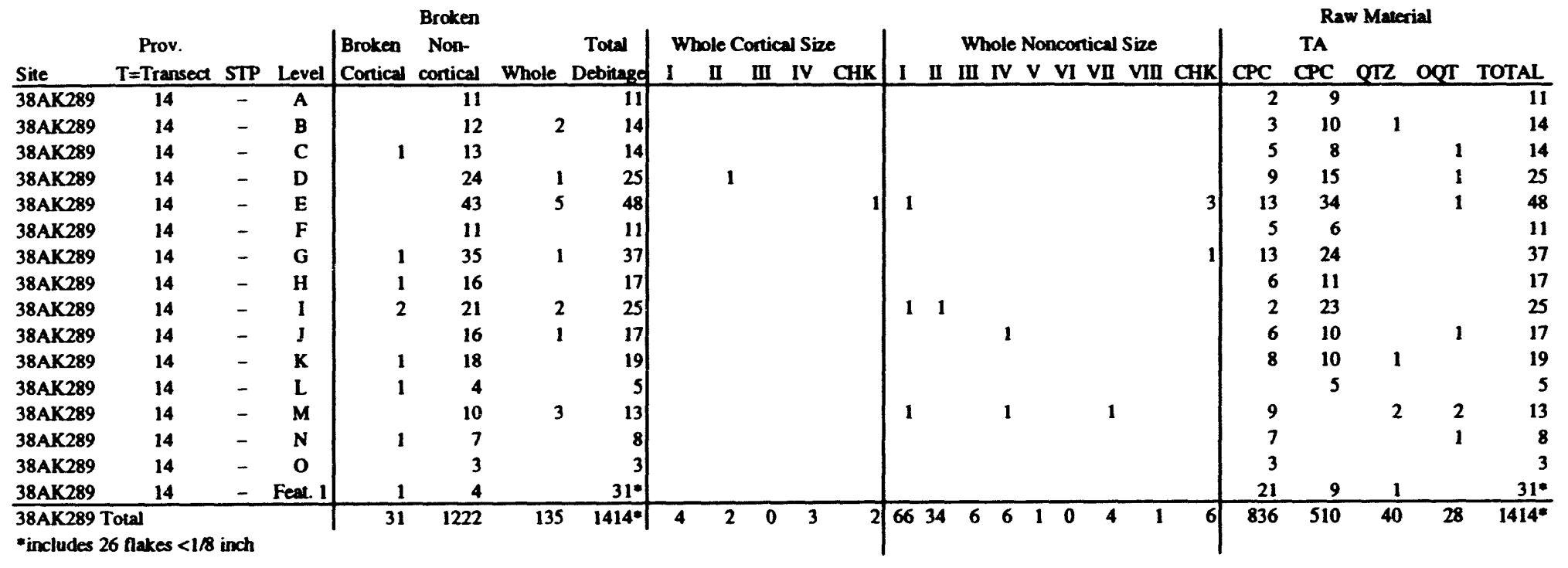




\begin{tabular}{|c|c|c|c|c|c|c|c|c|c|c|c|c|}
\hline Site & Prov. Trans. & Lev. & Cat\# & $\mathbf{N}$ & Material & Class & Subclass & Type & Portion & Bumed & Notes & \\
\hline 38AK287 & 3 & $1 \mathrm{X}$ & 85 & 1 & Metal & Misc. & Metal scrap & & & No & & \\
\hline 38AK287 & 3 & $2 \mathrm{X}$ & 71 & 2 & Ceramic & Architectural & Brick frag. & & & No & & \\
\hline 38 AK287 & 3 & $3 \mathbf{X}$ & 63 & 1 & Glass & Kitchen & Bottle & Soda & Base & No & & \\
\hline 38AK287 & 7 & $3 x$ & 63 & 6 & Glass & Kitchen & Jar & Canning & & No & & \\
\hline 38AK287 & 8 & $4 X$ & 63 & 2 & Glass & Misc. & UID Shard & & & No & & \\
\hline 38AK287 & 8 & $4 X$ & 64 & 1 & Glass & Misc. & UD Shard & & & No & & \\
\hline 38AK287 & 3 & $5 X$ & 63 & 3 & Glass & Misc. & UID Shard & & & No & Brown & \\
\hline 38AK287 & 3 & $5 x$ & 66 & 3 & Glass & Misc. & Flat glass & & & No & & \\
\hline 38AK287 & 8 & $6 \mathbf{X}$ & 52 & 1 & Ceramic & Ceramic & Refined earthenware & Ironstone/whiteware & & No & & \\
\hline 38 AK 287 & 8 & $7 x$ & 66 & 3 & Glass & Misc. & Flat glass & & & No & & \\
\hline 38 AK287 & 8 & $8 \mathrm{X}$ & 63 & 1 & Glass & Misc. & UID Shard & & & No & & \\
\hline 38 AK287 & 5 & A & 19 & 4 & Ceramic & Architectural & Brick frag. & & & No & & \\
\hline 38AK287 & 4 & $\mathbf{A}$ & 52 & 1 & Ceramic & Ceramic & Refined carthenware & Ironstone/whiteware & Flatware base & No & White tinted & \\
\hline 38AK287 & 4 & $\mathbf{A}$ & 52 & 1 & Ceramic & Ceramic & Refined earthenware & Ironstone/whiteware & Cup base & Yes & & - \\
\hline 38 AK287 & 5 & $\mathbf{A}$ & 52 & 1 & Ceramic & Ceramic & Refined earthenware & Ironstone/whiteware & Flatware rim & No & Blue tinted & \\
\hline 38 AK287 & 5 & $\mathbf{A}$ & 52 & 1 & Ceramic & Ceramic & Refined earthenware & Ironstone/whiteware & & No & Blue tinted & \\
\hline 38AK287 & 5 & $\mathbf{A}$ & 52 & 1 & Ceramic & Ceramic & Refined earthenware & Ironstone/whiteware & Cup base & Yes & & \\
\hline 38 AK287 & 4 & $\mathbf{A}$ & 63 & 1 & Glass & Misc. & UID Shard & & & No & Brown & \\
\hline 38AK287 & 4 & $\mathbf{A}$ & 63 & 1 & Glass & Misc. & UID Shard & & & No & Mang. decolored & \\
\hline 38AK287 & 4 & $\mathbf{A}$ & 63 & 1 & Glass & Misc. & UID Shard & & & No & & \\
\hline 38AK287 & 5 & $\mathbf{A}$ & 63 & 1 & Glass & Misc. & UID Shard & & & No & Brown & \\
\hline 38AK287 & 5 & A & 63 & 4 & Glass & Misc. & UID Shard & & & No & & \\
\hline 38AK287 & 6 & A & 63 & 2 & Glass & Misc. & UID Shard & & & No & Brown & \\
\hline 38AK287 & 6 & $\mathbf{A}$ & 63 & 3 & Glass & Misc. & UID Shard & & & No & & \\
\hline 38AK287 & 5 & A & 66 & 4 & Glass & Misc. & Flat glass & & & No & & \\
\hline 38AK287 & 6 & $\mathbf{A}$ & 66 & 1 & Glass & Misc. & Flat glass & & & No & & \\
\hline 38AK287 & 5 & A & 68 & 1 & Metal & Architectural & Nail & Cut & & No & Length $=6.5 \mathrm{~cm}$ & \\
\hline 38AK287 & 6 & A & 71 & 3 & Ceramic & Architectural & Brick frag. & & & No & & \\
\hline 38AK287 & 6 & $\mathbf{A}$ & 72 & 1 & Metal & Misc. & Metal scrap & Poss. ferrule & & No & & \\
\hline 38AK287 & 4 & $\mathbf{A}$ & 84 & 1 & Metal & Misc. & Metal scrap & & & No & & \\
\hline 38AK287 & 4 & A & 84 & 5 & Metal & Misc. & Metal scrap & & & No & & \\
\hline $38 \mathrm{AK} 287$ & 6 & A & 84 & 5 & Metai & Misc. & Metal scrap & Iron & & No & & \\
\hline $38 \mathrm{AK} 287$ & 4 & $\mathbf{A}$ & 85 & 5 & Metal & Misc. & Metal scrap & Iron & & No & & \\
\hline 38 AK287 & 5 & $\mathbf{A}$ & 85 & 5 & Metal & Misc. & Metal scrap & & & No & & \\
\hline 38AK287 & 6 & $\mathbf{A}$ & 85 & 5 & Metal & Misc. & Metal scrap & Irun & & No & & \\
\hline 38AK287 & 5 & A & 87 & 1 & Ebonite & Misc. & Knob & & & No & & \\
\hline 38 AK287 & 5 & B & 52 & 1 & Ceramic & Ceramic & Refined earthenware & Ironstone/whiteware & Flatware rim & No & Blue tinted & \\
\hline 38AK287 & 5 & B & 52 & 2 & Ceramic & Ceramic & Refined earthenware & Ironstone/whiteware & & Yes & & \\
\hline $38 \mathrm{AK} 287$ & 4 & B & 55 & 1 & Ceramic & Ceramic & Stoneware & Alk glz. int/ext. & & No & Green & \\
\hline 38AK287 & 4 & B & 63 & 1 & Glass & Misc. & UID Shard & & & No & Brown & \\
\hline 38AK287 & 4 & B & 63 & 2 & Glass & Misc. & UID Shard & & & No & & \\
\hline $38 \mathrm{AK} 287$ & 5 & B & 63 & 2 & Glass & Misc. & UID Shard & & & No & & \\
\hline 38AK287 & 6 & B & 63 & 1 & Glass & Kitchen & Bottle & Soda & & No & & \\
\hline 38AK287 & 5 & B & 64 & 1 & Glass & Kitchen & Stemware & & Stem & No & Mang. decolored & \\
\hline 38AK287 & 6 & B & 64 & 1 & Glass & Misc. & Flat glass & & & No & & \\
\hline
\end{tabular}




\begin{tabular}{|c|c|c|c|c|c|c|c|c|c|c|c|c|}
\hline Site & Prov. & Trans. & Lev. & Cant & $\mathbf{N}$ & Material & Class & Subclass & Type & Portion & Burned & Noles \\
\hline 38 AK287 & 6 & & 8 & 64 & 1 & Glass & Kitchen & Stemware & & & No & Mang. decolored \\
\hline 38AK287 & 6 & & B & 64 & 1 & Glass & Misc. & UID Shard & & & Yes & Brown \\
\hline 38AK287 & 4 & & B & 66 & 2 & Giass & Misc. & Flat glass & & & No & \\
\hline 38AK287 & 5 & & B & 66 & 3 & Glass & Misc. & Flat glass & & & No & \\
\hline $38 A K 287$ & 5 & & B & 68 & 1 & Metal & Architectural & Nail & Cut & Shaft & No & \\
\hline 38 AK287 & 6 & & B & 68 & 1 & Metal & Architectural & Nail & Cut & Head & No & \\
\hline 38 AK287 & 4 & & B & 71 & 1 & Ceramic & Architectural & Brick frag. & & & No & \\
\hline 38AK287 & 6 & & B & 71 & 3 & Ceramic & Architectural & Brick frag. & & & No & \\
\hline 38AK287 & 4 & & B & 74 & 1 & Metal & Firearm & Shell casing & 0.22 & & No & \\
\hline $38 \wedge K 287$ & 4 & & B & 74 & 1 & Metal & Firearm & Shell casing & 0.45 (cur and crimped) & & No & \\
\hline 38AK287 & 4 & & B & 85 & 5 & Metal & Misc. & Metal scrap & & & No & \\
\hline 38 AK287 & 5 & & B & 85 & 16 & Metal & Misc. & Metal screp & & & No & \\
\hline $38 \mathrm{AK} 287$ & 6 & & B & 85 & 6 & Metal & Misc. & Metal scrap & & & No & \\
\hline $38 A K 287$ & 6 & & B & 85 & 6 & Metal & Misc. & Metal scrap & & & No & \\
\hline 38АK289 & 13 & 2 & $2 \mathrm{X}$ & 49 & 1 & Ceramic & Ceramic & Refined earthenware & Creannware & Marky & No & \\
\hline 38AK289 & 13 & 2 & $3 \mathbf{x}$ & 7 & 2 & Ceramic & Architectural & Brick frag. & & & No & \\
\hline 38AK289 & 13 & 8 & $9 \mathrm{X}$ & 73 & 1 & Metal & Misc. & UID Swivel part & & & No & \\
\hline $38 \mathrm{AK} 289$ & 13 & 11 & PHI & 55 & 1 & Ceramic & Ceramic & Stoneware & Alk glz. ext/fint. & Jar/chumn base & No & Green \\
\hline 38AK289 & 13 & 17 & $2 x$ & 71 & 2 & Ceramic & Architectural & Brick fras. & & & No & \\
\hline 38 AK289 & 13 & 20 & $2 \mathbf{x}$ & 63 & 1 & Glass & Misc. & UID Shard & & & No & Mang. decolored \\
\hline 38 AK289 & 13 & 20 & $4 X$ & 84 & 1 & Metal & Misc. & UID Scrap & & & No & \\
\hline 38 AK289 & 13 & 21 & $2 \mathrm{x}$ & 55 & 1 & Ceramic & Ceramic & Stoneware & Alk. glz. ext. & & No & \\
\hline 38 AK289 & 13 & 23 & $4 X$ & 55 & 1 & Ceramic & Ceramic & Stoneware & Alk glz. ext/nat. slp. int. & Body & No & \\
\hline 38AK289 & 13 & 23 & $5 x$ & 50 & 1 & Ceramic & Ceramic & Refined earthenware & Pearlware & Marky & No & Dark blue transfer print \\
\hline 38AK289 & 13 & 23 & $7 \mathrm{X}$ & 52 & 1 & Ceramic & Ceramic & Refined carthenware & Ironstone/whitewere & Flatware rim & No & Banded green \\
\hline 38AK289 & 13 & 23 & 9X & 55 & 1 & Ceramic & Ceramic & Stoneware & Alk giz. ext. & Strap handle & No & \\
\hline 38AK289 & 13 & 24 & IX & 49 & 1 & Ceramic & Ceramic & Refined earthenware & Creamware & Base & No & \\
\hline 38 AK289 & 13 & 24 & $3 \mathbf{X}$ & 88 & 1 & Botantical & Botentical & Peach pit & & & Yes & \\
\hline 38AK289 & 13 & 25 & $17 X$ & 63 & 1 & Glass & Kitchen & Bottle & & & No & Clear \\
\hline 38AK289 & 13 & & 5 & 49 & 1 & Ceramic & Ceramic & Refined earthenware & Creamware & & No & \\
\hline 38AK289 & 13 & & $3 \mathrm{X}$ & 63 & 1 & Glass & Kitchen & Bottle & & & No & Dark green \\
\hline 38AK289 & 13 & & $3 \mathrm{X}$ & 68 & 1 & Metal & Architectural & Nail & Cut head/cut shank & Head & No & \\
\hline 38 AK289 & 13 & & $4 X$ & 68 & $i$ & Metal & Architectural & Nail & Cut head/cut shank & Head & No & \\
\hline $38 \mathrm{AK} 289$ & 13 & & $4 X$ & 68 & 1 & Metal & Architectural & Nail & Cut shank & Shank & No & \\
\hline 38AK289 & 13 & & $6 \mathrm{X}$ & 68 & 1 & Metal & Architectural & Nail & Cut head/cut shank & Complete & No & Length $=6.5 \mathrm{~cm}$ \\
\hline 38AK289 & 5 & & A & 49 & 1 & Ceramic & Ceramic & Refined earthenware & Creamware & & No & \\
\hline 38AK289 & 5 & & A & 49 & 1 & Ceramic & Ceramic & Refined earthenware & Creamware & & No & \\
\hline 38AK289 & 14 & & A & 49 & 1 & Ceramic & Ceramic & Refined earthenware & Creamware & & No & \\
\hline 38AK289 & 14 & & A & 51 & 1 & Ceramic & Ceramic & Refined earthenware & Pearlware & & No & \\
\hline 38AK289 & 14 & & A & 55 & 1 & Ceramic & Ceramic & Stoneware & Alk glz. ext/int. & Body & No & \\
\hline 38 AK289 & 5 & & A & 60 & 1 & Ceramic & Ceramic & Coarse earthenware & Colonoware & Body & No & \\
\hline 38AK289 & 5 & & A & 64 & 1 & Glass & Misc. & Flat glass & & & No & Clear \\
\hline 38AK289 & 5 & & A & 68 & 1 & Metal & Architectural & Nail & Wrought head and shank & Head & No & - \\
\hline 38AX289 & 14 & & A & 68 & 1 & Metal & Architectural & Nail & Wrought head and shank & Head & No & \\
\hline 38AK289 & 11 & & A & 69 & 1 & Metal & Architectural & Nail & Wire & & No & Length $=6.5 \mathrm{~cm}$ \\
\hline
\end{tabular}

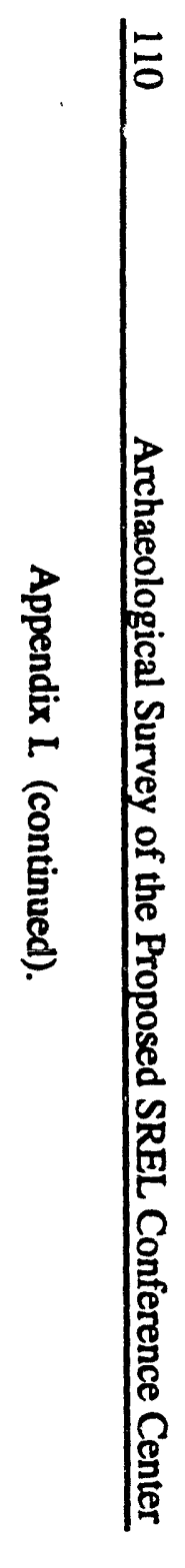




\begin{tabular}{|c|c|c|c|c|c|c|c|c|c|c|c|c|}
\hline Site & Prov. & Trans. & Lev. & Call & $\mathbf{N}$ & Material & Class & Subclass & Type & Portion & Burned & Notes \\
\hline $38 \mathrm{AK} 287$ & 6 & & B & 64 & 1 & Glass & Kitchen & Stemware & & & No & Mang. decolored \\
\hline 38AK287 & 6 & & B & 64 & 1 & Glass & Misc. & UID Shard & & & Yes & Brown \\
\hline 38 AK287 & 4 & & B & 66 & 2 & Glass & Misc. & Flat glass & & & No & \\
\hline $38 A K 287$ & 5 & & B & 66 & 3 & Glass & Misc. & Flat glass & & & No & \\
\hline 38AK287 & 5 & & B & 68 & 1 & Metal & Architectural & Nail & Cut & Shaft & No & \\
\hline 38AK287 & 6 & & B & 68 & 1 & Metal & Architectural & Nail & Cut & Head & No & \\
\hline 38AK287 & 4 & & B & 71 & 1 & Ceramic & Architectural & Brick frag. & & & No & \\
\hline 38AK287 & 6 & & B & 71 & 3 & Ceramic & Architectural & Brick frag. & & & No & \\
\hline 38AK287 & 4 & & B & 74 & 1 & Metal & Firearm & Shell casing & 0.22 & & No & \\
\hline 38AK287 & 4 & & B & 74 & 1 & Metal & Firearm & Shell casing & 0.45 (cut and crimped) & & No & \\
\hline 38 AK287 & 4 & & B & 85 & 5 & Metal & Misc. & Metal scrap & & & No & \\
\hline 38 AK287 & 5 & & B & 85 & 16 & Metal & Misc. & Metal scrap & & & No & \\
\hline 38 AK 287 & 6 & & B & 85 & 6 & Metal & Misc. & Metal scrap & & & No & \\
\hline 38 AK287 & 6 & & $\mathbf{B}$ & 85 & 6 & Metal & Misc. & Metal scrap & & & No & \\
\hline 38 AK289 & 12 & 2 & $2 x$ & 49 & 1 & Ceramic & Ceramic & Refined earthenware & Creamware & Marky & No & \\
\hline $38 A K 289$ & 13 & 2 & $3 \mathbf{x}$ & 7 & 2 & Ceramic & Architectural & Brick frag. & & & No & \\
\hline 38AK289 & 13 & 8 & $9 x$ & 73 & 1 & Metal & Misc. & UID Swivel part & & & No & \\
\hline 38 AK289 & 13 & 11 & PHI & 55 & 1 & Ceramic & Ceramic & Stoneware & Alk glz. ext/int. & Jar/churm base & No & Green \\
\hline 38 AK289 & 13 & 17 & $2 x$ & 71 & 2 & Ceramic & Architectury & Brick frag. & & & No & \\
\hline 38 AK289 & 13 & 20 & $2 \mathrm{x}$ & 63 & 1 & Glase & Misc. & UID Shard & & & No & Mang. decolored \\
\hline 38AK289 & 13 & 20 & $4 \mathrm{X}$ & 84 & 1 & Metal & Misc. & UID Scrap & & & No & \\
\hline 38AK289 & 13 & 21 & $2 \mathrm{X}$ & 55 & 1 & Ceramic & Ceramic & Stoneware & Alk. glz. ext. & & No & \\
\hline 38 AK289 & 13 & 23 & $4 X$ & 55 & 1 & Ceramic & Ceramic & Stoneware & Alk. glz. ext/nat. slp. int. & Body & No & \\
\hline 38 AK289 & 13 & 23 & $\mathbf{s X}$ & 50 & $i$ & Ceramic & Ceramic & Refined carthenware & Pearlware & Marley & No & Dark blue transfer print \\
\hline 38AK289 & 13 & 23 & $7 X$ & 52 & 1 & Ceramic & Ceramic & Refined earthenware & Ironstone/whiteware & Flatware rim & No & Banded green \\
\hline 38AK289 & 13 & 23 & $9 X$ & 55 & 1 & Ceramic & Ceramic & Stoneware & Alk glz. ext. & Strap handle & No & \\
\hline 38AK289 & 13 & 24 & $\mathbf{I X}$ & 49 & 1 & Ceramic & Ceramic & Refined earthenware & Greamware & Base & No & \\
\hline 38AK289 & 13 & 24 & $3 \mathbf{X}$ & 88 & 1 & Botantical & Botantical & Peach pit & & & Yes & \\
\hline 38 AK289 & 13 & 25 & $17 X$ & 63 & 1 & Glass & Kitchen & Bottle & & & No & Clear \\
\hline 38AK289 & 13 & & 5 & 49 & 1 & Ceramic & Ceramic & Refined earthenware & Creamware & & No & \\
\hline 38AK289 & 13 & & $3 \mathbf{X}$ & 63 & 1 & Glass & Kitchen & Bottle & & & No & Dark green \\
\hline 38 AK289 & 13 & & $3 \mathbf{X}$ & 68 & 1 & Metal & Architectural & Nail & Cut head/cut shank & Head & No & \\
\hline 38AK289 & 13 & & $4 X$ & 68 & 1 & Metal & Architectural & Nail & Cut head/cut shank & Head & No & \\
\hline 38 AK289 & 13 & & $4 \mathrm{X}$ & 68 & $i$ & Metal & Architectural & Nail & Cut shank & Shank & No & \\
\hline 38 AK2289 & 13 & & $6 \mathrm{X}$ & 68 & 1 & Metal & Architectural & Nail & Cut head/cut shank & Complete & No & Length $=6.5 \mathrm{~cm}$ \\
\hline 38AK289 & 5 & & A & 49 & 1 & Ceramic & Ceramic & Refined earthenware & Creamware & & No & \\
\hline 38 AK289 & 5 & & A & 49 & 1 & Ceramic & Ceramic & Refined earthenware & Creamware & & No & \\
\hline 38AK289 & 14 & & A & 49 & 1 & Ceramic & Ceramic & Refined earthenware & Creanware & & No & \\
\hline 38AK289 & 14 & & A & 51 & 1 & Ceramic & Ceramic & Refined earthenware & Peariware & & No & \\
\hline 38AK289 & 14 & & A & 55 & 1 & Ceramic & Ceramic & Stoneware & Alk glz. ext/int. & Body & No & \\
\hline 38AK289 & 5 & & A & 60 & 1 & Ceramic & Ceramic & Coarse earthenware & Colonoware & Body & No & \\
\hline 38AK289 & 5 & & A & 64 & $i$ & Glass & Misc. & Flat glass & & & No & Clear \\
\hline 38 AK 289 & 5 & & A & 68 & 1 & Metal & Architectural & Nail & Wrought head and shank & Head & No & \\
\hline 38AK289 & 14 & & A & 68 & 1 & Metal & Architectural & Nail & Wrought head and shank & Head & No & \\
\hline 38AK289 & 11 & & $\mathbf{A}$ & 69 & 1 & Metal & Architectural & Nail & Wire & & No & Length $=6.5 \mathrm{~cm}$ \\
\hline
\end{tabular}




\begin{tabular}{|c|c|c|c|c|c|c|c|c|c|c|c|}
\hline Site & Prov. Trans. & Lev. & Catl & $\mathbf{N}$ & Material & Class & Subclass & Type & Portion & Burned & Notes \\
\hline 38AK289 & 7 & A & 71 & 17 & Misc. & Architectural & Mortar & & & No & \\
\hline $\begin{array}{l}\text { 38AK289 } \\
\text { 38AK289 }\end{array}$ & 14 & $\mathbf{A}$ & 71 & 4 & Ceramic & Architectural & Brick frag. & & & No & \\
\hline 38AK289 & 14 & $\mathbf{A}$ & 71 & 1 & Misc. & Architectural & Mortar & & & No & \\
\hline $\begin{array}{l}38 \text { AK289 } \\
38 \text { AK } 289\end{array}$ & 14 & B & 49 & 1 & Ceramic & Ceramic & Refined earthenware & Creamware & Plate rim & No & \\
\hline 38AK289 & 14 & B & 49 & 1 & Ceramic & Ceramic & Refined earthenware & Creamware & & No & \\
\hline 38AK289 & 14 & B & 50 & 1 & Ceramic & Ceramic & Refined earthenware & Pearlware & Bowl rim & No & Handpainted fineline\&do/banded \\
\hline 38AK289 & 5 & B & 63 & 1 & Glass & Kitchen & Bottle & & & No & Dark green \\
\hline 38AK289 & 14 & B & 63 & 1 & Glass & Misc. & UID Shard & & & No & Mang. decolored \\
\hline 38AK289 & 5 & B & 68 & 1 & Metal & Aschitectural & Nail & Cut head/cut shank & Complete & No & Length $=8.0 \mathrm{~cm}$ \\
\hline 38AK289 & 5 & B & 68 & 1 & Metal & Architectural & Nail & Wrought head/cut shank & Head & No & \\
\hline 38 AK289 & 7 & B & 71 & 4 & Ceramic & Architectural & Brick frag. & & & No & \\
\hline 38AK289 & 5 & B & 85 & 1 & Metal & Misc. & Scrap & & & No & \\
\hline 38AK289 & 14 & B & 85 & 1 & Metal & Misc. & Metal scrap & & & No & \\
\hline 38AK466 & 1 & $\emptyset$ & 52 & 1 & Ceramic & Ceramic & Refined carthenware & Ironstone/whiteware & $\operatorname{Rim}$ & No & Blue tinted \\
\hline 38AK466 & 1 & $\emptyset$ & 52 & 2 & Ceramic & Ceramic & Refined earthenware & Ironstone/whiteware & $\operatorname{Rim}$ & No & \\
\hline $38 \mathrm{AK} 466$ & 1 & $\emptyset$ & 52 & 1 & Ceramic & Ceramic & Refined earthenware & Ironstone/whiteware & Tescup base & No & \\
\hline 38AK466 & 1 & $\emptyset$ & 52 & 2 & Ceramic & Ceramic & Refined earthenware & Ironstone/ whiteware & & No & Blue tinted \\
\hline 38AK466 & $i$ & 0 & 52 & 3 & Ceramic & Ceramic & Refined earthenware & Ironstone/whiteware & & No & \\
\hline $38 A K 466$ & 1 & $\emptyset$ & 53 & 1 & Ceramic & Ceramic & Refined earthenware & Ironstone/whiteware & Tescup handle & No & Embossed \\
\hline 38AK466 & 1 & $\varnothing$ & 61 & 1 & Ceramie & Ceramic & Coarse earthenware & Henty cup for pine gum & Base/wall & No & \\
\hline 38AK466 & 1 & $\bar{\emptyset}$ & 63 & 2 & Glass & Kitchen & Canning jar & & & No & \\
\hline 38AK466 & 1 & $\emptyset$ & 64 & 1 & Glass & Kitchen & Can. jar cap liner & & & No & \\
\hline $38 \mathrm{AK} 466$ & 1 & $\emptyset$ & 73 & 1 & Metal & Misc. & Unident. & & & & \\
\hline
\end{tabular}



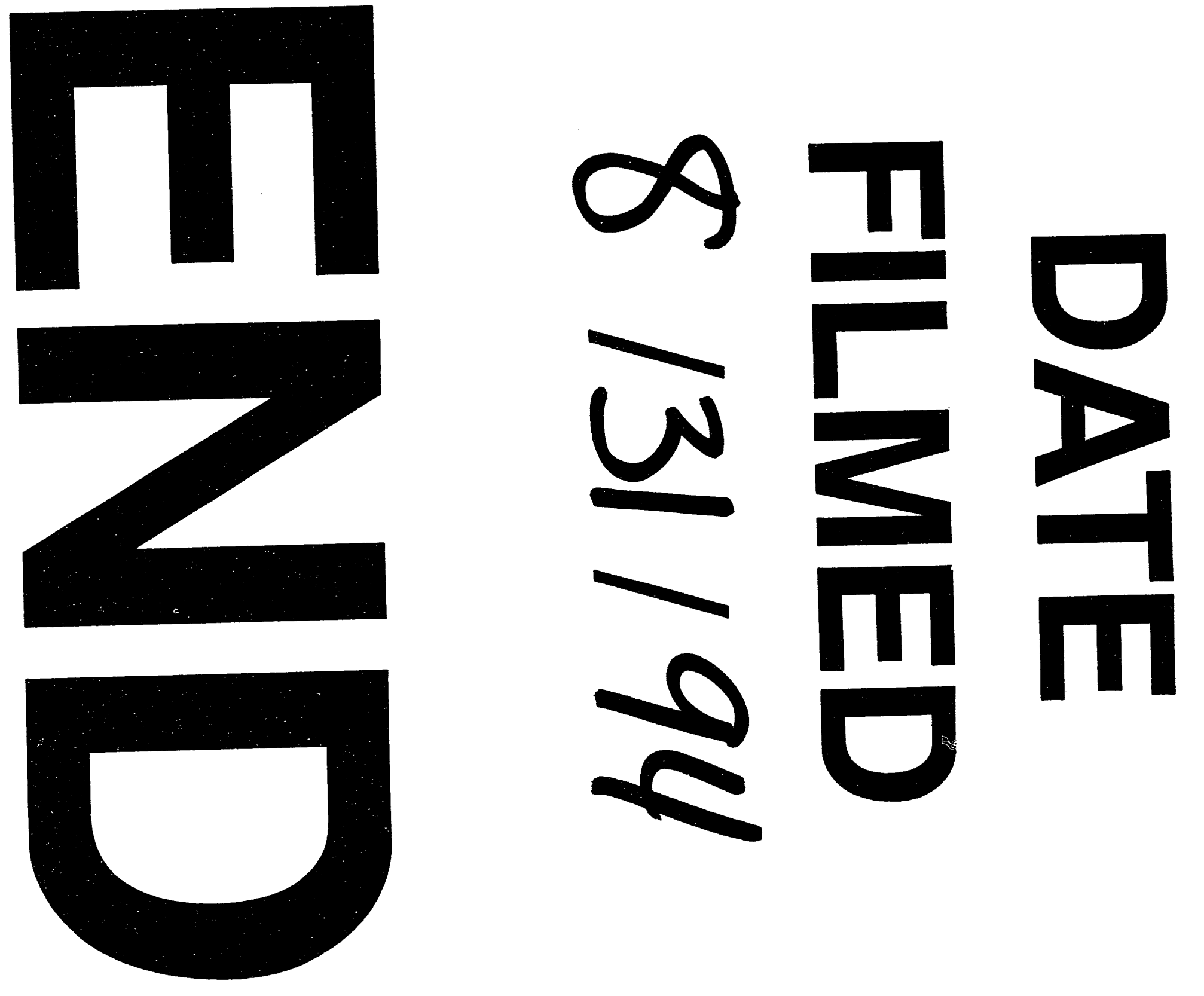
